\title{
A JUDICIALIZAÇÃO DA POLÍTICA: \\ O PODER JUDICIÁRIO E A DEFINIÇÃO DE POLÍTICAS NACIONAIS
}

DISSERTAÇÃO DE MESTRADO

Prof. Dr. José Levi Mello do Amaral Júnior

Orientador

Faculdade de Direito da Universidade de São Paulo

São Paulo 


\section{A JUDICIALIZAÇÃO DA POLÍTICA: O PODER JUDICIÁRIO E A DEFINIÇÃO DE POLÍTICAS NACIONAIS}

Dissertação apresentada junto ao Departamento de Direito do Estado da Faculdade de Direito da Universidade de São Paulo, como requisito parcial para a obtenção do título de Mestre em Direito do Estado.

Área de concentração: Direito Constitucional.

Orientador: Prof. Dr. José Levi Mello do Amaral Júnior.

Faculdade de Direito da Universidade de São Paulo São Paulo 


\section{A JUDICIALIZAÇÃO DA POLÍTICA: \\ O PODER JUDICIÁRIO E A DEFINIÇÃO DE POLÍTICAS NACIONAIS}

Dissertação apresentada junto ao Departamento de Direito do Estado da Faculdade de Direito da Universidade de São Paulo, como requisito parcial para a obtenção do título de Mestre em Direito do Estado, na área de concentração de Direito Constitucional.

Examinado em: de de 2014

Resultado:

Banca Examinadora

Prof. Dr. José Levi Mello do Amaral Júnior 


\section{AGRADECIMENTOS}

Em primeiro lugar, ao meu orientador, José Levi Mello do Amaral Júnior, pelos constantes e valiosos ensinamentos, pela confiança e por ter me proporcionado participar uma vez mais da vida acadêmica da Faculdade de Direito do Largo de São Francisco.

Aos amigos do escritório Marques Rosado, Toledo Cesar \& Carmona Advogados, Ligia Miranda, Patrick Lobo, Guilherme Quintana, José Machado, Carlos Elias, Bruno Batista, Marcelo Junqueira e Gustavo Ramos, pelo apoio, pela compreensão, e por fazerem de meu ambiente de trabalho uma segunda casa. Em especial, agradeço à Denise Martins, pelo imenso carinho, e ao Professor Carlos Alberto Carmona, a quem tanto admiro, pela generosidade e pela aprendizagem diária que me proporciona.

A Telma Lisowski e Renata Villela, pelo companheirismo em todos os momentos.

A Carolina Gattolin e Carolina Bellinger, pela cumplicidade e pelas incontáveis gargalhadas.

A Gabriela Kazue, Carolina Pugliesi e João Eberhardt, pelos momentos de convivência, pelos conselhos, pela paciência, em suma, pela amizade.

Mais importante, agradeço à minha mãe, Teresa, à minha irmã, Marina, e ao meu avô, José Guarany, pelo amor incondicional e pelo apoio de sempre. A eles, e à memória de meu pai, dedico este trabalho. 


\section{RESUMO}

DI VECCHIA NETO, Berardino. A judicialização da política: o Poder Judiciário e a definição de políticas nacionais. 2014. 158f. Dissertação (Mestrado) - Faculdade de Direito, Universidade de São Paulo, São Paulo, 2014.

O papel desempenhado pelo Poder Judiciário nos mais diversos Estados passa por sensível evolução ao longo do século XX, à medida que se desenvolveram os sistemas de controle de constitucionalidade. De um lado, os atores políticos assumem especial importância nesse processo. Os modelos de revisão judicial foram reforçados, no mais das vezes, em paralelo à positivação, em âmbito constitucional, de um amplo rol de direitos fundamentais e de princípios balizadores e limitadores do poder estatal. Com isso, os elementos cotejados no processo legislativo de tomada de decisões políticas são revestidos de status constitucional e transportados para o discurso argumentativo do Direito, o que leva a um processo de judicialização da Política que permite que a atividade legiferante seja passível de confronto perante instâncias judiciárias. Os instrumentos de controle de constitucionalidade assumem, assim, novos contornos, permitindo que o Judiciário interfira no conteúdo das escolhas políticas feitas pela maioria governante. De outro lado, o Poder Judiciário - particularmente as Cortes Constitucionais - passa a assumir a corresponsabilidade na efetivação das metas e compromissos estatais, com o que desenvolve uma política institucional mais proativa e comprometida com a concretização substancial de valores democráticos, interferindo, assim, de maneira mais incisiva e rígida no controle do processo político. A definição de políticas fundamentais e o processo legiferante passam a contar com constante participação do Judiciário. $\mathrm{Na}$ realidade brasileira, a Constituição de 1988 amplia as competência do Supremo Tribunal Federal em sede de controle de constitucionalidade, inserindo o órgão de maneira efetiva nesse contexto de intervenção judicial na Política. A última década, por sua vez, marcou uma perceptível mudança em sua atividade e em sua interferência no processo de tomada de decisões políticas pelos demais Poderes. Valendo-se dos diversos instrumentos de controle que lhe são disponibilizados, assumiu o compromisso de participar na efetivação dos preceitos constitucionais pátrios mediante a revisão do conteúdo normativo decorrente das escolhas políticas tomadas em outras instâncias. Desse modo, tornou-se verdadeiro copartícipe do processo de definição de políticas legislativas nacionais, seja rechaçando normas que repute inconstitucionais, seja proferindo decisões com claros efeitos normativos que buscam readequar e conformar as escolhas dos atores políticos. Nesse processo decisório, entra em jogo a intensidade com que a Corte busca impor sua visão e suas concepções no tocante à efetivação e concretização dos compromissos constitucionais. A sobreposição de ponderações judiciais e legislativas acarreta, a seu turno, importantes efeitos sistêmicos ao diálogo interinstitucional que se desenvolve entre os Poderes, em especial no que concerne à distribuição das funções estatais dentro das premissas democráticas e ao dimensionamento do papel que compete a cada um dos Poderes no processo de efetivação e proteção da Constituição.

Palavras-chave: Cortes Constitucionais. Supremo Tribunal Federal. Controle de constitucionalidade. Definição de políticas nacionais. 


\begin{abstract}
DI VECCHIA NETO, Berardino. The judicialization of politics: the Judiciary in the national policy-making. 2014. 158p. Master Degree Thesis - Faculty of Law, University of São Paulo, São Paulo, 2014.

The role played by the Judiciary Branch in the several different States has undergone a sensible evolution throughout the $20^{\text {th }}$ century to the extent that the judicial review systems develop. On the one side, the political actors assume special importance in this process. The models of judicial review have been reinforced, often times, in parallel with the enactment, in the constitutional level, of an ample list of fundamental rights and principles governing and limiting the state power. Therefore, the elements collated in the legislative process of taking political decisions are vested with constitutional status and transported to the argumentative discourse of Law, which leads to a process of judicialization of politics that allows the legislative activity to be subject to confrontation with judiciary instances. The instruments of judicial review assume, therefore, new contours allowing the Judiciary to interfere in the content of the political choices made by the governing majority. On the other side, the Judiciary Branch, and particularly the Constitutional Courts, begins to assume the co-responsibility in the effectiveness of the state goals and undertakings, resulting in the development of an institutional policy more proactive and committed to the substantial concretization of democratic values, thus interfering, in a more incisive and rigid manner, in the control of the political process. The definition of fundamental policies and the lawmaking process start to count with the participation of the Judiciary. In the Brazilian reality, the 1988 Constitution has enlarged the competence of the Brazilian Supreme Court in matters of judicial review, inserting this organ in an effective manner in the context of judicial intervention in politics. The last decade, in turn, has marked a perceptible change in its activity and in its interference in the process of decision-making political decisions by the remainder Branches of the State. By using the diverse instruments of control available to it, it has assumed the undertaking to participate in the effectiveness of the national constitutional principles by means of the review of the normative content arising from the political choices made in other instances. Therefore, it has become a true co-participant in the process of defining national legislative policy, be it by rejecting norms which it reputes unconstitutional, or by enacting decisions with clear normative effects that seek to realign and conform the choices of the political actors. In this decision-making process, comes into play the intensity with which the Court seeks to impose its view and its conceptions regarding the effectiveness and concretization of the constitutional undertakings. The overlap of judicial and legislative considerations triggers, in its turn, important systemic effects in the inter-institutions dialogue developing among the Branches, particularly with regard to the distribution of the state functions within the democratic premises and the dimension of the role played by each Branch in the effectiveness and protection of the Constitution.
\end{abstract}

Key words: Constitutional Courts. Brazilian Supreme Court. Judicial Review. National policy-making. 


\section{SUMÁRIO}

INTRODUÇÃO

\section{O JUDICIÁRIO E A DEFINIÇÃO DE DECISÕES POLÍTICAS FUNDAMENTAIS...13}

1.1 O surgimento e o desenvolvimento do controle de constitucionalidade: causas institucionais .18

1.1.1 Premissa teórica: a supremacia da Constituição 19

1.1.2 O século XX e a transformação nos paradigmas constitucionais e estatais. ........23

1.1.3 A desneutralização do Poder Judiciário e a proteção de pré-compromissos.........31

1.2 Os atores políticos e a expansão da atuação política do Judiciário...................................35

1.2.1 Fatores históricos: traumas do passado e reafirmação do compromisso democrático.

1.2.2 O controle de constitucionalidade como 'seguro político' e como instrumento da hegemonia dominante 41

1.2.3 A deferência de questões políticas controversas . 45

1.3 O Judiciário na arena política. 47

1.3.1 A relevância da política institucional do Judiciário.. 48

1.3.2 A reação dos atores políticos à expansão das Cortes Constitucionais. 52

1.3.3 A definição de políticas legislativas pelo Judiciário: experiências estrangeiras .57

2. O SUPREMO TRIBUNAL FEDERAL NA ARENA POLÍTICA.

2.1 A Constituição de 1988 e a expansão da influência política do Supremo Tribunal Federal

2.1.1 Alguns apontamentos sobre a dimensão política do sistema de controle de constitucionalidade brasileiro

2.1.2 Os mecanismos de intervenção do Supremo Tribunal Federal na definição de políticas nacionais

2.1.3 Mudanças na política institucional do Supremo Tribunal Federal e o surgimento de um novo escopo de atuação.

2.2 A definição de políticas legislativas pelo Supremo Tribunal Federal......................92

2.2.1 A natureza das questões políticas submetidas à Corte..............................................92

2.2.2 Análise de casos relevantes 96 


\section{EFEITOS SISTÊMICOS DA ATUAÇÃO POLÍTICA DO SUPREMO TRIBUNAL}

FEDERAL

3.1 Executivo e Legislativo no contexto da expansão do Supremo Tribunal Federal... 110

3.1.1 A reação dos demais Poderes à interferência política do Supremo Tribunal Federal

3.1.2 A nomeação dos Ministros e o papel contramajoritário do Supremo Tribunal Federal

3.2 A ampliação pretoriana do regramento constitucional: a ratio decidendi das decisões do Supremo Tribunal Federal e a liberdade do legislador.

3.2.1 Entre o ativismo judicial e a autocontenção: a autorreferenciabilidade de competências como questão crucial.

3.3 Controle de constitucionalidade e democracia.

CONCLUSÃO 


\section{INTRODUÇÃO}

Os compromissos democráticos assumidos pelos mais diversos Estados ao longo do século passado - os quais refletem uma nova concepção acerca dos limites a serem impostos ao exercício do poder estatal - os colocaram diante de um desafio, qual seja, garantir a efetividade de suas Constituições. A disseminação da previsão de balizas aplicáveis ao processo de tomada de decisões políticas, em especial pela constitucionalização de direitos e garantias fundamentais e de princípios que informam cada sistema jurídico, impôs, assim, a necessidade de se desenvolver e reforçar mecanismos que permitissem o controle da produção normativa. Embora a democracia inclua o direito da maioria de, mediante representantes eleitos, fazer escolhas políticas, que se convertem em normas que regulamentam a vida em sociedade e são aplicáveis a toda a coletividade, envolve também o resguardo e a proteção de um núcleo essencial de direitos e valores previstos nas Constituições, que não podem ser tolhidos pela maioria sem prejuízo às próprias premissas democráticas.

Os temores em se relegar exclusivamente aos atores políticos o controle do processo de escolhas políticas fizeram prosperar e desenvolver a ideia de se atribuir a função de controle normativo também ao Poder Judiciário, visto como instituição neutra do ponto de vista do jogo político-partidário e apta, portanto, à fiscalização da atividade legiferante. Com base na mesma premissa em que já se desenvolvia a atividade da Suprema Corte dos Estados Unidos, no sentido de negar aplicabilidade a normas que fossem reputadas contrárias à Constituição, como corolário da necessidade de se resguardar sua supremacia na ordem jurídica vigente, houve ampla disseminação de Constituições que dotavam os Judiciários nacionais de poderes de controle, com o que se desenvolveu uma verdadeira jurisdição constitucional.

Esse processo se desenvolve, sobretudo, no contexto de expansão do modelo de Welfare State, que demandava uma intervenção estatal no sentido de garantir uma igualdade real entre os indivíduos - e, com isso, exigia um fazer dos Estados -, bem como de superar de regimes antidemocráticos. Em razão disso, por um lado passou-se a entender que os valores e premissas insculpidos explícita ou implicitamente nas Constituições representavam não só verdadeiras metas a serem realizadas por meio da atividade estatal como também limites a serem respeitados pelo legislador; por outro lado, passou-se a exigir o exercício de um controle normativo que voltasse sua atenção igualmente ao 
conteúdo das escolhas políticas, no sentido de tutelar, tanto quanto possível, o respeito a um núcleo material dos direitos constitucionalizados.

O papel a ser exercido pelo Poder Judiciário no contexto da divisão das funções do Estado, com isso, adquire nova relevância. Para além de aplicar a lei na resolução de conflitos interindividuais, assume também o dever de aplicar a Constituição no controle da atividade estatal, de modo a garantir sua efetividade, com o que assume a função de declarar inconstitucionais todos os atos contrários à Constituição - rechaçando-os do ordenamento.

Decorre daí um processo intenso de judicialização da Política, na medida em que as decisões das maiorias governantes são passíveis de serem confrontadas perante as instâncias judiciais, mediante o manejo de preceitos constitucionalizados. A ingerência do Poder Judiciário na fiscalização das escolhas políticas torna-se constante. Muito embora isso seja fomentado pela ampliação do escopo e da abrangência das Constituições, que multiplicam os paradigmas de controle e fazem com que conceitos políticos sejam revestidos de juridicidade, o fato de esse processo ser verificado também em Estados com Constituições menos profusas em positivação de direitos fundamentais e princípios políticos mostra que o desenvolvimento da jurisdição constitucional está também atrelado à própria função que o Judiciário encara desempenhar.

Nesse sentido, a política institucional dos Judiciários nacionais, em especial de suas Cortes Constitucionais, sofre sensíveis modificações. Paulatinamente, verifica-se que assumem o desígnio de corrigir eventuais falhas do processo de tomada de decisões políticas. O controle normativo exercido torna-se mais rígido, com o que limita de forma mais intensa as possibilidades de escolha dos atores políticos. Conquanto ainda busque se respeitar a liberdade do legislador e dos governantes, o Judiciário passa a colocá-los sob o crivo de suas próprias ponderações a respeito de qual deve ser a leitura mais adequada dos preceitos constitucionais. A jurisdição constitucional, que num momento inicial mostravase mais tímida e lançava mão de sua competência de invalidar escolhas políticas apenas em casos de patente inconstitucionalidade, torna-se mais proativa, com o que não raras vezes busca aperfeiçoar o ordenamento jurídico mediante uma interpretação mais política e mais valorativa acerca dos caminhos a serem trilhados para se garantir e concretizar a Constituição. 
O controle de constitucionalidade, com isso, ganha novos contornos não apenas pelos desenhos institucionais que se firmam, mas particularmente pela forma de seu exercício e pelo escopo que o Judiciário atribui a seu dever de fiscalização normativa.

Os Judiciários nacionais e suas Altas Cortes são vistos, assim, como fóruns em que se permite a rediscussão de praticamente todas as escolhas feitas pelas maiorias governantes. A tomada de decisões políticas fundamentais e a eleição de políticas destas decorrentes ficam constantemente sob o crivo das ponderações dos magistrados, que se tornam partícipes da Política.

O presente trabalho objetiva estudar esse contexto de expansão do Poder Judiciário, principalmente das Cortes Constitucionais, no campo político e no processo de tomada de decisões políticas.

No primeiro capítulo, traça-se o panorama global do fenômeno, apresentando as causas que permitiram a maior ingerência do Judiciário em questões políticas. Nesse sentido, serão apresentadas, inicialmente, suas premissas institucionais, ligadas à construção e à remodelagem dos sistemas de controle de constitucionalidade nos mais diversos Estados. Tal análise envolve, a seu turno, o reforço do constitucionalismo e de seu escopo de garantir a supremacia das Constituições, as importantes mudanças por que passaram os paradigmas da atividade estatal ao longo do século passado, e também a evolução no entendimento a respeito do papel a ser desempenhado pelo Judiciário no intuito de garantir a efetividade constitucional. Em um segundo momento, o enfoque será dado à participação dos atores políticos no reforço dos sistemas de revisão judicial, o que leva à perquirição a respeito dos motivos relevantes que os levaram a estruturar um desenho institucional que, ao fim e ao cabo, coloca o exercício da função normativa sob o crivo do Direito e sob a fiscalização do Judiciário. Por fim, será analisada a importância da política institucional do Poder Judiciário na determinação do grau de sua ingerência política, para então apresentar alguns elementos que permitam compreender o possível embate que pode decorrer entre este e os demais atores políticos no processo de definição de políticas nacionais.

No segundo capítulo, o intuito será o de contextualizar o processo de judicialização da política à realidade brasileira com enfoque voltado à atuação do Supremo Tribunal Federal em nossa realidade política. Conforme se pretende demonstrar, a Constituição de 1988 intensificou as competências de controle do órgão, com o que este assumiu nuances próprias de Cortes Constitucionais. Em vista disso, serão apresentadas 
considerações a respeito dos mecanismos de revisão judicial positivados e das vias de interferência política a que dão acesso. Não obstante, também no caso brasileiro, o exame a respeito da política institucional do Supremo Tribunal Federal mostra-se relevante, na medida em que a forma pela qual a Corte encara seu papel na efetivação dos compromissos constitucionais e democráticos pode intensificar sua ingerência no processo políticodecisório. Com base nesses elementos, analisam-se alguns casos importantes de sua jurisprudência que visam a confirmar tanto as possibilidades que o sistema lhe atribui para efetivamente influir na definição de políticas nacionais quanto a evolução de seu padrão decisório rumo a um viés mais ativista.

O último capítulo examina os efeitos que a participação do Judiciário na Política acarreta ao dimensionamento das funções desempenhadas pelos demais Poderes, especialmente sob o aspecto das premissas do Direito Constitucional pátrio. O embate e o diálogo institucionais tornam-se, aqui, elementos importantes na definição dos rumos da atividade política ligada à tomada de decisões pelas maiorias governantes. Em vista disso, ponderam-se as possibilidades de reação dos demais atores políticos e, com isso, o próprio contexto em que a interferência judicial em questões políticas se desenvolve. Esse contexto, por sua vez, sofre influxos de consequências sistêmicas advindas da própria atividade argumentativa da Corte, que de certo modo restringe a liberdade de escolha dos atores políticos. Ademais, buscar-se-á atentar novamente à política institucional da Corte, mas agora sob um viés mais voltado ao grau de vinculatividade da ratio decidendi que expõe ao exercer o controle de constitucionalidade e às competências que possui para determinar os próprios limites e efeitos relativos aos instrumentos de controle. Por fim, e diante de todos esses elementos, serão apresentadas algumas ponderações a respeito do desafio que o Judiciário se coloca, diante das premissas democráticas, ao assumir a função de controlar o processo de tomada de decisões políticas. 


\section{O JUDICIÁRIO E A DEFINIÇÃO DE DECISÕES POLÍTICAS FUNDAMENTAIS}

A realidade dos mais diversos Estados no tocante à teoria da separação dos Poderes há muito já não reflete sua estruturação clássica, com origens em Montesquieu. ${ }^{1}$ Pode-se dizer que dessa concepção restou apenas a visão geral da divisão tripartite, predominante no Ocidente, i.e., de que a atividade estatal queda divida entre três ordens de macrofunções, cada qual atribuída precipuamente a um dos Poderes, orgânica e estruturalmente distinto dos demais. A forma, em suma, subsiste. Entretanto, seus corolários, bem como o modo de desencadeamento da atribuição de funções e os padrões de interação e interdependência entre os Poderes constituídos vêm sofrendo mudanças significativas.

A distinção estrutural e orgânica não retrata, na essência, as diferenças existentes entre cada um dos Poderes, sendo, antes, seu reflexo. A diferenciação fundamental reside na natureza de cada uma das três funções, bem como na finalidade a que cada qual está eminentemente ligada. Nesse sentido, ao Legislativo foi designada a atribuição de criar preceitos normativos vinculantes a toda a sociedade, no intuito de viabilizar uma ordem de comandos comportamentais pré-ordenada; ao Executivo, a função de governar e de dar efetividade aos regramentos parlamentares no que demandem algum tipo de atuação estatal, de modo a propiciar o desenvolvimento social-político-econômico; ao Judiciário, por sua vez, cabe o papel de instância heterocompositiva de conflitos surgidos quer no âmbito dos demais Poderes, quer no âmbito da vida privada dos indivíduos, tendo ressaltado, portanto, sua função de pacificação de conflitos sociais.

Muito embora a doutrina clássica já antevisse a necessidade de algum grau (mínimo) de compartilhamento entre as atribuições desempenhadas por cada Poder, deve se ter em mente que sua preocupação subjacente voltava-se à organização institucional que permitisse superar o absolutismo ao mesmo tempo em que impedisse abusos de poder, razão pela qual esse compartilhamento de funções era admitido de maneira excepcional, com amplitude bastante restrita e na medida em que estava ligado a um sistema de freios e contrapesos. A preocupação residia menos na reestruturação da sistemática de funcionamento do Estado, e mais na criação de um modelo que obstasse abusos no

\footnotetext{
${ }^{1}$ MONTESQUIEU, Charles Louis de Secondat, baron de la Brède et de. O espírito das leis, tradução de Fernando Henrique Cardoso e Leôncio Martins Rodrigues. Brasília: UnB, 1995, pp. 118-125.
} 
exercício do poder estatal. Conforme aponta José Levi Mello do Amaral Júnior, para Montesquieu, o poder de executar e o de legislar eram neutralizados "pela comunhão de correlatas faculdades de estatuir e impedir." 2 A intenção de conter o poder, instrumentalizada através da racionalização de seu exercício, foi, em suma, a meta inicial. ${ }^{3}$

O desenvolvimento dos Estados, no entanto, mostrou que a contenção do poder como fim em si mesmo resultaria em jogo político de soma zero. Nesse sentido, quanto mais remoto ficava o temor da retomada absolutista, mais se percebia que a preocupação deveria gravitar em torno de se assegurar a harmonia entre os Poderes. Isso é reforçado à medida que o Estado passa tanto a atuar como a ser demandado em novas esferas, o que acaba por impelir o surgimento de novos modelos de interação entre os Poderes. A título exemplificativo tem-se, de um lado, o esgotamento da política econômica de cunho liberal, que passa a exigir maior atuação estatal na esfera econômica; de outro, pode-se mencionar a assunção de novos compromissos pelos Estados no âmbito dos direitos fundamentais, em especial no tocante à garantia de igualdade material entre os indivíduos (fala-se, aqui, dos denominados direitos fundamentais de segunda geração), que por sua vez passou a demandar uma atuação direta do Estado no provimento de condições mínimas a uma vida digna (a exemplo de educação e saúde).

Tais mudanças levaram, v.g., ao surgimento de novos padrões de interação entre Legislativo e Executivo, que passam a ser corresponsáveis (ou, no mínimo, codemandados) pela consecução dos objetivos estatais. Isso porque, em última análise, o desenvolvimento do Estado requer atuação tanto de cunho legislativo quanto de cunho governamental. Dentre as consequências que essa realidade acarreta à sistemática da relação institucional entre os Poderes, destaque-se a que deflagra o processo de compartilhamento da função legiferante. Conquanto a atividade legislativa seja nominal e primordialmente designada ao Legislativo, esta passa a contar, cada vez mais, com a influencia do Executivo, resultando na crescente predominância deste último no processo legislativo - quer na montagem de agendas políticas, quer na formatação e na definição das

\footnotetext{
${ }^{2}$ AMARAL JÚNIOR, José Levi Mello do. "Sobre a organização de poderes em Montesquieu: comentários ao Capítulo VI do Livro XI de O Espírito das Leis”, in: Revista dos Tribunais, v. 868 (fev. 2008), p. 61.

3 "Montesquieu, na verdade, via na divisão dos poderes muito mais um preceito de arte política do que um princípio jurídico. Ou seja, não se tratava de um princípio para a organização do sistema estatal e da distribuição de competências, mas um meio de se evitar o despotismo real. (...) Nesse sentido, o princípio não era de separação de poderes, mas de inibição de um pelo outro de forma recíproca." FERRAZ JÚNIOR, Tércio Sampaio. “O Judiciário frente à divisão de poderes: um princípio em decadência?”, in: Revista USP, n. 21 (mar./mai. 1994), p. 14.
} 
políticas a serem adotadas, processo esse que é ainda mais acentuado em sistemas presidencialistas. ${ }^{4}$

Muito embora essa nova ordem institucional não invalide a ideia de separação de Poderes, permite a reinterpretação de seus corolários. Com base nessa percepção, Karl Loewenstein propõe uma reestruturação da teoria acerca da divisão do poder estatal. Em vez de pautar-se em uma divisão orgânica - i.e., que tome por base os principais órgãos e instituições dentre os quais é disseminado o poder estatal -, seu enfoque possui viés funcional. Nesse sentido, o autor extrai da realidade estatal três ordens de macrofunções, explorando, a partir delas, as mais diversas formas de atuação estatal. Fala-se, assim, em policy determination, policy execution e policy control..$^{5}$ Dentre essas, a que adquire maior relevância para o presente trabalho é a policy determination, ou, em outras palavras, a que diz respeito à escolha das políticas fundamentais do Estado.

A definição do que seja uma política fundamental, ou uma macropolítica ${ }^{6}$, não é tarefa fácil. O termo engloba, sobretudo, questões sensíveis que conformam uma comunidade política e estabelecem as premissas sob as quais esta se desenvolve (inclusive juridicamente). Nas palavras do próprio Loewenstein, podem envolver questões de cunho eminentemente político, econômico-social e até mesmo moral. ${ }^{7}$ Some-se a isso a definição a respeito de direitos fundamentais, que em última análise leva a perquirições a respeito dos limites dos direitos dos indivíduos - e, tão relevante quanto, decisões que envolvem ponderações entre tais direitos. Tratando-se de questões absolutamente basilares de todo e qualquer Estado, razoável afirmar, como o faz Loewenstein, que toda Constituição traz em

\footnotetext{
${ }^{4}$ FERREIRA FILHO, Manoel Gonçalves. Do Processo Legislativo. $5^{\text {a }}$ edição. Saraiva: São Paulo, 2002, pp. 123 e ss.

${ }^{5}$ LOEWENSTEIN, Karl. Teoría de la Constitución. 2a edição. Barcelona: Ediciones Ariel, 1970, pp. 57 e ss.

${ }^{6}$ Faz-se aqui alusão ao que Ran Hirschl denomina "mega-polítics": "matérias de suma e última significância política que frequentemente definem e dividem toda a política. Elas podem abranger resultados eleitorais e corroboração de mudança de regime até questões fundamentais à identidade coletiva, bem como processos de construção nacional ligados à própria natureza e definição do corpo político como um todo." HIRSCHL, Ran. "The judicialization of mega-politics and the rise of political courts", in: Annual Review of Political Science, v. 11 (jun. 2008), p. 93 (tradução própria).

${ }^{7}$ Segundo o autor, a policy determination representa "a escolha de uma, entre várias possibilidades políticas fundamentais frente às quais se encontra a comunidade estatal. Como decisões políticas fundamentais, devese considerar aquelas resoluções da sociedade que são decisivas e determinantes, no presente e frequentemente no futuro, para a conformação de tal comunidade. Concernem tanto a assuntos externos quanto internos, materialmente podem ser de natureza política, socioeconômica e até moral, por exemplo, quando se referem a questões religiosas. (...) Todas as constituições apresentam, portanto, uma decisão política fundamental (...). Não obstante, estas oportunidades para o exercício do poder constituinte costumam ocorrer raramente. Em outros campos, haverá de se tomar decisões políticas fundamentais quando se fizer necessária uma solução ante o enfrentamento de diferentes interesses e ideologias. E a maior parte destas decisões conformadoras das circunstâncias obrigam a um compromisso.” LOEWENSTEIN, Karl, op. cit., p. 63 (tradução própria).
} 
si uma série de decisões políticas fundamentais, a partir das quais se desenvolvem a legislação infraconstitucional e a atuação estatal.

Tem-se por consequência natural que cabe precipuamente ao Legislativo a definição de decisões políticas fundamentais e das políticas delas decorrentes. Afinal, os regimes democráticos possuem por nota distintiva a atuação estatal e a conformação dos comportamentos sociais com base na lei. A fortiori, essa máxima deve se refletir no que diz respeito à definição dos pré-compromissos de maior magnitude que, em última análise, traduzem os anseios e aspirações da sociedade. O Poder incumbido da função legiferante ocupa, portanto, papel central nessa questão. Ao menos em tese.

A visão funcional de Loewenstein permite, de todo modo, reconhecer na crescente alteração nos padrões de interação institucional entre os órgãos estatais a natural influência do Governo - ou do Executivo, quando este cumule funções de Estado e de Governo - na definição de políticas fundamentais, dado que esse órgão paulatinamente passa a assumir papel de destaque na consecução dos objetivos estatais. ${ }^{8}$ Ainda que essa realidade possa trazer perquirições a respeito dos limites da teoria da separação dos Poderes, fato é que tanto Governo quanto Parlamento exercem funções de cunho eminentemente político e possuem legitimidade democrática. Em vista disso, conquanto possa haver críticas à participação governamental na atividade legiferante, ela ocorre numa seara tipicamente política - e, nesse sentido, o Executivo, de natureza também política, lança mão de instrumentos que, para bem ou para mal, são-lhe disponibilizados pelas próprias regras do jogo, positivadas e institucionalizadas.

Não obstante, o século XX e a primeira década do século XXI permitiram vislumbrar o surgimento e o desenvolvimento de um novo partícipe na eleição das macropolíticas estatais e na definição do conjunto normativo delas decorrente, qual seja, o Poder Judiciário. ${ }^{9}$ Parece instintivo conceber que este, enquanto instituição voltada à

\footnotetext{
8 “[A]inda que as decisões políticas sejam frequentemente inspiradas e influídas por detentores do poder invisíveis, sua formulação e realização estão nas mãos dos detentores do poder legítimos, quais sejam, do governo e (...) do parlamento. (...) Pertence, não obstante, à essência do constitucionalismo que em um determinado momento do processo do poder tenha de ter espaço ao menos uma colaboração entre governo e parlamento." LOEWENSTEIN, Karl, op. cit., pp. 64-65 (tradução própria).

${ }^{9}$ Cf. TATE, C. Nael; VALLINDER, Torbjörn (eds.). The Global Expansion of Judicial Power. Nova York: New York University Press, 1995, pp. 1-10; Tom Ginsburg, a seu turno, aponta três ondas de expansão de sistemas de controle de constitucionalidade e da influência política do Judiciário, duas das quais se inserem no contexto do século XX. GINSBURG, Tom. "The Global Spread of Constitutional Review", in: WHITTINGTON, Keith E.; KELEMEN, R. Daniel; CALDEIRA, Gregory A. (eds.). The Oxford Handbook of Law and Politics. Nova York: Oxford University Press, 2008, pp. 81 e ss. A exceção reside em Estados que, apesar de instituir alguma forma de controle de constitucionalidade, passavam ou passaram por regimes autoritários. Nesse sentido, v.g., os exemplos da Checoslováquia e da Polônia, cujas constituições,
} 
heterocomposição de conflitos com base nas normas adotadas pelos entes naturalmente políticos, não deveria tomar parte na escolha dessas mesmas normas (quer sejam decisões políticas fundamentais nos termos prelecionados por Loewenstein, quer sejam regras que simplesmente desdobram tais decisões no âmbito da normativização das relações sociais a exemplo do que seria a policy execution ${ }^{10}$ ). Em primeiro lugar, e agora caminhando novamente com a teoria clássica, por representar uma concentração substancial de competências que dá azo a eventual abuso de poder (em última análise, e como regra, àquele que institui as regras não se deve atribuir competência decisória de conflitos que as tomem por base). Ademais, por não ser um órgão tradicionalmente político e com legitimidade pautada na representação democrática, o Judiciário não seria instância adequada a fazer escolhas que devessem representar, globalmente, na forma de políticas legislativas, os anseios políticos e sociais. ${ }^{11}$ Pode-se pensar que sua eventual atuação nessa seara acarretaria algum grau de politização, o que não parece ocorrer sem prejuízo à neutralidade, à imparcialidade e à independência que se espera daquele a quem se atribuir a competência, o poder e o dever de resolver conflitos, fáticos e jurídicos, em caráter definitivo. ${ }^{12}$ Em suma, o raciocínio os levaria à ilação de que a atuação política do Judiciário poria em jogo sua legitimidade perante a sociedade e os demais órgãos estatais.

Ainda assim, sedimentação de sistemas de controle de constitucionalidade permite o desenvolvimento de novos padrões de interação entre os Poderes. Percebe-se, como fenômeno global, que muito mais que invalidar uma política e, portanto, para além de impor uma não-política, o Judiciário, ao realizar o controle de constitucionalidade, passa a atuar estabelecendo verdadeiras premissas a partir das quais o Estado e os particulares podem e/ou devem atuar. Em uma primeira análise, poder-se-ia compreender isso como uma consequência natural do exercício da revisão constitucional - no sentido indicado por

respectivamente em 1968 e 1982, instituíram sistemas de controle de constitucionalidade que permaneceram absolutamente ineficazes ante o domínio pela União Soviética. Nesse sentido, ver: CAPPELLETTI, Mauro. The judicial process in comparative perspective. Oxford: Calendon Press, 1989, p. 188.

${ }^{10}$ Há que se destacar ainda que para Loewenstein esta seria apenas um dos vieses do policy execution. Outra manifestação dessa função seria vislumbrada na atividade judicial voltada à pacificação de conflitos por meio da aplicação das normas jurídicas criadas por outros entes estatais. LOEWENSTEIN, Karl, op. cit., p. 67.

${ }^{11}$ Em defesa da falta de legitimidade do Judiciário, em especial das Cortes Constitucionais, em participar na definição de políticas nacionais, ver: WALDRON, Jeremy. "The Core of the Case Against Judicial Review", in: The Yale Law Journal, v. 115, n. 6 (2006), pp. 1359 e ss.; sobre o debate que envolve a questão, ver: TAVARES, André Ramos. Tribunal e jurisdição constitucional. São Paulo: Celso Bastos Editor, 1988, pp. 71 e ss.

${ }^{12}$ Sobre a judicialização da política e a politização do Judiciário, ver: FERREIRA FILHO, Manoel Gonçalves. "O Papel Político do Judiciário e suas Implicações", in: FRANCISCO, José Carlos (coord. e coautor). Neoconstitucionalismo e atividade jurisdicional: do passivismo ao ativismo judicial. Belo Horizonte: Del Rey, 2012, pp. 231-240. 
Kelsen, de se estar diante de uma atividade que, mutatis mutandis, possui notas de uma legiferação com sinal negativo. ${ }^{13}$ A realidade dos mais diversos Estados, entretanto, mostra não ser esse o caso. Tem-se, em verdade, que o Judiciário passa a desenvolver papel ativo e decisivo na definição de decisões políticas fundamentais ou de normas que delas decorrem, participando efetivamente do jogo institucional pelo qual se faz as escolhas das políticas legislativas nacionais. ${ }^{14}$

O maior grau de participação das Cortes Constitucionais nessa função estatal é decorrência de uma série de fatores, que, para além de explicarem suas premissas estruturais, indicam igualmente as situações mais favoráveis para seu desenvolvimento e sedimentação nas mais variadas realidades político-institucionais.

Nesse sentido, o propósito deste capítulo é o de apontar as razões que levam à maior (e efetiva) participação do Judiciário na definição de políticas nacionais, sejam decisões políticas fundamentais ou normas delas decorrentes, explorando as razões político-institucionais que dão causa e que favorecem a expansão do Judiciário, para então buscar compreender as consequências desse fenômeno.

\subsection{O surgimento e o desenvolvimento do controle de constitucionalidade: causas institucionais}

Uma primeira série de fatores que levam ao surgimento e expansão da atuação judicial na seara das decisões políticas fundamentais possui ligação com o arranjo institucional em torno da própria função de controle de constitucionalidade. Com isso, quer-se referir não apenas à sua estruturação normativo-formal, com base na própria Constituição, mas igualmente às premissas que pautam seu exercício, o que leva em conta especialmente o surgimento de um novo modelo de atuação estatal ao longo do século XX, que por sua vez acarreta uma reestruturação do próprio papel a ser desempenhado pelo Judiciário.

\footnotetext{
13 “[A]nular uma lei é estabelecer uma norma geral, porque a anulação de uma lei tem o mesmo caráter de generalidade que sua elaboração, nada mais sendo, por assim dizer, que a elaboração com sinal negativo e portanto ela própria uma função legislativa.” KELSEN, Hans. Jurisdição constitucional. São Paulo: Martins Fontes, 2003, pp. 151-152.

${ }^{14}$ Sobre o assunto, ver: HIRSCHL, Ran. "The judicialization of mega-politics and the rise of political courts", op. cit., pp. 93 e ss.
} 
Nesse sentido, no presente capítulo três desses fatores serão objeto de estudo. O primeiro deles volta-se ao pressuposto teórico no qual se funda a ideia do controle de constitucionalidade, qual seja, o reconhecimento da supremacia das normas constitucionais. O segundo elemento relevante para a compreensão da expansão da atuação judicial funda-se nas alterações dos paradigmas estatais e do modelo-padrão de sua atuação ao longo do século $\mathrm{XX}$, que propiciou o agigantamento do Poder Executivo especificamente em seu aspecto governamental. Por fim, buscar-se-á apontar o processo de mudanças relativas ao exercício da atividade jurisdicional, que igualmente desempenha papel fundamental na compreensão do fenômeno da expansão do Poder Judiciário.

\subsubsection{Premissa teórica: a supremacia da Constituição}

A ideia de que algumas normas possuem preponderância sobre outras há muito informa o pensamento político e filosófico. ${ }^{15}$ Foi o processo político que culminou no constitucionalismo moderno, entretanto, que dotou esse pensamento de sistematicidade teórica. Ao se buscar estruturar e racionalizar o exercício do poder estatal com base em constituições escritas, nas quais se positivam não apenas regras relativas à separação e distribuição de atribuições e funções do Estado, mas igualmente uma série de limites e, num momento posterior, verdadeiras metas à sua atuação ${ }^{16}$, esse processo acabou por atribuir um elemento de unicidade normativa ao ordenamento jurídico.

Ensina Nicola Matteucci que o constitucionalismo se desenvolve em um contexto de democratização da política estatal e, nesse sentido, as diversas Constituições passam a envolver também a questão de sua legitimidade e de sua função na sociedade. ${ }^{17}$ No que tange à legitimidade, refere-se ao processo pelo qual ela se firma e se torna aceita perante a comunidade à qual se dirige, que a seu turno é resultado tanto do conteúdo das normas constitucionais quanto do processo de sua elaboração - que, por pressuposto nos regimes democráticos, deve contar com a participação popular, direta ou indireta. No tocante à sua função, volta-se a atenção à necessidade de se garantir a efetividade de suas previsões e,

\footnotetext{
${ }^{15}$ FERREIRA FILHO, Manoel Gonçalves. O Poder Constituinte. $4^{\text {a }}$ edição. São Paulo: Saraiva, 2005, pp. 3 e ss.

${ }^{16}$ Sobre o constitucionalismo e seus ciclos, ver: AMARAL JÚNIOR, José Levi Mello do. "O constitucionalismo", in: FRANCISCO, José Carlos, op. cit., pp. 3-12.

${ }^{17}$ MATTEUCCI, Nicola. Organización del poder y libertad: historia del constitucionalismo moderno. Madri: Trotta, 1998, p. 25.
} 
com isso, tem-se que as limitações estabelecidas ao poder estatal e os direitos instituídos em favor dos indivíduos devem ser observados e respeitados, sem o que ter-se-ia a inocuidade da própria ideia de limitação do poder estatal.

Para garantir esse modelo, indispensável que se reconheça que tais normas não possam ser alteradas por processos ordinários de legiferação, bem como que haja uma instância competente para analisar eventuais transbordamentos dos parâmetros e dos limites constitucionais. ${ }^{18}$

Quanto ao primeiro, fala-se em limites à própria possibilidade de reforma dos enunciados constitucionais, no sentido de serem estipulados processos específicos e mais dificultosos para sua reforma e emenda - em suma, rigidez constitucional. ${ }^{19}$ Para além de estabelecer a supremacia formal às normas previstas nas Constituições, que por conseguinte não podem ser alteradas nem derrogadas por meio do processo legislativo ordinário ou por simples atos normativos governamentais, busca-se protegê-las contra maiorias contingenciais que possam objetivar romper ou arrefecer os pré-compromissos estabelecidos pelo Constituinte, em especial contra grupos minoritários. No tocante ao segundo ponto, chega-se à ideia do controle de constitucionalidade, no sentido de criar um sistema que permita extirpar do ordenamento atos normativos que desrespeitem os limites e os parâmetros constitucionais. ${ }^{20}$ Para essa incumbência, a teoria da separação de Poderes parece apontar naturalmente ao Judiciário, tendo em vista que, do ponto de vista institucional, este não participa do processo político relativo à produção normativa: afinal, o Judiciário é estruturado como um terceiro neutralizado ${ }^{21}$, seja do ponto de vista dos conflitos interindividuais, seja do ponto de vista do jogo político estatal - e portanto, da perspectiva da produção normativa que regula a vida social.

O controle de constitucionalidade pode ser visto, portanto, como um reforço ao sistema de controles mútuos representada pela ideia de "freios e contrapesos". Cumpre o

\footnotetext{
${ }^{18}$ RAMOS, Elival da Silva. Controle de constitucionalidade no Brasil: perspectivas e evolução. São Paulo: Saraiva, 2010, pp. 41 e ss.

${ }^{19}$ SILVA, José Afonso da. O constitucionalismo brasileiro (evolução institucional). São Paulo: Malheiros, 2011, pp. 100 e ss.

${ }^{20}$ RAMOS, Elival da Silva, Controle de constitucionalidade no Brasil: perspectivas e evolução, op. cit., pp. 46-47.

${ }^{21}$ Não se faz alusão, aqui, à neutralidade do julgador relativa à atividade hermenêutica, mas sim em relação aos interesses envolvidos na lide cuja resolução lhe foi atribuída (e, aqui, admite-se o termo lide em concepção absolutamente ampla, incluindo mesmo questões de controle abstrato de normas, no qual há interesse daquele que impugna determinado ato normativo contraposto ao da autoridade estatal que busca sua manutenção).
} 
essencial papel de garantia da supremacia do texto constitucional ${ }^{22}$, impondo a observância de suas disposições, ainda que por via reversa e reativa - i.e., por meio da repressão dos atos dos demais Poderes (ainda que isso possa, em alguma medida e em certos casos, transbordar o plano meramente normativo e acarretar a imposição de obrigação de atuação governamental junto à sociedade ou a determinados indivíduos) e mediante provocação dos interessados. N'Os Artigos Federalistas, Hamilton já ponderava a imprescindibilidade do controle de constitucionalidade no contexto em que se busque garantir a supremacia constitucional e o controle do poder, sem o qual todas as limitações ali previstas equivaleriam a nada. ${ }^{23}$

A concretização e o desenvolvimento de mecanismos para a garantia da supremacia da Constituição por meio da atuação judicial, cujas origens modernas são atribuídas à Suprema Corte dos Estados Unidos no célebre caso Marbury v. Madison ${ }^{24}$, representam, portanto, o primeiro passo para o desenvolvimento da atuação judicial na definição de macropolíticas estatais. Conforme indica Loewenstein, esse instrumento de atuação do Judiciário não possui respaldo na teoria clássica da separação de Poderes ${ }^{25}$, e em verdade transmuta esse órgão em um novo e autêntico "detentor do poder" ${ }^{26}$, equiparável ao Congresso e ao Governo. Afinal, a competência de invalidar (lato sensu) uma decisão política fundamental assemelha-se, em alguma medida, à competência de determinar uma decisão política fundamental - ainda que seja uma "não-política", i.e., uma decisão que simplesmente impeça a positivação e realização de uma política desejada pela articulação governamental majoritária -, o que igualmente se aplica a políticas dela decorrentes.

\footnotetext{
${ }^{22}$ SILVA, José Afonso da., op. cit., pp. 99-100.

${ }^{23}$ MADISON, James; HAMILTON, Alexander; JAY, John. Os Artigos Federalistas 1787-1788: edição integral. Rio de Janeiro: Nova Fronteira, 1993, p. 480.

${ }^{24}$ Caso 5 U.S. 137 (1803). Muito embora esse caso seja citado como o precursor do controle de constitucionalidade, há decisões anteriores, na própria jurisprudência estadunidense, em que cortes estaduais afirmavam-se competentes para anular legislação inconstitucional com base em preceitos da common law. A importância de Marbury v. Madison está em se tratar do primeiro caso em que a Suprema Corte explicitamente reconheceu sua competência para invalidar leis inconstitucionais do Congresso e por tomar por base o próprio texto constitucional (e não princípios da common law). Nesse sentido, ver: EDLIN, Douglas E. "Judicial Review without a Constitution", in: Polity, v. 38, n. 3 (jul. 2006), pp. 345 e ss.

${ }^{25}$ LOEWENSTEIN, Karl, op. cit., p. 67.

26 "Os detentores de poder oficiais e visíveis são aqueles órgãos e autoridades e correspondentes funcionários que estão encarregados pela constituição do Estado - normalmente, ainda que nem sempre, contida em um documento formal - de desempenhar determinadas funções no interesse da sociedade estatal." LOEWENSTEIN, Karl, op. cit., p. 36. Para o autor, os detentores do poder representam órgãos de natureza política que, em última análise, podem fazer as escolhas das decisões políticas fundamentais. Tradicionalmente, pois, elenca como detentores do poder o governo, o parlamento e os próprios destinatários do poder (i.e., o povo) quando organizados através de partidos políticos, pelo que passam a participar do processo político.
} 
Pode-se argumentar que a participação do Judiciário na definição de enunciados normativos seja algo idiossincrático à sua função de resolução de conflitos. Afinal, ao definir a interpretação das normas, os órgãos jurisdicionais acabariam por participar da construção da ordem jurídica vigente, seja em sistemas de common law, em que isso assume notas mais visíveis em razão dos precedentes vinculantes, seja em sistemas de civil law, em que, embora a força da jurisprudência seja mais tênue - por não ser, como regra, vinculante -, acaba por representar importante fator argumentativo na propositura e na resolução de conflitos. ${ }^{27}$ Em vista disso, ao realizar o controle de constitucionalidade, o Judiciário apenas estaria exercendo sua natural função hermenêutica, muito embora, aqui, em relação a determinado enunciado normativo. Não haveria, portanto, nada de inovador no controle das normas no tocante à participação judicial na criação do Direito.

Conquanto a premissa desse argumento seja adequada - i.e., a função hermenêutica sempre traz em si um elemento criativo ao Direito -, fato é que ao tutelar a supremacia da Constituição, reconhecendo-a como um centro de normas basilares que apenas podem ser alteradas por meio de processos específicos e mais dificultosos de emendas, tem-se uma nova dimensão. Quando se está diante de conflitos que discutam a própria higidez de uma norma, no sentido de expurgá-la do ordenamento, o julgador é chamado a exercer função que vai além de fixar a correta aplicação da lei (se não do ponto de vista funcional, ao menos do ponto de vista pragmático). Não se está a definir, apenas, como determinada regra deve ser aplicada, mas, sim, se a própria regra pode ser mantida no ordenamento. No exercício da atividade exegética trivial, o juiz define a interpretação que lhe parece mais adequada; no controle de constitucionalidade, ainda que também proceda à mesma definição, toma-se um posicionamento relativo à própria escolha legislativa que informou a criação da norma. Quando, por sua vez, se alça a discussão do controle de constitucionalidade para questões que assumem relevância de macropolíticas, tem-se que o julgador passa a ser partícipe da definição das políticas estatais fundamentais. $^{28}$

Ainda assim, se essa participação se mostra como algo natural ao próprio processo de controle da Constituição, este último representa um ponto de partida ao desenvolvimento da atuação judiciária na seara de escolhas legislativas. As notas que

\footnotetext{
${ }^{27}$ A respeito das diferenças entre a vinculatividade da jurisprudência entre sistemas de common law e civil law, ver: DAVID, René. Os grandes sistemas do direito contemporâneo. $3^{\text {a }}$ edição. São Paulo: Martins Fontes, 1996, pp. 340 e ss.

${ }^{28}$ FERREIRA FILHO, Manoel Gonçalves. "O papel político do Judiciário e suas implicações", in: FRANCISCO, José Carlos, op. cit., pp. 229-231.
} 
informarão uma maior ou menor ingerência nesse processo resultam, portanto, de outros fatores, que serão analisados ao longo deste capítulo, e que condicionam e influenciam a maneira pela qual o Judiciário lança mão da competência de controlar a constitucionalidade das normas.

1.1.2 O século XX e a transformação nos paradigmas constitucionais e estatais.

Fatores importantes para o fenômeno objeto de estudo residem nas mudanças por que passou o modelo estatal ocidental ao longo do século XX. Pode-se mencionar, a esse respeito, $(i)$ a expansão do rol de direitos constitucionalizados, (ii) o surgimento de um novo programa de intervenção estatal e (iii) a propagação principiológica no âmbito das Constituições. Em razão da inter-relação existente entre esses três principais elementos, serão eles inicialmente expostos para, então, se apresentarem as consequências daí decorrentes para a expansão da atuação judicial na seara política.

De início, tem-se o esgotamento do modelo constitucional liberal que, para além da estruturação organizacional do Estado, preocupava-se em tutelar, como regra, as denominadas liberdades públicas. Estas voltavam-se, sobretudo, a garantir uma série de direitos e prerrogativas que, ligadas à lógica liberal de valorização do indivíduo, buscavam criar um núcleo mínimo de autonomia e autodeterminação ao indivíduo que ficasse normativamente imunizado e protegido contra possíveis arbitrariedades do poder estatal. Fala-se, assim, em liberdade de expressão, de crença, de associação, que, muito embora sejam passíveis de regulamentação estatal - dado que nenhum direito é absoluto -, impõem sobretudo uma abstenção do Estado, no sentido de não impedir seu exercício pelos cidadãos. Sua proteção, por sua vez, impunha a determinação de um não-fazer ao Estado. $^{29}$

O modelo liberal, entretanto, pautava-se na premissa da garantia de uma igualdade formal, que por sua vez não resolvia o problema das disparidades sociais - em outras palavras, da inexistência (e do aprofundamento) da desigualdade de condições entre os destinatários das normas - sem o que não se cumpria o papel de permitir o exercício

${ }^{29}$ SILVA, Luís Virgílio Afonso da. "O Judiciário e as políticas públicas: entre transformação social e obstáculo à realização dos direitos sociais", in: SOUZA NETO, Cláudio Pereira; SARMENTO, Daniel (coords.). Direitos Sociais: fundamentos, judicialização e direitos sociais em espécie. Rio de Janeiro: Lumen Juris, 2008, pp. 587-599 (em especial, pp. 589-590). 
daquelas liberdades e de propiciar o desenvolvimento de uma sociedade mais justa e democrática. Em suma, a igualdade formal protegida constitucionalmente e tutelada mediante a generalidade e abstração normativa pouco a pouco mostrou-se insuficiente, dado que não permitia o pleno gozo daqueles direitos. $\mathrm{O}$ anseio democrático fez propagar, assim, movimentos sociais demandando maior paridade de condições e oportunidades, que resultaram, ao fim e ao cabo, no reconhecimento de uma nova era de direitos que, para além de possuírem finalidades próprias, mostravam-se instrumentais à realização das liberdades públicas. ${ }^{30}$

Nesse sentido, a Europa Ocidental e América Latina vivenciaram uma tendência da positivação constitucional de direitos de cunho social e econômico, que se somavam aos direitos individuais de cunho liberal. ${ }^{31}$ Fala-se, assim, em direitos relativos à saúde, à educação e à moradia, em suma, a uma vida digna. Teve-se, com isso, o aumento do campo de incidência das Constituições, que passam a tutelar também direitos que assumem novas dimensões, especialmente por se revestirem de um viés econômico, por demandarem um fazer do Estado - envolvendo em maior intensidade questões de orçamento público - e por terem como destinatário toda a coletividade. ${ }^{32} \mathrm{O}$ que importa destacar, para os fins da presente pesquisa, é que nos Estados que seguiram esse processo, reconheceu-se que a previsão de tais direitos impunha - independentemente da discussão a respeito de se seriam individual e imediatamente exigíveis pelos indivíduos - ao menos um compromisso e uma vinculação ao Estado em buscar garantir sua efetividade, o que por sua vez acaba por alargar a influência do Judiciário (em especial das Cortes Constitucionais) na medida em que se procura dotar tais direitos de justiciabilidade num crescente processo de judicialização da Política. ${ }^{33}$ Isso acarreta uma mudança na concepção da própria dimensão

\footnotetext{
${ }^{30}$ FERRAJOLI, Luigi. "Estado Social y Estado de Derecho", in: ABRAMOVICH, Víctor; AÑON, María José; COURTIS, Christian. Derechos sociales: instrucciones de uso. México: Fontamara, 2006, pp. 11-13. O autor menciona, ainda, como princípios do modelo estatal liberal a publicidade dos atos legislativos, administrativos e judiciais, bem como a sujeição de todos os atos estatais ao controle jurisdicional.

${ }^{31}$ Idem, ibidem, loc. cit.

${ }^{32}$ Sobre a questão dos custos dos direitos sociais, ver: SILVA, Luís Virgílio Afonso da. "O Judiciário e as políticas públicas: entre transformação social e obstáculo à realização dos direitos sociais", in: SOUZA NETO, Cláudio Pereira; SARMENTO, Daniel, op. cit., pp. 590 e ss.

${ }^{33}$ QUEIROZ, Cristina. Interpretação constitucional e poder judicial: sobre a epistemologia da construção constitucional. Coimbra: Coimbra Editora, 2000, pp. 57 e ss. Destaca-se a seguinte ponderação da autora: “Esta 'transformação' na concepção dos direitos (...) é estranha a esta dialéctica subjectividade-objectividade. A 'vontade da constituição' (...) não é a vontade do momento (incluindo a vontade dos seus intérpretesaplicadores), mas uma vontade que tende para um fim. A jurisdição constitucional confere carácter objectivo aos direitos fundamentais, transformando-os em 'bens jurídicos protegidos', sem perda da sua individualidade, fixando ao mesmo tempo os 'deveres de acção' do Estado. Esta 'revolução' ou 'transformação' nos direitos fundamentais impõe uma combinação jurídico-processual dos seus aspectos subjectivos e objetivos nas condições actuais, socio-estatais, de um Estado regulador, que se pretende ainda
} 
dos direitos fundamentais e dos valores positivados na Constituição, gerando o que Cristina Queiroz descreve como a ampliação do significado do princípio da igualdade, por meio do reconhecimento de uma obrigação geral de objetividade, que demanda por sua vez a cooperação dos três Poderes - e, portanto, com participação do próprio Judiciário - na definição do significado do texto constitucional. ${ }^{34}$

Nem todos os Estados com aspirações democráticas, entretanto, encamparam os direitos econômico-sociais em suas Constituições. Os Estados Unidos são exemplo clássico daqueles que passaram ao largo do reconhecimento normativo desses direitos chamados de segunda geração. Ainda assim, viram-se diante do mesmo contexto social em que a maior intervenção governamental na economia e na sociedade mostrava-se indispensável ao desenvolvimento do próprio Estado e à efetivação dos direitos efetivamente garantidos constitucionalmente.

Seja como for, fato é que, diante desse contexto, surge o modelo que se convencionou chamar de Welfare State e que, no anseio de executar as políticas econômico-sociais, e somado ao processo de decadência do Parlamento, resultou em verdadeira primazia do Executivo. Este, objetivando levar a cabo as novas metas e ideais, e encampando novas atribuições centralizadoras de competências, passa à posição de domínio na regulamentação (lato sensu) das mais diversas searas estatais. ${ }^{35}$ Tornou-se, não raras vezes, verdadeiro protagonista na produção normativa: de um lado, pela expansão da regulamentação (stricto sensu) no âmbito da própria Administração, como corolário do aumento de competências governamentais (i.e., aumento de seu poder de intervenção) e da expansão desenfreada de órgãos estatais reguladores; por outro, pela influencia que passou a exercer sobre a agenda de trabalhos do Legislativo e pelas competências normativas extraordinárias que se lhe atribuiu - ainda que sob o pretexto de somente poder utilizá-las em situações emergenciais ${ }^{36}$, com todas as consequências advindas da vagueza da expressão e da ausência de parâmetros legais que a delimite.

A atividade governamental expande-se, assim, tanto organicamente, quanto no tocante ao âmbito de suas competências. A regulamentação e a intervenção na economia e

como um Estado democrático e constitucional. Dentro do sistema jurídico isso significa o crescimento do poder da justiça e um alargamento do espaço de intervenção dos tribunais. (...) Aqui basta mencionar a 'ponderação de bens', a utilização acrescida das 'cláusulas gerais', a invasão da jurisprudência de orientação sociológica, a análise económica do direito e outras tantas formas de 'cientificação' da justiça.” Idem, ibidem, pp. 63-64 (realces originais).

${ }^{34}$ Idem, ibidem, pp. 247 e ss.

${ }^{35}$ FERREIRA FILHO, Manoel Gonçalves. Do Processo Legislativo, op. cit., pp. 123-127.

${ }^{36}$ V.g., a medida provisória brasileira e o decreto-legge italiano. 
o desenvolvimento de políticas assistencialistas demandam, em maior ou menor grau, a criação de órgãos administrativos, que atuam com base em parâmetros normativos préestabelecidos (afinal, tem-se por premissa que a Administração Pública apenas pode agir mediante prévia autorização normativa).

Paralelamente, os traumas da Segunda Grande Guerra acarretam também o desgaste dos paradigmas liberais-positivistas relativos à organização e à aplicação do ordenamento jurídico. ${ }^{37}$ As experiências do legalismo estrito acabaram por expor uma potencialidade nociva e antidemocrática quando não haja no sistema jurídico a prescrição de limites intransponíveis quanto àquilo que pode ser objeto de normatização. Passa-se a exigir, com maior intensidade, uma legitimação normativa que não mais se esgote no simples formalismo referente ao modo de produção das leis. Em vista disso, e considerando ser a Constituição o referencial último da validade das normas estruturadas sob sua égide, entendeu-se pela positivação, naquele âmbito, de uma série de preceitos que servissem de guia ao próprio conteúdo da legiferação infraconstitucional - e, em alguns casos, até mesmo ao conteúdo das reformas constitucionais. Entretanto, e dado que cumpre às Constituições estabelecer apenas diretrizes básicas no tocante ao processo legislativo e à atuação estatal, parece razoável que as limitações de cunho material sejam também marcadas por algum nível de abstração que permita razoável grau de liberdade de escolhas pelas maiorias que se sucedem nos órgãos voltados à produção normativa. Entra em voga, assim, a era dos princípios, que, no intuito de exigir que, para além da fundamentação de forma, a produção normativa possua também limites materiais, promove verdadeira disseminação principiológica - i.e., enunciados com alta carga semântica e baixa densidade normativa $^{38}$ - no âmbito das Constituições escritas - reiterando-se que, muito embora descreva-se aqui o fenômeno de uma forma global, ele diz respeito sobretudo aos países da Europa Ocidental continental e àqueles cujas constituições se inspiram nesse modelo.

Todos esses fatores, conforme já mencionado, contribuem fortemente à expansão da intervenção judicial na seara política.

\footnotetext{
${ }^{37}$ CAPPELLETTI, Mauro. The judicial process in comparative perspective, op. cit., pp. 9 e ss.; LAFER, Celso. A reconstrução dos direitos humanos: um diálogo com o pensamento de Hannah Arendt. São Paulo: Companhia das Letras, 1988, pp. 77 e ss.

${ }^{38}$ A respeito da densidade normativa das normas e seus efeitos sistêmicos, ver: DIMOULIS, Dimitri. Positivismo Jurídico: introdução a uma teoria do direito e defesa do pragmatismo jurídico-político. São Paulo: Método, 2006, pp. 245 e ss.
} 
De um lado, porque a maior atuação estatal nos campos social e econômico amplia a rede de atos passíveis de serem controlados pelo Judiciário, dado que, no âmbito da Administração Pública, a intervenção do Estado deve vir pautada e autorizada por normatização previamente estabelecida, que, por sua vez, deve possuir baliza constitucional. Essa sistemática abre espaço para que se questione, junto ao Poder Judiciário, a legitimidade dos programas governamentais, a competência das agências reguladoras, a retidão das práticas voltadas ao desenvolvimento econômico e às políticas públicas, com o que o Judiciário passa, potencialmente, a ser parte integrante do processo de definição das políticas estatais.

Para tanto, mostra-se, a priori, indiferente o fato de ter havido expansão do rol de direitos constitucionalizados. Nesse viés específico, o foco reside menos no quantum de paradigmas constitucionais a servirem de baliza para controle das normas e mais na ampliação e disseminação de atos passíveis de serem controlados e na relevância socialeconômica de seu objeto - i.e., da matéria sobre que versam. E os Estados Unidos, conforme já mencionado, são exemplo claro disso. O Governo e o Congresso Nacional estadunidenses viram-se, a partir do segundo quartel do século $\mathrm{XX}$, impelidos a intervirem fortemente na economia de modo a arrefecer os efeitos deletérios da crise de 1929. A expansão dos gastos públicos como forma de fomentar o mercado de trabalho, a criação de agências governamentais e implementação de políticas de controle de preços estão dentre as medidas utilizadas como forma de se buscar reverter a recessão. Não tendo havido mudança constitucional substancial nesse sentido que balizasse expressamente o novo modelo de atuação, o Governo e o Congresso o fizeram com base em novas interpretações dadas aos critérios de competência estabelecidos na Constituição do país. A reação da Suprema Corte dos Estados Unidos, como é cediço, foi inicialmente arrebatadora para os planos do governo de Theodore Roosevelt, declarando inconstitucionais uma série de programas de incentivos adotados pelo governo federal. ${ }^{39}$ Ainda que posteriormente o Governo e o Congresso Nacional tenham contado com a aprovação da Suprema Corte quanto aos programas do New Deal, fato é que tem-se aí exemplo clássico do poder e da

\footnotetext{
${ }^{39}$ VIEIRA, Oscar Vilhena. A Constituição e sua reserva de Justiça (um ensaio sobre os limites materiais do poder de reforma). São Paulo: Malheiros, 1999, pp. 76 e ss.
} 
influência de que é dotado o Poder Judiciário na definição e na implementação de políticas fundamentais estatais. ${ }^{40}$

O mesmo ocorre no âmbito das agências reguladoras, como demonstra o caso estudunidense $^{41}$. Muito mais que fiscalizar a competência regulatória desses órgãos, estabeleceu-se nesses países uma jurisprudência pródiga em criar balizas à sua própria produção normativo-reguladora, havendo, assim, verdadeiro escrutínio do modus operandi dessas agências.

Por outro lado, mais direitos e princípios constitucionalizados acarretam o alargamento dos paradigmas que podem ser empregados como meio de controle dos atos estatais. O Judiciário vê-se, assim, cada vez mais provocado a exercer sua função de controle em novas searas, (i) quer no que diga respeito à efetivação dos direitos de cunho social e econômico - nos Estados que os positivaram em suas Constituições -, o que por sua vez envolve tanto discussões sobre sua justiciabilidade direta - no sentido de serem exigíveis individual ou coletivamente -, quanto a novos critérios de competência de atuação estatal que são estruturados para permitir sua implementação pelo Estado, (ii) quer no que se refira ao controle do conteúdo normativo de decisões políticas independentemente, nesse último caso, de se voltarem especificamente à implementação de políticas públicas e a permitir maior atuação estatal na economia.

No primeiro caso, o Judiciário é instado a estabelecer parâmetros relativamente à própria vinculação do Estado àqueles direitos, aos critérios para definir se - e em que medida - consubstanciam direitos subjetivos passíveis de serem imediatamente exigíveis individual ou coletivamente e ao próprio conteúdo desses direitos. ${ }^{42}$ Nesse aspecto, a participação judicial pode ser tanto num aspecto global, fixando obrigações ao Estado e definindo status a esses direitos, quanto num aspecto mais pragmático e imediato - como ocorre no Brasil atualmente -, no sentido de garantir efetividade a esses direitos em prol de indivíduos (ou de grupos) que os reivindicam ante a ineficiência - e mesmo impossibilidade - governamental em prover a todos tudo aquilo que, em tese, se pode fazer inserir no âmbito da essencialidade de direitos como saúde e educação. Nesta última hipótese, muito mais que propiciar a intervenção judicial na fixação das balizas de

\footnotetext{
${ }^{40} \mathrm{~A}$ esse respeito, em especial quanto às mudanças na jurisprudência da Suprema Corte estadunidense antes e depois do New Deal, ver: TUSHNET, Mark. The new constitutional order. Princeton: Princeton University Press, 2003, pp. 33 e ss.

${ }^{41}$ SHAPIRO, Martin. "Judicialization of politics in the United States", in: International Political Science Review, v. 15, n. 2 (abr. 1994), pp. 106-109.

${ }^{42}$ QUEIROZ, Cristina, op. cit., pp. 57 e ss.
} 
macropolíticas intervencionistas e assistencialistas, tem-se que o Judiciário se torna partícipe da própria efetivação dos programas estatais, o que a seu turno pode acarretar consequências sistêmicas deletérias, dado os efeitos - e possíveis desequilíbrios orçamentários atinentes ao atendimento, pelo Estado, de decisões judiciais que imponham a concretização, em prol de um indivíduo ou de um grupo específico, de determinado direito que envolva alguma prestação estatal. ${ }^{43} \mathrm{O}$ Judiciário passa a influir mais diretamente nas finanças estatais, e o Estado passa a ter de destinar provisões orçamentárias para fazer frente a esse tipo de decisões, o que pode ocorrer em prejuízo do caráter universal das políticas assistencialistas ou mesmo da criação e desenvolvimento de outros projetos sociais.

No segundo caso, voltado aos princípios, abre-se espaço para a participação do Judiciário na determinação de praticamente toda e qualquer escolha política (e mesmo decisões políticas fundamentais) - ainda que não tenham ligação direta com programas estatais de intervenção nos domínios econômico e social. A possibilidade de controle do conteúdo das leis com base em critérios principiológicos insculpidos nas Constituições permite, assim, a ingerência na própria definição das escolhas legislativas relativas a questões de alta relevância para a sociedade. Qualquer política adotada que defina uma diretriz no tocante a questões sensíveis sempre envolve uma ponderação prévia do legislador acerca dos princípios que, naquele caso, devem, em tese, preponderar. Tais ponderações, assim, passam a ser objeto de questionamento judicial ainda que de maneira indireta - vez que o objeto de impugnação é o próprio ato normativo que resulta dessa ponderação -, com o que permite-se que o Judiciário as reavalie e até mesmo imponha outras escolhas que substituam aquelas do legislador. A abertura principiológica propicia, assim, a judicialização de praticamente todo e qualquer debate político e de toda e qualquer escolha legislativa.

Quanto a isso, há muito se anteviu possíveis percalços à esperada preponderância política do Executivo e do Legislativo quando haja disseminação de princípios no âmbito das Constituições. Conforme já receava Kelsen, Constituições com profusão de enunciados principiológicos propiciam ampla possibilidade de revisão constitucional pautada em meras leituras diferentes que tais normas de textura aberta permitem. Isso viabiliza, no limite, a prevalência das escolhas judiciais por meio de sua competência de controle, razão

${ }^{43}$ LOPES, José Reinaldo Lima. "Direito subjetivo e direitos sociais: o dilema do Judiciário no Estado Social de Direito", in: FARIA, José Eduardo Campos de Oliveira (org.). Direitos humanos, direitos sociais e Justiça. São Paulo: Malheiros, 1994, pp. 129 e ss. 
pela qual, defendia Kelsen, dever-se-ia limitar a quantidade e a extensão dos paradigmas constitucionais dessa natureza ao mínimo necessário à própria coesão, consistência e completude do texto constitucional. ${ }^{44}$

A despeito desse receio, e conforme já afirmado, o período posterior à Segunda Guerra Mundial põe em evidência um novo modelo constitucional, que para além de reformar a supremacia constitucional mediante institucionalização de processos de emendas mais dificultosos, buscou igualmente impor limites materiais - mormente por meio da positivação de princípios - às possibilidades de escolha do legislador infraconstitucional. ${ }^{45}$ Tais mudanças, somadas ao advento das concepções relativas ao surgimento de novos compromisso estatais na efetivação de uma igualdade material voltada à promoção de uma sociedade mais justa (fala-se, aqui, sobretudo, dos direitos econômicos e sociais e da a expansão da intervenção do Estado nesses campos), abrem novas vias de atuação do Judiciário, na medida em que permitem a rediscussão das escolhas político-legislativas mediante sua apresentação, aos Tribunais, sob o discurso jurídico-constituicional.

A análise de se tal intervenção é ou não desejável, por sua vez, depende dos próprios limites que se atribui à função de controle judicial e das concepções que se tenha a respeito do próprio papel do Judiciário frente à sociedade. Seja como for, deve ser destacado que não se está a afirmar que tais fatores levam, necessariamente, a abusos do Poder Judiciário, a qualquer tipo de usurpação de competência legiferante ou a verdadeiro descompasso na distribuição de funções entre os principais órgãos estatais. São, antes, pressupostos que permitem esse tipo de situação: a forma pela qual o Judiciário se imiscui no processo de escolhas normativas envolve igualmente outros fatores, a exemplo da política institucional do próprio órgão e da forma de estruturação do próprio sistema do controle de constitucionalidade. O que se pretende atestar, portanto, é que as mudanças aqui apontadas propiciaram a alteração na configuração das definições clássicas a respeito

\footnotetext{
44 "Mas, precisamente no domínio da jurisdição constitucional, elas [as fórmulas em que se traduzem princípios] podem desempenhar um papel extremamente perigoso. As disposições constitucionais que convidam o legislador a se conformar à justiça, à equidade, à igualdade, à liberdade, à moralidade, etc. poderiam ser interpretadas como diretivas concernentes ao conteúdo das leis. (...) Mas nesse caso a força do tribunal seria tal, que deveria ser considerada simplesmente insuportável. A concepção que a maioria dos juízos desse tribunal tivesse da justiça poderia estar em total oposição com a da maioria da população, e o estaria evidentemente com a concepção da maioria do Parlamento que votou a lei. (...) Para se evitar tal deslocamento de poder (...) a Constituição deve, sobretudo se criar um tribunal constitucional, abster-se desse gênero de fraseologia, e se quiser estabelecer princípios relativos ao conteúdo das leis, formulá-los da forma mais precisa possível.” KELSEN, Hans, op. cit., pp. 169-170.

${ }^{45}$ CAPPELLETTI, Mauro. The judicial process in comparative perspective, op. cit., pp. 185-186.
} 
das funções que cabem a cada um dos Poderes em que se divide a atividade estatal, o que por sua vez dá azo a uma série de configurações institucionais e interações entre os Poderes.

\subsubsection{A desneutralização do Poder Judiciário e a proteção de pré-compromissos}

Contribui, ainda, para a expansão judicial no campo político as próprias concepções a respeito dos objetivos que cabem à atividade jurisdicional e ao exercício do controle de constitucionalidade.

Parece inegável que as novas configurações estatais e constitucionais que se desenvolvem no século XX confrontam também o Judiciário com expectativas sociais no sentido de que seja nele depositada a incumbência de garantir o respeito, pelos demais Poderes, aos limites impostos pelos pré-compromissos insculpidos no âmbito das Constituições - e aqui se fala em sentido absolutamente genérico, o que envolve não apenas controlar a constitucionalidade das leis, mas igualmente vigiar a atividade governamental que se dissemina e tutelar alguma efetividade aos direitos fundamentais. Afinal, ao se lhe atribuir a função de conformar as atividades legiferante e, ainda que indiretamente, governamental, em especial no sentido de evitar abusos e decisões que firam o núcleo essencial dos direitos e garantias constitucionais, soa natural a consequência de que, em alguma medida, seja ele erigido à condição de corresponsável na consecução dos objetivos estatais. Nesse aspecto, a atividade jurisdicional, em especial o das Cortes Constitucionais, assume nova relevância. ${ }^{46}$

Com maiores possibilidades de atuação e reconhecendo que sua função de controle assume diferentes nuances, o Judiciário vê-se cada vez mais confortável em manejar problemas e critérios próprios à seara política (e igualmente relativos à definição de políticas fundamentais). Diz-se confortável não no sentido de que realmente passe a dominar a lógica própria desse métier, mas no contexto de que se veja inclinado a se imiscuir em tais questões - em razão do cotejo entre os instrumentos de controle que lhe são oferecidos e a concepção que se tem a respeito do papel do Judiciário na sociedade e do seu dever de proteção dos pré-compromissos constitucionais.

\footnotetext{
${ }^{46}$ CAPPELlETTI, Mauro. Juízes legisladores?. Porto Alegre: Sergio Antonio Fabris Editor, 1999, pp. 31 e
} ss. 
Conforme já afirmado, esse movimento não parece ocorrer sem alguma politização do Judiciário. Esse predicado, que em princípio tem-se por contraditório à própria ideia de um terceiro imparcial e independente ao litígio que lhe é posto a decidir, assume assim outros contornos. Afinal, tomar alguma decisão que implique consequências às escolhas legislativas feitas pelos demais Poderes - ainda que a simples invalidação normativa -, impõe sempre alguma participação no jogo político e algum juízo de adequação das decisões previamente tomadas.

A despeito desse efeito - que seria, a priori, indesejável -, verifica-se no contexto do século XX a ampla disseminação de Cortes Constitucionais, com a adoção de diferentes sistemas de controle de constitucionalidade (em diferentes graus de vinculatividade, há que se ressaltar ${ }^{47}$ ) na grande maioria dos Estados com anseios democráticos. ${ }^{48} \mathrm{O}$ controle de constitucionalidade passou a ser parte integrante de qualquer processo de democratização, sendo compreendido como elemento indissociável da proteção dos direitos e garantias constitucionais, tendo acompanhado tanto o processo de reestruturação e de surgimento de novos Estados no segundo pós-guerra, quanto o processo de superação, já na segunda metade do século XX, de regimes autoritários em Estados já existentes ${ }^{49}$ (e temos como exemplo o Brasil, cuja Constituição que guiou a redemocratização pós-ditadura ampliou largamente o sistema de controle de constitucionalidade até então existente ${ }^{50}$ ). Esse processo denota, por sua vez, a existência de confiabilidade neste Poder e algum grau de

\footnotetext{
${ }^{47}$ WALDRON, Jeremy, op. cit., pp. 1353-1359. O autor aponta sistemas de controle de constitucionalidade com diferentes graus de vinculatividade, distinguindo-os em strong e weak judicial reviews. O primeiro define sistemas em que a Corte Constitucional pode recusar-se à aplicação de lei tida por inconstitucional (invalidando-a), bem como conformar a aplicação da lei a determinada leitura dos direitos envolvidos (a exemplo sistema estadunidense), ao passo em que o segundo caracteriza sistemas em que não há tal possibilidade, ou há em amplitude muito mitigada - ainda que a Corte possa fazer escrutínio da legislação, incitando modificações legislativas por parte dos demais atores políticos, como ocorre no Reino Unido e na Nova Zelândia (cujas Cortes Constitucionais não podem recusar aplicar a lei).

${ }^{48}$ Inclusive em Estados não integrantes do grupo de grandes potenciais mundiais. GINSBURG, Tom. Judicial review in new democracies: constitutional courts in asian cases. Nova York: Cambridge University Press, 2008, pp. 7-8. O autor traz uma lista elencando mais de cinquenta Estados pertencentes ao que ele denomina de "terceira onda" da democracia (referente ao último quartel do século $\mathrm{XX}$ ), que engloba essencialmente Estados da era pós-comunista e da América Latina, em cujas novas constituições democráticas foram previstos algum modelo de controle de constitucionalidade.

49 “'Áustria desde 1945, Japão desde 1947, Itália desde 1948, Alemanha desde 1949: emergindo do pesadelo de tirania e guerra, todos esses países seguiram caminho similar no esforço de criar uma nova forma de governo, civil-libertário e democrático. Cada um deles adotou uma constituição escrita, declarou-a vinculante a todos os ramos do governo; introduziu severas limitações ao processo de emenda à constituição, protegendo, assim, as novas leis basilares dos caprichos de maiorias contingenciais; incluiu rol de direitos na constituição (...); e, por último, mas não menos importante, confiou a aplicação da Constituição, e de seu rol de direitos, a novos ou renovados tribunais judiciais, dotados de importantes garantias de independência visà-vis os poderes políticos." CAPPELLETTI, Mauro. The judicial process in comparative perspective, op. cit., pp. 185-186 (tradução própria).

${ }^{50}$ MENDES, Gilmar Ferreira. Direitos fundamentais e controle de constitucionalidade. $2^{\mathrm{a}}$ edição. São Paulo: Celso Bastos Editor, 1999, pp. 254-264.
} 
aceitação em sua atuação, ainda que diferenciada ${ }^{51}$, no processo de participação na tomada de decisões políticas. Pode-se afirmar, então, com alguma segurança, que referida politização, quando dentro de limites razoáveis, não está institucionalmente associada à perda da independência e imparcialidade que se esperam desse órgão.

Afeta, entretanto, sua neutralidade. Não aquela relativa a seu posicionamento frente aos interesses daqueles que lhe submetem alguma questão para decisão, mas a própria neutralidade institucional, no sentido de que o Judiciário não pode relegar-se a analisar e a considerar as dimensões políticas e sociais dos conflitos - sejam abstratos, no plano da constitucionalidade em tese das normas, sejam relativos a um caso concreto com base em critérios puramente legalistas.

De um lado, porque o (res)surgimento das Constituições democráticas ao longo do século $\mathrm{XX}$ teve por consequência o entendimento de que as metas, princípios e programas estatais ali veiculados deveriam ser obrigatoriamente observados tanto pelo Legislativo quanto pelo Executivo, de modo que serviriam de paradigmas de constitucionalidade para o controle realizado pelo Judiciário. ${ }^{52}$ Com isso, o Judiciário passa a ter de desvestir-se de sua blindagem quanto às possíveis implicações políticas e sociais de suas decisões - com o que se tem que tais efeitos passam a ser, desejável ou indesejavelmente, objeto de preocupação na formulação do próprio convencimento decisório.

Por outro lado, o relativo sucesso das demandas sociais por melhores condições de vida e de trabalho, refletido, já na primeira metade do século XX, na profusão de leis e enunciados constitucionais que buscavam tutelá-las no plano normativo, acabaram por impor uma nova forma de atuação ao Judiciário. Os conflitos daí surgidos deixam de poder ser resolvidos simplesmente com base numa análise retrospectiva dos fatos, por meio de aplicação de critérios formais e categorizantes próprios da legislação liberal e de sua preocupação com a garantia de uma igualdade formal (v.g., "contratante", "devedor", "inadimplemento"), que permitem certa abstração da dimensão social do conflito e

${ }^{51}$ Considerando que não participa diretamente do processo político da tomada de decisões, muito embora possa condicioná-lo pro futuro, mediante provocação, através da invalidação de atos normativo, ou, em sistemas semelhantes ao sistema clássico francês, por meio do controle preventivo de constitucionalidade, i.e., antes da promulgação da lei. Destaque-se que na França, a esse modelo de controle, realizado pelo Conseil Constitutionnel, somou-se, por força da Loi Constitutionnel du 23 juillet 2008, em vigor desde $1^{\circ}$ de março de 2010, o controle repressivo - artigos 61 e 61-1 da Constituição Francesa de 1958.

${ }^{52}$ CAPPELLETTI, Mauro. The judicial process in comparative perspective, op. cit., pp. 15-16. No mesmo sentido, a respeito da eficácia das normas constitucionais, mesmo que de cunho programático, ver: MIRANDA, Jorge. Manual de Direito Constitucional. Tomo II. $3^{\text {a }}$ edição. Coimbra: Coimbra, 1996, pp. 243 e ss. 
resultam em uma jurisdição "repressiva" (ou seja, que busca reparação com base no status quo). A era dos direitos sociais, cuja preocupação foi a de propiciar a igualdade material, exigiu um reposicionamento do Judiciário, tornando imprescindível a atuação de cunho prospectivo, comprometido com as consequências sociais da decisão e com sua correção quando se toma por parâmetro as novas metas sociais, políticas e econômicas encampadas pelo Estado. ${ }^{53}$ Conforme aponta Tércio Sampaio Ferraz Júnior, ocorre verdadeira

\begin{abstract}
desneutralização [do Judiciário, em contraposição ao posicionamento pretendido pelo Estado liberal-positivista], posto que o juiz é chamado a exercer uma função socioterapêutica, liberando-se do apertado condicionamento da estrita legalidade e da responsabilidade exclusivamente retrospectiva que ela impõe, preocupada com a consecução de finalidades políticas das quais ele não mais se exime em nome do princípio da legalidade, [e, com isso, conclui o autor que] a responsabilidade do juiz alcança agora a responsabilidade pelo sucesso político das finalidades impostas aos demais poderes pelas exigências do estado social. ${ }^{54}$
\end{abstract}

Considerando esse contexto, a politização e a desneutralização que decorrem naturalmente do desempenho da função de reforço e de resguardo (e nesse sentido também de garantir o sucesso) dos pré-compromissos estabelecidos na Constituição deixam de ser vistas como fator de descrédito do Judiciário, passando a condição de sua legitimação.

Há ainda que ser considerado que o Judiciário é alçado à condição de instituição contramajoritária, ao qual recorrem grupos minoritários quando estes veem-se prejudicados pelas escolhas políticas das maiorias. Reside aí também outro elemento de reforço institucional de sua atuação, no sentido de que o Judiciário pode mitigar críticas à sua intervenção no campo político - pelo fato de não possuir representatividade democrática nos moldes do Legislativo, por exemplo - com base na ideia de que integra seu campo de atuação resguardar e proteger as minorias políticas e sociais contra possíveis desvios de grupos majoritários em relação aos parâmetros de constitucionalidade e de efetivação de uma sociedade democrática. ${ }^{55}$ Muito embora isso não elimine tais críticas, nem mitigue os riscos de que a ponderação judicial sobre determinada opção legislativa ou ato governamental seja imprecisa e inadequada, ao menos atribiui maior confiabilidade ao

\footnotetext{
${ }^{53}$ FARIA, José Eduardo Campos de Oliveira. "Introdução: o Judiciário e o desenvolvimento sócioeconômico", in: FARIA, José Eduardo Campos de Oliveira, op. cit., respectivamente pp. 19-25.

${ }^{54}$ FERRAZ JÚNIOR, Tércio Sampaio, op. cit., p. 19.

${ }_{55}^{5}$ MENDES, Conrado Hübner. Direitos fundamentais, separação de poderes e deliberação. São Paulo: Saraiva, 2011, pp. 72-74.
} 
Judiciário na medida em que este reconhece que, eventualmente, decidir contra a maioria integra o objetivo de garantia de compromissos constitucionais.

Com isso, talvez seja inadequado ou impreciso falar-se em neutralidade política como atribuição indispensável à função judicial, ao menos enquanto esse termo reflita algum sentido de apatia institucional. O que se espera do Judiciário, em última análise, é a imparcialidade e independência frente à influência política que as instituições estatais ou grupos sociais busquem, porventura, exercer, devendo frustrar, $a b$ initio, qualquer pretensão de terceiros de influenciar e determinar suas decisões. ${ }^{56}$ Ainda quando se trate de situação meramente ideal, a imagem mostra-se necessária à confiabilidade e à legitimação em suas decisões, especialmente quando se lhe confere a competência e o poder de influenciar na tomada de decisões políticas fundamentais.

Todas essas mudanças refletem, assim, na forma pela qual o Judiciário encara o exercício de sua função de controle. Munido de instrumentos que permitem intervir na seara política e encampando parcial corresponsabilidade pelo sucesso das metas estatais sejam normativas, sejam governamentais -, acaba por se ver inclinado a participar no estabelecimento e no desenvolvimento de decisões políticas fundamentais sempre que as opções legislativas ou governamentais mostrem-se, em alguma medida, contrárias às concepções que o órgão de controle possui a respeito da ponderação de valores aplicável ao caso.

\subsection{Os atores políticos e a expansão da atuação política do Judiciário}

O controle de constitucionalidade é o instrumento por excelência para a intervenção judicial na seara política. Ele não surge, entretanto, ex nihilo. Integra, pelo contrário, a própria racionalidade do sistema jurídico em que se sustenta o Estado de Direito, sendo decorrência das concepções que se têm a respeito da supremacia constitucional e das atribuições concernentes ao Poder Judiciário, o que envolve a necessidade de se estabelecer um controle normativo que permita conformar eventuais abusos da atividade normativa. Assim, quer se estruture doutrinaria e jurisprudencialmente a partir do cotejo desses elementos, a exemplo da experiência estadunidense, quer a partir da positivação constitucional de um efetivo sistema de controle normativo atribuído ao

\footnotetext{
${ }^{56}$ FERRAZ JÚNIOR, Tércio Sampaio, op. cit., p. 16.
} 
Judiciário, o controle de constitucionalidade apenas parece sustentar-se quando haja algum grau de complacência dos demais Poderes, em especial do próprio Legislativo, cuja produção legislativa torna-se também alvo do controle. Razoável pressupor que as decisões a respeito de invalidação de decisões políticas fundamentais e da fixação de paradigmas a serem observados pro futuro se mantêm na medida em que os atores políticos tradicionais aceitem a legitimidade de suas decisões e a dimensão que assumem. Em última análise, poderiam o Executivo e o Legislativo superar a invalidação da Corte Constitucional através da reafirmação de determinada política legislativa (que por sua vez seria igualmente passível de controle, dando azo a conflitos institucionais) ou mesmo da limitação de sua competência de controle. Afinal, dado que os órgãos estatais possuem prerrogativas em decorrência de sua estruturação normativa, o controle de constitucionalidade funda-se, ao fim e ao cabo, nos próprios contornos, limitações e objetivos estatuídos pelo legislador constituinte no tocante à atuação estatal como um todo e à atividade jurisdicional em especial.

A mencionada abertura institucional à expansão da atividade judicial na seara política foi acompanhada, no contexto do século XX, pela disseminação de Constituições que contavam com um sistema de controle de constitucionalidade e com uma Corte Constitucional incumbida de seu exercício - ainda que em conjunto com outros órgãos jurisdicionais - e pelo reforço da atividade de sistemas de fiscalização normativa já existentes.

Pode-se afirmar, assim, que os atores políticos são também parte integrante do processo de judicialização da política. Em obra clássica sobre o tema, Torbjönr Vallinder, referindo-se ao processo pelo qual o Judiciário se imiscui no processo decisório político e no qual ocorre a disseminação de procedimentos judiciais para arenas políticas, define esse fenômeno:

[A] judicialização da política normalmente deve significar quer (1) a expansão do domínio das cortes ou juízes às custas dos políticos e/ou administradores, isto é, a transferência de direitos de tomada de decisão da legislatura, do gabinete, ou da administração para as cortes ou, no mínimo (2) a expansão dos métodos decisórios judiciais para fora da seara judicial propriamente dita. Em suma 
podemos dizer que a judicialização essencialmente envolve tornar algo na forma de processo judicial. ${ }^{57}$

Essa judicialização mencionada por Vallinder é reflexo direto do processo de democratização fortemente influenciado pelo fim da Segunda Guerra Mundial, de que também toma parte o próprio Legislativo. Como já afirmado, os novos anseios de democratização foram veiculados, no mais das vezes, através da constitucionalização de amplo rol de direitos e garantias fundamentais, da positivação de princípios maximizadores e também limitadores da atuação estatal e de verdadeiras metas a serem atingidas pelo Estado. ${ }^{58}$ Com isso, questões de cunho eminentemente político passam a possuir roupagem jurídico-constitucional, pelo que se transformam em verdadeiras pretensões jurídicas passíveis de serem exigidas, pela sociedade, por meio do Judiciário.

A consequência inevitável é que da política se retirou a blindagem que classicamente se lhe atribuía contra a apreciação judiciária. ${ }^{59}$ Ante o principio dogmático pelo qual todas as normas constitucionais possuem força normativa, tais direitos, garantias, princípios e metas jurídicos passam a valer como paradigmas de controle a ser exercido, em última análise, pelo Judiciário vis-à-vis a atividade dos demais Poderes. Esse controle, por sua vez, expande-se na mesma medida em que se ampliam os parâmetros de comparação das políticas estatais, que são entendidos como direitos e pretensões titularizados, em alguma medida, pelos indivíduos e pela sociedade. Abre-se, assim, sempre a possibilidade de se impugnar alguma decisão política quando se entenda contraditória com qualquer dos standards constitucionais. Consequentemente, como aponta Luiz Roberto Barroso, tem-se que "algumas questões de larga repercussão política ou social estão sendo decididas por órgãos do Poder Judiciário, e não pelas instâncias políticas tradicionais: o Congresso Nacional e o Poder Executivo"60.

Partindo do pressuposto de que os constituintes têm ciência de que suas escolhas institucionais limitarão e condicionarão as possibilidades de atuação dos governos futuros,

\footnotetext{
57 VALLINDER, Torbjörn. "When the Courts Go Marching In", in: TATE, C. Nael; VALLINDER, Torbjörn, op. cit., p. 13 (tradução própria).

${ }^{58}$ CAPPELLETTI, Mauro. The judicial process in comparative perspective, op. cit., pp. 14-16.

${ }^{59}$ E mesmo nos Estados Unidos, em que o processo de constitucionalização (isto é, de positivação de novos princípios, metas e direitos) é muito mais tímido. Nesse sentido, ver: TUSHNET, Mark. "Law and prudence in the law of justiciability: the transformation and disappearance of the political question doctrine", in: North Caroline Law Review, v. 80 (maio 2009), pp. 1229 e ss.

${ }^{60}$ BARROSO, Luiz Roberto. "Judicialização, ativismo judicial e legitimidade democrática”, p. 3, disponível in: <http://www.oab.org.br/editora/revista/users/revista/1235066670174218181901.pdf> (último acesso em 24.11.2013).
} 
presume-se que as escolhas feitas levam minimamente em consideração os possíveis desdobramentos do modelo adotado - ainda que não possam prevê-los com precisão. Cabe, assim, analisar as razões políticas que permitem justificar tais escolhas. Muito embora as hipóteses abaixo sejam analisadas separadamente, destaca-se que o surgimento de sistemas de controle e a expansão da atividade judicial decorre, no mais das vezes, da confluência desses fatores, ainda que algum possa, em certos casos, possuir notas de prevalência.

1.2.1 Fatores históricos: traumas do passado e reafirmação do compromisso democrático

Experiências estatais autoritárias e antidemocráticas revelam sobretudo a ausência de instrumentos efetivos de controle. O Governo põe em prática uma política de exclusão e de sufocamento de grupos oposicionistas, negando a diversidade idiossincrática à democracia, mediante o absoluto controle dos demais órgãos estatais - o que envolve naturalmente o Legislativo e o Judiciário. Dominando a agenda legislativa, logra positivar suas aspirações centralizadoras de poder e suas concepções acerca dos direitos e prerrogativas dos indivíduos e da coletividade - que não raras vezes marginalizam quem não comunga do ideário dominante; dominando o Judiciário, consegue atribuir legitimidade (ainda que apenas formal) a suas decisões e impedir o questionamento de seu embasamento constitucional-legal.

O autoritarismo pode florescer mesmo onde haja Constituição escrita que estabeleça limites ao poder estatal e respectivos instrumentos de controle. Basta imaginar as Constituições que Lowenstein classifica como semânticas, que visam apenas a dar uma aparência democrática a realidades estatais em que subjazem modelos de repressão. ${ }^{61} \mathrm{Em}$ vista disso, não parece correto afirmar que a previsão constitucional de balizas à atividade estatal e de vias de fiscalização garanta a esperada perenidade democrática. Ainda assim, a superação de tais regimes depende desses elementos.

\footnotetext{
${ }^{61}$ LOEWENSTEIN, Karl, op. cit., pp. 218 e ss. Nesse sentido, a respeito da classificação de Loewenstein: “[A] Constituição semântica, apesar de plenamente aplicável, é aquela cuja realidade ontológica não é senão a formalização da existente situação do poder político em benefício dos detentores do poder de fato, que dispõem do aparato coercitivo do Estado. Nesse caso, em vez de servir como limitação ao poder, a Constituição mostra-se como o instrumento para estabilizar e eternizar a intervenção daqueles dominam, de fato, o poder político." SILVA, Roberto Baptista Dias. Manual de Direito Constitucional. Barueri: Manole, 2007, pp. 23-24.
} 
A efetivação de uma ordem democrática impõe, particularmente, um compromisso que vincule os mais diversos órgãos estatais, não apenas no sentido de promoverem metas que beneficiem a sociedade e de exercerem algum autocontrole que garanta a legitimidade do exercício de suas funções e que respeite as balizas constitucionais de atuação, mas especialmente pautado na premissa de aceitarem e submeterem-se às regras do jogo positivadas. A previsão constitucional de direitos fundamentais, de objetivos a serem alcançados pelo Estado e de limites à ao exercício do poder estatal são, portanto, o ponto de partida da construção política do ideal democrático. Mas para além disso, mostra-se igualmente indispensável a institucionalização de vias de controle que possam ser acionadas quando da falibilidade da atuação política, tanto por omissão quanto a suas incumbências, quanto pelo transbordamento dos limites previstos à sua atuação.

Não por acaso, e conforme já afirmado, tornou-se lugar comum aos Estados que venceram regimes de repressão, a positivação de balizas constitucionais para a atuação estatal - ou então a ampliação do rol de limites constitucionais já existentes - e a atribuição de poderes ao Judiciário no sentido de efetivamente fiscalizar a atuação estatal em seus diferentes vieses. Isso se dá, sobretudo, mediante a criação de um sistema de controle de constitucionalidade, ou então pelo estreitamento e pelo reforço do sistema que, formalmente, já existia sob a égide do regime antidemocrático então superado. ${ }^{62}$

Uma das explicações políticas que levam, assim, à construção de um sistema que atribua maiores poderes de controle ao Judiciário reside no anseio de buscar atribuir maior estabilidade ao novo compromisso democrático que se pretende firmar. Novamente, há que se reiterar que a forma não é, a priori, suficiente. A democracia demanda engajamento político e autocontenção, qualidades que no mais das vezes estão fora das possibilidades de fiscalização efetiva dos cidadãos - que, ainda quando possam eleger seus representantes, não raras vezes veem-se diante de uma realidade em que a diversidade política e a real possibilidade de escolhas são anuladas pela hegemonia dominante. Entretanto, a ruptura de sistemas antidemocráticos deixa muito vívido na sociedade justamente a desconfiança em relação à autocontenção dos Poderes, em especial do Executivo. Com isso, a

\footnotetext{
${ }^{62}$ CAPPELLETTI, Mauro. The judicial process in comparative perspective, op cit., pp. 185-186. O autor ainda menciona (pp. 187-188) a expansão da participação do Judiciário no processo político em outros Estados, mediante a implantação de sistemas de controle de constitucionalidade, a exemplo do Chipre (em 1960), da Turquia (em 1961), de Malta (em 1964), e em especial em Estados que buscavam superar regimes antidemocráticos, a exemplo da Grécia (em 1975), de Portugal (em 1976), da Espanha (em 1978), da Iugoslávia (em 1963, ainda em sua luta política por independência da antiga União Soviética).
} 
institucionalização e a ampliação de mecanismos de controle dos atos estatais buscam servir como um ponto de partida em relação aos novos anseios sociais, como que se pretendessem estabilizar as expectativas do cidadão no sentido de que haverá, efetivamente, comprometimento político aos preceitos democráticos. Mostra-se, em suma, quase como uma resposta e uma justificativa dos atores políticos frente à sociedade, demonstrando seu empenho em favor da construção de sociedade mais justa em que não sejam permitidos abusos de poder nem desrespeito a direitos fundamentais. ${ }^{63}$

As transformações políticas que se seguiram à Segunda Grande Guerra demonstram isso. Ocorreu então verdadeira reformulação dos paradigmas constitucionais, conforme já afirmado, com a deferência de significativo poder de controle a Cortes Constitucionais que passaram a ser incumbidas da proteção daqueles pré-compromissos na medida em que se tornam, e aqui numa perspectiva institucional que leva em conta todo o Judiciário, corresponsáveis pela consecução dos objetivos estatais, dentre os quais a manutenção das premissas democráticas.

Já no contexto das ditaduras da segunda metade do século XX, Lisa Hilbink retrata a Espanha pós-franquista, em que os traumas da concentração do poder verificada ao longo da ditadura motivaram os grupos políticos envolvidos na elaboração do que viria a ser a Constituição espanhola de 1978 a estruturar limites que permitissem um amplo controle dos atos estatais, seja mediante positivação de parâmetros de atuação e de um rol de direitos fundamentais com carga semântica bastante vagas, seja pela construção de um sistema de controle de constitucionalidade pelo qual se deferiu ao Judiciário - mormente ao Tribunal Constitucional - verdadeiro poder político na definição de como a Constituição deveria ser interpretada e aplicada. ${ }^{64}$

\footnotetext{
${ }^{63}$ Ainda que isso possa, muitas vezes, resultar em constituições simbólicas, que ainda assim abrem espaço para o desenvolvimento econômico, político e social na medida em que atribui algum elemento de estabilidade ao sistema. Nesse sentido, ver: NEVES, Marcelo. "Constitucionalização simbólica", in: CANOTILHO, José Joaquim Gomes; MENDES, Gilmar Ferreira; SARLET, Ingo Wolfgang; STRECK, Lênio Luiz (coords.). Comentários à Constituição do Brasil. São Paulo: Saraiva/Almedina, 2013, pp. 71-72.

64 "Defendo que a deferência de poderes ao Judiciário pode ser explicada com precisão, e potencialmente prevista, apenas pela referência ao contexto histórico e ideacional no qual os idealizadores institucionais [institucional designers] operam. Fatores históricos e ideacionais - isto é, experiências compartilhadas, crenças, identidades, ideologias e interpretações de eventos e sequencias de eventos internos ou estrangeiros - moldam a forma pela qual os atores políticos compreendem seus interesses, formulam suas estratégias e justificam suas decisões, e são assim cruciais para explicar quando, por que, e como idealizadores institucionais escolhem por atribuir poderes às cortes (...). Eles [os idealizadores institucionais] fazem tais escolhas institucionais não apenas porque elas serão boas para si mesmos ou para o partido, mas porque elas são escolhas corretas (como em “apropriadas") para seu país. Ao delegar poder às cortes, eles não estão sempre ou apenas buscando ampliar sua própria riqueza, poder ou prestígio, mas estão às vezes fazendo o que acreditam ser necessário ao que eles prospectam como uma teoria ou um modelo de boa governança (...).
} 
A tentativa de superação de experiências antidemocráticas mostra-se, assim, como um primeiro impulso que leva os atores políticos ligados à reestruturação constitucional a optarem pela deferência de poder político ao Judiciário. Busca se lhe atribuir, dentro do contexto de aumentar as expectativas de estabilidade do novo regime que se pretende estabelecer, competência para proceder à revisão de atos estatais com base nos preceitos previstos na própria Constituição.

Sob tal aspecto sobressai, especialmente, o caráter contramajoritário dessa competência, que de pronto exerce a função pedagógica e psicológica de sinalizar às maiorias hegemônicas e aos órgão estatais que a legitimação das decisões políticas fundamentais não pode ser sustentada unicamente com base no critério democráticomajoritário.

1.2.2 O controle de constitucionalidade como 'seguro político' e como instrumento da hegemonia dominante

A hipótese levantada no item anterior denota, sobretudo, um comprometimento dos agentes políticos com uma nova ordem democrática e com a sociedade como um todo. Há uma motivação que, conquanto também vise à proteção das regras do jogo políticopartidário, projeta-se para além dessa seara.

Já se mencionou, entretanto, que a estruturação de sistemas de controle de constitucionalidade acaba por criar entraves adicionais às possibilidades de atuação dos entes e órgãos políticos, que passa a ser sempre - e ainda que em maior ou menor grau passível de fiscalização por algum órgão judicial. Há de se imaginar, assim, que muito embora o compromisso democrático permita entender a adoção de tais modelos, os constituintes se vejam também diante de uma análise dos custos políticos decorrentes da institucionalização de um sistema de controle normativo. Afinal, aos incumbidos de tomar as decisões políticas, menos restrições representa maior liberdade de atuação, de modo que a opção por menos liberdade parece justificar-se também com base nas próprias regras do

Ao menos em alguns casos, a deferência de poder às cortes não é levada a cabo unicamente, ou mesmo precipuamente, para preservar ou aumentar o poder futuro de certos indivíduos ou partidos políticos, mas sim como parte de uma resposta a uma crise social passada, trauma ou horror, (...) no desejo de criar um novo e melhor regime." HILBINK, Lisa. "The constituted nature of constituents' interests: historical and ideational factors in judicial empowerment”, in: Political Research Quarterly, v. 62, n. 4 (dez. 2009), pp. 782-783 (tradução própria). 
jogo político-partidário e não apenas em um sentimento altruístico em prol da democracia. $^{65}$

Nesse sentido, pode-se apontar duas explicações, sob o viés político, que permitem compreender a opção pela institucionalização de sistemas de controle de constitucionalidade.

O primeiro deles permite vislumbrar no controle de constitucionalidade uma forma de seguro político. Tom Ginsburg ${ }^{66}$ levanta tal hipótese ao analisar a expansão de sistemas de controle em novas democracias. Quando do surgimento de novas ordens democráticas, isto é, quando os atores políticos estão diante da necessidade de criar uma nova Constituição, a previsão e/ou a expansão do controle de constitucionalidade mostrase a escolha racional e natural tanto quanto maior seja a pulverização político-partidária naquela realidade. E, mais que a quantidade de partidos, o enfoque em verdade recai sobre a própria divisão da representatividade entre os partidos existentes, no sentido de não se poder prever que partidos se tornarão grupos majoritários e por quanto tempo conseguirão manter-se no poder. Com isso, havendo incerteza a respeito da futura posição que cada partido político deterá no contexto da divisão do poder estatal, o controle de constitucionalidade permite a ampliação das vias de acesso e de influência dos grupos oposicionistas durante os períodos de não dominância no Executivo e no Legislativo, tornando-se um mecanismo que entra no cálculo político dos agentes responsáveis pela estruturação da nova ordem democrática.

Nesse aspecto, a deferência de poder de controle ao Judiciário permite, ao menos em tese, que a oposição conteste as opções majoritárias por uma via que, muito embora possa assumir viés político - no sentido da atuação política do Judiciário e das Cortes Constitucionais -, pauta-se em balizas que deixam de fora os mecanismos de decisão próprios ao jogo político-partidário, em que muitas vezes as minorias não conseguem desempenhar verdadeira influência. Desse modo, em sistemas cujas forças políticas encontrem-se disseminadas, e no qual a manutenção no poder seja incerta, parece haver uma inclinação à criação de instrumentos de limitação da própria atividade política.

Fala-se, assim, em seguro político no sentido de que o controle de constitucionalidade e a deferência de poder político ao Judiciário permitem criar uma

\footnotetext{
${ }^{65}$ HIRSCHL, Ran. Towards juristocracy: the origins and consequences of the new constitutionalism. Cambridge: Harvard University Press, 2004, p. 39.

${ }^{66}$ GINSBURG, Tom. Judicial review in new democracies: constitutional courts in asian cases, op. cit., pp. 23 e ss.
} 
instância apartada que não apenas garanta o respeito às regras do jogo eleitoral, mas que também sirva de proteção contra eventuais medidas abusivas de grupos majoritários e permita maior ingerência e influência política por parte da oposição ou de grupos minoritários. Há, portanto, um interesse em dotar o sistema político de um elemento que milite em favor dos equilíbrio de poder entre os atores políticos envolvidos em determinada política nacional.

A segunda explicação política vê na instituição do controle de constitucionalidade uma forma de elites aumentarem seu poder político, e nesse contexto, a atribuição de poder político ao Judiciário voltar-se-ia em favor de hegemonias dominantes - que possuem, nesse caso, interesse em sua implementação. É esse o posicionamento defendido, dentre muitos, por Ran Hirschl ${ }^{67}$, que, apesar de reconhecer a relação entre insegurança política de manutenção no poder (nos moldes defendidos por Tom Ginsburg) e a criação de sistemas de controle judicial, entende que essa visão peca, dentre outras razões, por pautarse por uma análise simplista e reducionista da realidade partidária-eleitoral. ${ }^{68}$ Defende, assim, que a motivação política subjacente à sua instituição envolve a interação entre três grupos-chave:

\begin{abstract}
elites políticas ameaçadas [pelo surgimento de grupos periféricos ou pelo aumento da influência de grupos opositores] que buscam preservar ou aumentar sua hegemonia política ao isolar os processos de tomada de decisões políticas das vicissitudes do jogo democrático; elites econômicas que possam ver na constitucionalização de certas liberdades econômicas uma forma de promover uma agenda neoliberal de mercados abertos, a desregulação da economia, um antiestatismo (...); e as elites judiciais e as altas cortes nacionais que buscam aumentar sua influencia política e sua reputação internacional. ${ }^{69}$
\end{abstract}

Sob esse ponto de vista, e muito embora possa soar contraditório o fato de a hegemonia dominante buscar estabelecer balizas de atuação e formas adicionais de controle de seus atos, parece sobressair novamente um cálculo de riscos políticos, de modo que o grupo majoritário prefira estipular mecanismos que $(i)$ viabilizem novas vias de legitimação de suas escolhas, que podem ser ratificadas pelas Cortes Constitucionais cujos membros são (ou podem ser) escolhidos pelo próprio grupo dominante, e (ii) permitam maior estabilidade à suas políticas legislativas, dado que qualquer modificação futura, se feita por um grupo oposicionista que se torne majoritário, poderá ter sua

\footnotetext{
${ }^{67}$ HIRSCHL, Ran. Towards juristocracy: the origins and consequences of the new constitutionalism, op. cit., pp. 38 e ss.

${ }^{68}$ Idem, ibidem, p. 42.

${ }^{69}$ Idem, ibidem, p. 43 (tradução própria).
} 
constitucionalidade contestada - havendo aqui, portanto, alguma semelhança com a ideia de seguro político.

Hirschl usa como exemplo clássico, o caso de Israel, em que os Ashkenazi, burguesia secular dominante na política por décadas, vê seu poder diminuir ao longo da década de 1980 pelo paulatino crescimento de grupos políticos periféricos, passando, com isso, a arquitetar junto às elites econômicas dominantes a institucionalização de um efetivo sistema de controle de constitucionalidade pautado também na positivação - em âmbito constitucional - de uma série de direitos fundamentais que servissem de baliza para a fiscalização judicial. Fala-se, assim, na importante reforma constitucional israelense de 1992, que remodelou o papel do Judiciário, dotando-o de poder e influência política mediante o reforço do sistema de controle de constitucionalidade e a positivação de um novo rol de direitos constitucionalizados, reforma esta que foi implementado por elites das searas política (o que inclui o grupo partidário então dominante), econômica, acadêmica e judicial. A ideia, segundo o autor, era a de tentar blindar a ideologia do grupo dominante, transferindo a discussão de questões sensíveis do campo eminentemente político para a seara judicial. $^{70}$

Em ambas as hipóteses, a opção política pela implementação e expansão do controle de constitucionalidade entra no cálculo político a ser realizado pelos agentes envolvidos na conformação das mais diversas ordens constitucionais. Com efeito, a institucionalização de um terceiro órgão competente para dirimir conflitos de constitucionalidade - com todas as implicações que decorrem de se atribuir tal poder ao Judiciário - retira do campo eminentemente político uma série de discussões, que passam a ser travadas com base em critérios formalísticos-legais próprios ao Direito. Conforme se buscou apontar, essa opção, muito embora possa se reverter em prejuízo do Legislativo e do Executivo, leva em conta uma ponderação de riscos políticos pelos próprios representantes, relativa a possíveis mudanças no cenário partidário-eleitoral - o que por sua vez acarreta possibilidade de mudanças às próprias políticas a serem adotadas em determinada sociedade. Sob esse ponto de vista, e conquanto o Judiciário, uma vez confortável com o exercício da função de controle, passe a atuar com base em premissas próprias - que muitas vezes se distanciam da intenção dos agentes que estabeleceram essa competência -, tem-se que a expansão do poder político do Judiciário mostra-se como um

\footnotetext{
${ }^{70}$ HIRSCHL, Ran. "The political origins of judicial empowerment through constitutionalization: lessons from Israel's constitutional revolution”, in: Comparative Politics, v. 33, n. 3 (2001), pp. 322-323.
} 
elemento que se volta em favor do embate pelo poder estatal, visando a dotá-lo de maior equilíbrio entre os envolvidos, e que decorre de escolhas racionais dos próprios políticos envolvidos.

\subsubsection{A deferência de questões políticas controversas}

Quer no que diga respeito a princípios e regras atinentes à atuação dos órgãos estatais, quer no que diga respeito aos direitos fundamentais dos indivíduos, as Constituições possuem por escopo apenas definir diretrizes que pautarão o desenvolvimento político, econômico e social. Não por acaso, em muitas matérias estabelecem regramentos de textura aberta, que comportam uma série de conformações e ponderações pelo legislador e pelo governante responsáveis por guiar tal desenvolvimento. Constata-se, assim, que o constituinte relegou ao legislador ordinário a definição de uma série de políticas fundamentais, que podem ser estruturadas com base em inteligências diversas que se podem extrair da ponderação daqueles preceitos plurivalentes.

Há pelo menos duas razões que permitem explicar esse modo de ser. Em primeiro lugar, há que se considerar que, servindo de fundamento último para a validade das normas jurídicas, caso a Constituição seja pormenorizada a ponto de definir, de antemão, uma ampla gama de ponderações e aplicações práticas relativas aos princípios que estabelece, acabaria por engessar e limitar excessivamente o viés evolutivo e atualizador da produção legislativa. No mais, deve ser igualmente compreendido que a promulgação de novas Constituições ocorre, no mais das vezes, em momentos políticos delicados em que são chamados ao consenso uma diversidade de grupos e interesses políticos, sendo certo ser muito mais fácil chegar-se a algum acordo quanto a termos abstratos que quanto a aplicações específicas de determinadas premissas à realidade social. A abstração das normas constitucionais, assim, favorece não apenas o desenvolvimento normativo e governamental e a atividade legislativa, mas igualmente permite que se atinja o consenso mínimo necessário relativo ao ponto de partida de uma nova ordem democrática.

Essa dificuldade de consenso, por sua vez, permite constatar que há diversas questões em que os atores políticos preferem não se imiscuir, justamente por serem sensíveis e controversas, de modo que envolvem, inevitavelmente, custo político frente à sociedade e ao eleitorado. Deixadas em aberto na Constituição, muitas vezes tampouco há 
certeza sobre se o legislador infraconstitucional, ou mesmo o constituinte de reforma ou revisão, possuirá cometimento político em tomar alguma posição a respeito, dada a grande divisão de opiniões e de ideologias a respeito - novamente, entra no cálculo o custo político envolvido. E pode mesmo haver matérias que, não pensadas ou debatidas pelos constituintes, tornem-se relevantes em momento posterior do desenvolvimento social e que exijam, igualmente, algum posicionamento normativo a respeito.

A deferência de poder político ao Judiciário mostra-se, nesse contexto, uma alternativa para os agentes políticos, uma válvula de escape que lhes permite relegar a outra seara a definição dessas políticas. Muito embora haja muita discussão e muito questionamento - partindo do próprio Legislativo e do Executivo - quanto à participação judicial na adoção de alguma decisão no tocante a essas questões sensíveis - afinal, não seria esta a seara adequada para tomada de posicionamentos de cunho normativo quanto a decisões políticas delicadas -, fato é que a intervenção judicial permite que alguma escolha seja feita de modo que o legislador se exima de responsabilidade direta quanto à definição da política sob discussão - ainda que, indiretamente, possa vir a ser cobrado quanto à inércia que resultou na necessidade de participação do Judiciário na definição da matéria.

Nael Tate pondera que a estruturação de sistemas de controle de constitucionalidade representa também uma escolha racional do constituinte ao antecipar essa problemática, de modo a permitir que algumas decisões políticas essencialmente sensíveis sejam transferidas para o Judiciário, poupando-se, assim, dos custos políticos decorrentes de qualquer posição que seja adotada a respeito (e, nesse aspecto, a “delegação" voluntária ocorreria especialmente no campo da proteção de direitos fundamentais). ${ }^{71}$ Corroborando essa ideia, Mark Graber também aponta uma intenção da coalizão dominante de retirar algumas discussões políticas muito controvertidas da realidade política-eleitoral, transferindo-as para âmbito judicial, no qual se revestem do discurso jurídico-formal e diminuem os custos da decisão ao final estabelecida. Esse fenômeno se tornaria ainda mais expressivo quando o grupo dominante tem motivos para acreditar que o Judiciário - em especial a Corte Constitucional - decidirá de acordo com as concepções políticas que, embora apoiem, não podem fazê-lo publicamente sem risco à coalizão ou à manutenção do apoio político dos eleitores. ${ }^{72}$

\footnotetext{
${ }^{71}$ TATE, C. Nael, "Why the Expansion of Judicial Power?”, in: TATE, C. Nael; VALLINDER, Torbjörn, op. cit., p. 32. No mesmo sentido, ver: TUSHNET, Mark. "Judicial power and political power: some observations on their relations", in: Fordham Law Review, v. 75, n. 2 (2006), pp. 759-762.

${ }^{72}$ GRABER, Mark A. "The nonmajoritarian difficulty: Legislative deference to the Judiciary", in: Studies in
} 
Conquanto os atores políticos contestem a atuação judicial na arena política, ainda mais quando se trate de questões políticas sensíveis, em alguma medida o Legislativo e o Executivo se beneficiam, politicamente, desse tipo de intervenção. Ao escolherem relegar às Cortes Constitucionais a definição de algumas matérias - em uma somatória da atribuição de competência para julgarem tais questões e da falta de definição legislativa no tocante a determinada matéria -, parece claro que acabam também por assumir os riscos de sobrevir algum posicionamento que destoe das ideologias do partido ou da coalizão majoritária. Ainda assim, considerando o contexto envolvido na discussão legislativa dessas matérias, do ponto de vista dos legisladores, a ampla expansão de poder judicial para se imiscuir em tais questões demonstra que tais riscos mostram-se compensados pela transferência e diluição dos custos políticos junto ao eleitorado.

\subsection{O Judiciário na arena política}

As mudanças dos paradigmas constitucionais, a renovação das concepções acerca do papel desempenhado pelo Judiciário junto à sociedade e o alargamento normativo da função de controle de constitucionalidade nos ordenamentos jurídicos abrem espaço para que o Judiciário passe a atuar no âmbito da definição de políticas estatais. Os elementos apontados nos capítulos anteriores são, por assim dizer, os pressupostos que viabilizam e permitem compreender a expansão do poder político do Judiciário, mas que a priori não permitem prever as formas pelas quais o Judiciário - em especial, as Cortes Constitucionais - lançarão mão de suas competências. Ao passarem a integrar o cenário político - ainda que blindados pelo raciocínio jurídico-formal - o Judiciário expõe-se a constantes interações com o Legislativo, e é do conjunto dessa relação que se estabelece que um e outro Poder testam os limites de suas competências e estabelecem os parâmetros de sua atuação. Torna-se relevante, assim, na compreensão do fenômeno e na análise de sua extensão, avaliar tanto a política institucional das Cortes Constitucionais - principais atores desse contexto, dado que são responsáveis pela tomada de decisões de ampla abrangência normativa - quanto a reação dos atores políticos. 


\subsubsection{A relevância da política institucional do Judiciário}

Ao se falar, no contexto do presente estudo, em política institucional do Judiciário, faz-se referência ao modo pelo qual seus órgãos, em especial a Corte Constitucional, põem em prática as atribuições que lhes são conferidas pelo arranjo constitucional do Estado quanto à função de controle. Conforme já afirmado, a ampliação de paradigmas constitucionais, a expansão do rol de direitos fundamentais e o alargamento das competências relativas ao controle de constitucionalidade abrem caminho para uma atuação mais incisiva no campo da definição de políticas legislativas, mediante a revisão das escolhas (ou das omissões) tomadas pelos agentes políticos. Entretanto, é a forma como o Judiciário encampa e coteja esses elementos vis-à-vis seu papel no Estado e na sociedade que permite vislumbrar diferentes nuances quanto à sua forma de atuação e à sua efetiva participação na política estatal.

Em suma, fala-se, enquanto dois extremos, em políticas de autocontenção e de ativismo judicial.

O primeiro traduz um posicionamento do Judiciário em que este avalia e emprega com cautela o exercício da função de controle. Muito embora a declaração de inconstitucionalidade de uma norma sempre imponha a prevalência de uma ponderação e de um sopesamento feito pelo Judiciário em prejuízo daquele feito pelo Legislativo, um Judiciário que adote a autocontenção busca sempre ater-se aos limites negativos de sua função de controle, no sentido de apenas invalidar uma decisão legislativa quando entenda que esta realmente não se coaduna com o sistema constitucional. Evita-se, com isso, juízos a respeito de qual seria a melhor política a ser adotada, como ocorre quando o Judiciário reconhece uma inconstitucionalidade que não é patente, mas apenas reveste sua avaliação acerca da melhor solução normativa para o caso, bem como no sentido de impor uma nova e diferente política que substitua aquela que é invalidada.

No outro oposto, tem-se o ativismo judicial que, conforme aponta Elival da Silva Ramos, retrata "a ultrapassagem das linhas demarcatórias da função jurisdicional, em detrimento principalmente da função legislativa, mas, também, da função administrativa e, até mesmo, da função de governo"73, tratando-se, pois, de "descaracterização da função

\footnotetext{
${ }^{73}$ RAMOS, Elival da Silva. Ativismo Judicial: parâmetros dogmáticos. São Paulo: Saraiva, 2010, pp. 116.
} 
típica do Judiciário, com incursão insidiosa sobre o núcleo essencial de funções constitucionalmente atribuídas a outros Poderes." 74

O ativismo judicial, em última análise, traduz a atuação proativa do Judiciário na definição de políticas estatais, pela qual, a pretexto de realizar o controle de constitucionalidade das normas (que em tese possui caráter negativo, de veto) acaba por definir, impor e estabelecer expressamente novas políticas de observância obrigatória para os demais Poderes. Obrigatórias, por um lado, em razão da definitividade e da vinculatividade de suas decisões perante os demais órgãos estatais e os particulares (a menos quando se trata de controle abstrato de normas ou, em sistemas como o estadunidense, em casos concretos decididos pela Suprema Corte); de outro, pelo fato de sinalizar a toda a sociedade qual o entendimento da Corte sobre determinada questão, o que acaba por impedir - ou, ao menos, desincentivar - a adoção de novas políticas que contrariem a ratio decidendi que embasou a "nova política judicial", pelo simples fato de que serão igualmente passíveis de controle.

Apesar de fenômeno relativamente novo na realidade brasileira, o ativismo judicial foi há muito verificado e retratado pela doutrina estrangeira, em especial com base na atuação da Suprema Corte estadunidense na segunda metade do século XX. Ressalte-se que nos países de tradição de common law, o ativismo apresenta-se menos perceptível, em razão dos corolários normativos-institucionais próprios do modelo de stare decisis. ${ }^{75}$ Entretanto, o controle de constitucionalidade estadunidense nos dá clássicos exemplos de ativismo. Pari passu à institucionalização de seu papel político e de sua participação na definição de políticas legislativas no tocante ao federalismo e às competências dos três Poderes - a exemplo das consequências (i) da criação do princípio dos poderes implícitos para a competência legiferante do Congresso e (ii) da delimitação (oscilante ao longo do século XX) a respeito da competência do Congresso em regular questões atinentes a comércio interestatal $^{76}$-, a Suprema Corte dos Estados Unidos adotou, na segunda metade

\footnotetext{
${ }^{74}$ Idem, ibidem, p. 117.

${ }^{75}$ Idem, ibidem. pp. 104-110. Em síntese: "Se o ativismo judicial, em uma noção preliminar, reporta-se a uma disfunção no exercício da função jurisdicional, em detrimento, notadamente, da função legislativa, a mencionada diferença de grau permite compreender porque nos ordenamentos filiados ao common law é muito mais difícil do que nos sistemas da família romano-germânica a caracterização do que seria uma atuação ativista da magistratura, a ser repelida em termos dogmáticos, em contraposição a uma atuação mais ousada, porém ainda dentro dos limites do juridicamente permitido." Idem, ibidem, p. 107.

${ }^{76}$ Ao longo do século XX, a Suprema Corte admitiu diferentes extensões ao que se poderia considerar como "comércio interestadual", redefinindo, a cada momento, parâmetros balizadores desse termo, com o que alargou ou restringiu a competência do Congresso. A esse respeito, ver: TUSHNET, Mark. The new constitutional order, op. cit., pp. 36 e ss.
} 
do século XX, uma política institucional ativista ao tratar de algumas questões ligadas à proteção de direitos fundamentais: decisões determinando a proibição da segregação racial em escolas públicas (Brown v. Board of Education ${ }^{77}$ ), o reconhecimento da liberdade do uso de contraceptivos (Griswold v. Connecticut ${ }^{78}$ ) e o reconhecimento da liberdade de se submeter a práticas abortivas (Roe v. Wade ${ }^{79}$ ) são alguns desses exemplos.

O neoconstitucionalismo, por sua vez, encampa uma nova forma de se entender o Direito Constitucional e o papel a ser desempenhado pelo Judiciário, em prejuízo, é bem verdade, da atividade legislativa. Consoante aponta Luis Pietro Sanchís, o neoconstitucionalismo baseia-se, basicamente, em cinco postulados, quais sejam:

mais princípios que regras; mais ponderação que subsunção; onipresença da Constituição em todas as áreas jurídicas e em todos os conflitos minimamente relevantes, no lugar de espaços isentos em favor da opção legislativa ou regulamentar; onipotência judicial em vez de autonomia do legislador ordinário; e, por último, coexistência de uma constelação plural de valores. ${ }^{80}$

Com isso, e especialmente em ordenamentos com profusão de princípios e normas de textura aberta em sua Constituição (todos com força normativa), uma supervalorização dessa visão neoconstitucionalista pode levar a situações em que a Corte Constitucional, ao realizar o controle de constitucionalidade, simplesmente ignora o valor preponderante previamente ponderado pelo legislador (e positivado na norma impugnada), alterando qual desses valores deve sobressair, mesmo quando a escolha anteriormente feita pelo legislador não incorra em patente inconstitucionalidade. ${ }^{81}$

\footnotetext{
${ }^{77}$ Caso 347 U.S. 483 (1954).

${ }^{78}$ Caso 381 U.S. 479 (1965).

${ }^{79}$ Caso 410 U.S. 113 (1973).

${ }^{80}$ SANCHÍS, Luis Pietro. "Neoconstitucionalismo y ponderacion judicial” in: CARBONELL, Miguel (ed.). Neoconstitucionalismo(s). $4^{\mathrm{a}}$ edição. Madri: Trotta, 2009, p. 131 (tradução própria).

${ }^{81}$ Humberto Ávila aponta que a visão neoconstitucionalista pode levar a alguns graves problemas, quais sejam: (i) o antiescalonamento da ordem jurídica, vez que, se tudo pode ser resolvido com base em princípios constitucionais, há um esvaziamento dos demais níveis normativos (que inegavelmente desempenham funções indispensáveis no ordenamento); (ii) o esvaziamento da função legislativa, tendo em vista a possibilidade de o Judiciário suplantar a ponderação feita pelo legislador por uma nova ponderação, que acredite ser mais adequada; (iii) a insegurança jurídica causada pelo subjetivismo a que essa visão leva, já que há o esvaziamento das regras, e portanto, de sua função de orientação das condutas humanas, que é substituída pela ponderação caso a caso feita pelo magistrado. ÁVILA, Humberto Bergmann. "Neoconstitucionalismo: entre a 'Ciência do Direito' e o 'Direito da Ciência'", in: Revista Eletrônica de

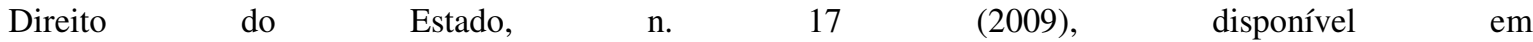
<http://www.revistas.unifacs.br/index.php/redu/article/download/679/507>, pp. 7-9 (último acesso em 20.10.2013).
} 
Esses dois extremos, a autocontenção e o ativismo judicial, permitem compreender o quão diversa pode ser a forma pela qual o Judiciário encampa o exercício de sua função de controle.

Considerando a franca expansão dos pressupostos que institucionalizaram e firmaram sistemas de constitucionalidades em diversos Estados, é o próprio Judiciário quem dá a nota de sua atuação no campo político. Muito embora haja diversas variáveis que influam nesse processo (a exemplo da forma de escolha de membros das Cortes Constitucionais, a formação jurídica dos magistrados e a situação momentânea por que passa determinada sociedade), a experiência estrangeira permite vislumbrar que a maior participação judicial se desenvolve num crescente. Num momento inicial, de sedimentação da legitimidade de sua função de controle perante os demais Poderes e a sociedade, o Judiciário tenderia a ser mais contido, e a tratar de assuntos menos polêmicos. Paulatinamente, e à medida que se veja mais confortável e conte com respaldo para dar maior abrangência aos possíveis efeitos do controle de constitucionalidade, o Judiciário passaria a se imiscuir mais fortemente em questões mais sensíveis e a atuar de modo mais proativo, como se fora verdadeiro partícipe da definição das macropolíticas estatais.

Nesse sentido, aponta Martin Shapiro ${ }^{82}$ que, fundamentalmente, o controle de constitucionalidade é construído para lidar com questões institucionais dentro do contexto do federalismo e da separação de Poderes. A questão da proteção de direitos fundamentais e a assunção da corresponsabilidade em sua efetividade apenas ocorreria em momento posterior, quando a atuação e a influência da Corte Constitucional no âmbito político já estivesse de algum modo legitimado. Esse fenômeno ocorreria mesmo em Estados que passaram por processos de democratização com a instituição de vasto rol de direitos e garantais (e nos quais, portanto, se presumiria que a função primordial do controle de constitucionalidade seria a de resguardar sua eficácia - o autor coloca Israel como exceção, i.e., em que o controle de constitucionalidade surge fundamentalmente para a proteção de direitos fundamentais). Fundamenta-se esse entendimento com base na ideia de que a proteção de direitos constitucionais pode envolver mais fortemente a imposição de políticas contramajoritárias, o que demandaria assunção de maiores riscos institucionais por parte das Cortes e do Judiciário como um todo, ao contrário de conflitos sobre federalismo e separação de Poderes que, conquanto envolvam alguma tomada de decisão,

${ }^{82}$ SHAPIRO, Martin. "The success of judicial review and democracy", in: SHAPIRO, Martin; STONE SWEET, Alec. On Law Politics and Judicialization. Nova York: Oxford University Press, 2002, pp. 149 e ss. 
lidam essencialmente com o estabelecimento de limites à atuação dos órgãos e entes estatais entre si.

É claro que ainda quando adote um posicionamento mais contido, sua atuação em sede de controle de constitucionalidade sempre acarretará alguma influência na escolha e na definição de políticas. Ainda assim, é a forma pela qual o Judiciário interpreta e aplica as competências que lhe são atribuídas pelo sistema constitucional - que pode evoluir conforme o controle de constitucionalidade se sedimenta em cada realidade estatal - que acaba, ao fim e ao cabo, por definir seu grau de participação na definição de políticas legislativas fundamentais. Conforme já se afirmou, as variáveis são muitas, e são muito mais pragmáticas que teóricas, dado que mesmo sistemas semelhantes podem apresentar graus diversos de intervenção e participação judicial.

\subsubsection{A reação dos atores políticos à expansão das Cortes Constitucionais}

Conforme já se apontou, o controle de constitucionalidade surge como escolha política dos legisladores, quaisquer que sejam suas motivações mediatas e imediatas. Muito embora a forma de seu desenvolvimento possa escapar à previsão dos constituintes, trata-se de uma competência que precisa ser exercida dentro de limites que se mostrem aceitáveis pelos próprios legisladores - que, indiretamente, têm sua produção normativa sob o crivo do Judiciário. Daí se afirmar que algum grau de complacência do Legislativo é indispensável tanto à estruturação quanto ao desenvolvimento da função de controle normativo pelo Judiciário. O controle de constitucionalidade sempre dará azo ao surgimento de conflitos institucionais, dado que é razoável supor que o Legislativo não raras vezes verá na intervenção do Judiciário - a despeito do contexto de seu desenvolvimento - uma ingerência indesejada em seu campo de atuação. O elementochave, portanto, está na busca de um equilíbrio, e a crescente proliferação de decisões de Cortes Constitucionais em questões políticas fundamentais denota que o Judiciário vem testando junto aos demais Poderes os limites da aceitabilidade do exercício do poder de controle. Não é difícil imaginar, entretanto, que o Legislativo, entendendo que o Judiciário vem ultrapassando os limites de sua competência, busque limitar ou atenuar o exercício do controle de constitucionalidade. 
Nessa discussão, o pressuposto democrático possui especial importância. A análise acerca da aceitação ou de eventual superação e limitação da influencia do Judiciário no controle e na definição de políticas adotadas pelos demais Poderes assume relevância maior quando se está diante de um sistema em que uma das premissas basilares determine o respeito às regras do jogo. Em regimes antidemocráticos, o controle de constitucionalidade somente se sustenta na medida em que siga as diretrizes das elites hegemônicas e, com isso, esvai-se seu caráter protetivo e sua função de efetivo controle de pré-compromissos constitucionais. ${ }^{83} \mathrm{O}$ uso da força, em última análise, coíbe a potencial amplitude do instrumento de controle.

No contexto democrático, por sua vez, dado o indiscutível (e legítimo) interesse dos demais Poderes em limitar a potencial dominância política do Judiciário, a conjugação entre o quantum de deferência por parte desses Poderes e a previsão de instrumentos de limitação da influência e do determinismo judicial na definição de políticas legislativas envolve discussões e busca de alternativas que estejam pautadas na manutenção da ordem, na impossibilidade do uso coercivo de força e no respeito às regras do jogo. A institucionalização de instrumentos (não previstos inicialmente pela Constituição) de contenção do poder das Cortes Constitucionais, como resposta à desenfreada interferência no campo político, parece sempre trazer em si o estigma antidemocrático, como se fora, em qualquer hipótese, uma forma de as hegemonias dominantes limarem um dos meios de controle à disposição das minorias, razão pela qual os mecanismos de contenção devem estar fundamentalmente ancorados em premissas democráticas, ainda mais quando o respectivo Judiciário já tenha se tornado politizado e goze de ampla legitimação social.

Ainda assim, é compreensível que o Legislativo busque, em alguma medida, e a depender do grau de ativismo do Judiciário, conter a expansão da intervenção no último na função relativa à definição de políticas estatais. Mais que isso, tal medida pode até mesmo possuir por escopo readequar o equilíbrio entre os Poderes quando a atuação do Judiciário venha impondo a preponderância desse Poder no campo político.

Diante desse contexto, Tom Ginsburg aponta quatro possíveis reações do Legislativo às decisões das Cortes Constitucionais

\footnotetext{
${ }^{83}$ Conforme destaca Tom Ginsburg, o "controle de constitucionalidade é quase exclusivamente associado com governos democráticos". GINSBURG, Tom. Judicial review in new democracies: constitutional courts in asian cases, op. cit., p. 69 (tradução própria).
} 
(i) concordar com a decisão e acatar o posicionamento do Judiciário; (ii) ignorar a decisão e esperar que a tentativa de se fazê-la cumprir não será eficaz; (iii) buscar superar a decisão por meio de emenda constitucional ou - em sistemas em que isso seja possível - recusando-se a aceitá-la e a aplicá-la; e (iv) atacar o Judiciário - a Corte Constitucional, em suma - como instituição, buscando reduzir sua competência para casos futuros. ${ }^{84}$

A primeira hipótese retrata uma situação de complacência do Legislativo e, de certo modo, traduz a normalidade que se espera do equilíbrio entre os Poderes. Os demais Poderes acatarão as decisões do Judiciário enquanto este se mostre atuante dentro dos limites de competência que lhe foi conferida. Parece ser também este o caso quando as Cortes Constitucionais, muito embora adotando uma política mais ativista, se imiscuem em questões sensíveis em que o Legislativo não consiga se posicionar em razão dos custos políticos envolvidos. Nessa hipótese, conquanto possa transparecer uma atuação judicial que extrapole os limites tradicionais do controle de constitucionalidade, o Legislativo tende a aceitá-la pelo fato de que alguma decisão precisa ser tomada - e será tanto mais aceita quanto mais a decisão se aproximar da opinião do grupo político dominante, ainda que este não possa defendê-la publicamente sem riscos à coalizão ou à fidelização do eleitorado.

O segundo caso envolve um início de crise institucional. Por qualquer motivo que seja, o Legislativo, ao ignorar a interpretação fixada, sinaliza que o controle normativo judicial toma rumos indesejáveis pela maioria política dominante. Ainda que a motivação para tanto seja apenas um desconforto e uma contrariedade do grupo majoritário quanto à interpretação e à política fixadas pelo Judiciário, fato é que a inobservância da decisão aponta um entendimento de que o Judiciário ultrapassou alguma barreira em sua competência e adentrou, para além do desejável, no campo político.

A terceira situação pode envolver dois contextos diversos. Em um primeiro, podese imaginar que o controle de constitucionalidade reconheceu que determinada política legislativa não pode persistir no sistema jurídico em razão da inexistência de alguma premissa constitucional que a embase ou que a permita - premissa essa que poderia ser admissível. Aqui, o Judiciário reconhece a possibilidade, em tese, da política, mas desde que o contexto constitucional fosse outro. Nesse caso, a tentativa de reverter a decisão por meio de reforma constitucional não ataca nem confronta, diretamente, a ratio decidendi da Corte Constitucional, mas sim busca abrir caminho para a legitimidade constitucional da

\footnotetext{
${ }^{84}$ Idem, ibidem, p. 77 (tradução própria).
} 
política pretendida - que pode vir posteriormente a ser reeditada, com base nas novas premissas constitucionais.

Em um segundo cenário, pode-se vislumbrar um embate institucional mais direto, em que a Corte Constitucional invalide uma norma por entender que a política legislativa subjacente é insustentável e que não seria admissível uma alteração constitucional - dentro da lógica do sistema vigente - que pudesse dotá-la de adequado embasamento. Nessa hipótese, a interpretação fixada é mais profunda, pois estabelece verdadeiros limites ao próprio sistema constitucional. Também em tais casos seria possível imaginar que o Legislativo buscasse emendar a Constituição, de modo a, ao menos formalmente, permitir a reedição da política invalidade (basta se imaginar uma emenda que permitisse, no contexto da decisão da Suprema Corte estadunidense no caso Brown v. Board of Education $^{85}$, a segregação racial em escolas públicas). A própria constitucionalidade da emenda poderia ser questionada ${ }^{86}$, o que mostra que, em tais situações, o embate entre a intenção do Legislativo e o controle do Judiciário envolve um conflito normativo de patamar mais elevado, relativo aos próprios limites do sistema constitucional. Mesmo quando não surta efeitos práticos, a tentativa - ou ameaça - de reação do Legislativo por meio de alteração dos paradigmas constitucionais pode sinalizar ao Judiciário o descontentamento e a irresignação do primeiro quanto à intervenção do último, com o que pode estimular uma readequação dos limites da participação política do Judiciário. ${ }^{87}$

A última das possíveis reações aponta a um desgaste institucional mais elevado. $\mathrm{O}$ Legislativo, entendendo haver usurpação de suas competências pelo Judiciário, busca atacar o cerne da atuação política do último, qual seja, a própria extensão de sua competência de controle, mormente por via de emenda à Constituição - ao menos nos Estados em que o controle de constitucionalidade vem ali formalizado. Exemplo brasileiro recente nesse sentido é a proposta de emenda constitucional n. 33, de 2011, que busca, dentre outras medidas, limitar a competência do Supremo Tribunal Federal em ações

\footnotetext{
${ }^{85}$ Caso 347 U.S. 483 (1954).

${ }^{86}$ Muito embora, conforme destaca Oscar Vilhena Vieira, a Suprema Corte estadunidense mostre, na prática, reticência em avaliar, no mérito, a constitucionalidade de emendas à Constituição. VIEIRA, Oscar Vilhena. $A$ Constituição e sua reserva de Justiça (um ensaio sobre os limites materiais do poder de reforma), op. cit., pp. 141 e ss.

${ }^{87}$ GINSBURG, Tom. Judicial review in new democracies: constitutional courts in asian cases, op. cit., p. 79. $\mathrm{O}$ autor cita a atuação política no Congresso estadunidense que buscou superar, por emenda constitucional, a decisão dada pela Suprema Corte no caso Roe vs. Wade, que teve por efeito prático a liberação de práticas abortivas. Ainda que o Congresso não tenha obtido sucesso nessa empreitada, verificou-se, posteriormente, que a Suprema Corte passou a tolerar alguma regulação estadual sobre o aborto, o que denotaria certa efetividade em ameaças políticas de desconsideração das decisões da Corte com base nos instrumentos democráticos de reforma constitucional.
} 
diretas de inconstitucionalidade que tenham por objeto emendas à Constituição, submetendo a decisão de mérito proferida a um controle posterior pelo próprio Congresso Nacional. Ainda que haja incerteza quanto ao sucesso da aprovação dessa proposta, tem-se aí uma reação congressista aos recentes casos de ativismo do Supremo Tribunal Federal, denotando o desconforto do Legislativo no tocante aos limites de competência que a própria Corte vem atribuindo a si mesma. Há, entretanto, casos mais extremos, a exemplo da Malásia, que acabou por resultar em medidas inconstitucionais e absolutamente autoritárias. Reagindo contra decisões da Corte Constitucional, o partido dominante iniciou um processo de impeachment do presidente da Corte perante um tribunal especial. Quando então cinco dos juízes desse tribunal, que também pertenciam à Corte, votaram a favor de seu presidente, foram todos alvos de impeachment. ${ }^{88}$

As reações dos atores políticos permite compreender o estágio não apenas do próprio desenvolvimento democrático - em especial porque medidas retaliatórias extremas denotam uma não aceitação ao diálogo institucional -, mas igualmente da evolução, em cada Estado, do sistema de controle de constitucionalidade e dos papéis que cada um dos Poderes encampa na realização das metas estatais. A reação do Legislativo e mesmo do Executivo mostra-se como algo natural sempre que estes entendam haver um desequilíbrio no desempenho das funções de controle pelo Judiciário, servindo como um indicativo da necessidade de se readequar os limites de sua atuação, ainda que seja mediante a adoção de políticas menos ativistas e mais de autocontenção. Reitere-se que medidas que ataquem diretamente o Judiciário envolvem sempre uma delicada análise de custos políticos e institucionais. Tentativas de um Poder em reduzir as competências de outro - ainda que se busque apenas readequar os limites dessa competência, quando venha sendo indevidamente extrapolada - vêm sempre revestidas de uma aparência antidemocrática, o que não raras vezes deflagra um conflito entre os Poderes. A vasta gama de possibilidades de interações institucionais, de ação do Judiciário e de reação dos demais Poderes, mostra,

\footnotetext{
${ }^{88}$ Idem, ibidem, p. 80. O autor menciona ainda na mesma obra dois outros casos emblemáticos. Primeiro, a situação da Índia na década de 70 em que, após Gandhi decretar um ato emergencial em 1975, o Parlamento aprovou emenda constitucional que proibia a Corte Constitucional de realizar controle de emendas constitucionais futuras, o que acabou sendo compreendido como uma ameaça à política que a instituição vinha adotando e resultou em uma maior submissão às vontades parlamentares. Expirada a situação de emergência, entretanto, verificou-se que a Corte passou a atuar de maneira ainda mais incisiva na política nacional, inclusive rejeitando a constitucionalidade da emenda que limitava seu poder de controle quanto a emendas constitucionais (p. 97). Por fim, o caso russo, em que após a assunção do poder pelo Partido Comunista, a Corte Constitucional, expressivamente intrincada na definição de políticas nacionais, teve suas atividades suspensas por Boris Yeltsin em 1993 após adotar uma série de decisões contrárias à nova política que vinha sendo implementada. Apenas teve suas atividades retomadas em 1995, mas com grandes limitações quanto à competência que anteriormente detinha (p. 102).
} 
em suma, a importância de se analisar, no âmbito democrático, quais seriam as possíveis alternativas dos demais Poderes para buscar superar alguma decisão do Judiciário ou então de estabelecer limitações à sua influência na definição de políticas legislativas.

\subsubsection{A definição de políticas legislativas pelo Judiciário: experiências estrangeiras}

Os exemplos abaixo apontados permitem constatar que a expansão da influência política das Cortes Constitucionais representa um fenômeno que se faz sentir nos mais diversos Estados.

No contexto político-legislativo de Israel, Ran Hirschl relata que os ortodoxos compõem o único grupo religioso reconhecido oficialmente pelo Estado, e que consequentemente exercem quase que o monopólio na definição de questões religiosas e na imposição de critérios (rígidos) para a definição de quem pode ser considerado judeu. Essa definição possui importância prática na medida em que aos judeus (de acordo com o critério oficial) aplica-se a "lei do retorno", pela qual se lhes permite o livre ingresso em Israel, uma série de benefícios e a mais ampla cidadania israelense. Nesse contexto, o autor relata que a Corte Constitucional participou de maneira crucial na definição de quem poderia ser reconhecido como judeu, em decisão histórica tomada no início de 2002 e na qual, contrariando a recusa da ala ortodoxa de reconhecer como judeu pessoas que tivessem passado por conversão não-ortodoxa (isto é, que não cumprisse o ritual ortodoxo), determinou que tais conversões, ocorridas em Israel ou no exterior, possuíam o condão de atribuir o status de judeu para todos os fins legais e religiosos. ${ }^{89}$

Na mesma esteira, a Suprema Corte canadense atuou em definiçõos de políticas linguísticas, ao determinar a inconstitucionalidade de legislação que impusesse a aplicação de somente uma das línguas oficiais, a exemplo de decisão que declarou a inconstitucionalidade de uma lei de Quebec que determinava que o ensino público na província seria feito somente em francês. Do mesmo modo, a Corte participou das discussões políticas que envolveram o referendo do ano de 1995 que discutia sobre a secessão de Quebec (em que uma apertada maioria decidiu pela não separação), especialmente em razão da consulta feita pelo governo federal à Corte relativamente à

\footnotetext{
${ }^{89}$ HIRSCHL, Ran. Towards juristocracy: the origins and consequences of the new constitutionalism, op. cit., pp. 172 e ss.
} 
constitucionalidade de eventual declaração unilateral de independência feita pela referida província (decidindo a Corte que eventual declaração nesse sentido afrontava a Constituição e a legislação internacional, razão pela qual uma votação majoritária naquele referendo não seria suficiente para legitimar a independência da província). ${ }^{90}$

No caso de ambas as Cortes acima mencionadas, Ran Hirschl aponta que em verdade a judicialização da política nos respectivos Estados atingiu tamanha proporção que o Judiciário é instado a resolver questões de suma importância à própria identidade cultural e social da nação. Os casos exemplificados, bem como o papel que as Cortes vêm desempenhando e a forma pela qual lidam com questões políticas, permitem que o autor conclua pela verdadeira primazia dos Tribunais Constitucionais na definição de macropolíticas estatais.

Na Alemanha, por sua vez, o Tribunal Constitucional pronunciou-se pela inconstitucionalidade da quinta Lei para a Reforma do Direito Penal na parte que permitia o aborto desmotivado. ${ }^{91}$ Entendeu, naquela oportunidade, que o Estado faltava com seu dever de proteção da vida humana, i.e., da vida intrauterina, que encerra um ser humano independente da gestante e sujeito de proteção constitucional própria. Ressalte-se a ponderação daquele Tribunal de que a forma pela qual o Estado promove a proteção aos direitos previstos (no caso, ao direito à vida do nascituro) é de livre escolha do legislador. Entendeu-se, entretanto, que a reforma penal pretendida representaria uma desincumbência ampla e irrestrita da obrigação de garantir proteção. Interessante apontar que referida decisão motivou o surgimento de nova legislação, o que mostra que a interpretação fixada pelo Judiciário acaba por dar uma diretriz ao legislador. Tem-se aqui uma hipótese em que a Corte Constitucional entendeu pela possibilidade da medida pretendida, mas não na forma apresentada. A nova legislação, muito embora não mais tratasse de abortamento desmotivado, permitia a interrupção da gravidez em certos casos excepcionais. Ante a impugnação de dispositivos da lei que regulamentou novamente a matéria, o Tribunal alemão pronunciou-se novamente para definir que a prática abortiva poderia ser permitida legalmente em hipóteses acobertadas por estado de necessidade. ${ }^{92}$

\footnotetext{
${ }^{90}$ Idem, ibidem, loc. cit.

${ }^{91}$ MARTINS, Leonardo (org.). Cinqüenta anos de jurisprudência do Tribunal Constitucional Federal Alemão. Trad. Beatriz Henning et al. Montevideo: Konrad Adenauer Stiftung, 2005, pp. 265-273.

92 Idem, ibidem, pp. 273-293. Ainda sobre o Tribunal Constitucional alemão, destaca Oscar Vilhena Vieira: "O Tribunal esteve envolvido na tomada de decisões da maior parte das questões políticas relevantes para a consolidação da democracia e do estado de direito (...) tornando-se assim uma nova arena onde se desenrola a luta política, estritamente submetida, entretanto, aos valores estabelecidos na Constituição. Decidiu questões
} 
Na França, mesmo antes da Loi Constitutionnel du 23 juillet 2008, que institui uma forma de controle repressivo de constitucionalidade, o Conselho Constitucional já desempenhava papel relevante na política legislativa nacional, ainda que em sede preventiva de controle. Aponta Alec Stone Sweet ${ }^{93}$ que a Corte Constitucional evoluiu, ao longo das últimas décadas, em uma espécie de "corpo legislativo adjunto" com competência para vetar, emendar e até mesmo propor disposições normativas. Em casos sensíveis, (i) vetou em 1982 um projeto da esquerda voltado à nacionalização de empresas, entendendo que a legislação não resguardava adequadamente o direito à compensação pecuniária pela expropriação; ${ }^{94}$ (ii) em 1986, vetou a tentativa da direita em desregular a imprensa e a midia televisionada ${ }^{95}$ (iii) em 1993, impediu o prosseguimento de projeto da direita voltada à restrição da imigração e à expansão da discricionariedade administrativa em expulsar pessoas que requisitassem asilo político. ${ }^{96}$

Em caso mais recente ${ }^{97}$, o Conselho Constitucional foi chamado ao controle de constitucionalidade de legislação que buscava proibir a utilização, em locais públicos, de vestimentas que cobrissem todo o rosto do indivíduo. O caso assumiu relevância em razão da utilização da burqa por mulheres muçulmanas, que pela lei não mais poderiam vesti-las em locais públicos. A Corte entendeu pela constitucionalidade da lei, referendando, portanto, a proibição da utilização de burqa, afirmando que a legislação buscava assegurar a ordem pública bem como ponderava que a utilização, por mulheres, de vestimentas que escondessem o rosto as colocava em situação de inferioridade incompatível com os direitos constitucionais à igualdade e à liberdade. Ressaltou, expressamente, que a ponderação feita pelo legislador entre os princípios e direitos envolvidos não se mostrava desproporcional, mesmo porque restava resguardada o direito de utilização das vestimentas em espaços religiosos.

\footnotetext{
importantes a respeito de temas como armamento nuclear (1958); declaração de inconstitucionalidade de partidos políticos com objetivos incompatíveis aos princípios democráticos e aos direitos fundamentais, afastando dessa maneira ameaças provindas do próprio sistema partidário (1952 e 1956); diversas decisões no sentido de definir de maneira ampla o significado dos direitos fundamentais, ampla liberdade de expressão e de imprensa, associação e religião; (...) De qualquer modo o Tribunal de Karlsruhe, passou a ocupar um papel de primeiro plano dentre as institucionais governamentais alemãs, enquanto órgão encarregado de preservar os direitos fundamentais, de controlar o abuso do poder, de mediar o conflito entre os demais poderes assim como entre os componentes da federação." VIEIRA, Oscar Vilhena. Supremo Tribunal Federal: jurisprudência política. São Paulo: Editora Revista dos Tribunais, 1994, pp. 54-55. No mesmo sentido, ver: FAVOREU, Louis. As Cortes Constitucionais. São Paulo: Landy Editora, 2004, pp. 73 e ss.

${ }^{93}$ STONE SWEET, Alec. "Judicialization and the construction of governance", in: SHAPIRO, Martin; STONE SWEET, Alec, op. cit., p. 82.

${ }^{94}$ Decisão n. 81-132 DC de 16 de janeiro de 1982.

${ }^{95}$ Decisão n. 86-210 DC de 29 de julho de 1986.

${ }^{96}$ Decisão n. 93-325 DC de 13 de agosto de 1993.

${ }^{97}$ Decisão n. 2010-613 DC de 7 de outubro 2010.
} 
Nessa mesma esteira, Louis Favoreu aponta a importância do Conselho Constitucional francês na definição de matérias relativas à vida política nacional, em especial no tocante à definição e proteção de liberdades e direitos fundamentais. ${ }^{98}$

Referido autor também destaca a relevância da Corte Constitucional italiana na definição de matérias de alta relevância política, em especial no tocante a temas relativos a direitos fundamentais. Ressalta que a Corte atuou de forma decisiva ao neutralizar os efeitos antidemocráticos da legislação fascista - anterior, portanto, à Constituição de 1947 - que não foi objeto de revogação, ou mesmo ao readequar seus termos mediante emprego de sentenças aditivas ou substitutivas. ${ }^{99}$ Da mesma forma, aponta que o Tribunal atuou de maneira decisiva ao definir o grau de proteção dos diversos direitos fundamentais, chegando a reconhecer que certos direitos sociais constitucionalizados eram, inclusive, passíveis de aplicação direta. ${ }^{100}$ Conclui, assim, que a Corte desenvolve uma atividade insubstituível ao contornar omissões legislativas, razão pela qual é vista como um "colegislador", especialmente em virtude de suas decisões com efeitos aditivos ou substitutivos. ${ }^{101}$

Por fim, deve-se ainda mencionar a atuação da Suprema Corte estadunidense. Muito embora sua atuação política, nos dias de hoje, seja menos sensível que no período do New Deal e no que sucedeu a este ${ }^{102}$, é incontestável que aquele Tribunal teve participação decisiva no tocante à definição de questões políticas nos Estados Unidos, seja pela paradigmática decisão no caso Marbury v. Madison, que em verdade institucionalizou o sistema americano de controle de constitucionalidade, seja no combate à intervenção estatal no período posterior à crise de 1929, conforme já destacado, seja já na segunda metade do século XX (em especial durante a Warren Court ${ }^{103}$ ), em que atuou de maneira decisiva na expansão dos direitos fundamentais.

A esse respeito, destaca Martin Shapiro que expansão do poder político do Judiciário nos Estados Unidos está essencialmente ligado ao movimento de proteção a direitos fundamentais, citando como paradigmático nesse processo a decisão no caso

\footnotetext{
${ }^{98}$ FAVOREU, Louis, op. cit., pp. 99 e ss.

${ }^{99}$ Idem, ibidem, p. 88.

${ }^{100}$ Idem, ibidem, p. 89.

${ }^{101}$ Idem, ibidem, p. 91.

102 TUSHNET, Mark. The new constitutional order, op. cit., pp. 33-95. O autor retrata o declínio do papel da Suprema Corte na definição de políticas fundamentais nos dias atuais, em contraposição ao papel de destaque que desempenhou na segunda metade do século XX.

${ }^{103}$ SHAPIRO, Martin. "Judicialization of politics in the United States", op. cit., p. 104.
} 
Brown v. Board of Education ${ }^{104}$, em que a Corte impôs uma nova política, voltada ao combate à política de segregação racial em escolas públicas, que os demais Poderes recusavam-se a implementar. ${ }^{105}$ Pondera Oscar Vilhena Vieira que essa decisão, ao por fim à ideia de separate but equal - em que se sustentava a política segregacionista -, representa uma mudança no paradigma de atuação da Corte no sentido de apenas bloquear atos inconstitucionais, voltando-se então a uma participação mais afirmativa na proteção de direitos fundamentais. Tanto assim que, ante a resistência encontrada na efetivação da decisão, a Suprema Corte determinou, no ano seguinte ao do julgamento do caso, que as escolhas públicas implementassem a decisão com celeridade, atribuindo aos juízes federais a competência e a incumbência de fiscalizar a efetivação do novo sistema de ensino no país. ${ }^{106}$

Nesse mesmo sentido, Martin Shapiro conclui que a Corte passa a ser vista como um espaço alternativo de debate político, bem como que ela passa a atuar de forma a corrigir falhas ou patologias do processo democrático, extraindo a legitimidade de sua atuação da ideia de proteção de minorias e na premissa de que em certos casos a democracia depende de intervenção judicial para garantir sua retidão. ${ }^{107} \mathrm{O}$ autor ainda enfatiza a expansão do Judiciário no controle dos atos da administração pública, em especial ao longo das décadas de 60, 70 e 80, quando então as cortes estadunidense desempenharam um papel primordial na definição e no controle de políticas de saúde, segurança e de meio ambiente, remodelando as regras do jogo regulatório. ${ }^{108}$

Outras foram as decisões emblemáticas da Suprema Corte estadunidense, algumas já mencionadas, no tocante à definição e à proteção de direitos fundamentais, a exemplo da decisão que reconhecia o direito de uso de contraceptivos (Griswold v. Connecticut ${ }^{109}$ ), bem como aquela que tutelava a liberdade de optar pelo abortamento (Roe v. Wade ${ }^{110}$ ). Resta evidente a inclinação do Judiciário em atuar na delimitação do conteúdo e na extensão dos direitos constitucionalizados, na medida em que muito mais que apenas invalidar as normas impugnadas, desenvolvia uma ratio decidendi mais ampla que em verdade estabelecia uma nova política legislativa de eficácia ampla e generalizada. Cristina

\footnotetext{
${ }^{104}$ Caso 347 U.S. 483 (1954).

105 Idem, ibidem, pp. 103-104.

${ }^{106}$ VIEIRA, Oscar Vilhena. Supremo Tribunal Federal: jurisprudência política, op. cit., pp. 64-66.

${ }^{107}$ SHAPIRO, Martin. "Judicialization of politics in the United States", op. cit., p. 104.

${ }^{108}$ Idem, ibidem, pp. 106 e ss.

${ }^{109}$ Caso 381 U.S. 479 (1965).

${ }^{110}$ Caso 410 U.S. 113 (1973).
} 
Queiroz apresenta precisa ponderação a respeito da importância desses dois casos à mudança do padrão de atuação da Suprema Corte:

[E]m Griswold v. Connecticut, o Tribunal Supremo reconhece, pela primeira vez, com força constitucional, o "direito à privacidade" (...) para além de seus aspectos negativos de protecção do domicílio ou da integridade física pessoais. Este reconhecimento aberto dos valores de "autonomia pessoal" na jurisprudência da Supreme Court, foi obra do Tribunal Burger. A partir de 1973, com Roe v. Wade, a decisão que despenalizou a interrupção voluntária da gravidez em determinados casos, a utilização do substantive due process foi-se progressivamente ampliando, estendendo-se, na prática, à quase totalidade das cláusulas constitucionais, abandonando o campo limitado dos "direitos económicos e sociais" para abarcar o círculo dos direitos de "autonomia", "privacidade", "intimidade", "personalidade" e "liberdade" pessoais"111

${ }^{111}$ QUEIROZ, Cristina, op. cit., pp. 254-255. 


\section{O SUPREMO TRIBUNAL FEDERAL NA ARENA POLÍTICA}

\subsection{A Constituição de 1988 e a expansão da influência política do Supremo Tribunal Federal}

A Constituição de 1988 trouxe grandes inovações no tocante ao nosso sistema de controle de constitucionalidade, o que por sua vez, em conjunto com a positivação de amplo rol de direitos e garantias constitucionais, abriu espaço para que o Judiciário, e o Supremo Tribunal Federal em especial, passasse a atuar de maneira incisiva na definição de questões políticas de relevância nacional. O enfoque do presente capítulo recai sobre a atuação do próprio Supremo Tribunal Federal em razão da maior abrangência e relevância de suas decisões, buscando-se demonstrar que este se tornou verdadeiro copartícipe na construção das regras e princípios do nosso ordenamento jurídico.

2.1.1 Alguns apontamentos sobre a dimensão política do sistema de controle de constitucionalidade brasileiro

O novo marco constitucional brasileiro de 1988 trouxe importantes alterações para o sistema de controle de constitucionalidade pátrio. Cumpre destacar que a matriz do sistema brasileiro, desde o início da República, foi o sistema estadunidense de revisão judicial $^{112}$, inexistindo de início, portanto, institutos que permitissem o controle abstrato de normas, seara na qual o viés político da atuação judicial resta muito mais evidente - ao menos diante da realidade do sistema de civil law, em que, como regra, não há institucionalização do stare decisis.

Tal sistemática teve sua primeira mudança com o surgimento, sob a égide da Constituição de 1934, da denominada ação direta interventiva declaratória de inconstitucionalidade ${ }^{113}$, que, a despeito de suas peculiaridades, ${ }^{114}$ encerrava, de alguma forma, um juízo abstrato da adequação constitucional do ato impugnado.

\footnotetext{
${ }^{112}$ VIEIRA, Oscar Vilhena. Supremo Tribunal Federal: jurisprudência política, op. cit., pp. 73-74; RAMOS, Elival da Silva. Controle de constitucionalidade no Brasil: perspectivas de evolução, op. cit., 183 e ss.

${ }^{113}$ RAMOS, Elival da Silva. Controle de constitucionalidade no Brasil: perspectivas de evolução, op. cit., pp. 196-197.
} 
O controle abstrato apenas surgiu, como instituto autônomo e voltado a extirpar do ordenamento norma que contrariasse os parâmetros constitucionais, durante a vigência da Constituição de 1946, por intermédio da Emenda Constitucional no 16 de 1965, que inseriu no sistema brasileiro a ação direta de inconstitucionalidade, processada diretamente junto ao Supremo Tribunal Federal mediante provocação do Procurador Geral da República. A despeito da relevância desse movimento no sentido da ampliação do controle normativo jurisdicional, em especial no tocante à proteção das garantias individuais, há que se ter em mente, conforme ensina Oscar Vilhena Vieira, que a ação direta de inconstitucionalidade surge no contexto da ditadura militar, em um período de instabilidade institucional deflagrada pela supressão de garantias do Judiciário, e no qual o próprio Governo ampliou o número de membros do Supremo Tribunal Federal para garantir a nomeação de uma maioria no órgão. Mais que isso, tem-se ainda que o fato de o Procurador-Geral da República ter a competência exclusiva para lançar mão dessa via de controle, bem como a peculiaridade de que, à época, o ocupante do cargo poderia ser exonerado ad nutum pelo Presidente da República, razões pelas quais o instituto mostrouse menos relevante no contexto do controle normativo do que inicialmente se poderia esperar. $^{115}$

A Constituição de 1967 não trouxe mudanças significativas ao sistema de controle de constitucionalidade, podendo-se destacar, por exemplo, a ampliação do escopo da representação para intervenção federal e mesmo a criação da representação de inconstitucionalidade voltada a interpretação de ato normativo federal ou estadual, instrumento também de competência exclusiva do Procurador-Geral da República junto ao Supremo Tribunal Federal. ${ }^{116}$

Foi a Constituição de 1988 que efetivamente expandiu a competência de fiscalização normativa do Supremo Tribunal Federal, abrindo espaço para que este passasse, paulatinamente e com maior relevância, a integrar o contexto político da

\footnotetext{
${ }^{114}$ Elival da Silva Ramos entende que esse instituto não encerra, verdadeiramente, nem controle abstrato nem controle concreto de constitucionalidade: "Não existe, ousamos afirmar, nem controle principal nem tampouco incidental de inconstitucionalidade que seja provocado por meio de 'ação direta de inconstitucionalidade interventiva', pela singela razão de que a atividade do Supremo Tribunal Federal, na espécie, não é de natureza jurisdicional. (...) A peculiaridade, no caso, é que uma das etapas do procedimento de intervenção normativa, no plano federal, consiste na avaliação, por critério rigorosamente jurídico, pela Suprema Corte da constitucionalidade da lei ou ato normativo estadual apontado pelo Procurador-Geral da República como violador de princípio sensível, somente sendo editado o decreto de intervenção se houver declaração de inconstitucionalidade." Idem, ibidem, pp. 423-424.

${ }^{115}$ VIEIRA, Oscar Vilhena. Supremo Tribunal Federal: jurisprudência política, op. cit., pp. 77-79.

${ }^{116}$ MENDES, Gilmar Ferreira. Direitos fundamentais e controle de constitucionalidade, op. cit., pp. 253254.
} 
definição de políticas nacionais. O controle concreto permaneceu em nosso sistema. $\mathrm{O}$ controle abstrato, por sua vez, passa por expressiva ampliação. E isso tanto no que diz respeito aos instrumentos de controle, quanto aos parâmetros normativos de constitucionalidade.

Muito embora o Supremo Tribunal Federal não tenha sido alçado à posição de verdadeira Corte Constitucional, passou a mais fortemente desempenhar funções específicas de órgãos dessa natureza.

De início, tem-se a própria reestruturação da ação direta de inconstitucionalidade, instrumento do controle abstrato por excelência, que contou com a ampliação da competência de sua propositura, que deixou de ser exclusiva do Procurador-Geral da República, integrando também o âmbito de competências do Presidente da República, das Mesas do Senado Federal e da Câmara dos Deputados, da Mesa das Assembleias Legislativas ou da Câmara Legislativa do Distrito Federal, dos Governadores de Estado ou do Distrito Federal, do Conselho Federal da Ordem dos Advogados do Brasil, de partidos políticos com representação no Congresso Nacional e de confederações sindicais ou entidades de classes de âmbito nacional. ${ }^{117}$ Para além da ampliação das vias de acesso ao controle abstrato, a reafirmação das garantias institucionais dos membros do Judiciário e do Ministério Público deram novas perspectivas para a sedimentação da importância da ação direta no controle normativo. Conforme conclui Gilmar Ferreira Mendes, essa ampliação acaba por restringir a relevância do controle concreto de constitucionalidade, “permitindo que, praticamente, todas as controvérsias constitucionais relevantes sejam submetidas ao Supremo Tribunal Federal mediante processo de controle abstrato de normas.",118

Foram igualmente estipulados novos instrumentos de controle normativo abstrato, que se somaram à ação direta de inconstitucionalidade. Nesse sentido, tem-se (i) a ação de descumprimento de preceito fundamental, que veio a suprir uma barreira teórica à admissão da ação direta de inconstitucionalidade contra atos normativos anteriores à Constituição vigente (dado que, no plano normativo-teórico, tem-se aí não uma questão de inconstitucionalidade propriamente dita, mas de não-recepção do ato normativo pretérito), bem como a viabilizar o questionamento de leis municipais frente à Constituição Federal

\footnotetext{
${ }^{117}$ Artigo 103 da Constituição Federal de 1988.

${ }^{118}$ MENDES, Gilmar Ferreira. Direitos fundamentais e controle de constitucionalidade, op. cit., p. 256. Em sentido contrario, ver: RAMOS, Elival da Silva. Controle de constitucionalidade no Brasil: perspectivas de evolução, op. cit., pp. 232-233.
} 
diretamente no Supremo Tribunal Federal; (ii) os instrumentos para controle de omissão legislativa, a exemplo da ação direta de inconstitucionalidade por omissão, que em verdade apenas se distingue da ação direta de inconstitucionalidade em razão do objeto de impugnação ${ }^{119}$ e o mandado de injunção ${ }^{120}$, cujos contornos e implicações, apesar de oscilantes na jurisprudência do Supremo Tribunal Federal, tem adotado feições que atribuem à cúpula do Judiciário verdadeiros poderes legiferantes ${ }^{121}$; e (iii) a ação declaratória de constitucionalidade de lei ou ato normativo federal (cf. artigo 102, I, a, da Constituição Federal de 1988), instituída pela Emenda Constitucional n. 3, de 1993 - cujo rol de legitimados à sua propositura, inicialmente mais restrito, foi igualado àquele relativo à ação direta de inconstitucionalidade por força da Emenda Constitucional n. 45, de 2004 , e que visa a propiciar a uniformização do entendimento a respeito da constitucionalidade de ato normativo ${ }^{122}$, dado o efeito vinculante e erga omnes em decisões proferidas nessa seara (cf. artigo 102, §2 da Constituição Federal de 1988).

A esses instrumentos juntou-se, com o advento da Emenda Constitucional $n^{\circ} 45$, de 2004, a figura da súmula vinculante. Conquanto esta não se insira no âmbito do controle abstrato de constitucionalidade, visa à uniformização da jurisprudência e, na prática, pode servir de mecanismo para que o Supremo Tribunal Federal objetive efeitos de decisões proferidas em sede concreta de controle de constitucionalidade, que, como é cediço, produz efeitos apenas às partes ligadas pelo litígio subjetivo que acaba por chegar à Corte. Esse instrumento atribui ao Supremo Tribunal Federal a competência de editar atos que se

\footnotetext{
119 "[S]ob a ótica da disciplina normativa, não existe uma ação direta de inconstitucionalidade por omissão distinta da ação direta por inconstitucionalidade comissiva. Na verdade, admite a Constituição brasileira que a ação direta de inconstitucionalidade possa ser proposta tendo em vista a omissão de medida a tornar efetiva norma constitucional (art. 103, $\S 2^{\circ}$ ). Portanto, a denominada ação direta por inconstitucionalidade por omissão nada mais significa do que um modo especial de exercício da ação direta de inconstitucionalidade tout court." RAMOS, Elival da Silva. Controle de constitucionalidade no Brasil: perspectivas de evolução, op. cit., p. 305.

${ }^{120}$ Instituto que, cf. artigo $5^{\circ}$, LXXI, da Constituição Federal de 1988, tem cabimento "sempre que a falta de norma regulamentadora torne inviável o exercício dos direitos e liberdades constitucionais e das prerrogativas inerentes à nacionalidade, à soberania e à cidadania."

${ }^{121}$ A respeito dessas oscilações no tocante aos limites e aos efeitos do mandado de injunção, que já foi compreendido como um instituto com efeitos práticos semelhantes aos da ação direta de inconstitucionalidade por omissão (no sentido de resultar em provimento meramente mandatório ao Legislativo ou ao Executivo para que supra a lacuna que inviabilize o gozo de um direito fundamental) e hoje se aproxima de um instrumento que permite uma normatização precária por parte do Judiciário, ver: RAMOS, Elival da Silva. Controle de constitucionalidade no Brasil: perspectivas de evolução, op. cit., pp. 311 e ss.

122 “O seu objetivo é transferir para o Supremo a decisão sobre a constitucionalidade de um dispositivo legal que esteja sendo duramente atacado pelos juízes e tribunais inferiores, suspendendo assim o controle difuso da constitucionalidade, uma vez que declarada a constitucionalidade da norma, todos os juízes e também o Poder Executivo ficam obrigados à decisão proferida pelo Tribunal." VIEIRA, Oscar Vilhena. Supremo Tribunal Federal: jurisprudência política, op. cit., p. 89.
} 
revestem de normatividade de caráter geral e abstrato, cuja observância se torna obrigatória aos demais órgãos do Judiciário e à Administração Pública de todos os entes da Federação. ${ }^{123}$ Conquanto não se trate de atribuição de verdadeira função legiferante ${ }^{124}$, é intuitivo que, ao poder fixar entendimentos e interpretações quanto a dispositivos legais por intermédio de preceitos normativos, o Supremo Tribunal Federal pode largamente atuar na (re)definição de escolhas do legislador, com o que, muito mais que simplesmente invalidar uma norma inconstitucional, pode em verdade direcionar de maneira vinculante até mesmo para a Administração Pública - a aplicação da norma objeto de regulamentação pela Corte. $^{125}$

À exceção da súmula vinculante e da ação declaratória de constitucionalidade, criações do Poder Constituinte de reforma, os demais instrumentos mencionados inseriamse no âmbito do texto original da Constituição de 1988. Denota-se a tentativa de ampliação do escopo de atuação do Supremo Tribunal Federal no controle dos atos estatais e a abertura da política à ingerência judicial, mediante (i) positivação de mecanismos que propiciam decisões com efeitos mais abrangentes e vinculantes, com o que se viabiliza igualmente a maior participação da cúpula do Judiciário no campo político, (ii) reforço das garantias institucionais do Judiciário (e do Ministério Público, o que robustece a independência do Procurador-Geral da República no controle de inconstitucionalidades) e, (iii) ampliação do rol de legitimados a provocar o controle abstrato de normas, o que por sua vez expande as vias de acesso e, naturalmente, aumenta as chances de o Supremo Tribunal Federal vir a ser instado a se pronunciar sempre que uma questão de relevância entrar em discussão na agenda política nacional.

\footnotetext{
${ }^{123}$ Cf. artigo 103-A da Constituição Federal de 1988: "O Supremo Tribunal Federal poderá, de ofício ou por provocação, mediante decisão de dois terços dos seus membros, após reiteradas decisões sobre matéria constitucional, aprovar súmula que, a partir de sua publicação na imprensa oficial, terá efeito vinculante em relação aos demais órgãos do Poder Judiciário e à administração pública direta e indireta, nas esferas federal, estadual e municipal, bem como proceder à sua revisão ou cancelamento, na forma estabelecida em lei."

124 “A orientação jurisprudencial sumulada consubstancia normas gerais e abstratas, endereçadas aos órgãos administrativos ou judiciários, incumbidos da aplicação oficial do direito pátrio, na forma de comandos para que, em face da Constituição, interpretem lei ou dispositivo legal (ou constitucional) de determinado modo ou adotem determinada postura quanto à validade ou eficácia de lei ou dispositivo legal. Essa normatividade sumular, todavia, não está situada no nível primário da hierarquia própria de nosso ordenamento, vale dizer, ao lado daquela resultante de leis complementares ou ordinárias ou de regulamentos autônomos. Em outras palavras, ao expedir súmulas vinculantes não está o Supremo Tribunal Federal, em sentido precisando, legislando. Cuida-se, a nosso ver, de uma atividade de produção normativa com características próprias." RAMOS, Elival da Silva. Controle de constitucionalidade no Brasil: perspectivas de evolução, op. cit., p. 376.

${ }^{125}$ A esse respeito, e apontando extensão dos efeitos do instituto, defende Roger Stiefelmann Leal que a vinculação, em caso de súmulas vinculantes, deve se dar não apenas quanto ao dispositivo de seu enunciado, mas igualmente à ratio decidendi que dos julgamentos que embasaram sua edição. LEAL, Roger Stiefelmann. O efeito vinculante na jurisdição constitucional. São Paulo: Saraiva, 2006, pp. 174-176.
} 
Some-se a isso a ampliação dos próprios parâmetros constitucionais de controle, o que por sua vez resulta em maiores possibilidades de controle e de intervenção judicial em virtude da gama de ponderações e valorações que podem ser arguidas na tentativa de invalidar algum ato normativo. Quanto a isto, pode-se citar tanto a ampliação do rol de direitos e garantias fundamentais (inclusive mediante previsão de direitos de cunho social e econômico) quanto o estreitamento da rigidez constitucional, até mesmo contra o Poder Constituinte derivado, em virtude da ampliação das cláusulas pétreas, que passaram a integrar os direitos e as garantias fundamentais. ${ }^{126}$

Contribuiu certamente para esse processo o contexto político nacional do período anterior à Constituição de 1988, que por sua vez representou um passo em direção à democratização e à superação do regime ditatorial. Cabe aqui aludir ao quanto já afirmado no sentido de que a ruptura com regimes antidemocráticos tende a propiciar um impulso voltado à institucionalização de mais instrumentos de controle da atividade estatal, bem como ao reforço dos já existentes. Ademais, as incertezas quanto ao desenvolvimento da nova realidade político-eleitoral - em especial pela reinserção das eleições diretas para Presidência da República em nosso sistema -, bem como a experiência pouco expressiva do controle de constitucionalidade abstrato durante o regime ditatorial, em razão da concentração da competência de provocação do controle na figura Procurador-Geral da República (demissível ad nutum pelo Presidente da República), podem explicar a ampliação das vias de acesso à contestação de políticas legislativas junto à cúpula do Poder Judiciário, sempre como forma de seguro político a partidos e grupos minoritários.

Os instrumentos surgidos após a promulgação da Constituição de 1988, a exemplo da ação declaratória de constitucionalidade e da súmula vinculante, embora tenham sido criados provavelmente com base em outros propósitos políticos, dada a paulatina consolidação do regime democrático brasileiro, claramente atribuem maiores poderes

\footnotetext{
126 “A maior novidade desse artigo [60, §4, da Constituição Federal de 1988] está na inclusão entre as limitações materiais ao poder de reforma da Constituição, dos direitos inerentes ao exercício da democracia representativa e aos direitos e garantias individuais. A dimensão dessa limitação alarga-se ao ser interpretada em conjunto com o $\S 2 .^{\circ}$, do art. 5. ${ }^{\circ}$, que prevê 'que os direitos e garantias expressos nesta Constituição não excluem outros decorrentes do regime e dos princípios por ela adotados, ou dos tratados internacionais em que a República Federativa do Brasil seja parte'. (...) Abriu-se, por intermédio desses dispositivos, associados com a competência do Supremo Tribunal Federal para apreciação da constitucionalidade das leis (...) uma enorme porta para que o Supremo Tribunal Federal exerça a função de guardião dos direitos fundamentais." VIEIRA, Oscar Vilhena. Supremo Tribunal Federal: jurisprudência política, op. cit., pp. 91-92. No tocante às cláusulas pétreas, o mesmo autor defende a institucionalização de normas dotadas de superconstitucionalidade, que gozam de posição privilegiada em relação às demais normas constitucionais. VIEIRA, Oscar Vilhena. A Constituição e sua reserva de Justiça (um ensaio sobre os limites materiais do poder de reforma), op. cit., pp. 1343 ss.
} 
decisórios ao Supremo Tribunal Federal, ainda que seja a pretexto de permitir uma uniformização jurisprudencial e de evitar a proliferação desnecessária de demandas repetidas.

Essa profusão e evolução de institutos, conforme já afirmado, abriram espaço para a maior ingerência do Supremo Tribunal Federal no campo político, porque lhe permitem atuar tanto no controle normativo quanto na fixação de interpretações e aplicações de dispositivos legais, mediante decisões de efeitos abrangentes e vinculantes. A judicialização de questões políticas acaba sendo um consectário natural, na medida em que, dada a profusão de enunciados que balizam a atividade estatal e o amplo rol de direitos e garantias fundamentais, permite o confronto de praticamente toda e qualquer política legislativa implementada. A maior ou menor participação política do Supremo Tribunal Federal, assim como já ponderado, perpassa, em verdade, pela forma como a Corte encara seu papel junto à sociedade e às demais instituições estatais, havendo forte ligação, portanto, com a própria política institucional da Corte ao longo do tempo.

2.1.2 Os mecanismos de intervenção do Supremo Tribunal Federal na definição de políticas nacionais

Foram já mencionados os instrumentos de controle de constitucionalidade previstos na Constituição e que permitem, em maior ou menor escala, a participação do Supremo Tribunal Federal na política nacional. No presente capítulo, buscar-se-á apontar as nuances existentes entre esses mecanismos, menos quanto à natureza e ao rito de processamento da respectiva ação de controle, e mais quanto às possibilidades de intervenção política que conferem à Corte.

A ação direta de inconstitucionalidade é o mecanismo por excelência do controle abstrato de constitucionalidade no direito pátrio. Seu objetivo é o de obter do Supremo Tribunal Federal um pronunciamento que reconheça a inadequação entre a norma impugnada e certos parâmetros constitucionais apontados como violados. Conforme já se afirmou, tem-se aí uma atuação que, de certa maneira, equipara-se à função de um legislador negativo, dado que a Corte possui competência para determinar, de forma vinculativa e com efeitos erga omnes, que a norma inconstitucional seja extirpada do ordenamento. É intuitiva a constatação de que essa competência possui grande relevância 
quanto à possibilidade de intervenção do Supremo Tribunal Federal em questões políticas: considerando a profusão de enunciados em nosso sistema constitucional, muitas são as matérias que, em tese, podem ter sua constitucionalidade discutida por meio de ação direta de inconstitucionalidade. Com isso abre-se a possibilidade de o Supremo Tribunal Federal participar da (re)discussão de uma infinidade de políticas nacionais, reapreciando os juízos de conveniência e oportunidade bem como as ponderações principiológicas - mormente do Legislativo - que pautaram a produção normativa impugnada.

O mesmo se diga quanto à arguição de descumprimento de preceito fundamental. Muito embora esta tenha hipóteses de cabimento distintas daquelas relativas à ação direta de inconstitucionalidade - sendo, em verdade, uma ação de cabimento subsidiário ${ }^{127}$-, ambas visam a, na prática, instar o Supremo Tribunal Federal a reconhecer uma inadequação normativa frente à Constituição Federal. Também aqui, portanto, tem-se uma atividade que permite uma revaloração jurídica da decisão política que resultou na norma impugnada.

A afirmação de que tais instrumentos alçam o Supremo Tribunal Federal a um novo patamar no contexto político soa óbvia, dado se tratar de uma consequência idiossincrática à função de controle. Afinal, se possui a competência de determinar a retirada de uma norma do ordenamento, total ou parcialmente, naturalmente reside aí algum elemento de influência política, uma vez que é pressuposto disso a realização de um juízo de constitucionalidade e de uma ponderação de valores que, por bem ou por mal, acabam por sobrepor-se aos equacionamentos feitos pelo próprio legislador. A questão, entretanto, parece assumir outra relevância ao se ter em conta a potencialidade desses institutos no sentido da ampliação do espaço de atuação do Supremo Tribunal Federal, o que por sua vez leva em conta, deve ser novamente reiterado, a política institucional da Corte e os mecanismos de que lança mão ao delimitar sua própria competência.

O desenvolvimento do controle de constitucionalidade jurisdicional repressivo atribuiu nuances aos institutos acima mencionados que dotam o Supremo Tribunal Federal de outros mecanismos que não apenas a simples e direta exclusão do texto normativo do ordenamento jurídico.

\footnotetext{
${ }^{127}$ Conforme artigo $4^{\circ}, \S 1^{\circ}$, da lei 9.882 , de 1999 , que estabelece o cabimento dessa ação quando não haja outro meio eficaz para sanar a lesividade arguida - o que equivale a dizer seu cabimento depende do não cabimento de outros instrumentos de controle abstrato de normas. Sobre as hipóteses de cabimento da ação de descumprimento de preceito fundamental, ver: DIMOULIS, Dimitri; LUNARDI, Soraya. Curso de processo constitucional: controle de constitucionalidade e remédios constitucionais. São Paulo: Atlas, 2011, pp. 172-174.
} 
Segundo Gilmar Ferreira Mendes, a doutrina constitucional brasileira incorporou uma máxima do direito estadunidense segundo o qual "deve o juiz, na dúvida, reconhecer a constitucionalidade da lei”. ${ }^{128}$ Fala-se, assim, no princípio da presunção da constitucionalidade. ${ }^{129}$ Com isso quer-se dizer que, havendo qualquer dúvida a respeito do sentido que se deve atribuir aos enunciados normativos, o julgador deve optar pela interpretação que compatibilize a norma com o texto constitucional, realizando o que se denomina de interpretação conforme a Constituição. Destaca Elival da Silva Ramos que a doutrina e a jurisprudência nacionais haviam importado essa técnica da doutrina estadunidense para o controle concreto de constitucionalidade, tendo-se estendido sua aplicação, pouco a pouco, ao controle abstrato. ${ }^{130}$ Pautado nesse postulado, portanto, o Supremo Tribunal Federal, ao ser instado a realizar controle de constitucionalidade, passou analisar, previamente, se a norma impugnada admite alguma interpretação que permita a permanência do texto normativo no ordenamento. Em caso positivo, pronuncia-se pela manutenção do enunciado, ainda que limitando seu âmbito de incidência de modo a extirpar aquelas interpretações que o tornariam contrários à Constituição.

A doutrina e a jurisprudência apontam um desdobramento dogmático entre as formas pelas quais o manejo desse preceito pode adotar quando transportado para a via abstrata de controle de constitucionalidade. Entende-se, grosso modo, que a interpretação conforme a Constituição é uma técnica de interpretação de que se deve valer todo e qualquer julgador. Ainda assim, no âmbito do controle concentrado de constitucionalidade, ao se deparar com a impugnação de uma norma, a Corte pode, ao lançar mão desse método exegético, entender que o texto normativo é válido desde que interpretado de certa maneira ou desde que excluídas algumas hipóteses de interpretação. Em tais casos, ao valer-se da interpretação conforme, a decisão do Tribunal pode assemelhar-se, na prática, ao que se

\footnotetext{
${ }^{128}$ MENDES, Gilmar Ferreira. Jurisdição constitucional: o controle abstrato de normas no Brasil e na Alemanha. $5^{a}$ edição. São Paulo: Saraiva, 2005, p. 346

129 "A lei, porém, dado o seu caráter obrigatório, é válida até que o Poder Judiciário a declare incompatível com a Constituição. Não se trata de conjectura, probabilidade ou suposição: a obrigatoriedade existe. O que se quer dizer, ao enunciar o princípio, é que as leis não têm a sua eficácia dependente de prévia autorização do Poder Judiciário. Não se subordinam à sanção deste para que se possam aplicar aos fatos emergentes. Tornam-se definitivas e compulsórias antes mesmo que o Judiciário as julgue e confirme.” BITTENCOURT, Carlos Alberto Lúcio. O controle jurisdicional da constitucionalidade das leis. Rio de Janeiro: Forense, 1968, p. 114.

${ }^{130}$ RAMOS, Elival da Silva. Controle de constitucionalidade no Brasil: perspectivas de evolução, op. cit., p. 266.
} 
denomina de declaração de nulidade parcial sem redução de texto, que por sua vez é uma técnica decisória, um método de exercício do controle de constitucionalidade. ${ }^{131}$

Discute-se a respeito da diferenciação entre os institutos. Nesse sentido, por exemplo, Elival da Silva Ramos afirma que "as decisões de controle que se limitam a fazer o uso da interpretação conforme configuram, na verdade, decisões de improcedência total das ações diretas de inconstitucionalidade" ${ }^{132}$, dado que o Tribunal, no dispositivo da decisão, reconhece que o ato normativo é constitucional se interpretado de determinada forma; em decisões que declaram nulidade parcial sem redução de texto, por outro lado, o dispositivo da decisão encerra expressa exclusão de variantes interpretativas do texto normativo, razão pela qual, conclui o autor, "é estreme de dúvidas de que se está diante de um julgamento no sentido da procedência parcial da ação direta" ${ }^{\prime 33}$. O próprio autor, entretanto, reconhece que a distinção é tênue, dado que a interpretação conforme, mesmo que implicitamente, impõe o reconhecimento de alguma inconstitucionalidade normativa relativamente às demais interpretações que acabam por ser excluídas, também de forma tácita. $^{134}$

Conquanto a diferenciação seja delicada ${ }^{135}$, parece correto afirmar que, tanto em um quanto em outro caso, o texto normativo é mantido, mas o Tribunal acaba por limitar o

\footnotetext{
${ }^{131}$ Nesse sentido, por exemplo, afirmou o Ministro Moreira Alves na representação n. 1.417-7/DF (relator Ministro Moreira Alves, j. em 09.12.1987), que é o leading case da Corte a respeito dos limites da interpretação conforme à Constituição: "O princípio da interpretação conforme à Constituição é, na verdade, um princípio que se situa no âmbito do controle da constitucionalidade, e não apenas uma simples regra de interpretação." (fl. 33 do voto) (realces originais)

${ }^{132}$ RAMOS, Elival da Silva. Controle de constitucionalidade no Brasil: perspectivas de evolução, op. cit., p. 267.

${ }^{133}$ Idem, ibidem, p. 269.

${ }^{134}$ Idem,ibidem, p. 266. Do mesmo modo, ponderou o Ministro Moreira Alves na representação n. 1.4177/DF (relator Ministro Moreira Alves, j. em 09.12.1987): "O mesmo ocorre [i.e., uma declaração de inconstitucionalidade] quando Corte dessa natureza, aplicando a interpretação conforme à Constituição, declara constitucional uma lei com a interpretação que a compatibiliza com a Carta Magna, pois, nessa hipótese, há uma modalidade de inconstitucionalidade parcial (a inconstitucionalidade parcial sem redução do texto (...), o que implica dizer que o Tribunal Constitucional elimina - e atua, portanto, como legislador negativo - as interpretações por ela admitidas, mas inconciliáveis com a Constituição." (fl. 38 do voto) (realces originais).

${ }^{135}$ Ainda sobre a distinção sobre a interpretação conforme e a declaração de nulidade parcial sem redução de texto: "A diferença não está na natureza constitucional ou inconstitucional do dispositivo e a declaração de constitucionalidade não é logicamente necessária na interpretação conforme. Vimos que o STF declara a inconstitucionalidade parcial da norma, mesmo na interpretação conforme. Isso não está equivocado, pois na interpretação conforme ocorre inconstitucionalidade, sendo inconstitucionais interpretações que se encontram dentro da moldura do dispositivo impugnado. (...) A diferença entre a interpretação conforme e a declaração de inconstitucionalidade parcial sem redução de texto está no critério utilizado para fiscalizar a constitucionalidade. No primeiro caso, o problema diz respeito à interpretação da norma; no segundo, o problema diz respeito aos casos reais em que sua aplicação é permitida. Mais especificamente, na interpretação conforme se avalia o dispositivo, censurando certas 'possibilidades de interpretação' que o legislador autorizou. (...) Já na declaração de inconstitucionalidade parcial sem redução de texto não há dúvidas sobre a interpretação do dispositivo. Só se fiscalizam as hipóteses de sua aplicação, isto é, situações
} 
âmbito de aplicação que a norma, em tese, comportaria, seja fixando a(s) única (s) interpretação(ões) que se compatibiliza(m) com a Constituição, seja excluindo expressamente da aplicação da norma algumas hipóteses que a maculariam de inconstitucionalidade. ${ }^{136}$ Há, novamente, uma semelhança quanto aos efeitos práticos da atuação do Tribunal, o que leva inclusive alguns autores a afirmarem haver alguma complementariedade entre os institutos. Nesse sentido, afirma Alexandre de Moraes:

\begin{abstract}
Apesar de a doutrina apontar as diferenças entre a interpretação conforme a Constituição - que consiste em técnica interpretativa - e a declaração de inconstitucionalidade parcial sem redução de texto - que configura técnica de decisão judicial -, entendemos que ambas as hipóteses se completam, de forma que diversas vezes, para se atingir uma interpretação conforme a Constituição, o intérprete deverá declarar a inconstitucionalidade de algumas interpretações possíveis do texto legal, sem contudo alterá-lo gramaticalmente. ${ }^{137}$
\end{abstract}

A despeito do debate doutrinário, parece indiscutível que tanto a interpretação conforme - aplicada em sede de controle abstrato de constitucionalidade - quanto a declaração de nulidade parcial sem redução de texto atribuem verdadeiro poder político ao Supremo Tribunal Federal, na medida em que lhe permitem redefinir as hipóteses de aplicação e interpretação da norma. Conforme pondera Virgílio Afonso da Silva, especificamente quanto à interpretação conforme, ela pode aumentar o desgaste entre Judiciário e Legislativo, dada a possibilidade que abre para que o Judiciário busque “corrigir" a norma impugnada, impondo interpretações que descaracterizem as hipóteses desejadas pelo legislador. ${ }^{138}$ No mesmo sentido, Gilmar Ferreira Mendes afirma que não compete ao Tribunal, pela interpretação conforme, buscar melhorar ou aperfeiçoar o texto normativo, concluindo que qualquer intervenção nesse sentido acarreta um prejuízo mais drástico à função legiferante que a mera declaração de nulidade do texto normativo, dado que nesta última hipótese remanesce ao legislador a possibilidade de apreciar e regulamentar novamente a questão. ${ }^{139}$

que podem compor a premissa menor do silogismo jurídico. Na medida em que o dispositivo se aplica em algumas hipóteses, temos inconstitucionalidade. Nas demais hipóteses não há problema." DIMOULIS, Dimitri; LUNARDI, Soraya, op. cit., pp. 273-274.

${ }^{136}$ MENDES, Gilmar Ferreira. Jurisdição constitucional: o controle abstrato de normas no Brasil e na Alemanha, op. cit., pp. 354-355.

${ }^{137}$ MORAES, Alexandre de. Constituição do Brasil interpretada e legislação constitucional. $8^{a}$ edição. São Paulo: Atlas, 2011, p. 2237.

${ }^{138}$ SILVA, Virgílio Afonso da. "Interpretação Conforme a Constituição: entre a trivialidade e a centralização judicial”, in: Revista Direito GV, v. 2, n.1 (jan./jul. 2006), pp. 203-205.

${ }_{139}$ MENDES, Gilmar Ferreira. Jurisdição constitucional: o controle abstrato de normas no Brasil e na Alemanha, op. cit., p. 290. 
Com motivos, portanto, a doutrina e a jurisprudência buscam estabelecer limites para a interpretação conforme, reconhecendo que não se pode, por esse método, violar a literalidade do texto normativo nem alterar significativamente a intenção original do legislador ${ }^{140}$. Não obstante, inegável que esses instrumentos abrem espaço para que a Corte ultrapasse os limites de sua função de controle, pretendendo verdadeiramente melhorar e readequar o texto normativo mediante fixação de certas interpretações, com que lança mão de decisões com efeitos aditivos - na medida em que adicionam à norma interpretada outros elementos normativos não previstos expressamente pelo legislador, ainda que seja no sentido de condicionar e restringir sua aplicação. Sobressaem, nesses casos, os efeitos normativos ínsitos às decisões que restringem a polissemia normativa. $\mathrm{Na}$ discussão a respeito da extensão da utilização desse instrumento assume relevância, mais uma vez, a política institucional da Corte, que pode, ao fim e ao cabo, determinar o quantum de competência normativa possui em casos de proceder à interpretação conforme ou a declaração de nulidade parcial sem redução de texto. ${ }^{141}$

Deve ser ainda ressaltado que, tanto no âmbito da ação direta de inconstitucionalidade quanto no da arguição de descumprimento de preceito fundamental, a regulamentação infraconstitucional (respectivamente, leis n. 9.868 e n. 9.882, ambas de 1999) permite à Corte que, ao reconhecer a inconstitucionalidade, restrinja os efeitos da decisão, para que a norma atacada apenas deixe de viger a partir do trânsito em julgado da decisão ou de outro termo inicial fixado pela Corte. Estipula-se, assim, a possibilidade de declaração de inconstitucionalidade, em controle abstrato, com efeitos ex nunc, o que robustece o papel político do Supremo Tribunal Federal. Conforme ensina Manoel Gonçalves Ferreira Filho a esse respeito,

\footnotetext{
o controle de constitucionalidade assumiu um caráter político e (...) nele se pretende que o Supremo Tribunal Federal atue como órgão político.

(...)

A atribuição de eficácia ex nunc ou a partir de um determinado momento à decisão que reconhece a inconstitucionalidade pressupõe duas condições: uma, formal, ser tomada pelo quórum de dois terços dos Ministros do Supremo Tribunal Federal; outra, material, ocorrerem "razões de segurança ou de excepcional interesse social".
}

\footnotetext{
${ }^{140}$ Idem, ibidem, p. 349.

141 "Esforça-se a doutrina em vislumbrar limites à interpretação conforme à Constituição. Desse modo, falase que o uso do método interpretativo pelos tribunais não pode tornar o preceito normativo privado de função útil, contrariar a literalidade de seu enunciado, nem desvirtuar o manifesto sentido que lhe pretendeu dar o legislador. Trata-se, porém, de restrições que, para revelar alguma valia, dependem de uma postura de autorestrição (self-restraint) dos órgãos de jurisdição constitucional." LEAL, Roger Stiefelmann. $O$ efeito vinculante na jurisdição constitucional, op. cit., p. 98.
} 
A última é incontestavelmente uma apreciação de conveniência e oportunidade de mérito, no sentido administrativo do termo. É uma apreciação tipicamente política. E subjetiva (...).

(...)

Disto tudo decorre, mais uma vez, a conclusão de que o Supremo Tribunal Federal se torna uma terceira Câmara do Poder Legislativo. ${ }^{142}$

Compete ao Tribunal, assim, proceder a ponderações a respeito da adequação da eficácia da inconstitucionalidade, com o que atua como verdadeiro órgão com poderes normativos capazes de definir e condicionar a vigência temporal de normas reconhecidamente inconstitucionais.

No campo da ação declaratória de constitucionalidade, tem-se, de início, que o Supremo Tribunal Federal pode atuar como instância confirmadora das escolhas políticas feitas pela maioria governante, ao referendar a validade de uma decisão política de âmbito federal cuja constitucionalidade seja contestada perante tribunais inferiores. Decisões nesse sentido projetam não apenas seu efeito jurídico natural, no sentido de evitar novos questionamento da norma cuja constitucionalidade foi declarada por essa ação própria e de por termo aos questionamentos em controle concreto em curso, mas igualmente um efeito social no sentido de atribuir maior legitimidade a atos normativos que levantem questionamentos de sua constitucionalidade. O papel da cúpula do Judiciário como órgão de reforço a serviço de grupos dominantes, conforme cogitam Ran Hirschl ${ }^{143}$ e Robert Dahl $^{144}$, resta evidenciado. Nesse sentido, afirma Oscar Vilhena que

[e]ssa atribuição aumenta os poderes do Supremo Tribunal Federal enquanto
agência governamental, pois declarada a constitucionalidade de uma norma que
tem a sua legitimidade combatida nos tribunais inferiores, esta declaração serve
como chancela legitimadora do ato emitida pelo Tribunal, tornando a norma
imune a qualquer impugnação. (...) A perda da legitimidade política de um ato,
decorrente de sua inconstitucionalidade ainda não declarada, pode ser reparada
por uma ação do Supremo Tribunal Federal, emprestando a sua autoridade de
órgão encarregado pela guarda da Constituição, com o objetivo de legitimar o

${ }^{142}$ FERREIRA FILHO, Manoel Gonçalves. "O sistema constitucional brasileiro e as recentes inovações no controle de constitucionalidade (leis $\mathrm{n}^{\circ}$ 9.868, de 10 de novembro e $\mathrm{n}^{\circ}$ 9.882, de 3 de dezembro de 1999).", in: Revista de Direito Administrativo, n. 220 (abr./jun. 2000), p. 12 (realces no original). O autor ainda defende, nesse mesmo artigo, que o legislador infraconstitucional extrapolou sua competência ao atribuir efeito erga omnes às decisões de inconstitucionalidade, seja em ação direta de inconstitucionalidade ou em arguição de descumprimento de preceito fundamental, dado que a Constituição Federal apenas teria atribuído vinculatividade e eficácia contra todos nas ações declaratórias de constitucionalidade. Idem, ibidem, pp. 12 e 14/15. Essa discussão, entretanto, restou parcialmente superada pela Emenda Constitucional n. 45, de 2004, que atribuiu nova redação ao $\S 2^{\circ}$ do artigo 102 da Constituição Federal, estendendo o efeito erga omnes também às decisões proferidas em ações diretas de inconstitucionalidade.

${ }^{143}$ HIRSCHL, Ran. Towards juristocracy: the origins and consequences of the new constitutionalism, op. cit., pp. 31 e ss.

${ }^{144}$ DAHL, Robert. "Decision-making in a democracy: the Supreme Court as a national policy-maker" in: Journal of Public Law, n. 6 (1957), p. 293. 
referido ato e ao mesmo tempo afastar do judiciário o seu controle por intermédio da via difusa. ${ }^{145}$

Há ainda outro efeito potencial importante a ser considerado, no contexto da definição de políticas fundamentais, em declarações de constitucionalidade proferidas pelo Supremo Tribunal Federal. Em casos de ações diretas de inconstitucionalidade ou mesmo em arguições de descumprimento de preceito fundamental, o reconhecimento do desvalor constitucional da norma impugnada, quando revestida de uma declaração expressa de inconstitucionalidade - excetuada, portanto, e conforme o caso, a hipótese em que se atribui interpretação conforme a Constituição -, acarreta a retirada da norma e do respectivo enunciado do ordenamento. Há um efeito normativo claro, no sentido de criar um novo "vazio" no ordenamento, que pode ser livremente preenchido pelo legislador mediante nova regulamentação da matéria. O mesmo não ocorre em hipótese de procedência de ação declaratória de constitucionalidade, dado que, aqui, há apenas a reafirmação da validade da norma, sem qualquer alteração normativa, ipso facto, no ordenamento jurídico. A doutrina debate, entretanto, a respeito da possibilidade de reapreciação da matéria, i.e., de se a norma, após ter sua constitucionalidade declarada, seria passível de impugnação mediante ação direta de inconstitucionalidade e de nova apreciação pelo Supremo Tribunal Federal. O ponto de indagação recai sobre a extensão dos efeitos erga omnes e da vinculatividade da decisão, no sentido de se saber se incidem nesta os efeitos próprios da coisa julgada material. ${ }^{146}$

Ante a inexistência de parâmetro constitucional ou legal que resolva a matéria, resta ao próprio Supremo Tribunal Federal definir sua competência para reapreciação da matéria, bem como as hipóteses de seu cabimento, o que por sua vez permite que a Corte condicione as possibilidades de atuação de grupos políticos e sociais que visem a questionar decisões políticas previamente tomadas. Em um extremo, pode o Supremo Tribunal Federal engessar as vias de acesso ao questionamento de políticas majoritárias não obstante sobrevenham alterações fáticas, políticas e sociais relevantes que

\footnotetext{
${ }^{145}$ VIEIRA, Oscar Vilhena. Supremo Tribunal Federal: jurisprudência política, op. cit., pp. 89-90.

${ }^{146}$ Gilmar Ferreira Mendes conclui que "declarada a constitucionalidade de uma lei, ter-se-á de concluir pela inadmissibilidade de que o Tribunal se ocupe, uma vez mais, da aferição de sua legitimidade, ressalvadas as hipóteses de significativa mudança das circunstâncias fáticas ou de relevante alteração das concepções jurídicas relevantes.” MENDES, Gilmar Ferreira. Jurisdição constitucional: o controle abstrato de normas no Brasil e na Alemanha, op. cit., pp. 359-362. Elival da Silva Ramos, por sua vez, entende como inconveniente a pretensão de se atribuir efeitos de coisa julgada às decisões de procedência em ação declaratória de inconstitucionalidade. RAMOS, Elival da Silva. Controle de constitucionalidade no Brasil: perspectivas de evolução, op. cit., pp. 413-419.
} 
recomendem a revisão da constitucionalidade da norma anteriormente chancelada pelo Tribunal. No mais, pela falta de critérios objetivos que definam a questão, a Corte pode acabar por estabelecer parâmetros pouco claros, que lhe permitem rever a decisão de constitucionalidade e seus efeitos com base em seus próprios critérios de conveniência e adequação, o que por sua denota um viés claramente político de atuação. ${ }^{147}$ Ao fim e ao cabo, portanto, o Supremo Tribunal Federal acaba por avocar para si o poder de determinar o grau de imunização da norma. ${ }^{148}$

O controle abstrato das omissões constitucionais talvez seja a seara em que a influência política do Supremo Tribunal Federal seja menos perceptível. ${ }^{149} \mathrm{O}$ regramento constitucional estabelece que, declarada a inconstitucionalidade por omissão que impeça tornar efetiva norma constitucional, o Poder competente deverá ser cientificado para que adote as medidas necessárias, que no caso da Administração Pública deverá suprir a omissão em trinta dias. ${ }^{150}$ Considerando que a Constituição Federal fixa prazo para cumprimento da decisão apenas para os órgãos administrativos, o entendimento da doutrina caminha no sentido de que se a omissão for do legislador, não há prazo específico para cumprimento da determinação da Corte - muito embora o Supremo Tribunal Federal já tenha entendido pela possibilidade de fixação de prazo para o Legislativo, desde que superior àqueles trinta dias e desde que leve em consideração a duração razoável do processo legislativo. ${ }^{151}$

Inexiste, entretanto, regramento constitucional ou infraconstitucional que estabeleça alternativas, do ponto de vista da completude jurídica do ordenamento, para o eventual não cumprimento da determinação do Supremo Tribunal Federal pelo respectivo órgão omissivo - há, quando muito, a possibilidade de responsabilização funcional, em especial em caso de órgão da Administração Pública, em razão do descumprimento de

\footnotetext{
${ }^{147}$ Segundo aponta Lucas Catib de Laurentiis, a "abertura da possibilidade de o Supremo rever os julgamentos por ele proferidos em Ações Declaratórias de Constitucionalidade confedere um poder potencialmente absoluto a esta Corte. Isso não decorre simplesmente de a expressão 'situação de fato', utilizada com frequência para fundamentar a revisão destes julgados, conter uma amplitude semântica indeterminada e possivelmente indeterminável. Decorre também do fato de o Supremo manipular os conceitos e os efeitos da declaração de constitucionalidade ou inconstitucionalidade conforme a conveniência do momento." LAURENTIIS, Lucas Catib de. "Efeitos do julgamento e coisa julgada em Ações Declaratórias de Constitucionalidade: ativismo judicial não declarado", in: AMARAL JÚNIOR, José Levi Mello do (coord.). Estado de Direito e ativismo judicial. São Paulo: Quartier Latin, 2010, pp. 195-196.

${ }^{148}$ Idem, ibidem, p. 197.

${ }^{149}$ Nesse sentido, destaca José Afonso da Silva: "só 11 foram ajuizadas, desde 1998 até 31.12.2010, das quais só 3 foram conhecidas e julgadas, nenhuma julgada procedente, uma improcedente, duas não conhecidas, oito aguardam julgamento". SILVA, José Afonso da., op. cit., p. 157.

${ }^{150}$ Cf. artigo $103, \S 2^{\circ}$, da Constituição Federal.

${ }^{151}$ DIMOULIS, Dimitri; LUNARDI, Soraya, op. cit., p. 138.
} 
mandamento judicial. Ademais, deve ser considerado que, em certa medida, e ainda quando a procedência da ação direta de inconstitucionalidade por omissão envolva o reconhecimento de que a necessidade de efetividade da norma constitucional imponha um dever de sua regulamentação - e não apenas uma faculdade -, se essa omissão for legislativa, haverá sempre um impasse em se esbarrar nas próprias ponderações de conveniência e oportunidade do Legislativo quanto à produção normativa. A imposição, por decisão judicial, de obrigação de se proceder à complementação normativa soa como uma provocação da atividade legiferante que tolhe o direito de escolha do legislador.

Seja como for, a falta de regulamentação quanto a alternativas para a persistência da incompletude do ordenamento cria uma situação em que a decisão proferida pode não resolver o problema da omissão aventada. Entende-se que não competiria ao Supremo Tribunal Federal avocar a competência de completar a lacuna legislativa ou regulamentar ainda que a título precário -, dado que nessa atividade reside verdadeira função legislativa. ${ }^{152}$ Não obstante, e da mesma forma como se viu em outros instrumentos de controle, é a própria Corte quem acaba por estabelecer os critérios e os limites dos efeitos das decisões que profere em sede abstrata de controle, o que não impede, em tese, que, ao adotar um posicionamento mais ativista, busque encampar a atividade normativa - ainda que provisoriamente - para suprir o não cumprimento do mandamento determinado na decisão que reconhece a inconstitucionalidade por omissão.

Cumpre ainda mencionar dois outros instrumentos que, muito embora não integrem a sistemática do controle abstrato de normas, têm permitido ao Supremo Tribunal Federal atuar de maneira incisiva e decisiva na definição de macropolíticas estatais.

O primeiro deles é o mandado de injunção, já mencionado no capítulo precedente. Inicialmente, a jurisprudência do Supremo Tribunal Federal equiparava-o, quanto a seus efeitos, à ação direta de inconstitucionalidade por omissão, i.e., no sentido de que a procedência do pedido levava à prolação de mandamento para que o órgão competente editasse a norma necessária para o exercício do direito constitucional em questão, estando a Corte impedida de regulamentar a matéria. ${ }^{153}$ Entretanto, o Supremo Tribunal Federal

\footnotetext{
${ }^{152}$ Gilmar Ferreira Mendes já sustentou que diante de omissões normativas reconhecidas pelo Supremo Tribunal Federal, a Corte estaria impossibilitada de editar normas, ainda que de caráter provisório, em substituição ao órgão legiferante, dado que isso seria incompatível com princípios sensíveis da Constituição - em especial, com a ideia de separação de Poderes. MENDES, Gilmar Ferreira. Jurisdição constitucional: o controle abstrato de normas no Brasil e na Alemanha, op. cit., pp. 374-377.

${ }^{153}$ Idem, ibidem, loc. cit. No mesmo sentido, "Finalmente, registra-se a tese que contou, durante anos, com o beneplácito do Supremo Tribunal Federal, segundo a qual a procedência da reportada ação constitucional
} 
reviu sua jurisprudência sobre a matéria, readequando os limites e efeitos da ação constitucional. Aponta Elival da Silva Ramos que, nos mandados de injunção n. 6709/ES ${ }^{154}$, n. $708-0 / \mathrm{DF}^{155}$ e n. $712-8 / \mathrm{PA}^{156}$, que versavam sobre o exercício do direito de greve de servidores públicos, e cuja omissão na regulamentação já havia sido reconhecida pelo próprio Supremo Tribunal Federal em outros mandados de injunção, a Corte admitiu que lhe competiria regulamentar, ainda que de maneira provisória, mas com eficácia erga omnes, o vazio normativo, mediante especificação do modo de exercício do direito em questão. $^{157}$

Não há, ainda, uma sedimentação clara da matéria na jurisprudência da Corte, nem dos limites de sua atividade normativa atípica e dos casos e hipóteses que permitem lançar mão dessa competência. Ainda assim, tem-se aqui um exemplo de ampliação da competência da Corte e de seu papel na definição de políticas de relevância nacional mediante mudanças ocorridas no próprio entendimento do órgão a respeito de suas competências e das finalidades típicas do remédio constitucional sob análise. Conquanto o citado autor não vislumbre nas decisões proferidas daqueles mandados de injunção verdadeiro ativismo do Supremo Tribunal Federal, dado que a decisão encontraria baliza na própria interpretação sistemática da Constituição, a conclusão a que chega também aponta que a assunção dessa nova competência abre espaço, inegavelmente, para o desenvolvimento de uma jurisprudência mais ativista. ${ }^{158}$

Ao manejar os elementos de admissibilidade da demanda de injunção, o que inclui a definição tanto dos direitos passíveis de tutela por esse remédio constitucional quanto da efetividade do provimento ao final prolatado, o Supremo Tribunal Federal pode, em última análise, ampliar sua participação política mediante exercício de atividade verdadeiramente

redunda, na maioria das vezes, em provimento de natureza constitutiva, porém com o sentido de meramente constituir em mora o órgão ou entidade inerte, dando-lhe ciência da omissão, a fim de que possam ser adotadas as providências necessárias ao suprimento do vazio normativo. (...) Com essa exegese do Texto Magno, o Supremo Tribunal Federal praticamente equiparou o mandado de injunção à ação direta de inconstitucionalidade por omissão. Ambos seriam instrumentos destinados ao enfrentamento da omissão constitucional, mas não autorizam ao Poder Judiciário a substituição do órgão responsável por dar plenitude de eficácia às normas constitucionais, servindo apenas para estimulá-lo ou, no caso de órgão administrativo, para compeli-lo a agir." RAMOS, Elival da Silva. Controle de constitucionalidade no Brasil: perspectivas de evolução, op. cit., pp. 317-318. Em outra obra, Elival da Silva Ramos ressalta que, ainda enquanto majoritário esse entendimento, por duas oportunidades o Supremo Tribunal Federal admitiu, mesmo que de forma mais restrita, a possibilidade de proferir regulamentação normativa para a omissão questionada. RAMOS, Elival da Silva. Ativismo judicial: parâmetros dogmáticos, op. cit., p. 301.

${ }^{154}$ Relator Ministro Maurício Corrêa, j. em 25.10.2007.

155 Relator Ministro Gilmar Mendes, j. em 25.10.2007.

${ }^{156}$ Relator Ministro Eros Grau, j. em 25.10.2007.

${ }^{157}$ RAMOS, Elival da Silva. Ativismo judicial: parâmetros dogmáticos, op. cit., pp. 302-303.

${ }^{158}$ Idem, ibidem. p. 303. 
normativa, ainda que seja subsidiária e provisória, mas que tem seus efeitos ampliados pela pretensa eficácia erga omnes de suas decisões. Há aqui, sem dúvidas, uma reestruturação jurisprudencial dos limites das atividades e das funções entre os Poderes, mesmo que revestida sob um discurso jurídico-formal, o que pode levar a um desequilíbrio institucional e a um impacto negativo ao princípio da separação de Poderes.

Por fim, há também que se mencionar a figura da súmula vinculante. O instituto foi estabelecido pela Emenda Constitucional n. 45, de 2004, e visa a permitir a uniformização da jurisprudência mediante edição de enunciados sumulares dotados de vinculatividade contra todos os órgãos do Judiciário e da Administração Pública. De um lado, isso impede a prolação de decisões judiciais divergentes - que, em ocorrendo, podem ser impugnadas mediante reclamação constitucional ${ }^{159}$ - e, de outro, desestimula a produção de atos, pela Administração Pública, que contrarie a diretriz sumular - que por sua vez poderiam dar causa a inúmeras demandas judiciais. A despeito de seu objetivo de evitar a proliferação de demandas desnecessárias, dada a pacificação do entendimento sobre determinada matéria junto à cúpula do Judiciário, é inegável que o instituto acabou por atribuir verdadeiros poderes normativos ao Supremo Tribunal Federal.

Os enunciados sumulares não vinculantes encerram, em síntese, interpretações dadas pelos Tribunais a respeito da aplicação de algum ato normativo. Decorrem, assim, do processo hermenêutico e da sedimentação de um entendimento em um Tribunal, sendo inegável que surgem, portanto, também de um processo de criação do Direito, na medida em que são resultado de decisões proferidas em casos concretos. Muito embora acabem por definir e delimitar, ainda que no entendimento do respectivo Tribunal, o modo de ser de determinadas relações jurídicas e a forma de aplicação de determinadas normas, apenas sinalizam qual o entendimento preponderante em um órgão jurisdicional, não impedindo nem limitando a atividade hermenêutica dos demais órgãos jurisidicionais, e tampouco condicionando a atuação da Administração Pública. Não sendo de observância obrigatória, em verdade não inserem novos elementos normativos no ordenamento jurídico.

A situação modifica-se completamente ao se atribuir vinculatividade a tais enunciados: a definição que trazem em si quanto à interpretação de determinado enunciado normativo acaba por integrar o próprio âmbito de incidência da norma, que tem condicionada e limitada suas possibilidades de interpretação e aplicação por outros órgãos. Há, inerente isso, um elemento de verdadeira criação normativa que extrapola o âmbito da

${ }^{159}$ Cf. artigo 103-A, $\S 3^{\circ}$, da Constituição Federal de 1988. 
criação do Direito que é idiossincrático ao processo hermenêutico feito pelo julgador: as súmulas vinculantes não são apenas decorrência de um processo criativo de Direito relativo à aplicação de normas para a resolução de uma demanda específica -, mas é ela própria um elemento de criação e inovação normativa, dada a obrigatoriedade de sua observância e seu caráter geral e abstrato.

Há ainda outro elemento a ser considerado, relativo à atribuição de discricionariedade para o Supremo Tribunal Federal criar normas. Segundo lição de Elival da Silva Ramos:

\begin{abstract}
Se a jurisdição pode ser vista como atividade de criação de normas para os casos concretos ou até mesmo de normas abstratas, em se cuidando de controle de constitucionalidade principal, a prevalência do caráter de aplicação do direito se infere da circunstância de que não tem o juiz a iniciativa de criação dessas normas e, complementarmente, não lhe é dada a opção de criá-las ou não. Não é o que ocorre com o exercício da competência do Supremo Tribunal Federal para editar súmulas de jurisprudência de observância compulsória, que se faz ao arrepio do princípio da inércia da jurisdição e, o que é ainda mais significativo, do princípio da inafastabilidade. ${ }^{160}$
\end{abstract}

Em síntese, as súmulas vinculantes, portanto, permitem uma ingerência direta na definição de políticas de âmbito nacional, dado que abrem espaço para que o Supremo Tribunal Federal determine, com observância obrigatória, a forma de interpretação e aplicação de normas editadas por outros Poderes, com o que reduz seu âmbito de incidência mediante a adição de outros elementos de caráter geral e abstrato que restringem a polissemia do enunciado legal - que explícita ou implicitamente é objeto de súmula. ${ }^{161}$

Mais que isso, viabilizam também um certo rearranjo da sistemática do controle difuso de constitucionalidade. Decisões proferidas pelo Supremo Tribunal Federal em controle concreto de constitucionalidade produzem efeitos apenas inter partes, dependendo de ato do Senado para que se atribuam efeitos mais abrangentes à decisão, conforme artigo 52, X, da Constituição Federal - no sentido de, se for o caso, suspender a eficácia da norma. As súmulas vinculantes permitem que a Corte, potencialmente, dê um bypass no procedimento estipulado na Constituição Federal, na medida em que pode estender os efeitos do controle concreto de constitucionalidade mediante edição de ato normativo que

\footnotetext{
${ }^{160}$ RAMOS, Elival da Silva. Controle de constitucionalidade no Brasil: perspectivas de evolução, op. cit., p. 375

${ }^{161}$ Situação que é potencializada e tem seus efeitos ampliados ao se considerar a possível extensão da vinculatividade à ratio decidendi dos julgados que embasam a prolação da súmula vinculante. Nesse sentido, ver: LEAL, Roger Stiefelmann. O efeito vinculante na jurisdição constitucional, op. cit., pp. 174-176.
} 
impeça a aplicação da norma, ou mesmo que determine uma interpretação conforme a Constituição. ${ }^{162}$

Cumpre ainda fazer um último apontamento, no tocante aos efeitos das decisões proferidas em sede de controle concreto de normas pelo Supremo Tribunal Federal. Conforme acima mencionado, tais decisões produzem efeitos inter partes, razão pela qual, ainda quando digam respeito a questões sensíveis, a influência e o poder político da Corte ficam mitigados em razão da restrição dos efeitos da decisão. Não obstante, o próprio Tribunal vem desenhando entendimento no sentido da objetivação desses efeitos, independentemente da atuação do Senado Federal. É o que defende o Ministro Gilmar Mendes, relator da reclamação n. 4.335/AC, em julgamento ainda pendente de finalização. Sustenta o relator, que já contou com o apoio do voto do Ministro Eros Grau (ora aposentado), que houve uma mutação constitucional que, grosso modo, suprimiu o quanto determinado pelo artigo 52, X, da Constituição Federal. Vislumbra-se aí uma tentativa de o próprio Supremo Tribunal Federal ampliar os efeitos de suas decisões. O voto é justificado no escopo de atribuir maior uniformidade às decisões e paute-se na ideia de que, uma vez reconhecida a inconstitucionalidade pela Corte, tal inconstitucionalidade independe da via de julgamento (concreta ou abstrata), razão pela qual deveria ter efeito amplo. No entanto, não há como negar que se pretende proceder ao reconhecimento de uma mutação constitucional mediante alteração (in casu, supressão) de texto expresso da Lei Maior sem qualquer reconhecimento prévio de inconstitucionalidade, o que, segundo a melhor doutrina, não é admissível. ${ }^{163}$ Tem-se aí exemplo claro de como a própria Corte pode moldar os instrumentos interpretativos - a exemplo da interpretação conforme, de que já se falou - e os efeitos dos mecanismos de controle. ${ }^{164}$

Conforme se buscou demonstrar, sob a égide da Constituição de 1988 houve o aumento expressivo das competências do Supremo Tribunal Federal no que diz respeito à tomada de decisões com implicações normativas que assumem efeitos abrangentes, na

\footnotetext{
${ }^{162}$ A esse respeito, ver: LEAL, Roger Stiefelmann. "A incorporação das súmulas vinculantes à jurisdição constitucional brasileira: alcance e efetividade em face do regime legal da repercussão geral e da proposta de revisão jurisprudencial sobre a interpretação do art. 52, X, da Constituição", in: Revista de Direito Administrativo, v. 261 (set./dez. 2012), pp. 185-186.

163 "A mutação constitucional por via interpretativa não atinge a letra da Constituição; também, não altera o conteúdo positivado expressamente na norma constitucional. Apanha, porém, o significado, o sentido ou o alcance das disposições constitucionais. A mudança da letra do texto constitucional, nas Constituições rígidas, somente se admite, quando decorrente de reforma, mediante processo previsto na própria Constituição.” FERRAZ, Anna Candida da Cunha. Processos informais de mudança da Constituição: mutações constitucionais e mutações inconstitucionais. São Paulo: Max Limonad, 1986, p. 58.

${ }^{164}$ Para uma análise do julgamento da reclamação n. 4.335/AC, ver: DIMOULIS, Dimitri; LUNARDI, Soraya, op. cit., pp. 281 e ss.
} 
medida em que possuem eficácia erga omnes e são dotadas de vinculatividade. Os diversos instrumentos que lhe permitem impor posicionamentos a respeito da interpretação do nosso ordenamento jurídico - seja no âmbito do controle abstrato de normas, seja no âmbito do controle de omissões normativas por via de mandado de injunção e até mesmo pela fixação de entendimentos sumulares vinculantes -, a despeito de possuírem regramento constitucional e/ou legal, têm seus limites e efeitos definidos pela própria Corte, dado ser esta a instituição responsável por seu manejo e aplicação. O efeito natural é que, a depender da política institucional do órgão, tais institutos podem ser usados com um escopo político mais amplo, de modo a permitir uma participação efetiva do Supremo Tribunal Federal no processo de definição de políticas de relevância nacional.

Algumas modificações jurisprudenciais no âmbito do Supremo Tribunal Federal, a exemplo do ocorrido com o mandado de injunção e no voto do Ministro Gilmar Mendes na reclamação n. 4.335/AC, denotam um movimento no sentido de se buscar expandir os efeitos de suas decisões, bem como um maior conforto da própria Corte em adentrar no campo verdadeiramente normativo. Do mesmo modo, a possibilidade de o próprio Supremo Tribunal Federal determinar, v.g., limites a institutos como o da interpretação conforme, bem como parâmetros para reapreciação de decisões declaratórias de constitucionalidade, demonstra que a Corte, ao fim e ao cabo, pode estabelecer o quantum de poder político pode e deve possuir, bem como fixar critérios que permitam maior ou menor acesso de legitimados ao sistema de controle de constitucionalidade. $O$ fiel da balança do equilíbrio do princípio da separação dos Poderes acaba, assim, por residir em grande medida na própria atuação da Corte e nos limites que ela atribui ao exercício dos instrumentos constitucionais que são inseridos em seu âmbito de atuação.

2.1.3 Mudanças na política institucional do Supremo Tribunal Federal e o surgimento de um novo escopo de atuação.

Conforme já afirmado anteriormente, a política institucional das Cortes Constitucionais acaba por definir a intensidade com a qual a cúpula dos Judiciários nacionais lança mão dos instrumentos de controle normativo e participa dos rumos da política nacional. Não poderia ser diferente, no Brasil, com o Supremo Tribunal Federal, e os elementos apresentados nos capítulos precedentes dão conta de que nosso ordenamento 
constitucional atribui uma série de instrumentos com potencialidade política à Corte, de modo que os limites de sua participação no controle de constitucionalidade são traçados de acordo com sua própria interpretação sobre o seu papel frente à proteção da Constituição e à garantia de sua efetividade.

Nesse sentido, os últimos vinte e cinco anos marcaram um processo de rápida expansão do Supremo Tribunal Federal na definição de políticas de relevância nacional, catalisado pela ampliação em seu rol de competências e pela forte inclinação que vem demonstrando em atuar nessas questões. Embora seja um tribunal que também possui competências ordinárias para julgar casos concretos em última e definitiva instância, e ainda que não tenha sido estruturado como verdadeira Corte Constitucional de natureza política, é indiscutível o processo de politização por que passou e tem passado o Supremo Tribunal Federal. Quando provocado a intervir em matéria política, atua como verdadeira Corte Constitucional, realizando ponderações a respeito das escolhas normativas feitas pelos demais Poderes.

Essa atuação, por sua vez, vem apresentando mudanças significativas desde o início do século XXI, de modo que, valendo-se da terminologia empregada por Mark Tushnet, esse período parece ter-nos colocado diante de uma nova ordem constitucional ${ }^{165}$, em que decisões políticas fundamentais são amplamente submetidas ao crivo da Corte, que, assim, se vê diante da possibilidade de moldá-las conforme as valorações da maioria julgadora. Sua constante participação no controle de políticas legislativas de cunho nacional parece alçar o Supremo Tribunal Federal a verdadeiro partícipe de escolhas políticas sensíveis. E mais que isso, decisões recentes sobre temas polêmicos, a exemplo da união estável homoafetiva ${ }^{166}$, da utilização de células-tronco embrionárias em pesquisas ${ }^{167}$ e do abortamento de fetos anencéfalos ${ }^{168}$ - casos que serão posteriormente analisados - mostram que a Corte se vê mais confortável em se tornar um local de debate político e de apresentar suas razões quanto aos princípios constitucionais em jogo.

\footnotetext{
165 "Por ordem (ou regime) constitucional, eu me refiro a um modelo institucional minimamente estável por meio do qual as decisões fundamentais de uma nação são tomadas ao longo de certo período, e aos princípios que guiam essas decisões." TUSHNET, Mark. The new constitutional order, op. cit., p. 1. Em sentido contrário ao que temos vivenciado no Brasil, o autor aponta o declínio do papel desempenhado pela atual Suprema Corte estadunidense na definição de políticas fundamentais, em contraposição à sua participação na ordem constitucional pós New Deal. Idem, ibidem, pp. 33 e ss.

${ }_{166}^{166}$ ADI n. 4.277/DF e ADPF n. 132/RJ, ambas de relatoria do Ministro Ayres Britto e j. em 05.05.2011.

${ }^{167}$ ADI n. 3.510/DF, relator Ministro Ayres Britto, j. em 29.05.2008.

${ }^{168}$ ADPF n. 54/DF. Relator Ministro Marco Aurélio Mello, j. em 12.04.2012.
} 
Há que se destacar que a forte atuação do Supremo Tribunal Federal nesta seara não está, em todo e qualquer caso, vinculada a decisões claramente ativistas. Evidente que casos como a da instituição jurisprudencial da fidelidade partidária ${ }^{169}$, que cria uma hipótese nova de perda de mandato parlamentar não prevista no rol do artigo 55 da Constituição e estabelece critérios em que a troca de partido seria aceitável, bem como a fixação de parâmetros a serem observados pelo Poder Público na demarcação de terras indígenas ${ }^{170}$, por exemplo, transbordam os limites "normais" da atuação do Supremo Tribunal Federal - ainda que não estejam imediatamente ligadas a hipóteses de controle abstrato de normas. Outras decisões, no entanto, muito embora reflitam no curso de políticas fundamentais, parecem estar consignadas dentro do espaço trivial de atuação da Corte Constitucional, inserindo-se nos parâmetros normais decorrentes de sua função de controle, a exemplo da decisão que declarou a inconstitucionalidade da cláusula de desempenho no direito pátrio ${ }^{171}$, em que a maioria da Corte entendeu que o preceito seria incompatível com nosso sistema partidário.

Mesmos nesses casos em que não se vislumbra forte ativismo, percebe-se um animus proativo do Supremo Tribunal Federal em conformar decisões políticas à sua leitura a respeito do texto constitucional. Nesse sentido, percebe-se que assumiu o correspondente risco institucional de substituir as ponderações legislativas feitas pelos entes políticos, o que somente ocorre quando a Corte já se veja suficientemente legitimada perante as demais instituições sociais e estatais.

Não obstante, a doutrina aponta que o Supremo Tribunal Federal tem, mais recentemente, assumido uma postura mais ativista, o que acaba por reverberar em suas concepções acerca dos parâmetros de sua atuação. A ampliação dos efeitos e implicações do mandado de injunção, de que já se tratou, é exemplo disso. Do mesmo modo, $(i)$ a jurisprudência recente da Corte a respeito de efetividade de direitos de cunho social, atribuindo-lhes eficácia plena e imediata ${ }^{172}$, (ii) a utilização da modulação de efeitos em declarações de inconstitucionalidade, que lhe permite fixar e delimitar a vigência que a

\footnotetext{
${ }^{169}$ Acórdãos proferidos nos mandados de segurança ns. 26.602/DF, 26.603/DF e 26.604/DF, impetrados junto ao Supremo Tribunal Federal, j. em 4 de outubro de 2007. O entendimento foi posteriormente reafirmado no julgamento da ADI 3.999/DF, j. em 12.11.2008, em que se impugnava a constitucionalidade das resoluções n. 22.610/2007 e n. 22.733/2008 do Tribunal Superior Eleitoral, que regulamentavam a perda do mandato eletivo por infidelidade partidária e o processo de justificação de desfiliação.

${ }^{170}$ Acórdão relativo à demarcação das terras indígenas da reserva Raposa Serra do Sol (petição n. 3.388/RR, relator Ministro Ayres Britto, j. em 20.03.2009).

${ }^{171}$ ADI n. 1.351/DF, relator Ministro Marco Aurélio Mello, j. 07.10.2006.

${ }^{172}$ RAMOS, Elival da Silva. Ativismo judicial: parâmetros dogmáticos, op. cit., pp. 264 e ss.
} 
norma inconstitucional pode ter ${ }^{173}$, (iii) e mesmo a discussão sobre os efeitos do controle concreto de constitucionalidade feito pelo Supremo Tribunal Federal - conforme discutidos na já mencionada reclamação n. 4.355/AC, mostram que o Supremo Tribunal Federal vem revisitando e readequando os limites de sua competência, admitindo possuir poderes e prerrogativas que ampliam sobremaneira sua influência no contexto político e no processo de escolhas de políticas nacionais pelo Legislativo e Executivo.

Dentre os casos que permitem vislumbrar essa transição na política institucional do Supremo Tribunal Federal, há um em especial, justamente pelo longo período que levou entre a propositura da ação e sua decisão no mérito: a ação de descumprimento de preceito fundamental (ADPF) n. 54/DF ${ }^{174}$, que tratava de abortamento de fetos anencéfalos.

Em síntese, a Confederação Nacional dos Trabalhadores da Saúde buscava conferir interpretação conforme do Código Penal em face da Constituição, de modo a se reconhecer que o abortamento de feto anencefálico não caracterizaria crime nos termos do Código Penal.

Trata-se de caso que causou grande mobilização social e midiática, em especial pelas questões morais e religiosas que envolvia, o que certamente acabou também por influenciar a atuação da Corte. ${ }^{175}$

O início do julgamento da ação pelo plenário ${ }^{176}$, em sessão datada de 20 de outubro de 2004, foi marcado pela questão de ordem levantada pelo Ministro Eros Grau, a respeito da adequação da ação de descumprimento de preceito fundamental no presente caso - o que envolvia, inclusive, a discussão a respeito do cabimento de interpretação conforme nesse tipo de ação. Na oportunidade, o Ministro Carlos Britto pediu vista dos autos, tendo a questão retornada ao plenário em sessão datada de 27 de abril de 2005, quando então se passou a analisar o cabimento da via eleita.

\footnotetext{
${ }^{173}$ FERREIRA FILHO, Manoel Gonçalves. "O Papel Político do Judiciário e suas Implicações”, in: FRANCISCO, José Carlos, op. cit., p. 230.

${ }^{174}$ Relator Ministro Marco Aurélio Mello, j. em 12.04.2012.

${ }^{175}$ Quanto ao Supremo Tribunal Federal sob foco midiático, ver: FERREIRA FILHO, Manoel Gonçalves. "O Papel Político do Judiciário e suas Implicações”, in: FRANCISCO, José Carlos, op. cit., pp. 237-239.

${ }^{176}$ Que ocorreu após concessão de liminar pelo Ministro relator quando do recesso da Corte em julho de 2004, para que: (i) fossem suspensas todas as persecuções penais oriundas de abortamento na mencionada circunstância e (ii) fosse reconhecido à gestante de feto anencéfalo o direito de realizar o pretendido aborto, até que houvesse a decisão final pelo plenário do Supremo Tribunal Federal. Em sessão de 2 de agosto daquele ano, a liminar foi concedida pelo Pleno, tendo sido posteriormente revogada quando do início do julgamento da ação, em sessão de 20.10.2004.
} 
Nos debates e nos votos então proferidos restou evidenciado que a discussão a respeito de questões preliminares quanto ao cabimento da ADPF apontavam, em verdade, a um desconforto do Supremo em enfrentar a questão de mérito e de arcar com o ônus (e custos) de ter de decidir a respeito do direito fundamental pleiteado: afinal, a decisão de mérito deveria retratar uma decisão política, quer em favor da vida intrauterina (inviolável fora das hipóteses expressamente positivadas) quer em favor da dignidade da mãe, o que por sua vez poderia resultar em uma nova excludente de ilicitude no ordenamento não previsto pelo legislador.

Nesse sentido, cumpre mencionar o voto da Ministra Ellen Gracie, que aduziu, dentre outros argumentos, entendimento no sentido de que somente se poderia reconhecer a recepção ou não recepção (total ou parcial) do Direito pré-constitucional tout court, i.e., sem possibilidade de se realizar, nesta sede, interpretação conforme a Constituição. Votou, assim, pelo não conhecimento da ação, fazendo, não obstante, a seguinte ressalva quanto à atuação do Supremo Tribunal Federal:

\begin{abstract}
Entendo, Senhor Presidente, que a sociedade brasileira precisa encarar com seriedade e consciência um problema de saúde pública que atinge principalmente as mulheres das classes menos favorecidas. E deve fazê-lo por meio de seus legítimos representantes perante o Congresso Nacional, não, ao contrário, por via oblíqua e em foro impróprio, mediante mecanismos artificiosos que (...) acarretaria uma ruptura de princípios basilares, como o da separação de poderes e a repartição estrita de competência entre eles. (...)

Além do mais, contrastar, por via da ADPF, um ato normativo anterior com a Constituição atual só pode ter o efeito de concluir pela sua revogação (não recepção) no todo ou em parte (...). Nunca terá o resultado de acrescentar àquela norma anterior à ordem vigente palavras ou conteúdos novos. ${ }^{177}$
\end{abstract}

Na mesma esteira, o Ministro Carlos Velloso entendeu pela inadequação da ação para obtenção do pretendido pelo arguente da inconstitucionalidade. O Ministro enfrentou igualmente o problema da delimitação dos marcos da atuação da Corte Constitucional, aduzindo que o pedido do autor demanda atuação legislativa derivada do Parlamento, não sendo o caso de mera interpretação conforme de textos normativos plurissêmicos, mas de requerimento de criação de mais uma exculpante penal ex vi decisão judicial.

Subjacente à maioria das decisões de não conhecimento reside, na realidade, uma apreciação acerca do próprio papel do Supremo Tribunal Federal.

\footnotetext{
${ }^{177}$ Voto da Ministra Ellen Gracie na Questão de Ordem da ADPF n. 54/DF, pp. 14-15 (pp. $206-207$ do acórdão).
} 
Tais posicionamentos retratavam uma visão que, em maior ou menor grau, defendiam um posicionamento de autocontenção da Corte. Os Ministros que votaram pelo não conhecimento da ação de descumprimento de preceito fundamental pugnavam, sobretudo, pela incompetência do Supremo em criar exculpantes penais não estipuladas pelo Congresso.

Emblemáticas as afirmações do Ministro Gilmar Mendes, em debate ao final do voto do Ministro Carlos Velloso naquela questão de ordem:

\begin{abstract}
Gostaria de fazer um curto aparte. Essa questão tem sido tratada menos como uma questão ontológica, em termos de controle de constitucionalidade, e mas como uma questão de conveniência. Penso que no próprio Supremo Tribunal Federal (...) o tema foi colocado sob esse aspecto, talvez, de uma jurisprudência defensiva que enfatizava a questão na perspectiva de um excesso de numero de ações diretas de inconstitucionalidade. Mas estamos a ver que pelo menos a crise numérica do Supremo Tribunal Federal passa pelo excesso de processos de caráter individual (...). ${ }^{178}$
\end{abstract}

A maioria dos votos na questão de ordem, no entanto, foi no sentido de conhecer a ação. Como o tema acabou por ser levantado por alguns dos Ministros ao longo da sessão, mesmo os que entenderam pelo seguimento da ação de descumprimento de preceito fundamental acabaram por tecer considerações acerca do papel do Supremo Tribunal Federal.

Nesse sentido, por exemplo: o Ministro Nelson Jobim, que em voto curto e direto, defendeu ser fundamental que o Supremo coloque uma solução ao problema ali submetido, evitando-se decisões contraditórias em todo o território nacional; e o Ministro Joaquim Barbosa, que defendeu uma postura menos rígida no tocante aos critérios de admissão da referida ação constitucional, tendo em vista que o Supremo Tribunal Federal deveria estar mais atento à função primordial de

(...) conferir especial proteção a grupos minoritários (...) que, por força de sua baixa representatividade ou da situação de quase impotência com que se apresentam no processo político institucional regular, não dispõem de meios para fazer valer de forma eficaz os seus direitos. ${ }^{179}$

\footnotetext{
${ }^{178}$ Voto do Ministro Carlos Velloso na Questão de Ordem da ADPF n. 54/DF, p. 13 (p. 220 do acórdão).

${ }^{179}$ Voto do Ministro Joaquim Barbosa na Questão de Ordem da ADPF n. 54/DF, p. 8 (p. 147 do acórdão) (realces originais).
} 
O Ministro Sepúlveda Pertence, por sua vez, foi bastante enfático nos argumentos que o levam a conhecer da ação proposta. Em síntese, entende que todos os requisitos formais foram preenchidos e faz uma ressalva específica de que o pretendido pelo arguente não seria uma inovação jurisprudencial que enxertasse uma nova excludente de culpabilidade no Código Penal, mas sim que atribuísse interpretação conforme a alguns de seus dispositivos de modo que se delimitasse o âmbito da tipicidade do crime de aborto. Nesse sentido, ponderou que a única diferença vislumbrada neste caso seria a de que se estaria manejando legislação pré-constitucional, o que de forma alguma representaria qualquer obstáculo ao julgamento da ação.

O julgamento mérito da ação sob análise foi retomado em abril de 2012, tendo-se decidido por maioria de 8 votos contra 2 pela procedência da ADPF. Por certo, há que se considerar que a composição da Corte era, em parte, diferente daquela que julgou a questão de ordem, mas ainda assim se verifica da leitura dos votos um posicionamento muito mais confortável do Supremo Tribunal Federal como um todo em participar da definição de temas políticos sensíveis. Ao analisarem a questão de fundo, os Ministros que formaram a maioria apresentaram verdadeiras ponderações quanto aos princípios e valores em jogo, tendo sido recorrente a aplicação do princípio da proporcionalidade a justificar o entendimento de que o aborto terapêutico, na hipótese aventada, não deveria ser entendido como um desvalor penal. A linha argumentativa apresentada demostra claramente um novo escopo de atuação da Corte, vendo-se como partícipe do arranjo normativo nacional quando isso envolva a proteção de direitos fundamentais.

A discussão sobre os limites da atuação do Tribunal, por sua vez, conquanto tenha permeado os debates - mas em patamar mais tênue que aquele que pautou o julgamento da questão de ordem -, foi entendida como impedimento para a procedência da ação pelo Ministro Ricardo Lewandowski, que aduziu:

De fato, como é sabido e ressabido, o Supremo Tribunal Federal, à semelhança do que ocorre com as demais Cortes Constitucionais, só pode exercer o papel de legislador negativo, cabendo-lhe a relevante - e por si só avassaladora - função de extirpar do ordenamento jurídico as normas incompatíveis com o Texto Magno.

Trata-se de uma competência de caráter, ao mesmo tempo, preventivo e repressivo, cujo manejo, porém, exige cerimoniosa parcimônia, tendo em conta o princípio da intervenção mínima que deve pautar a atuação da Suprema Corte. Qualquer excesso no exercício desse delicadíssimo mister trará como consequência a usurpação dos poderes atribuídos pela Carta Magna e, em última análise, pelo próprio povo, aos integrantes do Congresso Nacional. 
Destarte, não é lícito ao mais alto órgão judicante do País, a pretexto de empreender interpretação conforme a Constituição, envergar as vestes de legislador positivo, criando normas legais, ex novo, mediante decisão pretoriana. Em outros termos, não é dado aos integrantes do Poder Judiciário, que carecem da unção legitimadora do voto popular, promover inovações no ordenamento normativo como se parlamentares eleitos fossem.

(...)

Por todo o exposto, e considerando, especialmente, que a autora, ao requerer ao Supremo Tribunal Federal que interprete extensivamente duas hipóteses restritivas de direito, em verdade pretende que a Corte elabore uma norma abstrata autorizadora do aborto eugênico nos casos de suposta anencefalia fetal, em outras palavras, que usurpe a competência privativa do Congresso Nacional para criar, na espécie, outra causa de exclusão de punibilidade ou, o que é ainda pior, mais uma causa de exclusão de ilicitude, julgo improcedente o pedido. ${ }^{180}$

Os demais Ministros, quando se ocuparam da temática, o fizeram para reafirmar a competência do Supremo Tribunal Federal em atuar nessa seara. Relevante ressaltar o voto do Ministro Gilmar Mendes, que, diferentemente do quanto afirmado no voto sobre questão de ordem pelo Ministro Sepúlveda Pertence e no voto de mérito pela Ministra Rosa Weber - que entendiam não haver na interpretação conforme uma criação normativa -, via na decisão de procedência clara intervenção do Supremo Tribunal Federal na definição das normas vigentes, o que por sua vez entendeu absolutamente pertinente aos limites de atuação do Tribunal, julgando procedente a ação:

Assim, observe-se que, nesta ADPF 54, Rel. Min. Marco Aurélio, em que se
discute a constitucionalidade da criminalização dos abortos de fetos anencéfalos,
caso o Tribunal decida pela procedência da ação, dando interpretação conforme
aos arts. 124 a 128 do Código Penal, invariavelmente proferirá uma típica
decisão manipulativa com eficácia aditiva. Ao rejeitar a questão de ordem levantada pelo Procurador-Geral da República, o Tribunal admitiu a possibilidade de, ao julgar o mérito da ADPF 54, atuar como verdadeiro legislador positivo, acrescentando mais uma excludente de ilicitude - no caso de o feto padecer de anencefalia - ao crime de aborto. Isso quer dizer que, pelo menos segundo o meu voto, está rechaçado o argumento da autora, de atipicidade do fato.

Acolho a hipótese de que a Corte criará, ao lado das já existentes (art. 128, I e II), uma nova hipótese de excludente de ilicitude do aborto.

Portanto, não se pode negar que o Supremo Tribunal Federal está a se livrar do vetusto dogma do legislador negativo e, nesse passo, alia-se à mais progressiva linha jurisprudencial das decisões interpretativas com eficácia aditiva, já adotadas pelas principais Cortes Constitucionais europeias. A assunção de uma atuação criativa pelo Tribunal poderá ser determinante para a solução de antigos problemas relacionados à inconstitucionalidade por omissão, que muitas vezes causa entraves para a efetivação de direitos e garantias fundamentais assegurados pelo texto constitucional.

(...)

Em verdade, é preciso deixar claro que a prolação de decisões interpretativas com efeitos aditivos não é algo novo na jurisprudência do STF. Poder-se-ia, inclusive, atestar que se trata apenas de uma nova nomenclatura, um novo (e

\footnotetext{
${ }^{180}$ Voto do Ministro Ricardo Lewandowski na ADPF n. 54/DF, pp. 8 e 14-15 (pp. 245 e 251-252 do acórdão) (realces originais).
} 
mais adequado) termo técnico para representar formas de decisão que o Tribunal costuma tomar quando realiza a conhecida interpretação conforme a Constituição e, com isso, acaba por alterar, ainda que minimamente, os sentidos normativos do texto legal. Tornou-se algo corriqueiro mencionar a jurisprudência da Corte italiana sobre o tema para, num exercício de direito comparado, defender a "introdução" de novas técnicas de decisão no controle abstrato no Brasil.

Conforme se verifica neste e em outros julgados recentes, o Supremo Tribunal Federal vem tomando um posicionamento mais proativo na defesa de direitos fundamentais, ainda que as matérias sob discussão envolvam grandes divergências. Conquanto não adote, sempre e necessariamente, posicionamento ativista, constata-se um novo escopo de atuação, que assume os riscos de ultrapassar os limites tradicionais da função jurisdicional, em um processo que necessariamente envolve o autorreconhecimento institucional de que a Corte pode adentrar no campo político sob a escusa de buscar tutelar e proteger direitos constitucionalizados.

A institucionalização de diversos instrumentos que permitem que o Supremo Tribunal Federal atue na seara normativa - e que por vezes podem ter seu escopo e efeitos ampliados em razão da própria interpretação da Corte a respeito desses mecanismos naturalmente causa um processo em que a Corte se vê paulatinamente mais legitimada a expandir seu papel frente ao processo de definição de políticas fundamentais. A inexistência de reação institucional incisiva por parte do Legislativo ou do Executivo, por sua vez, bem como a positiva receptividade social e midiática de decisões que tratam de definir a amplitude e a extensão de direitos fundamentais, incitam o Supremo Tribunal Federal a testar os limites de sua atuação junto aos demais Poderes e à própria sociedade. A Corte, em suma, passou por um processo de engajamento político, de modo que hoje se coloca como verdadeiro partícipe da definição do arcabouço jurídico nacional. ${ }^{181}$

\footnotetext{
${ }^{181}$ Consoante já antevia José Afonso da Silva: “a justiça constitucional brasileira deverá tomar novo rumo com a prática da Constituição de 1988, mormente tendo em vista que ela transformou o STF em seu guardião, reduzida sua competência à solução de conflitos de interesse composto por normas constitucionais - com o quê ele já se delineia como uma Corte Constitucional, algo diferente das Cortes europeias, mas com uma nova visão de sua missão constitucional e de sua função política." SILVA, José Afonso da, op. cit., p. 166.
} 


\subsection{A definição de políticas legislativas pelo Supremo Tribunal Federal}

Em complemento aos elementos apontados no capítulo anterior, mostra-se relevante analisar a evolução das matérias submetidas ao Supremo Tribunal Federal, bem como o posicionamento adotado em determinados casos emblemáticos. Conforme se buscará demonstrar, a intervenção do Supremo Tribunal Federal - assim como a de Cortes Constitucionais como um todo - segue num crescente em direção à maior participação política. Isso coaduna-se com a ideia de que a Corte passa a assumir um compromisso mais profundo, e a encampar uma posição mais efetiva na conformação do ordenamento jurídico, à medida que sua atuação e decisões passam a contar com respaldo e aceitação dos demais Poderes e da sociedade como um todo - que, ainda que critiquem muitas das decisões, acatam-nas dentro das premissas do jogo democrático.

\subsubsection{A natureza das questões políticas submetidas à Corte}

Já se afirmou, com base na lição de Martin Shapiro ${ }^{182}$, que o controle de constitucionalidade é criado, inicialmente, para lidar com problemas institucionais - em especial o federalismo, que também envolve a questão quanto a competências dos entes federados, e a separação de Poderes -, concluindo o autor que, como regra, questões relativas à proteção de direitos fundamentais passam a ocupar os trabalhos das Cortes Constitucionais apenas em um segundo momento, quando sua atuação já está mais sedimentada e quando o órgão entende-se mais confortável em se imiscuir em matérias que envolvam maior repercussão política e social.

A análise da evolução dos casos levados ao Supremo Tribunal Federal em sede de controle normativo permite constatar, com alguma segurança, que o Brasil não foge à regra esboçada por Shapiro. A despeito da infinidade de temas submetidos à Corte ao longo da década de 1990 e do primeiro quinquênio do século XXI, as ações que assumem maior relevância voltavam-se, sobretudo, a dirimir questões institucionais, i.e., ligadas aos parâmetros de atuação dos entes e órgãos estatais, à repartição e limites de competências

\footnotetext{
${ }^{182}$ SHAPIRO, Martin. "The Success of Judicial Review and Democracy”, in: SHAPIRO, Martin; STONE SWEET, Alec, op. cit., pp. 149 e ss.
} 
constitucionais, ao princípio da separação de Poderes e à estrutura e a regras aplicáveis ao nosso sistema político-partidário-eleitoral.

O fato de tais temas ocuparem, com maior representatividade, a agenda do Supremo Tribunal Federal pode ser melhor compreendido ao se considerar que se estava, ainda, em um período de sedimentação do novo regime democrático. É natural que, com a vigência de uma nova Constituição, em especial de uma que sucede um regime ditatorial, os atores políticos ainda não tenham clara dimensão a respeito das normas que emanam dos preceitos constitucionais no tocante às balizas que devem pautar a atividade estatal tanto dos entes federados quanto dos órgãos que compõem os três Poderes - e ao desenvolvimento do cenário político-eleitoral. O Supremo Tribunal Federal, em seu papel de guardião da Constituição, acaba por ser o órgão que participa da complementação do regramento constitucional e do estabelecimento dos limites e parâmetros do sistema, sedimentando as premissas do jogo democrático. Ainda quando assuma uma posição de autocontenção - conforme ocorreu, em grande parte, nesse período -, acaba inevitavelmente por desempenhar importante papel na definição de regras de suma importância à política nacional.

Nesse sentido, pode-se afirmar que, conquanto houvesse, nesse período inicial, casos relativos a direitos fundamentais dos indivíduos e da coletividade, essa temática não ocupava de forma expressiva a agenda da Corte. A apreciação de questões dessa natureza é sempre mais delicada, dado que o Supremo Tribunal Federal é instado não apenas a regulamentar conflitos entre entidades estatais e/ou de representatividade da soberania popular, mas verdadeiramente a definir o cerne e a extensão dos direitos que os indivíduos possuem perante o Estado - o que igualmente envolve a imposição de limites à atuação do legislador. Em ambos os casos, o Supremo Tribunal Federal pode chegar ao ponto de sobrepor sua ponderação do regramento constitucional àquela feita pelo legislador constitucional ou infraconstitucional. Não obstante, na seara dos direitos fundamentais, se está quase sempre diante de conflitos que envolvem maior repercussão social e midiática, com o que a - sempre possível - superação da escolha do legislador acarreta responsabilidades institucionais de maior peso.

Outro aspecto a ser mais uma vez destacado remete à política institucional do Supremo Tribunal Federal nesse período inicial, voltado muito mais à autocontenção que ao ativismo judicial. Trata-se de processo natural à evolução das atividades de Cortes Constitucionais, que tendem a exercer o controle normativo de maneira mais contida no 
período de consolidação de sua atividade, quando do surgimento de um novo paradigma constitucional ou quando da sedimentação de um novo modelo de controle de constitucionalidade. Um posicionamento voltado ao ativismo acaba por confluir com o período em que a Corte passa a ocupar-se, com maior frequência e de forma mais incisiva, da seara dos direitos fundamentais.

$\mathrm{Na}$ fase inicial de atuação do Supremo Tribunal Federal sob a vigência da Constituição de 1988 fica evidenciada maior deferência e respeito às escolhas feitas pelo legislador, evitando a Corte, a todo custo, substituir a decisão legislativa, a menos que houvesse clara e patente inconstitucionalidade. A Corte colocava-se, no mais das vezes, na estrita função de veto da atividade normativa. Não raras vezes, e conforme se verá, afirma em seus julgamentos a supremacia da opção legislativa, mesmo quando essa não pareça a melhor e a mais adequada dentre as opções disponíveis, reforçando que o Judiciário não é o local adequado para buscar o aperfeiçoamento da norma positivada.

Com o desenvolvimento da atividade da Corte, que se deu juntamente com a evolução jurisprudencial de seus instrumentos de controle de constitucionalidade - que paulatinamente dotaram-na de mais influência política -, verifica-se uma renovação em seu escopo de atuação. O Supremo Tribunal Federal passou a intervir com maior frequência como legislador positivo, assumindo o papel de corrigir eventuais distorções ou inconsistências do ordenamento. Esse processo se insere, também, em um contexto em que uma nova gama de questões passa a tomar maior relevância dentro de sua agenda, essencialmente voltada à proteção de direitos fundamentais e que naturalmente convida a Corte a adotar um papel político mais efetivo. O silêncio legislativo quanto a matérias sensíveis - que envolvem custos políticos e eleitorais à governabilidade e à manutenção de coalizões - passa a ser encarado pelo Supremo Tribunal Federal como um indicativo, dentro da premissa de que esse silêncio não pode permitir a ausência de tutela efetiva a direitos fundamentais, de que a cúpula do Judiciário nacional torna-se a seara adequada para a discussão e definição dessas questões. A ideia implícita de que haja uma deferência voluntária, dos agentes políticos ao Judiciário, quanto a matérias de grande repercussão - e que em parte explica a criação de sistemas de controle de constitucionalidade - faz com que o Supremo Tribunal Federal se sinta como verdadeiro responsável pela definição do núcleo dos direitos fundamentais e pela correção dos rumos da política nacional em temas altamente controvertidos. 
Tem-se como exemplo dessa nova agenda, por exemplo, a já mencionada ADPF n. 54/DF, a respeito do abortamento de fetos anencéfalos ${ }^{183}$, a questão da utilização de células-tronco embrionárias em pesquisas ${ }^{184}$ e o debate a respeito da união estável homoafetiva $^{185}$, em que o Supremo Tribunal Federal foi verdadeiro protagonista na definição do conteúdo e das implicações dos direitos fundamentais envolvidos.

Importante ainda ressaltar que essa nova temática não substituiu as matérias que tradicionalmente eram submetidas ao Supremo Tribunal Federal, mas, pelo contrário, somou-se a elas. Tem-se, com isso, uma agenda mais diversificada, que trata de temas tanto institucionais quanto ligados a direitos fundamentais. Não obstante, essa nova política do órgão acaba por refletir até mesmo na forma como a Corte encara aqueles debates mais tradicionais, a respeito da separação de Poderes, do federalismo e da conformação do nosso sistema político-eleitoral. Tem-se constatação disso já na redefinição, pelo Supremo Tribunal Federal, a respeito das premissas do nosso sistema político-partidário, pela qual introduziu regras quanto à fidelidade partidária não previstas pelo legislador, quer constituinte quer ordinário ${ }^{186}$. Do mesmo modo, mais recentemente, no julgamento da ação direta de inconstitucionalidade n. 4.650/DF, a respeito do financiamento de campanhas eleitorais por pessoas físicas e jurídicas, a Corte vem delineando diretriz que demonstra seu engajamento em sobrepor suas ponderações, a respeito da adequação do sistema político e das premissas que balizam a democracia, às escolhas do próprio legislador.

O Supremo Tribunal Federal tornou-se, em suma, o local de debate por excelência de questões políticas (revestidas no discurso jurídico) sensíveis à sociedade e ao Estado. Suas decisões acabam inevitavelmente por refletirem no campo político, na medida em que envolvem a revaloração judicial de escolhas legislativas. A proliferação e a diversidade de matérias submetidas a julgamento em sede de controle de normas mostram, por sua vez, que o Tribunal é visto como instância de contestação de políticas legislativas por grupos que não conseguem revertê-las no processo legiferante - por falta de acesso ou pela impossibilidade de conseguir a maioria necessária para tanto, por exemplo -, bem como de

\footnotetext{
${ }^{183}$ Relator Ministro Marco Aurélio Mello, j. em 12.04.2012.

${ }^{184}$ ADI n. 3.510/DF, relator Ministro Ayres Britto, j. em 29.05.2008.

${ }^{185}$ ADI n. 4.277/DF e ADPF n. 132/RJ, ambas de relatoria do Ministro Ayres Britto e j. em 05.05.2011.

${ }^{186}$ Conforme decisões proferidas nos mandados de segurança n. 26.602/DF, n. 26.603/DF e 26.604/DF, todos j. em 04.10.2007. Muito embora não se trate de julgamento em sede de controle abstrato de constitucionalidade, tem-se aí relevante caso da potencialidade do poder político do Supremo Tribunal Federal, que em verdade estipulou nova regra, não prevista na Constituição, quanto à perda do mandato parlamentar.
} 
complementação e/ou retificação de macropolíticas quando o Legislativo mostra-se inerte ou relutante a defini-las ou readequá-las às mudanças políticas, econômicas e sociais.

\subsubsection{Análise de casos relevantes}

Seguem abaixo retratados, de forma resumida, alguns casos julgados pelo Supremo Tribunal Federal que, somados aos demais já mencionados ao longo deste trabalho, permitem descortinar a evolução retratada quanto às matérias submetidas a julgamento pelo Supremo Tribunal Federal em sede de controle de constitucionalidade, bem como quanto à sua política institucional. Trata-se, por óbvio, de uma seleção limitada ante a infinidade de casos levados a julgamento perante a Corte, mesmo em sede de controle abstrato, mas que já permitem vislumbrar a relevância das matérias submetidas e a amplitude que assumem tais julgamentos.

Nas ações diretas de inconstitucionalidade (ADI) n. 829/DF ${ }^{187}$ e n. 833/DF ${ }^{188}$ questionava-se a constitucionalidade da emenda constitucional n. 2 de 1992, que tratava de antecipar o plebiscito previsto no artigo $2^{\circ}$ dos Atos de Disposições Constitucionais Transitórias (ADCT) e de remanejar a competência estabelecida em seu $\S 2^{\circ}$, que permitia ao Tribunal Superior Eleitoral regulamentar tal artigo. Arguia-se, em suma, tanto a incompetência do Poder Constituinte Derivado em alterar as disposições dos ADCT quanto suposta violação ao princípio da separação dos Poderes, ao se restringir a competência inicialmente atribuída ao Tribunal Superior Eleitoral.

O Supremo Tribunal Federal, ao julgar as ações improcedentes por maioria de votos, fixou e reafirmou importantes premissas quanto ao nosso sistema constitucional, a exemplo da competência da Corte em apreciar a constitucionalidade de emendas constitucionais, o status de normas constitucionais dos ADCT - e, portanto, passíveis de alteração por emenda constitucional -, bem como a interpretação que se deve dar à cláusula pétrea relativa ao princípio da separação dos Poderes, no sentido de que não são admitidas mudanças tendentes à abolição desse princípio, o que por sua vez não impede remanejamento de competências entre os órgãos estatais. Sobressai, nesse julgado, a posição do Supremo Tribunal Federal como partícipe da definição de premissas

\footnotetext{
${ }^{187}$ Relator Ministro Sepúlveda Pertence, j. em 14.04.1993.

${ }^{188}$ Relator Ministro Sepúlveda Pertence, j. em 14.04.1993.
} 
importantes quanto ao nosso sistema constitucional, bem como resta evidente um maior respeito à atuação do legislador e às suas escolhas na conformação do nosso ordenamento.

Na ADI-MC n. 839/DF ${ }^{189}$ impugnava-se a constitucionalidade da lei n. 8.624, de 1992, que regulamentava o plebiscito para definição de forma e sistema de governo - de acordo com a nova redação dada ao artigo $2^{\circ}$ dos ADCT pela emenda constitucional n. 2, de 1992. O objeto central da discussão gravitava em torno do artigo $4^{\circ}$ da lei que estabelecia a criação de três frentes parlamentares "às quais se vincularão entidades representativas da sociedade civil" para a defesa das três opções de escolhas disponíveis ao eleitorado (quais sejam, parlamentarismo com república, presidencialismo com república e parlamentarismo com monarquia), e do $\S 1^{\circ}$ de seu artigo $5^{\circ}$, que conferia exclusividade a essas frentes parlamentares na representação desses interesses e no gozo de espaços para propaganda de suas propostas.

As questões principais levantadas versavam a respeito do nosso sistema políticoeleitoral, que garantiria exclusividade de representação, quanto ao exercício da soberania popular, a partidos políticos devidamente registrados - estando fora desse processo, portanto, as frentes parlamentares aludidas na lei -, instituições essas que, no mais, pela redação da lei, ficariam impedidos, ou no mínimo prejudicados, de participar dos debates relativos ao plebiscito que se realizaria. Haveria, assim, violação a cláusula pétrea relativa a direitos e garantias fundamentais, conjunto normativo de que fariam parte disciplinas relativas a direitos políticos e partidos políticos. Pela temática da discussão, a Corte foi instada a se pronunciar sobre a configuração de nosso sistema de representação política, bem como a analisar a liberdade do legislador quanto à estipulação de regras aplicáveis ao referido plebiscito.

O julgamento da medida cautelar foi, por maioria, no sentido da inexistência de inconstitucionalidade, tendo os julgadores apresentado ponderações sobre nossa realidade pluripartidarista e entendido que a opção do legislador não afrontava quaisquer regras ou princípios constitucionais. Relevante destacar a divergência instaurada entre o Ministro relator, Néri da Silveira (que entendia pela supressão da eficácia do vocábulo "só" constante do $\S 1^{\circ}$ do artigo $5^{\circ}$ da lei impugnada, para que os partidos políticos também tivessem acesso aos espaços de propaganda) e o Ministro Paulo Brossard (que entendia pela total constitucionalidade da lei, apenas ressalvando que partidos que possuíssem definição clara quanto a sistema de governo em seus programas poderiam se filiar às

${ }^{189}$ Relator Ministro Néri da Silveira, j. em 17.02.1993. 
correspondentes frentes parlamentares - voto este que acabou contando com a concordância da maioria). Nesse debate, é aventado, expressamente, o emprego do instituto da interpretação conforme, dado que a exegese levantada pelo Ministro Paulo Brossard delimitava e explicitava em que sentido o termo "só" deveria ser compreendido i.e., no sentido de facultar que os partidos políticos integrassem as frentes parlamentares e gozassem de espaço de propaganda, o que deveria, entendeu-se, ser regulamentado pelo Tribunal Superior Eleitoral, consoante disposições do artigo $2^{\circ}$ dos ADCT - com alterações trazidas pela emenda constitucional n. 2 de 1992. Tem-se aqui uma das primeiras oportunidades em que a Corte pôde analisar o nosso sistema político-partidário, para daí extrair conclusões e premissas que permitam avaliar a constitucionalidade de normas positivadas.

No julgamento da ADI n. 486/DF ${ }^{190}$, questionava-se a emenda constitucional n. 3, de 1990, da Constituição do Estado do Espírito Santo, que por sua tornava seu processo de reforma mais rígido que aquele previsto na Constituição Federal - exigia-se aprovação por 4/5 (quatro quintos) dos membros da Assembleia Legislativa.

Em seu voto pela inconstitucionalidade da emenda impugnada, seguido pelos demais Ministros, o relator Ministro Celso de Mello teceu considerações a respeito dos limites do legislador constituinte decorrente em face dos parâmetros estabelecidos no Texto Magno. O Supremo Tribunal Federal, nesse caso, apresentou uma fundamentação que em verdade se projeta para além do caso sob análise, na medida em que discorre em tese sobre a própria liberdade de conformação política dos Estados federados, fixando entendimento de que estes estão sujeitos não apenas a diretrizes gerais estabelecidas na Constituição Federal, mas igualmente a regras específicas ligadas à própria rigidez constitucional. Reforçou-se, assim, a natureza subordinada do Poder Constituinte dos Estados federados, bem como a primazia de regras específicas estabelecidas na Lei Maior. Apenas em um segundo momento, e quando, portanto, já se reconhecia a inconstitucionalidade da emenda em razão de destoar das diretrizes da Constituição Federal, é que a Corte analisou especificamente as consequências das regras trazidas pela emenda questionada. Concluiu-se, nesse aspecto, pela existência de vício em razão de o quórum previsto dificultar sobremaneira - fala-se até mesmo em risco de esterilização e inviabilização - o exercício do Poder Constituinte Decorrente. Relevante apontar aqui o papel didático e prospectivo exercido pelo Supremo Tribunal Federal ao ditar premissas

${ }^{190}$ Relator Ministro Celso de Mello, j. em 3.4.1997. 
sob as quais podem atuar os legisladores estaduais, bem como ao fixar a imperatividade de normas trazidas pela Constituição Federal que, no entender da Corte, estejam ligadas à estabilidade política da nação. ${ }^{191}$

Na ADI-MC n. 1.805/DF ${ }^{192}$ visava-se a conferir interpretação conforme ao artigo 14, $\S 5^{\circ}$ da Constituição Federal, segundo redação dada pela emenda constitucional n. 16, de 1997 - que instituiu a reeleição para cargos do Executivo -, e à legislação eleitoral (lei n. 9504, de 1997), de modo que se estendesse a regra de desincompatibilização - aplicável caso o detentor de mandato eletivo junto ao Executivo almejasse candidatar-se a outro cargo $^{193}$ - para candidatos à reeleição para o mesmo cargo do Executivo. Não se questionava, em absoluto, a emenda constitucional que instituiu a reeleição, mas apenas pretendia-se equiparar e igualar as regras aplicáveis aos candidatos, sem o que, arguia-se, haveria violação a preceitos constitucionais sensíveis, como a isonomia e o pluripartidarismo, com reflexos prejudiciais às regras do jogo democrático.

Tem-se aqui um dos casos em que a Corte ainda mantinha um posicionamento de autocontenção, com maior deferência às escolhas do legislador quando estas não se mostrassem patentemente incompatíveis com a Constituição. Nesse sentido, a maioria que votou pela improcedência da medida cautelar entendeu que, muito embora pudesse haver aparente contradição na sistemática adotada pelo legislador, não havia ali qualquer regra que fugisse à razoabilidade, de modo que não caberia ao Supremo Tribunal Federal corrigir o texto normativo com base em meros juízos a respeito de qual teria sido a melhor escolha dentre as possíveis. Nota-se, com base nessa ratio decidendi, um posicionamento mais contido da Corte, com maior deferência e respeito às escolhas do legislador quando não haja evidente vício de inconstitucionalidade - e ainda que acarretem alguma incoerência normativa que, não obstante, não impeça a aplicação das regras positivadas. Cabe, quanto a isso, citar trecho do voto do Ministro relator, seguido pela maioria:

\footnotetext{
Se o constituinte derivado deveria ter incluído a cláusula de exigência de afastamento definitivo do titular, seis meses antes do pleito, tal como a matéria foi efetivamente discutida no Congresso Nacional, ou não, resultou isso de uma decisão política que não pode ser, aqui, confrontada, a ponto de alterar-se o conteúdo do preceito constitucional, por via de exegese da norma do art. $14, \S 5^{\circ}$,

${ }^{191}$ José Afonso da Silva aponta, inclusive, que o controle normativo sobre as Constituições Estaduais é tema recorrente na agenda do Supremo Tribunal Federal: "Com promulgação da atual Constituição e com a elaboração das Constituições Estaduais, novamente temos um grande volume de ações diretas de inconstitucionalidade de dispositivos das Cartas Estaduais." SILVA, José Afonso, op. cit., p. 154.

${ }^{192}$ Relator Ministro Néri da Silveira, j. em 26.03.1998.

${ }^{193} \mathrm{Cf}$. artigo 14, $\S 6^{\circ}$, da Constituição Federal.
} 
em vigor, da Lei Magna, a fim de, nele, introduzir exigência que o constituinte reformador não quis fazê-la. Se é difícil admitir, como sustentam os autores, que para concorrer ao mesmo cargo não há necessidade de renúncia, fazendo-se esta necessária quando o titular pretenda disputar cargo diverso (...), certo é que não cabe corrigir tal disposição em juízo de controle de constitucionalidade, onde a Corte desempenha função de legislador negativo e não de legislador positivo, para exigir, restringindo direitos, o que não foi estabelecido como condição pelo legislador constituinte, o qual optou, é exato, pela dispensa da cláusula do afastamento. (...) Se o sistema restou de difícil compreensão, não é quaestio juris que a Corte possa resolver. ${ }^{194}$

Em sentido diverso ao do caso precedente, o julgamento das ADI n. 1.351/DF ${ }^{195} \mathrm{e}$ ADI 1.354/DF ${ }^{196}$, versando sobre a cláusula de desempenho instituída pelo artigo 13 da lei n. 9.096, de 1995, mostra significativa mudança nas concepções da Corte a respeito dos limites de sua atuação quando instada a confrontar as escolhas do legislador. Em apertada síntese, o dispositivo impugnado limitava o funcionamento parlamentar e o acesso a verbas e a horários gratuitos de propaganda a partidos políticos que não atingissem patamares mínimos, fixados na lei, em votações nacionais para a Câmara dos Deputados. Questionava-se, assim, a validade da norma frente às premissas do pluripartidarismo nacional.

Trata-se de caso emblemático, dada sua relevância para o cenário político, pela mudança nos rumos do julgamento da Corte e o tempo levado para o julgamento de mérito da questão: ajuizadas em 1996, quando a Corte rejeitou pedido liminar (feito na ADI n. 1.354/DF) para suspensão do dispositivo atacado, entendendo que não havia inconstitucionalidade prima facie a embasar o deferimento da medida ${ }^{197}$, o julgamento de mérito sobreveio apenas em 2006. O lapso temporal em alguma medida é explicado pelo fato de as regras do artigo impugnado apenas terem vigência inicial programada para a legislatura que se iniciaria no ano de 2007, aplicando-se no período entre o início da legislatura subsequente à publicação da lei e aquela que se iniciaria em 2007 o regramento transitório de seu artigo 57.

Seja como for, é importante destacar que, num primeiro momento, o Supremo Tribunal Federal se via mais impelido a acatar as opções do legislador e as ponderações que faz quanto à conformação do regramento constitucional, segundo se depreende das

\footnotetext{
${ }^{194}$ Voto do Ministro Néri da Silveira na ADI n. 1.805/DF, p. 94.

${ }^{195}$ Relator Ministro Marco Aurélio, j. em 07.12.2006.

${ }^{196}$ Relator Ministro Marco Aurélio, ambas j. em 07.12.2006.

197 À época ainda sob relatoria do Min. Maurício Corrêa, o entendimento foi no sentido de que o artigo 17 , $\S 3^{\circ}$ da Constituição Federal permitia que a matéria sobre distribuição de fundos partidários e horários gratuito de propaganda fosse regulamentado por lei, que por sua vez não havia ultrapassado critérios de razoabilidade, ainda mais ao se levar em conta o - afirmava-se - pluripartidarismo exacerbado brasileiro.
} 
razões do mencionado indeferimento da medida cautelar pleiteada. No entanto, quando do julgamento de mérito, a Corte realizou verdadeira reanálise das premissas que, em seu entender, devem pautar a disputa político-partidária e as possibilidades de atuação dos partidos políticos, sobrepondo-se às valorações previamente feitas no Legislativo.

A ratio decidendi pautou-se, grosso modo, no entendimento de que seria inconstitucional a criação de classes diversas de partidos, uma das quais com mais prerrogativas que as outras, dado que isso permitiria um fortalecimento desmedido de partidos mais representativos e um verdadeiro sufocamento das minorias. Considerando que não se estava diante de verdadeira cláusula de barreira - no sentido de impedir que o partido que não atingisse patamares mínimos tivesse direito a assentos no Congresso Nacional -, mas sim de estabelecer tratamento diferenciado para partidos minoritários, haveria prejuízo ao imperativo de igualdade de chances na disputa política, razão pela qual a escolha legislativa chocava-se com os preceitos do sistema democrático nacional. Devese ainda pontuar que, ao longo da sessão de julgamento, houve uma série de debates em que os Ministros discutiam a forma mais adequada de se declarar as inconstitucionalidades almejadas, tendo em vista a necessidade de se manter a higidez e a coerência normativa da lei n. 9.096. Os autores das ADI pleiteavam a inconstitucionalidade do artigo 13 da lei e de todas as remissões feitas a este dispositivo nos demais artigos. Entendendo que isso traria um vácuo normativo e, em alguns pontos, verdadeira desinteligência dos dispositivos, o Supremo Tribunal Federal, ao declarar a inconstitucionalidade do dispositivo principalmente atacado, atingindo também algumas das demais referências feitas ao longo da lei, suprimiu a limitação temporal prevista no referido artigo 57, que tratava de disposição transitória, de modo que seu regramento vigesse até que sobreviesse nova legislação sobre a matéria.

Nota-se, nessa discussão, o Supremo Tribunal Federal assumindo a função de aperfeiçoar o sistema político nacional com base em suas próprias valorações sobre adequação normativa, em desprestígio à opção do legislador - que, consoante os votos na medida cautelar já citada, não padecia de clara e inconteste inconstitucionalidade - e de tutelar mais fortemente a proteção de interesses de minorias. Para tanto, entendeu razoável atuar como verdadeiro legislador positivo ao estabelecer a vigência de regras transitórias para além do estipulado em lei. A mudança na concepção da Corte desde a propositura das ações até o julgamento definitivo de mérito denota a evolução da política institucional de que já se tratou, o que também é em parte explicado pela completa renovação de sua 
composição nesse período - dos Ministros que a integravam em 1996, apenas três lá permaneciam quando da decisão de mérito em 2006.

Outro caso que se pode mencionar e que destaca a relevância das decisões da Corte em questões institucionais remete à discussão da fidelidade partidária. Muito embora não tenha sido objeto de decisão em sede abstrata de controle de constitucionalidade, acabou por representar uma nova conformação ao nosso regramento constitucional aplicável aos partidos políticos e aos candidatos eleitos pelo sistema proporcional.

Conforme bem anota Elival da Silva Ramos ${ }^{198}$, a problemática iniciou-se após uma consulta feita pelo Partido da Frente Liberal ao Tribunal Superior Eleitoral, que por sua vez, superando entendimento sedimentado na jurisprudência do Supremo Tribunal Federal, entendeu que os partidos e as coligações conservam o direito à vaga do parlamentar que solicitar sua desfiliação. Já se antevia, naquela decisão do órgão da Justiça Eleitoral, a necessidade de se estabelecerem exceções à regra a que se chegava, em especial para garantir a possibilidade de troca de partido - mantendo o parlamentar sua vaga - em casos de perseguição partidária ou de mudança ideológica do partido ou da coligação. Com base nessa decisão, foram interpostos, junto ao Supremo Tribunal Federal, três mandados de segurança ${ }^{199}$ contra decisões do Presidente da Câmara dos Deputados que negavam solicitações de que fossem convocados os suplentes para preencherem as vagas de deputados que haviam trocado de partido.

No julgamento dos writs, o Supremo Tribunal Federal modificou a jurisprudência que vinha até então seguindo, tendo inclusive fixado um termo inicial para a "vigência" do novo entendimento, de modo a evitar insegurança quanto à aplicação da nova regra que se criava. Dos votos proferidos verifica-se uma forte inclinação da Corte a realizar reparos em nosso sistema político-partidário, mesmo que isso acarretasse dar novos contornos não previstos no regramento constitucional. Não por acaso, a nova exegese firmada pauta-se, sobretudo, em valorações principiológicas a respeito de nosso sistema eleitoral proporcional e no papel desempenhado pelos partidos políticos em nossa democracia e no sistema representativo, com o que o Supremo Tribunal Federal acabou por impor a sua visão sobre que regras deveriam decorrer dos princípios que informam nosso sistema, o que traz em si: (i) um juízo implícito a respeito da adequação e da retidão das escolhas

\footnotetext{
${ }^{198}$ RAMOS, Elival da Silva. Ativismo judicial: parâmetros dogmáticos, op. cit., pp. 245 e ss.

${ }^{199}$ Mandados de segurança ns. 26.602/DF, 26.603/DF e 26.604/DF, todos j. em 04.10.2007.
} 
feitas pelo legislador e (ii) a assunção de um papel de instância de correção de supostas inconsistências do ordenamento.

A decisão que prevaleceu, ao fim e ao cabo, reescreveu o artigo 55 da Constituição Federal, fazendo ali inserir nova hipótese de perda de mandato parlamentar. Muito embora ligado a casos concretos, o julgamento acabou por produzir efeito generalizado, na medida em que ensejou a edição de resolução pelo Tribunal Superior Eleitoral ${ }^{200}$ para regulamentar a perda de mandato parlamentar em hipóteses que configurassem a denominada infidelidade partidária - estipulando inclusive exceções que justificam a troca de partidos. Tem-se, aqui, patente caso de ativismo judicial. ${ }^{201}$

Ademais, conforme já se mencionou, o Supremo Tribunal Federal passou a abrigar discussões que vão além de meras disputas institucionais, abrangendo também a seara dos direitos fundamentais e da definição do cerne dos direitos e prerrogativas constitucionalizados. Para além da ADPF n. 54/DF, já retratada, outros dois casos permitem constatar essa evolução na agenda política da Corte.

$\mathrm{O}$ primeiro deles remete à $\mathrm{ADI}$ n. $3510 / \mathrm{DF}^{202}$, em que se impugnava a constitucionalidade do artigo $5^{\circ}$ da lei n. 11.105, de 2005, conhecida como Lei de Biossegurança, que a seu turno autorizava pesquisas com células-tronco embrionárias sob certas condições elencadas na própria lei. Ajuizada pela Procuradoria-Geral da República, arguia-se, em síntese, que o embrião formado in vitro já encerrava uma vida que contava com proteção constitucional, de modo que não poderia ser utilizado em pesquisas científicas.

O caso teve ampla repercussão política, social e midiática, dado que envolvia discussões que ultrapassavam os limites jurídicos e adentravam os campos religioso, moral e filosófico. Não por acaso, o Ministro relator, Ayres Britto, admitiu diversas entidades na qualidade de amicus curiae e determinou a realização de audiência pública para ensejar o

\footnotetext{
${ }^{200}$ Resolução n. 26.610 do Tribunal Superior Eleitoral, de 2007.

${ }^{201}$ Segundo pondera Elival da Silva Ramos, a "perda de mandato não apenas por desfiliação do partido de origem, mas também por expulsão em casos de infidelidade partidária, deve ser item obrigatório de uma agenda consiste de reforma política, mas não pode prescindir da intervenção do Poder Constituinte de revisão, a quem compete disciplinar as hipóteses de perda de mandato, e do legislador ordinário, a quem cabe regular as competências decisórias e o procedimento aplicável. O uso retórico de expressões como 'o mandato pertence ao partido' não atenua a complexidade da matéria, necessitada de regulação envolvendo diversas decisões de conveniência e oportunidade político-institucional, mesmo porque, rigorosamente, na disciplina imposta pela atual Constituição, o mandato é de titularidade do parlamentar eleito (...). Podem-se entender as razões que levaram o Supremo Tribunal Federal a esse exercício candente de ativismo judicial, porém não justificar tal conduta à luz dessas razões." RAMOS, Elival da Silva. Ativismo judicial: parâmetros dogmáticos, op. cit., pp. 254-255.

${ }^{202}$ Relator Ministro Ayres Britto, j. 29.05.2008.
} 
debate da matéria junto a grupos que pudessem apresentar elementos relevantes para o convencimento da Corte. Ademais, considerando que o tratamento jurídico dado pelas posições divergentes passava pela definição do momento inicial da vida humana, que carece de solução normativa no Direito brasileiro, entendia-se que o Supremo Tribunal havia sido instado a decidir também esse ponto. A esse respeito, a Ministra Ellen Gracie, em seu voto, afirmou expressamente que não cabia à Corte essa função:

\begin{abstract}
Buscaram-se, neste Tribunal, a meu ver, respostas que nem mesmo os constituintes originários e reformador propuseram-se a dar. Não há, por certo, uma definição constitucional do momento inicial da vida humana e não é papel desta Suprema Corte estabelecer conceitos que já não estejam explícita ou implicitamente plasmados na Constituição Federal. Não somos uma Academia de Ciências. A introdução no ordenamento jurídico pátrio de qualquer dos vários marcos propostos pela Ciência deverá ser um exclusivo exercício de opção legislativa, passível, obviamente, de controle quanto a sua conformidade com a Carta de $1998 .^{203}$
\end{abstract}

O voto do Ministro relator, seguido pela maioria julgadora - incluída aí a própria Ministra Ellen Gracie -, não adentrou nessa definição. Pelo contrário, pautou-se em definir qual vida é objeto de tutela constitucional. A maioria julgadora entendeu, a esse respeito, que a Constituição protege e garante, em um primeiro momento, direitos e prerrogativas à pessoa já nascida, e, excepcionalmente à vida intrauterina, ao nascituro - ainda que, conforme apontou o relator, essa proteção admita ressalvas, como no caso de abortamentos permitidos. Entendeu-se, assim, que falta ao embrião extrauterino a condição de desenvolvimento no sentido de se tornar uma pessoa natural apta a ser sujeito da proteção almejada pelo Texto Magno. O foco, portanto, residiu menos na definição no momento inicial da vida ${ }^{204}$, e mais na definição do momento inicial da tutela normativa do indivíduo, que, em última análise, se daria com a nidação.

Entendeu-se, ainda, que as condicionantes normativas à utilização dos embriões produzidos in vitro permitiam constatar que eles não teriam qualquer viabilidade ou expectativa de desenvolverem a pluripotencialidade humana, ou porque deveriam ser inviáveis cientificamente falando, ou porque deveriam ser embriões excedentes de

\footnotetext{
${ }^{203}$ Voto da Ministra Ellen Gracie na ADI n. 3.510/DF, p. 1 (p. 214 do acórdão).

${ }^{204}$ Há que se ressalvar, v.g., o voto do Ministro Menezes Direito, que firmou posicionamento expresso no sentido de que o embrião extrauterino consubstancia vida digna de proteção constitucional, razão pela qual declarou inconstitucionalidade sem redução de texto de dispositivos na lei impugnada, em especial para que se desse entendimento pela impossibilidade de que, pelas pesquisas, fossem destruídos embriões produzidos in vitro que possuíssem viabilidade reprodutiva. Em sentido semelhante, pela declaração parcial de inconstitucionalidade sem redução de texto, o voto do Ministro Ricardo Lewandoswki.
} 
procedimentos de reprodução assistida. Em vista disso, inexistiria qualquer violação ao que a Constituição visa a proteger. Ademais, argumentou-se que as pesquisas impulsionadas pela lei impugnada se coadunariam com outros valores constitucionais, como o do desenvolvimento científico, o planejamento familiar, e mesmo a proteção de outras vidas de pessoas já nascidas - que seriam beneficiadas pelo progresso científico na área.

Embora tenha havido a manutenção da opção normativa do legislador, o julgamento dessa ação permite vislumbrar um Supremo Tribunal Federal comprometido e confortável em atuar na definição de questões sensíveis à sociedade, mesmo quando envolvam temas e problemas estranhos à ciência jurídica. Conquanto a definição do momento inicial da vida não tenha se tornado ponto central da decisão da maioria julgadora, a Corte acabou por definir em que momento a tutela constitucional passa a incidir no processo reprodutivo humano, o que por sua vez representa uma escolha de suma relevância em termos de política legislativa. Cabe ainda registrar que outros Ministros que também votaram pela improcedência da ADI propunham uma intervenção mais ativista da Corte, a exemplo dos Ministros Eros Grau e Gilmar Mendes, em especial pela tentativa de adicionar instrumentos de controle de pesquisas não previstos na lei impugnada: cogitou-se, a esse respeito, a submissão das pesquisas à fiscalização de órgão vinculado ao Ministério da Saúde. ${ }^{205}$

O segundo caso refere-se ao debate a respeito da união estável homoafetiva, tratada na ADPF n. 132/RJ ${ }^{206}$ e na ADI n. 4.277/DF 207 (a primeira, prejudicada em parte no que visava a conferir interpretação conforme a Decreto-Lei do Estado do Rio de Janeiro, em razão de se entender que a questão já havia sido superada por legislação estadual superveniente - e convertida em ADI, julgada em conjunto com a segunda).

Buscava-se atribuir interpretação conforme a Constituição ao artigo 1.723 do Código Civil, de modo a reconhecer a possibilidade de união estável entre pessoas do mesmo sexo. A repercussão do caso colocou o Supremo Tribunal Federal, novamente, sob os olhos da mídia e da sociedade como um todo, e os Ministros, ao longo das votações, demonstraram estar cientes da importância daquele julgamento e do papel que viriam a

\footnotetext{
205 E, na mesma linha proposta pelo Ministro Menezes Direito, outros Ministros votaram impondo condicionantes aditivas à lei, tanto de caráter fiscalizatório quanto relativos à própria utilização dos embriões - variaram, nesse sentido, entre a declaração de inconstitucionalidade sem redução de texto, a exemplo dos Ministros Menezes Direito e Ricardo Lewandowski, e a declaração de constitucionalidade mediante interpretação conforme com efeitos aditivos, a exemplo dos Ministros Eros Grau e Gilmar Mendes.

${ }^{206}$ Relator Ministro Ayres Britto, j. em 05.05.2011.

${ }^{207}$ Relator Ministro Ayres Britto, j. em 05.05.2011.
} 
desempenhar com a resolução da questão. Os debates que tomaram lugar ao longo dos votos refletem um Supremo Tribunal Federal já acostumado e confortável com a eventual "necessidade" de atuar como legislador positivo, entendendo isso como um efeito natural dos instrumentos de controle que possui e como um imperativo frente às omissões legislativas, o que aponta a uma política institucional mais propensa ao ativismo judicial. Nesse sentido, as palavras do Ministro Gilmar Mendes:

\begin{abstract}
Não há nenhuma dúvida de que aqui o Tribunal está assumindo um papel ativo, ainda que provisoriamente, pois se espera que o legislador autêntico venha a atuar. Mas é inequívoco que o Tribunal está dando uma resposta de caráter positivo.

Na verdade, essa afirmação - eu já tive oportunidade de destacar - tem de ser realmente relativizada diante de pretensões que envolvem a produção de norma ou a produção de um mecanismo de proteção. Deve haver aí uma resposta de caráter positivo. E se o sistema jurídico, de alguma forma, falha na composição desta resposta aos cidadãos, e se o Poder Judiciário é chamado, de alguma forma, a substituir o próprio sistema político nessa inação, óbvio que a resposta só poderá ser de caráter positivo. ${ }^{208}$
\end{abstract}

Mais que isso, o julgamento também demonstra um anseio de promover a proteção de minorias que não encontram respaldo nos meios ordinários de produção legiferante - e mesmo que isso represente uma atuação substitutiva da Corte -, o que pode ser constatado pela votação unânime no sentido do reconhecimento da união estável homoafetiva em nosso sistema jurídico, ressalvadas algumas divergências quanto à ratio decidendi. Novamente, transcreve-se passagem do Ministro Gilmar Mendes:

Ainda em relação a esse diálogo institucional entre os Poderes, é
interessante ressaltar mais uma vez os dilemas que marcam a atuação da
jurisdição constitucional. Por vezes, afirma-se que o Supremo Tribunal Federal
está exorbitando de suas funções, e alega-se, então, que nós estamos a interferir
em demasia na disciplina do sistema político. (...)
Contudo, no presente julgamento, nós temos outra singularidade: há um tipo de
inércia legislativa relacionada a um dever de proteção de direitos fundamentais
básicos, de direitos de minoria. Isso reivindica, então, a atuação da Corte. E me
parece que a pretensão está formulada de maneira correta. Seria muito fácil
responder que essa matéria deveria ser regulada por norma a ser editada pelo
Congresso Nacional como única condição possível. (...)
Neste caso, isto me parece muito claro, estamos a tratar de proteção dos
direitos fundamentais. Sabemos - e isso foi dito de forma muito clara a
partir de algumas sustentações da tribuna e também foi destacado no voto
do Ministro Relator - que a falta de um modelo institucional que proteja
essa relação estimula e incentiva o quadro de discriminação.
Então, é dever de proteção do Estado e, ultima ratio, é dever da Corte
Constitucional e da jurisdição constitucional dar essa proteção se, de
alguma forma, ela não foi engendrada ou concebida pelo órgão competente.
Parece-me, conclusivamente, que não há exorbitância de nossa parte

${ }^{208}$ Voto do Ministro Gilmar Mendes na ADI n. 4.277, p. 17 (p. 767 do acórdão). 
quando dizemos que a Corte está sendo chamada para decidir um caso que diz respeito aos direitos fundamentais e, no caso específico, de forma inequívoca, diz respeito a direitos de minoria. ${ }^{209}$

$\mathrm{O}$ voto do Ministro relator, Ayres Britto, guiou a maioria. Conferiu-se interpretação conforme a Constituição ao referido dispositivo do Código Civil, de modo a extirpar qualquer interpretação de seu enunciado que levasse à impossibilidade de reconhecimento daquele instituto entre pessoas do mesmo sexo. Fundamentou-se, em síntese, na ideia da igualdade tutelada pela Constituição e no entendimento de que os dispositivos do artigo 226 do Texto Magno não se prestavam a fazer qualquer diferenciação ou a criar espécies diferentes de famílias ou entidades familiares. Com isso, a referência expressa ao reconhecimento de união estável entre homem e mulher como entidade familiar, em seu $\S 3^{\circ}$, teria apenas caráter enunciativo, sem criar qualquer óbice ao reconhecimento de união estável homoafetiva e à atribuição de status de entidade familiar ou de família a essa realidade, com todos os efeitos jurídicos daí decorrentes, conforme a legislação infraconstitucional aplicável.

A divergência instalada recaía menos sobre os efeitos da decisão, e mais sobre os instrumentos empregados pelo Supremo Tribunal Federal para chegar à conclusão almejada. Nesse sentido, o Ministro Ricardo Lewandowski entendeu inaplicável a interpretação conforme, dado que o enunciado do $\$ 3^{\circ}$ do artigo 226 da Constituição Federal seria taxativo quanto à união estável entre pessoas de gêneros distintos, dado que a matéria teria sido inclusive debatida pela Assembleia Constituinte, optando-se pela expressa referência à entidade formada por homem e mulher. Não obstante, entendeu que a Constituição não dava guarida a práticas discriminatórias, e que a união entre pessoas de mesmo sexo era um dado novo da realidade que merecia tutela jurídica, aplicando-se-lhe, portanto, por interpretação analógica, e ante a inexistência de regramento legal específico, as regras relativas à união estável heteroafetiva.

O Ministro Gilmar Mendes também demonstrou preocupação com a utilização da técnica da interpretação conforme, em especial pelo fato de a norma impugnada do Código Civil ser reprodução do texto constitucional. Em vista disso, o Ministro entendia que a aplicação da interpretação conforme deveria ser, in casu, muito bem delimitada, sob pena de expor a Corte a um decisionismo exacerbado que atribui qualquer significado aos enunciados constitucionais e infraconstitucionais. Divergiu, assim, do relator quanto ao

\footnotetext{
${ }^{209}$ Voto do Ministro Ricardo Lewandowski na ADI n. 4.277, pp. 53-55 (pp. 803-805 do acórdão) (realces originais).
} 
entendimento de que não haveria lacuna legislativa, sendo suficiente a fixação da interpretação adequada aos textos normativos. Pelo contrário, entendeu que havia uma incompletude no sistema quanto a esse dado da realidade - a união entre pessoas do mesmo sexo -, defendendo que caberia à Corte determinar um regramento de aplicação provisória - a mesma aplicável a uniões estáveis heteroafetivas - até que sobreviesse legislação específica a respeito. Segundo ponderou, a pura e simples equiparação das uniões estáveis poderia ensejar indagações que extrapolariam os limites das possibilidades da Corte, a exemplo de questões a respeito de filiação e da conversão da união estável em casamento. Desse modo, reconheceu aplicável a interpretação conforme de maneira bastante restrita, apenas ao se considerar que o artigo 1.723 do Código Civil estaria sendo utilizado para impedir o reconhecimento de união estável homoafetiva, que, por sua vez, muito embora não possuísse guarida no artigo 226 da Constituição Federal, teria respaldo em nosso regramento constitucional com base em direitos de minoria, de igualdade e do livre desenvolvimento da personalidade do indivíduo.

Conforme se buscou demonstrar, há uma sensível mudança na forma pela qual o Supremo Tribunal Federal desempenha sua função de controle de constitucionalidade. Se antes havia uma tendência à autocontenção e uma análise mais centrada e concisa dos elementos normativos em jogo, a jurisprudência mais recente mostra uma Corte verdadeiramente inserida no contexto político e desejosa de participar da construção e da conformação das regras do ordenamento, ainda mais quando vislumbre omissões legislativas que tolham ou limitem direitos que os Ministros entendam fundamentais. Verifica-se, igualmente, uma tendência de extensão da ratio decidendi a elementos normativos com baixa densidade e alta carga polissêmica, com o que se verifica que a Corte tem tomado decisões que muitas vezes não decorrem do estrito cotejo de regras constitucionais positivadas, mas que se pautam em regras e corolários (não claramente positivados) que a própria Corte extrai, ao longo do processo hermenêutico-decisório, de princípios constitucionais que admitem larga valoração normativa.

Constata-se, assim, uma atuação jurisdicional verdadeiramente substitutiva que se firma na ponderação de premissas constitucionais do sistema, como se competisse ao próprio Supremo Tribunal Federal estabelecer as regras que delas deveriam decorrer. Foi assim no caso da instituição da fidelidade partidária, conclui Elival da Silva Ramos, em que a Corte se pautou em extrair regras a partir de princípios constitucionais pouco 
objetivados, a exemplo do princípio da representação proporcional. ${ }^{210} \mathrm{O}$ mesmo se diga quanto ao julgamento em curso do financiamento de campanhas eleitorais, conforme aponta José Levi Mello do Amaral Júnior em recente artigo intitulado, justamente, "Inconstitucionalidade sem parâmetro no Supremo". Afirma o autor que:

os votos proferidos manejaram, como parâmetros de controle, princípios constitucionais bastante amplos, como o republicano, o democrático, o da separação dos poderes, o da liberdade de expressão e, em especial, o da igualdade.

(...)

Ora, não há dúvida: o princípio republicano é essencial à Constituição de 1988 e, por isso mesmo, é indisponível ao legislador. Porém, dele não deriva um determinado modelo de financiamento de campanhas eleitorais. Tanto isso é verdade que o constituinte não se ocupou do assunto de modo explícito e detido. $^{211}$

O Supremo Tribunal Federal vem se tornando, assim, copartícipe da definição das premissas constitucionais do ordenamento, com o que avoca para si a função de definir as balizas e condicionantes de atuação dos demais Poderes, em especial quanto à escolha de políticas de relevância nacional.

\footnotetext{
${ }^{210}$ RAMOS, Elival da Silva. Ativismo judicial: parâmetros dogmáticos, op. cit.,

${ }^{211}$ AMARAL JÚNIOR, José Levi Mello do. "Inconstitucionalidade sem parâmetro no Supremo", disponível em: $\quad$ http://www.conjur.com.br/2013-dez-29/analise-constitucional-inconstitucionalidade-parametro-

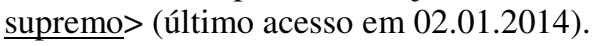




\section{EFEITOS SISTÊMICOS DA ATUAÇÃO POLÍTICA DO SUPREMO TRIBUNAL FEDERAL}

Os elementos apresentados nos capítulos precedentes dão conta de que o Supremo Tribunal desempenha, em ritmo crescente desde a redemocratização, relevante papel na definição de políticas fundamentais nacionais mediante controle do sistema normativoconstitucional.

O exercício do controle de constitucionalidade e das competências normativas da Corte, nos moldes apontados, assume, assim, uma função importante na conformação do ordenamento jurídico e das premissas que pautam o exercício das atividades típicas dos demais Poderes. Ainda que a participação do Supremo Tribunal Federal se dê dentro de parâmetros e do discurso próprios à ciência do Direito, acaba por englobar uma natureza política na medida em que reflete na liberdade de escolha e de ponderação valorativa dos demais atores políticos.

Há, nesse sentido, para além de um efeito imediato, que se projeta diretamente para as normas objeto de controle de constitucionalidade - e para a política legislativa subjacente -, um efeito medito relativamente às consequências que a interferência judicial acarreta na relação entre o Judiciário e os demais Poderes, ao papel que compete ao primeiro no resguardo dos compromissos democráticos e mesmo à própria construção e evolução do regramento constitucional pátrio. Fala-se aqui em efeitos sistêmicos da atuação política do Supremo Tribunal Federal, referindo-se àqueles que se propagam para além dos estritos limites dos processos constitucionais de controle normativo, mas como resultado destes.

\subsection{Executivo e Legislativo no contexto da expansão do Supremo Tribunal Federal}

Conforme já se afirmou anteriormente, a manutenção de um sistema de controle normativo ou mesmo de sua extensão depende, em alguma medida, da complacência dos demais Poderes, que detêm, em última análise, competência para realizar mudanças estruturais que podem tolher ou diminuir os instrumentos de controle do Judiciário. Com isso, integram a compreensão da expansão política do Judiciário - e, no presente caso, do 
Supremo Tribunal Federal -, alguns apontamentos sobre a reação dos demais atores políticos e sobre a forma como se desenvolve a interação interinstitucional entre os Poderes em torno da influência política exercida atualmente pela Corte.

\subsubsection{A reação dos demais Poderes à interferência política do Supremo Tribunal Federal}

Existe uma tendência de se buscar atribuir efeito vinculante e eficácia erga omnes às decisões do Supremo Tribunal Federal que repercutam em questões políticas quando estejam atreladas ao controle de constitucionalidade (em regra, abstrato) ou mesmo ligadas a alguma competência normativa da Corte.

Inicialmente, o artigo 102, §2 ${ }^{\circ}$, da Constituição Federal (conforme inclusão decorrente da Emenda Constitucional n. 3, de 1993), apenas estipulava "eficácia contra todos e efeito vinculante" em decisões proferidas em ações declaratórias de constitucionalidade. A Emenda Constitucional n. 45, de 2004, por sua vez, estendeu tais propriedades para as decisões prolatadas em sede de ação direta de inconstitucionalidade, justamente o campo em que a atuação do Supremo Tribunal Federal enseja maior reflexo político - o que por sua vez reafirmou determinação já dada pelo legislador infraconstitucional na regulamentação dessa ação pela lei n. 9.868, de 1999, que inclusive em seu artigo 28, par. ún., vai além e expressamente atribui efeitos vinculantes e eficácia erga omnes à decisão que atribui interpretação conforme a Constituição ou que declara inconstitucionalidade parcial sem redução de texto. Quanto às decisões proferidas em arguições de descumprimento de preceito fundamental, a eficácia erga omnes e a vinculatividade decorrem da regulamentação trazida pela lei 9.882, de 1999 (cf. artigo 10, $\left.\S 3^{\circ}\right)^{212}$

A tendência é ainda verificada na própria interpretação que a Corte faz dos institutos de controle normativo, a exemplo da recente jurisprudência quanto aos efeitos e às possibilidades de atuação do Supremo Tribunal Federal em julgamentos de mandados de injunção, e da discussão sobre a mutação constitucional que se busca fazer reconhecer

\footnotetext{
${ }^{212}$ Conforme já mencionado anteriormente, há críticas na doutrina quanto à previsão de tais efeitos em sede infraconstitucional. Nesse sentido, ver: FERREIRA FILHO, Manoel Gonçalves. "O sistema constitucional brasileiro e as recentes inovações no controle de constitucionalidade (leis $\mathrm{n}^{\circ} 9.868$, de 10 de novembro e $\mathrm{n}^{\circ}$ 9.882, de 3 de dezembro de 1999)", op. cit., pp. 12 e 14-15.
} 
na reclamação n. 4.335/AC - que acarretaria verdadeira reestruturação ao sistema concreto de controle normativo brasileiro.

Por fim, pode-se ainda mencionar as súmulas vinculantes, que, conquanto não integrem estritamente o rol de instrumentos de controle de constitucionalidade, permitem que a Corte, para além de estender os efeitos de declarações de inconstitucionalidade proferidas em controle difuso, interfira na composição das regras do ordenamento jurídico pátrio mediante fixação de interpretações que são vinculantes aos demais órgãos do Judiciário e à Administração Pública.

Para que se analisem tais efeitos do ponto de vista interinstitucional - e, portanto, deixando de lado as consequências à própria atuação dos demais órgãos judiciais -, devese ter em mente que a vinculatividade e a ampla eficácia de que se fala abrangem, em tese, apenas o Executivo, ou melhor, a Administração Pública - direta e indireta, de todas as esferas da Federação. Ao menos, é assim que tais atributos vêm sendo tratados tanto no âmbito da Constituição - no tocante aos efeitos das súmulas vinculantes e das decisões em ações declaratórias de constitucionalidade e em ações diretas de inconstitucionalidade - e no âmbito infraconstitucional - com a excepcionalidade de que na lei n. 9.882, de 1999, que regulamenta a arguição de descumprimento de preceito fundamental, o $\S 3^{\circ}$ de seu artigo 10 fala em vinculação relativamente "aos demais órgãos do Poder Público" indiscriminadamente. Quanto ao controle das omissões normativas, e caso o próprio Supremo Tribunal Federal não venha a superá-las por decisão de efeitos aditivo e substitutivo - ainda que a título precário e posteriormente alterável por ato normativo próprio da instância política competente - entende-se, igualmente, que apenas o Executivo pode ser condenado a suprir o vácuo ou a lacuna normativa dentro de prazo fixado pela Corte, consoante inteligência que se extrai do $\S 2^{\circ}$ do artigo 103 da Constituição Federal de 1988 (conforme já apontado no item 2.1.2 supra).

Em vista disso, pode-se afirmar que, no plano interinstitucional, a atuação política do Supremo Tribunal Federal condiciona, de forma mais imediata, a atividade do Poder Executivo, que, por força da própria Constituição, deve observância a uma série de decisões proferidas. $\mathrm{O}$ ordenamento não prevê de maneira expressa qualquer saída ou mecanismo de que o Executivo possa lançar mão no intuito de negar cumprimento àquilo que for decidido, quer se esteja diante da fixação de uma interpretação - via súmula vinculante ou interpretação conforme -, quer de declaração de constitucionalidade ou de 
inconstitucionalidade em via abstrata - neste último caso, em todas as suas modalidades e possibilidades.

Essa discussão, entretanto, passa pela compreensão das alterações constitucionais e infraconstitucionais que estenderam os efeitos e a vinculatividade das decisões do Supremo Tribunal Federal. Conforme leciona Roger Stiefelmann Leal, antes da Emenda Constitucional n. 45, de 2004, e quando ainda apenas se atribuía ampla eficácia e efeitos vinculantes - no plano constitucional, frise-se - às decisões prolatadas em ação declaratória de constitucionalidade, fazia-se expressa referência ao Poder Executivo. ${ }^{213} \mathrm{O}$ critério empregado era, assim, orgânico. Atualmente, nos diversos institutos acima referidos, fala-se, pelo contrário, em vinculação da Administração Pública, o que pode levar à conclusão de que, muito embora a Presidência da República (assim como os cargos correspondentes nas outras esferas federativas) integre a administração direta, a observância aos ditames das decisões da Corte incide apenas no tocante ao exercício da função administrativa. ${ }^{214}$ Ademais, deve ser considerado que a constrição da atuação do Executivo pelo Supremo Tribunal Federal, que numa análise literal das regras aplicável já ocorre em patamar sensível, será tanto maior quanto mais elasticidade se atribua ao próprio objeto da vinculação.

De todo modo, e embora atos do Executivo que estejam fora do estrito âmbito administrativo possam ser objeto de controle abstrato de constitucionalidade quando se revistam de normatividade geral e abstrata $-\mathrm{e}$ as diversas ações diretas de inconstitucionalidade contra medidas provisórias são exemplo disso -, o embate interinstitucional decorrente da participação do Supremo Tribunal Federal na definição de políticas legislativas parece se dar, em maior medida, na seara em que a atividade legiferante é mais presente e ordinária, i.e., no âmbito do Legislativo. Ainda assim, a doutrina menciona casos em que o Executivo ignorou decisão proferida pelo Supremo Tribunal Federal em controle abstrato de normas. Nesse sentido, cita-se o caso em que a Presidência da República, mesmo antes da Emenda Constitucional n. 45, de 2004, editou medida provisória que incidia na mesma inconstitucionalidade previamente reconhecida pela Corte em outra medida provisória - ambas visavam a regulamentar regramento

\footnotetext{
${ }^{213}$ LEAL, Roger Stiefelmann. O efeito vinculante na jurisdição constitucional, op. cit., pp. 155-157.

${ }^{214}$ Idem, ibidem, loc. cit.
} 
trazido pela Emenda Constitucional n. 6, de 1996, o que por sua vez é vedado pelo artigo 246 da Constituição Federal. ${ }^{215}$

Não se está a afirmar que o Executivo não se preocupe ou não vislumbre prejuízos a projetos que pretenda implementar em razão da possível intervenção política do Supremo Tribunal Federal. ${ }^{216}$ Entretanto, mudanças de políticas legislativas mais sensíveis no mais das vezes envolvem atuação do legislador - quer em razão da necessidade de processo legislativo para reforma constitucional ou legal, quer em razão da própria necessidade de atuação do Legislativo para suprir a precariedade dos atos normativos gerais e abstratos do Executivo -, razão pela qual o Legislativo, conquanto possa agir sob alguma influência e controle do Governo, acaba por assumir a autoria de tais mudanças e, consequentemente, por cobrar institucionalmente por possível usurpação de competência e excesso de poder por parte do Judiciário. O Executivo não possui, por si só, instrumentos que lhe permitam sobrepor-se, de modo definitivo, às decisões do Supremo Tribunal Federal quando estas contem com vinculatividade de acordo com a Constituição ou com a legislação infraconstitucional: afinal, a implementação de sua agenda normativa que escape à função administrativa depende, como regra, de ato complementar por parte do Legislativo. Ao menos no plano federal, a atuação do Executivo no sentido de buscar controlar ou conter excessos da Corte, ou mesmo de garantir maior apoio à sua agenda política, pelo contrário, se dá menos num possível embate normativo entre decisões que se sobrepõem, e mais, conforme se verá, no plano mais estritamente institucional, mediante uso da competência da Presidência da República em nomear os integrantes que compõem o Supremo Tribunal Federal.

O Legislativo, por sua vez, não tem, em tese, sua atividade típica limitada pelo teor das decisões do Supremo Tribunal Federal - seja em sede concreta ou abstrata de controle - e das interpretações firmadas em súmulas vinculantes. As disposições constitucionais e infraconstitucionais que regulam a matéria deixam-no de fora de seu âmbito de incidência. ${ }^{217}$ Abre-se, com isso, maior espaço para possíveis embates

\footnotetext{
${ }^{215}$ Idem, ibidem, pp. 105-106.

${ }^{216}$ A exemplo do contexto da reforma da Previdência Social que se projetava nos idos de 2003 e que contou com polêmica manifestação do Ministro Marco Aurélio no sentido de sua inviabilidade. A esse respeito, ver: MENDES, Conrado Hübner. Controle de constitucionalidade e democracia. Rio de Janeiro: Elsevier, 2008, pp. 141 e ss.

${ }^{217}$ Idem, op. cit., pp. 215-217, apontando o autor inclusive decisões do Supremo Tribunal Federal em que este entendimento resta pacificado. No mesmo sentido, ver: LEAL, Roger Stiefelmann. $O$ efeito vinculante na jurisdição constitucional, op. cit., pp. 159-162. Esboçando entendimento diverso, no sentido da impossibilidade de o legislador reintroduzir no ordenamento a norma declarada inconstitucional, ver:
} 
institucionais no tocante à tentativa de sobreposição de decisões. O diálogo interinstitucional entre os dois Poderes - Legislativo e Judiciário, mormente sua alta cúpula - faz-se necessário em especial pelo fato de a Constituição não prever quem detém a última palavra no plano normativo. Quando muito, pode-se extrair da inteligência do sistema que o Supremo Tribunal Federal profere a última palavra no tocante ao controle de constitucionalidade das normas $^{218}$, mas, dada a não vinculação do legislador à atuação judicial nesse campo, nada impede que haja sucessivas reinserções no ordenamento de normas declaradas inconstitucionais, que dependerão de novos processos constitucionais para serem extirpadas do ordenamento. Roger Leal Stiefelmann apresenta, nesse sentido, alguns casos brasileiros de "recalcitrância legislativa", ligados, entretanto, à atuação de Legislativos estaduais. ${ }^{219}$ No âmbito federal, conquanto tais casos não sejam inexistentes $^{220}$, parece correto afirmar que o Congresso Nacional demonstra algum grau de complacência com as decisões do Supremo Tribunal Federal, ainda mais quando a política legislativa objeto de intervenção judicial seja de alta relevância.

Uma explicação para essa realidade decorre do fato de que, muito embora o Legislativo não quede restringido pelas decisões do Supremo Tribunal Federal e não haja institucionalmente um órgão designado a proferir a última decisão - de forma verdadeiramente vinculante -, toda e qualquer repetição político-normativa por parte do Legislativo que busque superar entendimento prévio da Corte será passível de novo controle de constitucionalidade. Se por um lado isso faz o fiel da balança pender em favor do Judiciário, que detém, aparentemente, maior poder político na realização do juízo da adequação normativa, por outro permite desenvolver o diálogo institucional de que se falou. $^{221}$

TAVARES, André Ramos. Tribunal e jurisdição constitucional. São Paulo: Celso Bastos Editor, 1998, pp. $120-121$.

218 "Do ponto de vista procedimental, a Constituição brasileira de 1988 reserva ao STF a última palavra não só para o controle de leis, mas inclusive de emendas constitucionais." MENDES, Conrado Hübner. Direitos fundamentais, separação de poderes e deliberação, op. cit., p. 215.

${ }^{219}$ LEAL, Roger Stiefelmann. O efeito vinculante na jurisdição constitucional, op. cit., pp. 104-105.

${ }^{220}$ MENDES, Conrado Hübner. Direitos fundamentais, separação de poderes e deliberação, op. cit., pp. 224-226.

${ }^{221}$ Segundo destaca Conrado Hüber Mendes, a visão de que o sistema leva a uma sobreposição de rodadas de decisão é "insensível às negociações argumentativas informais que ocorrem entre os poderes e supõe o desacordo e o enfrentamento totais entre STF e o legislador, um jogo de soma zero com perdedor e vencedor. Tratar-se-ia de um braço de ferro polarizado, e não de um jogo de vetores que se somam e se acomodam. Numa interação desse tipo, há pouco lugar para a persuasão interinstitucional, e a única forma de prevalecer seria recorrer a um instrumento jurídico de maior autoridade (com a emenda, para o legislador)." Idem, ibidem, p. 216. 
A insistência na repetição de norma declarada inconstitucional pode, de um lado, estimular a Corte a reavaliar o juízo anteriormente realizado, o que se torna ainda mais plausível caso haja mudanças nas contingências fáticas envolvidas ou mesmo na composição subjetiva do órgão. Por outro lado, a prévia manifestação da Corte sobre a inconstitucionalidade de determinada matéria pode levar a que a reinserção legislativa considere as razões apontadas pela Corte, com o que se tem um aperfeiçoamento do regramento normativo - ainda que se possa contestar a legitimidade da Corte em participar desse processo. Segundo conclui Conrado Hübner Mendes,

o STF não decide no vácuo, livre de quaisquer constrangimentos. Tampouco
nota que, muitas vezes, a reação legislativa é mais sutil e que, para o legislador, a
emenda não é a única alternativa a uma lei declarada inconstitucional. Uma nova
lei ligeiramente modificada, que faça concessões aos testes constitucionais do
STF, ou mesmo uma lei idêntica à anteriormente invalidade, mas acompanhada
de um processo deliberativo mais intenso, podem ser estratégias políticas menos
custosas.

Assim, diante da inexistência de um mecanismo institucional que coloque fim ao possível ciclo de sobreposição entre decisões do Supremo Tribunal Federal e decisões legislativas que reiteram determinada norma no ordenamento, o sistema parece forçar a um diálogo institucional - ou ao menos deveria fazê-lo. Busca-se, assim, promover um processo de atuação conjunta na aplicação da Constituição pelo qual as decisões do Legislativo influenciem as do Judiciário - e vice-versa -, fomentando e aumentando o ônus argumentativo daquele que busca se sobrepor ${ }^{223}$. Esse diálogo, contudo, sempre envolve custos políticos, que parecem atingir nível mais agudo quando a decisão do Supremo Tribunal Federal trate de garantir direitos a minorias ou de suprir uma omissão legislativa sobre matéria altamente controvertida - em suma, quando envolva a proteção de direitos fundamentais. Qualquer tentativa de reversão de decisões dessas naturezas por via legislativa reabre a discussão sobre a matéria e, se caminhar em um sentido menos garantista que aquele apregoado pela Corte, pode acarretar prejuízos à imagem institucional do Legislativo - além de, é claro, poder reforçar a imagem do Supremo Tribunal Federal como sede de proteção contra incursões legislativas supostamente antidemocráticas que desrespeitem as minorias.

\footnotetext{
${ }^{222}$ Idem, ibidem, loc. cit.

${ }^{223}$ Idem, ibidem, pp. 191 e ss.
} 
Ademais, e ainda quando seja legítimo o interesse do Legislativo em reafirmar determinada política julgada inconstitucional, a insistência em tema declarado contrário à Constituição faz transparecer uma imagem de certo descomprometimento com as premissas democráticas, como se em todo e qualquer caso representasse um imotivado desrespeito ao quanto decidido pelo Supremo Tribunal Federal. Nesse sentido, soa razoável afirmar que seja o Supremo Tribunal Federal aquele que possui preponderância nesse diálogo, dado que a posição de independência institucional do Judiciário atribui uma carga valorativa e um apelo moral maior à leitura constitucional feita nesta sede, como se lhe coubesse a exclusividade na guarda e a última palavra na aplicação do Texto Magno.

A superação do posicionamento da Corte impõe maior ônus argumentativo e custo político mais elevado ao Legislativo, com o que suas decisões acabam, no mais das vezes, a condicionar e a pautar as novas escolhas do legislador, mesmo porque, ao fim e ao cabo, as novas políticas legislativas poderão ser igualmente objeto de controle. Pode-se citar como exemplo de recalcitrância do Congresso Nacional em questão sensível a tentativa de se reintroduzir uma forma de cláusula de barreira no sistema político nacional, que em outros moldes já teve sua inconstitucionalidade reconhecida pelo Supremo Tribunal Federal. Ainda assim, tem-se que a nova proposta (PEC n. 2, de 2007) busca fundamentar sua compatibilidade com o quanto previamente decido pela Corte no tocante à matéria. ${ }^{224}$

O desenvolvimento desse diálogo, contudo, pode encontrar barreiras ao se considerar a franca expansão política do Judiciário como um todo, e do Supremo Tribunal Federal em especial. O Legislativo tende a aceitar tais padrões de interação interinstitucional enquanto anteveja na atuação da Corte Constitucional um respeito mínimo à liberdade de conformação política do próprio Legislativo.

A mídia reverbera críticas do Legislativo à incursão mais incisiva do Supremo Tribunal Federal em questões políticas sensíveis - mormente quando se imiscui em matérias atinentes ao jogo político-eleitoral e à proteção dos direitos fundamentais. Fala-se muito em usurpação de competências e em violação e desrespeito ao princípio da separação de Poderes. No momento em que tais tensões chegarem ao limite, a solução encontra-se na possibilidade de o Congresso Nacional lançar mão de emenda à Constituição. Não para reafirmar determinada política, agora com status constitucional, dado que também a emenda pode ser objeto de controle, mas sim para readequar a estrutura das competências do Supremo Tribunal Federal. Por óbvio, uma emenda que

${ }^{224}$ Idem, ibidem, pp. 224-225. 
restringisse o rol de competências da Corte ou que mitigasse seus instrumentos de controle igualmente seria passível de controle pelo próprio órgão - e aqui pode-se imaginar um conflito institucional mais grave. Não obstante, trata-se de uma forma de reação que torna clara a insatisfação e o desconforto do Legislativo com os rumos que a função de controle exercida pelo Supremo Tribunal Federal vem tomando, o que por sua vez pode, no mínimo, incitar novamente um diálogo interinstitucional que fomente um movimento de contenção do ativismo por parte da própria Corte Constitucional.

No Brasil da Constituição de 1988 ainda não houve um ataque direto - efetivo do Congresso Nacional contra a expansão política do Supremo Tribunal Federal. Isso demonstra, de um lado, um maior comprometimento com princípios democráticos, independentemente dos juízos de se uma maior contenção da Corte fosse desejável e de se alguma mudança normativa na estrutura dos limites da função de controle pelo Judiciário fosse recomendável. O compromisso democrático busca uma autocomposição dos interesses mediante um controle mútuo do exercício das respectivas funções, com o que lançar mão de mecanismos que forcem uma alteração dos contornos institucionais mostrase como ultima ratio.

De outro lado, isso pode também ser explicado pelo fato de que a atuação política do Supremo Tribunal Federal beneficia, em alguma medida, os demais Poderes, dentro da ideia de que há, em certos casos, uma deferência voluntária de questões sensíveis à jurisdição constitucional. Ao tomar alguma decisão, o Judiciário acaba por assumir os custos políticos de sua intervenção, o que é especialmente interessante para os demais Poderes quando se está diante de temas essencialmente controversos. ${ }^{225}$

Destaca Mark Graber que, na realidade estadunidense, é comum que quando a Suprema Corte toma decisões políticas delicadas haja reação político-partidária que, não obstante alegue um injustificável ativismo judicial, aceita a decisão em sua substância e evita antagonismo e confrontos - em especial ao não apoiar qualquer legislação que pudesse mitigar os poderes da Corte, sob o argumento de que isso prejudicaria a independência do Judiciário. Isso denotaria, em verdade, um aproveitamento político da atuação das Cortes Constitucionais, embora os partidos em muitos casos se vejam impelidos a sustentar um discurso contra tal atuação. Com isso, afirma o autor que conquanto os atores políticos desejem que o eleitorado culpe o Judiciário por tomar tais decisões políticas, eles tendem a facilitar a deferência dessas discussões à seara da

${ }^{225}$ GRABER, Mark A., op., cit., p. 42. 
jurisdição constitucional quando tenham razões suficientes para acreditar que a Corte sustentará políticas que eles apoiam internamente, mas que não podem fazê-lo publicamente sem riscos à coalizão ou ao apoio do eleitorado. ${ }^{226}$

$\mathrm{Na}$ realidade nacional, a tentativa mais recente e mais sensível de limitação externa do Supremo Tribunal Federal - i.e., imposta pelo Congresso Nacional - é representada pela proposta de emenda constitucional n. 33, de 2011, que, consoante já se apontou, pretende, dentre outras alterações, submeter as decisões sobre controle de constitucionalidade de emendas constitucionais proferidas pela Corte a posterior apreciação do Congresso Nacional. Eventual aprovação dessa proposta traria profundas alterações ao diálogo interinstitucional de que se falou, dado que tornaria o Legislativo o detentor da última palavra no tocante ao controle normativo de decisões políticas de natureza eminentemente constitucional - o que, por sua vez, poderia igualmente abrir caminho para um progressivo movimento no sentido de se restringir, cada vez mais, a atuação do Supremo Tribunal Federal mediante promulgação de novas emendas constitucionais que readéquem seu rol de competências.

3.1.2 A nomeação dos Ministros e o papel contramajoritário do Supremo Tribunal Federal

O Poder Constituinte de 1988 manteve a tradição das demais Constituições republicanas brasileiras no tocante à nomeação dos Ministros que integram a alta cúpula do Judiciário, mantendo a prevalência da Presidência da República no processo de composição da Corte. ${ }^{227}$ Fala-se em preponderância do Executivo basicamente por duas razões. A primeira é a de que nesse processo de escolha, a Lei Magna conferiu-lhe o poder exclusivo de nomear candidatos ao cargo, atribuindo-lhe, para o exercício dessa competência, grande discricionariedade, devendo apenas observar, como critérios objetivos, que o nomeado seja brasileiro nato (cf. seu artigo $12, \S 3^{\circ}$, IV) com idade entre trinta e cinco e sessenta e cinco anos (cf. artigo 101, caput). Ainda que a Constituição ainda exija que o candidato conte com reputação ilibada e notável saber jurídico (cf. artigo 101, caput), tais conceitos possuem definição fluida e bastante subjetiva, não havendo parâmetros legais que os balizem minimamente. Na avaliação dessas duas qualidades

\footnotetext{
${ }^{226}$ Ibidem, ibidem, pp. 42-43.

${ }^{227}$ PEIXOTO, Leonardo Scofano Damasceno. Supremo Tribunal Federal: composição e indicação de seus ministros. Rio de Janeiro: Forense; São Paulo: Método, 2012, p. 118.
} 
deveria desempenhar papel relevante o Senado Federal, dado que, pelo parágrafo único do artigo 101 da Constituição Federal, a maioria absoluta de seus membros deve aprovar a nomeação feita pelo Presidente da República. Reside justamente na participação do Senado Federal a segunda razão de se afirmar que o Executivo conta com prevalência no processo de escolha: conforme aponta a doutrina, sua participação tem sido historicamente pro forma, apenas chancelando a nomeação feita, sem que haja escrutínio do candidato que possa efetivamente representar algum risco de não aprovação da escolha. ${ }^{228}$

Seja como for, recai nessa competência a maior influência interinstitucional que a Presidência da República pode exercer no sentido de traçar, minimamente, os rumos da jurisdição constitucional e da atuação política do Supremo Tribunal Federal. Havendo discricionariedade e exclusividade no ato de nomeação, o Executivo é livre para indicar candidatos ao cargo de acordo, v.g., com suas preferências políticas, caso sejam conhecidas, e com seu padrão de atuação profissional, no sentido de avaliar as teses que sustenta e defende - na hipótese de, como sói ocorrer, atuar no ramo do Direito. Trata-se de escolha, sobretudo, de natureza política, que pode desempenhar papel crucial no desenvolvimento, na manutenção, na legitimação e mesmo na proteção de políticas que a coalizão governamental sustenta ou pretende implementar. Essa ideia se coaduna com o defendido por Ran Hirschl ${ }^{229}$, no sentido de que o processo de expansão da influência do Judiciário seria mecanismo deflagrado pelas elites dominantes no sentido de aumentar seu poder político, como que no intuito de tornar a Corte Constitucional mais um elemento de reforço e proteção da legitimidade das políticas que se busca implementar.

A doutrina que defende esse posicionamento não sustenta que, em razão da forma de nomeação dos membros de Tribunais Constitucionais - em modelos semelhantes ao brasileiro -, haveria uma subserviência da Corte à ideologia e às preferências políticas de grupos políticos dominantes. A independência dos membros do Judiciário, própria à democracia, rompe com qualquer presunção nesse sentido, e permite, teoricamente, que um membro nomeado atue e defenda quaisquer posicionamentos, mesmo contrariando teses que defendia ou sustentava anteriormente e que possam ter motivado sua indicação ao cargo. A ilação feita toma por base um argumento mais sutil, de que a própria forma de indicação e composição desses Tribunais faria com que eles se tornassem órgãos a favor

\footnotetext{
${ }^{228}$ Idem, ibidem, loc. cit.

${ }^{229}$ HIRSCHL, Ran. Towards juristocracy: the origins and consequences of the new constitutionalism, op. cit., pp. 31 e ss.
} 
das elites dominantes, como se houvera uma inclinação naturalmente decorrente do processo de escolha.

Toma relevância, nessa discussão, a ideia de que as Cortes Constitucionais atuariam como instituições contramajoritárias, i.e., impondo políticas em contrariedade com a ideologia de blocos majoritários e em proteção de grupos minoritários que não conseguiriam respaldo para suas preferências nas vias ordinárias de formação de políticas nacionais. Esse viés é inclusive apontado como elemento legitimador da interferência política das Cortes, no sentido de que lhes caberia garantir uma democracia substancial que tutele os interesses de minorias. ${ }^{230}$

Com base nessa premissa, defende Robert $\operatorname{Dahl}^{231}$, no contexto estadunidense, que muito embora a Suprema Corte seja um partícipe da tomada de decisões políticas, na medida em que tem de efetuar decisões e tomar posicionamentos sobre questões controversas, não atua, como regra, em dissonância com as preferências políticas das elites dominantes. Aponta como ponto crucial para essa conclusão a própria forma de sua composição. Sustenta o autor que a Corte tem uma atuação mais efetiva em condicionar políticas - a exemplo de diferir sua implementação no tempo - do que realmente em impor decisões contra o grupo majoritário. Entende, assim, que a instituição milita em favor das maiorias dominantes, em especial atribuindo legitimidade às escolhas políticas feitas. Conclui que seria pouco realista, e até mesmo uma anomalia do ponto de vista democrático, entender que a Corte agiria com a precípua finalidade de defender minorias contra maiorias políticas. Esse padrão apenas encontraria exceção em momentos de grande instabilidade política no tocante a questões-chave. Afirma, com isso, que exceto em

períodos curtos de transição em que antigas alianças se desintegram e as novas ainda se debatem para tomar o controle das instituições políticas, a Suprema Corte é inevitavelmente parte da aliança nacional dominante. Sendo um elemento da liderança política da aliança dominante, a Suprema Corte, é claro, suporta as políticas de maior importância da aliança. Por si própria, a Corte é quase impotente para afetar os rumos da política nacional. Na ausência de acordo substancial dentro da aliança, uma tentativa da Corte de fazer política provavelmente leva a desastres, como a decisão no caso Dread Scott e os casos do início do New Deal demonstram. (...) [O]s casos das últimas três décadas envolvendo liberdade de negros, culminando na agora famosa decisão sobre integração em escolas, são exceções a essa generalização. ${ }^{232}$

\footnotetext{
${ }^{230}$ MENDES, Conrado Hübner. Direitos fundamentais, separação de poderes e deliberação, op. cit., pp. 7274.

${ }^{231}$ DAHL, Robert, op. cit.

${ }^{232}$ Idem, ibidem, p. 293 (tradução livre). Defendendo essa mesma ideia, Mark Graber destaca que com "a importante exceção do New Deal, sempre que uma maioria nacional prevalecente claramente suportou uma
} 
No desenvolvimento de seu argumento, Dahl avalia a periodicidade de nomeação de ministros, o tempo transcorrido entre a implementação de uma política legislativa e a eventual decisão de inconstitucionalidade da Suprema Corte, argumentando que, em um grande número de casos, esse lapso temporal foi superior a quatro anos, quando já não se poderia afirmar categoricamente que sua atuação efetivamente contrariaria a aliança majoritária então existente. ${ }^{233}$ Essa ideia permite, sobretudo, retirar, em parte, a discussão a respeito da influência política de Cortes Constitucionais de um pretenso conflito entre maiorias e minorias políticas. O enfoque de Dahl parece recair, em especial, menos nessa possível contraposição, e mais no destaque de se a Suprema Corte opera e consegue operar de forma a impor políticas próprias desvinculadas dos desejos de alianças majoritárias.

Não obstante, o debate sobre o papel contramajoritário de Tribunais Constitucionais ocupa e divide a doutrina. ${ }^{234}$ A discussão, contudo, deve ter seus parâmetros bem delimitados.

Se por intervenção contramajoritária quer-se aludir a uma atuação que (i) busca impor jurisdicionalmente políticas (positivas ou negativas), inclusive sob o pretexto de se proteger direitos de minorias, num processo que (ii) se sobrepõe às escolhas majoritárias decorrentes do processo político-legiferante e é apartado de instituições efetivamente representativas no sentido democrático-eleitoral e não pode ser politicamente responsabilizado, então a expansão judicial no campo político certamente envolve um

política, a Suprema Corte declarou-a constitucional. Sempre que a Suprema Corte declarou uma política inconstitucional, nenhuma maioria nacional prevalecente claramente suportava tal política." GRABER, Mark, op. cit., p. 71 (tradução livre).

${ }^{233}$ Para uma crítica à análise de Robert Dahl, ver: CASPER, Jonathan D. "The Supreme Court and national policy making”, in: The American Political Science Review, v. 70, n. 1 (mar. 1976), pp. 50-63. O autor rebate o corte temporal empregado por Dahl e a restrição de casos que foram considerados - que, por exemplo, não levam em consideração decisões em que, muito embora não tenha havido declaração de inconstitucionalidade, a Suprema Corte firmou interpretações importantes quanto a políticas nacionais. Argumenta, sobretudo, que Dahl faz uma análise que coloca a Corte em uma "no-win situation", dado que considera, por exemplo que sempre que sua decisão foi de alguma forma superada por nova política, ou que foi mantida mas sem grandes discussões e debates políticos, restaria demonstrado o baixo grau de influência política da Corte. Casper argumenta, pelo contrário, que mesmo nesses casos, as decisões acarretam reestruturações e acomodações ao sistema político, e que, pelo contrário, as decisões da Suprema Corte mostram que ela desempenhou papel importante na definição dos rumos de importantes políticas. Idem, ibidem, pp. 56 e ss.

${ }^{234}$ V.g., BICKEL, Alexander M. The least dangerous branch: the Supreme Court at the bar of politics. $2^{\mathrm{a}}$ edição. New Heaven: Yale University Press, 1986, pp. 16 e ss. O autor fala na dificuldade contramajoritária, defendendo que a interferência política do controle de constitucionalidade milita contra elemento essencial à democracia, qual seja, a elaboração e implementação de políticas como sendo parte do processo eleitoral e fruto de instituições representativas. Não obstante, reconhece que o Judiciário possui certas qualidades para o exercício dessa função de controle normativo-político - a exemplo da capacidade de lidar com questões relativas a princípios - que são cruciais para a definição dos valores duradouros da sociedade. 
papel contramajoritário e pode, nesse contexto, ter sua legitimidade contestada por diversos argumentos (inclusive aquele que destaca uma pretensa falta de legitimação democrática).

Ainda assim, tais críticas parecem desconsiderar que a participação política de Cortes Consitucionais no mais das vezes insere-se dentro de um (desejável) diálogo interinstitucional, que pode não apenas contar com a participação de atores políticos na composição de seus membros, mas também com uma interação mútua entre agentes políticos e jurisdicionais no sentido da construção e na delimitação do regramento constitucional. O papel contramajoritário, conquanto existente nesse viés, não pode ser entendido como se Tribunais Constitucionais atuassem no vazio e desatentos à realidade política em que se inserem. Decisões que contrariem as preferencias das alianças majoritárias e mesmo uma intervenção mais ativista das Cortes são efeitos naturais embora nem sempre desejáveis - do processo de expansão do poder judicial mediante o exercício do controle de constitucionalidade. Embora esse processo seja alvo de críticas, a doutrina constitucional parece não ter ainda encontrado uma alternativa satisfatória que permita um controle efetivo do processo político que defenda uma ideia substancial de democracia (para cuja definição também deve confluir a interação entre todos os Poderes).

O processo decisório político muitas vezes alija minorias da tutela de direitos importantes, ou mesmo reluta em garantir prerrogativas à própria base eleitoral majoritária - por questões orçamentárias, por exemplo -, e a interferência política do Judiciário, mesmo que apenas transfira o problema de sede e nem sempre garanta uma decisão mais adequada e correta, permite ao menos que se institucionalize um novo fórum de debates de questões sensíveis que resta, em tese, imunizado das vicissitudes da seara políticopartidária.

O papel contramajoritário pode, contudo, ser também compreendido em um viés mais específico, no sentido de se avaliar se as Cortes Constitucionais atuam contra preferências políticas de maiorias momentaneamente no poder. O argumento de Dahl, há pouco apresentado, é relevante nesse ponto. Ainda que o processo de nomeação dos membros das Cortes represente uma importante influência nos rumos de seu padrão de atuação, também é razoável supor que a independência judicial permite que seus membros atuem de acordo com suas próprias convicções e independentemente de concepções da maioria política de que o órgão responsável pelas indicações faz parte. Em muitos casos, o Judiciário define uma política nacional sobre a qual não há, efetivamente, um 
posicionamento claro do grupo majoritário, ou mesmo altera uma política legislativa muito tempo após esta ter sido introduzida no sistema, de modo que pode não se ter elementos para afirmar, em tais casos, se sua interferência realmente contraria as pretensões políticas de dada maioria.

Decorre daí a acuidade do argumento de Dahl no sentido de evitar a estrita discussão entre contraposição de vontades de maiorias e minorias. O autor talvez não considere, contudo, efeitos mais sutis que decorrem da interferência da Suprema Corte, o que o leva à conclusão de que sua influência política seria menos relevante do que a doutrina costuma apontar. Tal influência não se mede apenas pela ideia de contraposição a uma maioria estabelecida ou de conseguir extirpar definitivamente determinada lei (e sua política subjacente) do ordenamento, mas igualmente em condicionar o timing da agenda política nacional e a interpretação e aplicação de políticas legislativas já positivadas.

Com base nessas premissas, pode-se afirmar que o Supremo Tribunal Federal exerce relevante papel político no contexto nacional. As decisões proferidas em questões mais sensíveis muitas vezes não permitem afirmar se haveria uma atuação verdadeiramente contramajoritária no segundo sentido acima apontado.

A título exemplificativo, a discussão acerca da cláusula de barreira teve seu julgamento postergado por quase dez anos, de modo que as preferências da maioria que positivaram aquele regramento poderiam não mais reverberar no contexto político existente quando da decisão. A construção jurisprudencial da fidelidade partidária decorreu, em verdade, de uma mudança no entendimento da própria Corte e não resultou da declaração de inconstitucionalidade de qualquer norma então existente, mas de uma releitura dos princípios constitucionais e da extração de novas regras - a partir desses princípios - pelo próprio Supremo Tribunal Federal. A despeito do debate políticopartidário que esse julgamento ensejou, não parece haver elementos que permitam antever um ataque direto às preferências da aliança majoritária então existente. Outros casos mais relevantes versavam, especialmente, sobre tutela de direitos fundamentais altamente controvertidos na seara política - v.g, abortamento de fetos anencefálicos ${ }^{235}$ e união estável homoafetiva $^{236}$ - e em relação aos quais o Legislativo voluntaria ou involuntariamente não atingia consenso deliberativo. Dada a grande divisão política que tais questões envolvem,

\footnotetext{
${ }^{235}$ ADPF n. 54/DF. Relator Ministro Marco Aurélio Mello, j. em 12.04.2012.

${ }^{236}$ ADI n. 4.277/DF e ADPF n. 132/RJ, ambas de relatoria do Ministro Ayres Britto e j. em 05.05.2011.
} 
torna-se difícil a perquirição a respeito de se as decisões proferidas pelo Supremo Tribunal Federal eram ou não efetivamente contrárias às pretensões das alianças majoritárias, podendo-se estar diante daquelas situações em que, muito embora a elite dominante apoie a política imposta pela Corte, não pode manifestar esse apoio publicamente sem riscos à higidez da coalizão e à manutenção do apoio eleitoral.

No entanto, há, inegavelmente, uma atuação contramajoritária do Supremo Tribunal Federal na primeira das acepções indicadas. A Corte tornou-se verdadeiro fórum de rediscussão de escolhas legislativas, como resultado do arranjo normativo do sistema de controle de constitucionalidade brasileiro e da atual política institucional do órgão. A alta cúpula do Judiciário efetivamente impõe e define políticas de relevância nacional e altamente controvertidas, em um processo que se torna ainda mais agudo na seara da proteção de direitos fundamentais de minorias - quando então avoca até mesmo a função de preencher o silêncio do legislador. Mais que isso, condiciona e movimenta a agenda do Congresso Nacional e do Governo, seja no timing, seja no próprio processo deliberativo no âmbito da legiferação, dado que suas decisões acabam por ser consideradas e ponderadas pelos atores políticos em decisões normativas futuras.

Esse papel contramajoritário, por sua vez, se desenvolve num contexto em que a Corte também sofre influxos dos demais Poderes. Novamente, o órgão não opera no completo isolamento. E a competência do Presidente da República de nomear seus membros desempenha papel importante na definição da missão assumida pela jurisdição constitucional. Basta se imaginar que da atual composição do Supremo Tribunal Federal, oito ministros foram indicados pelo partido que atualmente ocupa a chefia do Executivo federal. Voltando-se novamente ao argumento de Dahl, não parece crível, nessas circunstâncias, que a intervenção política da alta cúpula do Judiciário se dê em absoluto confronto com as pretensões políticas da aliança governante. O Supremo Tribunal Federal, conquanto independente, é fruto de escolhas dessa maioria, e, ainda que não devam qualquer subserviência, é de se supor que seus membros comunguem de concepções que convirjam minimamente com aquelas da aliança majoritária.

Entretanto, mais importante que definir se há ou não um confronto entre opções das maiorias e minorias talvez seja compreender qual a real influência da ingerência política do Supremo Tribunal Federal e, constatando-se serem substanciais na realidade brasileira, buscar elementos que permitam refletir se este desenho institucional se mostra o mais adequado no contexto democrático. Ao se falar que sua atuação é contramajoritária 
em razão de permitir a definição de políticas fora dos canais partidários, há que se perquirir se existem argumentos que legitimem essa atuação dentro do contexto nacional e compreender que a mesma ocorre sob relativa influência do Executivo e do Legislativo.

3.2 A ampliação pretoriana do regramento constitucional: a ratio decidendi das decisões do Supremo Tribunal Federal e a liberdade do legislador

Consoante exposto anteriormente, o legislador atribuiu às decisões proferidas pelo Supremo Tribunal Federal em sede principal de controle de constitucionalidade e às sumulas vinculantes "efeito vinculante" aos destinatários indicados em cada caso (cf. artigo 102, §2º da Constituição Federal c/c artigo 28, par. ún., da lei n. 9.868, de 1999; artigo 103-A, caput, da Constituição Federal; e artigo 10, §3º, da lei n. 9.882, de 1999). Cumpre, assim, realizar uma análise mais focada nas próprias dimensões que esse atributo assume diante do contexto da revisão judicial exercida pela Corte.

Afirma Roger Stiefelmann Leal que a vinculatividade representa um acréscimo eficacial às decisões de controle abstrato de constitucionalidade, no sentido de se imputar aos demais Poderes a obrigatoriedade de, para além de observarem o quanto definido no dispositivo da decisão, aterem-se às razões de decidir expostas. ${ }^{237}$ Pressupõe-se que a expansão dos efeitos nesses moldes desestimularia atos de recalcitrância consubstanciados na reedição da norma declarada inconstitucional ou mesmo na positivação de norma que se paute em premissas semelhantes. ${ }^{238}$

$\mathrm{O}$ autor conclui que, pelo regramento constitucional e infraconstitucional brasileiro, o mesmo raciocínio aqui se aplica. Não haveria sentido lógico em interpretar a expressa atribuição de efeito vinculante às decisões de controle abstrato de

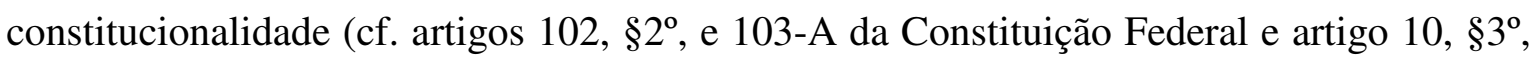
da lei n. 9.882, de 1999) como uma obrigatoriedade de observância apenas frente ao dispositivo de tais decisões. A eficácia erga omnes e os efeitos próprios à coisa julgada seriam suficientes para esse propósito. Pelo contrário, o legislador empregou termos diversos ("eficácia contra todos" e "efeito vinculante"), de modo que reconheceu a

\footnotetext{
${ }^{237}$ LEAL, Roger Stiefelmann. O efeito vinculante na jurisdição constitucional, op. cit., pp. 112-114.

${ }^{238}$ Idem, ibidem, loc. cit.
} 
autonomia dogmática dos institutos. ${ }^{239}$ Conclui, baseado inclusive em jurisprudência do Supremo Tribunal Federal, que o efeito vinculante deve ser compreendido como

\begin{abstract}
instituto voltado a tornar obrigatória parte da decisão diversa da dispositiva aos órgãos e entidades relacionadas no texto normativo. Assim, seu objetivo transcende o decisum em seu sentido estrito, alcançando os seus fundamentos determinantes, a ratio decidendi subjacente ao julgado. Da vinculação aos fundamentos determinantes da decisão decorre, a exemplo dos demais países que adotam o efeito vinculante, a vedação aos seus destinatários de reproduzir em substância o ato declarado inconstitucional, de manter outros atos de conteúdo semelhante e de adotar via interpretativa diversa da acolhida nos julgados do Supremo Tribunal Federal em sede de controle principal de constitucionalidade. ${ }^{240}$
\end{abstract}

Ao estipular os destinatários do efeito vinculante, o legislador deixou a si próprio fora desse rol. Com isso, não há, normativamente falando, um desvalor jurídico na recalcitrância por parte do Legislativo. ${ }^{241}$ Tratou-se desse assunto em capítulo precedente sob o prisma do diálogo interinstitucional, concluindo-se que a priori e em tese, o legislador pode reeditar a norma expurgada do ordenamento pela Corte, seja como simples ato de repúdio à intervenção indevida do Judiciário na matéria, seja até mesmo para fomentar o diálogo entre os Poderes no sentido de uma atuação conjunta na definição da inteligência das regras e dos princípios constitucionais.

No presente tópico, buscar-se-á dar outro enfoque à mesma circunstância, agora voltado às consequências do atributo da vinculatividade à própria estruturação, pelo Supremo Tribunal Federal, dos paradigmas de constitucionalidade.

Ao se ter atribuído ao Supremo Tribunal Federal a competência de controlar a constitucionalidade não apenas de leis, mas também de emendas à Constituição, o órgão foi erigido a verdadeiro guardião dos compromissos democráticos e, na prática, é quem detém a última palavra em questão de adequação normativa da atividade do legislador ${ }^{242}$ ressalvando-se, novamente, que institucionalmente o Legislativo não está vinculado às decisões da Corte, muito embora reafirmações de políticas já inquinadas de inconstitucionalidade sujeitem-no a novos e sucessivos controles pelo Judiciário.

A competência de rechaçar do ordenamento normas reputadas contrárias à Constituição já permitiria uma intervenção do Supremo Tribunal Federal em questões de alta relevância política. Entretanto, ao se lhe atribuir igualmente a competência para

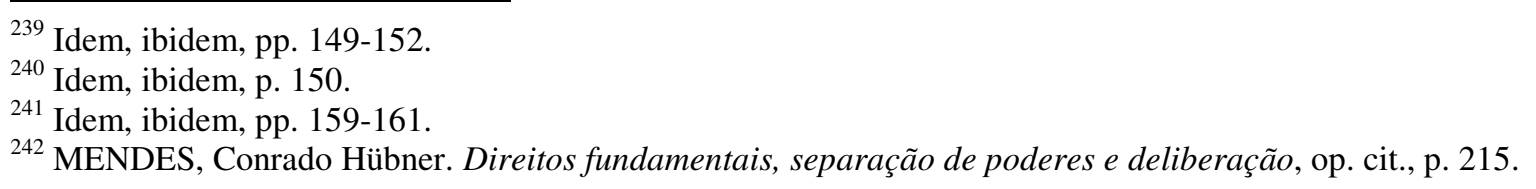


realizar em via principal o controle material de emendas à Constituição mediante a interpretação da amplitude e da extensão das normas superconstitucionais ${ }^{243}$ - as cláusulas pétreas previstas no artigo $60, \S 4^{\circ}$, da Constituição Federal -, tem-se que a Corte pode verdadeiramente interferir na construção dos regramentos constitucionais e fixar balizas que, em seu entendimento, não podem ser ultrapassadas por qualquer legislador, a menos que se esteja diante de uma ruptura constitucional. ${ }^{244}$ Manoel Gonçalves Ferreira Filho chega a afirmar que o Supremo Tribunal Federal passa a ser dotado de verdadeiro poder constituinte. $^{245}$

Esse fator alça sua função de controle, mesmo se referente à legislação ordinária, a um novo patamar. A fundamentação apresentada pela Corte em suas decisões passa a encerrar, em todo e qualquer caso, posicionamentos tanto sobre a interpretação, na essência, das normas constitucionais, quanto sobre as possibilidades que, segundo o órgão de controle, são admitidas em nosso sistema jurídico. O salto qualitativo no status da argumentação pauta-se na possibilidade de a Corte poder, em última análise, revestir sua ratio decidendi com justificativas ligadas à proteção e à aplicação de preceitos próprios às cláusulas pétreas, sobre as quais detém a prerrogativa de controle.

Basta imaginar as razões de decidir apresentada no caso da ADPF n. 132/RJ e da ADI n. 4.277/DF - que versavam sobre a união estável homoafetiva. Lembra-se aqui que, apesar de a Corte ter votado à unanimidade pela procedência das demandas, houve divergência quanto aos argumentos empregados ${ }^{246}$. A maioria julgadora, em consonância com o voto do Ministro relator, entendeu por atribuir interpretação conforme a Constituição ao artigo 1.723 do Código Civil, no sentido de reconhecer a aplicação do instituto da união estável a casais compostos por pessoas do mesmo gênero. O julgamento não se baseou no reconhecimento de que o dispositivo infraconstitucional violava frontalmente alguma regra expressa prevista na Constituição. Pelo contrário, a Corte extraiu uma interpretação sobre princípios sensíveis do Texto Magno ao mesmo tempo em que procedeu a uma leitura dos dispositivos relativos a seu artigo 226, que trata de instituições familiares.

\footnotetext{
${ }^{243}$ VIEIRA, Oscar Vilhena. A Constituição e sua reserva de Justiça (um ensaio sobre os limites materiais do poder de reforma), op. cit., pp. 23 e ss.

${ }^{244}$ MENDES, Conrado Hübner. Controle de constitucionalidade e democracia, op. cit., p. 169.

245 FERREIRA FILHO, Manoel Gonçalves. "O papel político do Judiciário e suas implicações", in: FRANCISCO, José Carlos, op. cit., pp. 229-231.

${ }^{246}$ Ver capítulo 2.2.2 supra.
} 
Ao realizar esse tipo de conformação e readequação da norma impugnada, há, reitere-se, tanto um efeito imediato quanto um mediato: o primeiro, relativo à implementação de uma nova política por via judicial que supre o silêncio legislativo atendendo, assim, o objetivo subjacente às ações ajuizadas; o segundo, a seu turno, referese à projeção da ratio decidendi ali empregada, que acaba por indicar aos demais Poderes que, no entender do órgão responsável pelo controle de toda a atividade legiferante (ordinária ou constitucional), nosso ordenamento não comporta qualquer discriminação que negue a uniões estáveis entre pessoas do mesmo gênero o status de entidade familiar, o que por sua vez estabelece um núcleo moral à proteção e à garantia de direitos e garantias fundamentais superconstitucionalizados. ${ }^{247}$

Diga-se o mesmo, dentre tantos outros casos, quanto à instituição pretoriana da fidelidade partidária, em que a Corte embasou-se na extração de regras específicas a partir da exegese de princípios constitucionais que comportam uma série de desenhos institucionais, impondo novos corolários ao sistema político nacional - modelo decisório este que vem também sendo adotado no julgamento, ainda pendente, a respeito do financiamento de campanhas eleitorais. Para o engessamento dessa regra, até mesmo contra tentativa de reforma pelo constituinte derivado, basta que o Supremo Tribunal Federal busque atribuir à sua ratio decidendi a imunização própria à tutela das cláusulas pétreas, ainda que o atributo da superconstitucionalidade apenas atinja, de maneira expressa, o exercício do direito de voto (conforme artigo 60, $\S 4^{\circ}$, II, da Constituição Federal). A esse respeito, no entanto, destaca Oscar Vilhena Vieira que no âmbito das cláusulas pétreas também devem ser incluídos aqueles direitos voltados à promoção da democracia, com o que direitos diversos políticos passam a integrar seu núcleo de proteção. $^{248}$

Nesses casos, e como efeito sistêmico, tem-se que nem mesmo por emenda constitucional seria admissível proceder a alguma alteração da decisão política subjacente à fundamentação do Tribunal, dado que, para se chegar a tal conclusão, foi manejada a aplicação de direitos fundamentais que contam com proteção contra o poder de reforma constitucional.

\footnotetext{
${ }^{247}$ Sobre a inteligência que se deve extrair da expressão "direitos e garantias individuais" prevista no artigo $60, \S 4^{\circ}, \mathrm{IV}$, da Constituição Federal, ver: VIEIRA, Oscar Vilhena. A Constituição e sua reserva de Justiça (um ensaio sobre os limites materiais do poder de reforma), op. cit., pp. 244-246.

${ }^{248}$ Idem, ibidem, loc. cit.
} 
Desse modo, o modelo brasileiro de controle normativo dota de peculiaridades o conceito de vinculatividade de que se falou. O Legislativo, se por um lado não está obrigado a observar as razões de decidir expostas no exercício do controle abstrato de constitucionalidade ou mesmo a normatividade que emerge do enunciado de súmulas vinculantes, por outro lado vê sua liberdade mitigada na medida em que a argumentação do Tribunal Constitucional passa a desenvolver a rede normativa decorrente de regras e princípios erigidos como cláusulas pétreas. A interpretação feita em sede de jurisdição constitucional, com isso, assume nuances como se fora expressão do próprio constituinte originário, no sentido de expressar a reserva de justiça da Constituição que queda fora das possibilidades de escolhas legislativas dentro do sistema vigente.

Esse método de criação e concretização, pela atuação da jurisdição constitucional, de paradigmas de constitucionalidade imunizáveis mediante o discurso argumentativo das cláusulas pétreas agudiza o processo de judicialização da política. Abre-se espaço para uma atuação judicial diretiva dos canais ordinários e constitucionais de formação de políticas nacionais, com apresentação de razões de decidir que se projetam para o futuro e contra o que os atores políticos não possuem mecanismos institucionais para se desvencilharem.

A expansão política da jurisdição constitucional, nesse aspecto, torna-se, na prática, uma forma de vinculação do legislador, a despeito da liberdade institucional que possui.

$\mathrm{Na}$ proteção de direitos e garantias fundamentais, sobressai uma atuação jurisdicional de controle que busca integrar (positiva ou negativamente) direitos de minorias ao sistema jurídico e que, conquanto possa ser mais ou menos ativista, pauta-se, $a$ priori, num processo resultante da ponderação entre princípios e valores em jogo. Pode haver, de certo, a sobreposição das escolhas do legislador, mas sob o argumento de que a escolha legislativa não contempla direitos que estão devidamente constitucionalizados. Dada a impossibilidade de se estabelecer uma hierarquiazação abstrata entre princípios constitucionais, decorre daí um inegável elemento de insegurança jurídica. Mesmo que a ratio decidendi possua sempre um potencial de projeção para condicionar escolhas políticas que se apoiem em justificações semelhantes, as decisões proferidas decorrem de concretizações casuísticas e ponderações de princípios feitas caso a caso, que muitas vezes não podem ser generalizadas. Pode-se imaginar, nesse aspecto, os efeitos da decisão sobre 
união estável homoafetiva ${ }^{249}$ para o controle de constitucionalidade de eventual lei que, muito embora não negue a aplicação do instituto a casais formados por pessoas do mesmo gênero, negue-lhes o direito à adoção - questão que, embora tangenciada, não foi, prudentemente, definida pela Corte naquele julgamento.

A situação assume outra gravidade no tocante à proteção de preceitos constitucionais referentes às balizas do próprio sistema político, e as preocupações levantadas pelas críticas ao ativismo judicial tornam-se ainda mais relevantes e permitem vislumbrar um viés desse fenômeno que vai além da atividade jurisdicional em que se profiram decisões com efeitos claramente aditivos ou substitutivos.

Ainda quando atue no sentido estrito de anular normas inconstitucionais - i.e., a jurisdição constitucional em seu aspecto funcional de "legislação negativa" -, um Tribunal Constitucional pode fazê-lo com base em sua própria ponderação a respeito dos preceitos que decorrem de princípios políticos tão sensíveis quanto abstratos e que, em tese, admitem um sem número de concretizações políticas. Pode-se pensar na invalidação de escolhas legislativas que, conquanto não contem com patente inconstitucionalidade, vão de encontro às concepções da Corte a respeito de qual deva ser a leitura a ser extraída de princípios da separação dos Poderes e do federalismo, por exemplo, ou da garantia de um sistema adequado de representatividade. $\mathrm{O}$ ativismo transparece, aqui, na medida em que o Tribunal Constitucional reconhece a sua interpretação sobre tais princípios e valores como a mais adequada dentro do sistema constitucional, imputando a essa leitura uma carga moral como se fora a mais correta forma de proteção e desenvolvimento das instituições democráticas, em prejuízo das demais. Em muitos casos, menos que ponderação de valores contrapostos nos moldes da proteção de direitos fundamentais - isto é, caso a caso mediante cotejo dos valores envolvidos em uma dada situação -, verifica-se na ratio decidendi a verdadeira extração de regras pretorianas que visam a dar maior concretude aos limites impostos pelo constituinte originário quanto às possibilidades de conformação do sistema político.

A esse respeito, afirma Cristina Queiroz que a

regra geral é a de que os tribunais, e em particular os tribunais de justiça constitucional, se devem refrear de tomar em consideração os factos legislativos. Os princípios da "separação de poderes" e do "Estado de direito" impedem que os tribunais entrem a valorar as escolhas legislativas. Só quando o exercício do

\footnotetext{
${ }^{249}$ ADI n. 4.277/DF e ADPF n. 132/RJ, ambas de relatoria do Ministro Ayres Britto e j. em 05.05.2011.
} 
poder legislativo se aproxima perigosamente de uma "área constitucionalmente proibida" (: reserva de constituição), como no caso dos direitos, liberdades e garantias, a relevância dos factos legislativos se tornaria crucial, não podendo então nenhuma decisão individual ser isolada da consideração desses factos. $\mathrm{O}$ tribunal passa a controlar a justificação apresentada pelo legislador.

A tendência geral vai no sentido de se conceder um amplo espaço de liberdade de conformação ao legislador, declarando-se unicamente como inconstitucionais os actos que não possam ser justificados de um ponto de vista de direito constitucional (: teste negativo), não quando não correspondam a uma específica “concepção" constitucional (: teste positivo). ${ }^{250}$

Na realidade brasileira, entretanto, a "reserva de constituição" - ou a "reserva de justiça" de que fala Oscar Vilhena Vieira ${ }^{251}$ - atinge não apenas a proteção dos direitos fundamentais - dentre os quais pode-se também fazer compreender diversos direitos de natureza política -, mas também preceitos claramente voltados à estruturação política do Estado. A possibilidade do controle de emendas com base nessas cláusulas pétreas permite, assim, que um Supremo Tribunal Federal mais ativista atue de forma incisiva no estabelecimento de regras que decorrem desses preceitos, limitando a liberdade do legislador. Não sem motivo, Oscar Vilhena Vieira pondera que, na proteção das cláusulas que possuem o status da superconstitucionalidade, o juiz deve frear a tentação de preencher seu conteúdo, quando claramente aberto, a partir de seus próprios valores. ${ }^{252} \mathrm{O}$ Supremo Tribunal Federal, a seu turno, tem ensaiado incursões nesse campo, a exemplo da imposição da fidelidade partidária e da ratio decidendi que se desenha no julgamento a respeito do financiamento de campanhas eleitorais.

Não se está a questionar a legitimidade e a importância da Corte na proteção da Constituição. Sua atuação política, que possui fortes argumentos a seu favor ${ }^{253}$, sem dúvida pode fortalecer as instituições democráticas, em especial por permitir a abertura da discussão a respeito do alcance e da extensão dos princípios e valores constitucionais. ${ }^{254}$ Pretendeu-se aqui desenvolver a ideia de que o fato de competir ao Supremo Tribunal Federal estabelecer os limites últimos do poder de reforma constitucional alça sua ratio decidendi a um novo patamar, permitindo-lhe que, em muitos casos, realize o preenchimento do conteúdo valorativo das cláusulas pétreas. Ainda que se admita que isso seja uma consequência natural do viés político que assume sua função de controle, esse fator acaba por estabelecer limitações ao legislador, em contraposição à imunidade

\footnotetext{
${ }^{250}$ Queiroz, Cristina, op. cit., p. 292.

${ }^{251}$ VIEIRA, Oscar Vilhena. A Constituição e sua reserva de Justiça (um ensaio sobre os limites materiais do poder de reforma), op. cit., em especial pp. 222 e ss.

${ }^{252}$ Idem, ibidem, p. 235.

${ }^{253}$ V.g., ver: idem, ibidem, pp. 232 e ss.

${ }^{254}$ Idem, ibidem, p. 238.
} 
normativa que possui contra a vinculatividade das decisões proferidas em sede de controle abstrato e das súmulas vinculantes.

Essa intervenção, por outro lado, pode dar azo a grande insegurança jurídica. De um lado, pela diversidade de razões de decidir que decorrem da infinidade de casos em que a Corte é chamada a ponderar princípios constitucionais, que por sua vez dependem de análises específicas dos valores que se sobressaem em cada caso, impassíveis de ampla generalização. De outro lado, pela diversidade de razões de decidir que podem emergir de um único e mesmo caso, dado que em nosso sistema os Ministros, ainda quando convirjam quanto à solução final, podem apresentar votos individuais com fundamentações distintas uma das outras. Há, nesta última hipótese, uma indefinição a respeito de qual ratio decidendi deve ser considerada no sentido de representar o entendimento da Corte como um todo.

De todo modo, a desvinculação teórica do legislador permite, conforme já afirmado, uma constante sobreposição entre positivação normativa e apreciação judicial sobre a mesma matéria ou sobre políticas legislativas semelhantes. Ainda assim, o papel desempenhado pelo Supremo Tribunal Federal e os instrumentos de controle que possui o colocam em uma posição privilegiada na definição dos parâmetros de constitucionalidade. Pondo-se na posição de guardiã dos valores constitucionais, a Corte impõe um diálogo interinstitucional que se desenvolve no sentido de uma maior complacência do Legislativo em relação às leituras e interpretações por aquela feitas, que não raras vezes contam com o discurso imunizante da proteção das cláusulas pétreas contra supostas miopias de maiorias momentâneas.

Essa preponderância da Corte, conforme já se apontou, decorre de dois argumentos. O primeiro baseia-se no fato de que o "retrocesso" na proteção de direitos fundamentais de minorias, mediante a inserção ou reinserção de políticas cujas bases já foram declaradas inconstitucionais, acarreta forte estigma antidemocrático e inegáveis custos político-eleitorais ao Legislativo. O segundo antevê na contestação da interpretação dada pela Corte um claro conflito institucional em que o legislador é simplesmente posto como não complacente com as regras do jogo relativas ao sistema de freios e contrapesos, com o que resta obscurecida a necessária análise de se o Judiciário efetivamente ultrapassou os limites de sua função de controle e de se, com isso, mostra-se legítima e razoável a insistência do Legislativo em determinada política.

Nesse sentido, esclarece Conrado Hübner Mendes que, a 


\begin{abstract}
"[s]upremacia da Constituição", quando atrelada ao controle de constitucionalidade, é um conceito que esfumaça o conflito entre poderes. A Constituição "justa" poderá sempre aparecer como uma aspiração política e moral, independentemente de qual instituição tem a competência de proferir a última decisão. A revisão judicial não garante a supremacia da Constituição, mas da Corte. Ou melhor, da leitura que a Corte faz da Constituição. ${ }^{255}$
\end{abstract}

A imunidade normativa do legislador contra os efeitos da vinculatividade da ratio decidendi contrapõe-se, assim, ao próprio desenvolvimento do diálogo interinstitucional. Com isso, pode-se concluir, conforme o faz Cristina Queiroz, que, muito embora não caiba às Cortes Constitucionais a exclusiva interpretação da Constituição, o processo de constitucionalização e judicialização da política "restringe o âmbito de liberdade de conformação do legislador. A extensão e intensidade dessa vinculação faz crescer os elementos vinculados, diminuindo o seu espaço de 'autonomia política'". ${ }^{256}$

3.2.1 Entre o ativismo judicial e a autocontenção: a autorreferenciabilidade de competências como questão crucial

Dentro do contexto que se expôs acima, outra consideração que merece atenção volta-se, novamente, à política institucional da Corte Constitucional. A maior ou menor influência política do Supremo Tribunal Federal e a maior ou menor constrição que repercute na liberdade de atuação dos demais Poderes são resultados da forma pela qual a Corte encara suas funções frente aos compromissos estatais e lança mão dos instrumentos e mecanismos de controle que lhe são colocados à disposição.

Apesar de óbvio, não é demais lembrar que, mesmo quando reputada ativista, a Corte atua formalmente balizada pelas competências que lhe são atribuídas, em última análise, pela Constituição. A intensidade da ingerência política do Judiciário está também ligada, portanto, à própria definição das possibilidades e dos limites relativos à aplicação dos mecanismos de controle de constitucionalidade - e, igualmente, à utilização das súmulas vinculantes.

O Direito brasileiro nunca foi profuso em normas regulamentando especificidades do processo constitucional. A título exemplificativo, a regulamentação infraconstitucional

\footnotetext{
${ }^{255}$ MENDES, Conrado Hübner. Controle de constitucionalidade e democracia, op. cit., 159.

${ }^{256}$ QUEIROZ, Cristina, op. cit., p. 311.
} 
a respeito da ação direta de inconstitucionalidade, da ação declaratória de constitucionalidade e da arguição de descumprimento de direito fundamental sobreveio apenas em 1999. De outro lado, até hoje não há legislação específica que regulamente o mandado de injunção. A legislação existente, por sua vez, possui um viés muito mais procedimental, ainda que, em certa medida, regulamente os efeitos decorrentes das decisões proferidas naqueles instrumentos de controle (a exemplo da possibilidade de modulação de efeitos da declaração de inconstitucionalidade). Não há, entretanto, regras que delimitem, por exemplo, sob que parâmetros interpretativos a declaração de constitucionalidade ou de inconstitucionalidade mostra-se cabível. Não que tais parâmetros legais fossem desejáveis - dado que sua positivação poderia criar limitações prejudiciais à função de controle -, mas ainda assim possuem relevância na medida em que permitem compreender melhor os mecanismos de fiscalização.

Ante a tímida regulamentação dos instrumentos de revisão judicial, o Supremo Tribunal Federal passa a ser responsável por (i) delimitar seu âmbito de incidência e as especificidades de sua aplicação, (ii) definir as condições para que eles possam ser exercidos pelos entes legitimados, e (iii) desenvolver um entendimento relativo aos efeitos que podem ser deles extraídos no contexto das garantias da Constituição e dos précompromissos democráticos. Para tanto, ou cria regras a partir de suas próprias concepções ou vale-se de conceitos tomados de outros ramos processuais - seja para suprir vácuos normativos ou para aprimorar alguma regulamentação já existente. Há, nessa dinâmica, tanto um processo de autocriação ${ }^{257}$, como de heterorreferência atípica ${ }^{258}$.

Em qualquer caso, a aplicação das regras pertinentes aos mecanismos de controle - sejam positivadas ou resultantes de criação pretoriana - cabe, em última análise, à própria Corte Constitucional. Cumpre a esta, portanto, extrair do regramento existente o modo de ser e as possibilidades jurídicas decorrentes de cada um daqueles instrumentos, inexistindo qualquer outro órgão - interno ou externo ao Judiciário - que controle o exercício de sua função de controle. Há, nesse aspecto, uma competência autorreferencial, no sentido de que é o próprio Supremo Tribunal Federal que define a amplitude de sua

\footnotetext{
257 "Temos autocriação de uma regra processual quando certa autoridade estatal estabelece normas e padrões que ela mesma deve seguir". DIMOULIS, Dimitri; LUNARDI, Soraya, op. cit., p. 244 (realce original).

258 "Trata-se das hipóteses nas quais, após a primeira cristalização das regras do processo objetivo, o Tribunal Constitucional adota elementos processuais provenientes de outros ramos do direito processual, subjetivando o processo objetivo e submetendo-o a regras que não lhe são próprias." Idem, ibidem, p. 248 (realce original).
} 
competência no manejo dos instrumentos de controle de constitucionalidade e mesmo na utilização das súmulas vinculantes. ${ }^{259}$

A recente jurisprudência a respeito dos efeitos do mandado de injunção, na qual a Corte concluiu ser competente para suprir o vácuo normativo deixado legislador, resultou de uma reinterpretação do instituto pelo próprio Supremo Tribunal Federal, que até então equiparava seus efeitos àqueles da ação direta de inconstitucionalidade por omissão.

No mesmo sentido, o voto do Ministro Gilmar Mendes na reclamação n. 4.335/AC defende uma mutação constitucional que busca dotar de objetividade a declaração de inconstitucionalidade em sede de controle concreto. O Ministro aduz, para tanto, argumentos a respeito da própria sistemática do controle de constitucionalidade no Brasil, e, mais, estabelece, ainda que implicitamente, parâmetros relativos ao reconhecimento de mutações constitucionais, método interpretativo que também pode ser empregado em outros campos de fiscalização normativa.

O entendimento pelo cabimento da interpretação conforme em ação direta de inconstitucionalidade e também em arguição de descumprimento de preceito fundamental - conforme discutido na questão de ordem da ADPF n. 54 - e a delimitação de seus efeitos - em especial no tocante à possibilidade de o Supremo Tribunal Federal proferir decisões com efeitos aditivos sem inquinar a norma de inconstitucionalidade - decorreram da própria atividade decisória da Corte, antes mesmo da existência de qualquer menção legal à possibilidade de se empregar essa técnica em sede de controle abstrato.

Tais competências autorreferenciais conferem, assim, elasticidade ao sistema de controle de constitucionalidade e permitem que, ao fim e ao cabo, a própria Corte defina a sua competência para imiscuir-se em questões políticas, ainda que sob o pretexto de garantir a supremacia da Constituição e de conferir adequada proteção aos précompromissos nela insculpidos. Na delimitação da própria competência, por sua vez, os mais diversos vieses podem ser levados em consideração: especificidades não previstas em lei quanto às hipóteses de cabimento dos mecanismos de controle; critérios interpretativos que podem ser empregados no juízo de (des)valor da norma impugnada e sua respectiva

\footnotetext{
${ }^{259}$ Segundo Dimitri Dimoulis, "[q]uando não há métodos para constatar os limites de uma atividade decisória, a autoridade competente pode decidir conforme seu livre-arbítrio, indicando ela mesma os limites de sua competência. Isso equivale ao reconhecimento de uma competência ilimitada: 'faça o que quiser'. Com efeito, a autoridade que possui a competência para fixar sua competência (Kompetenz-Kompetenz) pode deslocar ao infinito seus limites, revendo constantemente sua decisão. Quando uma autoridade pode definir sua própria competência, temos a determinação auto-referencial de competência." DIMOULIS, Dimitri, op. cit., p. 212.
} 
extensão, a exemplo da tendência atual de a Corte extrair regras a partir de princípios políticos absolutamente abstratos e que comportam um sem número de escolhas legislativas; limites à atuação normativa do Supremo Tribunal Federal, quando então os Ministros falam em intervenção como "legislador positivo"; e efeitos a serem produzidos pelas decisões, a exemplo da discussão a respeito de critérios de admissibilidade de impugnação de norma cuja constitucionalidade tenha sido declarada em ação própria.

A competência para definir sua própria competência acaba por ser elemento essencial à expansão do Tribunal Constitucional na seara política. Com isso, a variação entre um posicionamento ativista ou de autocontenção é resultado dos contornos que a própria Corte atribui à sua função de controle, o que por sua vez é reflexo do quadro maior em que se insere sua política institucional em sentido amplo, fruto de seu ideário no tocante aos compromissos que deve assumir frente ao Estado e à sociedade e ao papel que deve desenvolver como guardiã da Constituição.

3.3 Controle de constitucionalidade e democracia

A atuação do Judiciário decorrente do exercício do controle de constitucionalidade envolve naturalmente o embate entre escolhas políticas, i.e., entre aquela feita pelo legislador, cuja norma que a reveste pode ser objeto de impugnação, e aquela feita pelo magistrado ao realizar o juízo de (des)valor constitucional - ainda que sob o viés do discurso jurídico. Trata-se de tensão idiossincrática à revisão judicial, e que pode ser perceptível mesmo na atuação de Tribunais Constitucionais que se pautem na autocontenção. Afinal, ainda que tenham especial apreço e deferência às escolhas legislativas, eventual invalidação normativa, por reconhecer a existência de patente inconstitucionalidade, pode traduzir - em especial quando se esteja no campo de princípios constitucionais - uma valoração do órgão jurisdicional a respeito dos limites materiais à atuação do legislador.

Nessa discussão, e considerando que o Judiciário é, portanto, chamado a fazer escolhas que, embora normativas, possuem também um viés político, assume relevância a 
questão da legitimidade do órgão de controle. ${ }^{260}$ Pondera André Ramos Tavares, entretanto, que a sedimentação histórica do papel da jurisdição constitucional na guarda das Constituições tem colocado o foco desse debate menos na existência de uma legitimidade tout court, e mais na perquirição a respeito do "sentido, alcance, extensão e limites da justiça constitucional” 261 .

Ainda assim, e dentre os muitos argumentos que são levantados contra a preponderância judicial no contexto do controle normativo ${ }^{262}$, o que envolve maior discussão é aquele relativo à legitimidade democrática.

Segundo Manoel Gonçalves Ferreira Filho, a democracia representativa pauta-se na premissa de que o povo se governa - e, portanto, define as políticas legislativas aplicáveis à sociedade - mediante representantes que escolhe. ${ }^{263}$ As Cortes Constitucionais, no mais das vezes (a exemplo do Brasil) não contam com representatividade, dado que seus membros são escolhidos por entes políticos, i.e., indiretamente. Nesse sentido, faltam ao magistrado a responsiveness e a accountability ${ }^{264}$, que seriam exigências substantivas do desenvolvimento democrático e qualidades indispensáveis aos representantes do povo. ${ }^{265} \mathrm{~A}$ jurisdição constitucional não seria, destarte, a instância adequada a refletir as aspirações sociais, razão pela qual seria questionável sua legitimidade para sobrepor suas valorações e ponderações àquelas do Legislativo - órgão com representatividade democrática por excelência - em casos que em que a inconstitucionalidade não seja patente.

Discute-se que tal argumento seria raso, dado que a própria natureza e função do Judiciário desaconselham sua composição mediante representatividade direta-eletiva, além de que a composição das Cortes Constitucionais decorreria de ato de órgãos efetivamente representativos, com o que seus membros possuiriam, ainda que indiretamente,

\footnotetext{
260 TAVARES, André Ramos. Teoria da justiça constitucional. Tese de livre docência. São Paulo: Universidade de São Paulo, 2003, pp. 501 e ss. Para uma análise sobre alguns posicionamentos sobre o tema, ver: MENDES, Conrado Hübner. Controle de constitucionalidade e democracia, op. cit., pp. 33 e ss.

${ }^{261}$ TAVARES, André Ramos. Tribunal e jurisdição constitucional, op. cit., p. 113.

${ }^{262}$ MENDES, Conrado Hübner. Direitos fundamentais, separação de poderes e deliberação, op. cit., pp. 96 e ss.

${ }^{263}$ FERREIRA FILHO, Manoel Gonçalves, "O Papel Político do Judiciário e suas Implicações", in: FRANCISCO, José Carlos, op. cit., p. 233.

264 “Responsiveness é uma atuação consentânea com a vontade do povo, claro está na medida em que ela se manifesta na oportunidade adequada (não evidentemente extraída de pesquisas de opinião). Acountability é a responsabilidade pela própria atuação, as 'contas' dessa atuação, para apreciação e sanção (no sentido positive ou negative do termo) por parte do 'mandante', o povo.” Idem, ibidem, pp. 233-234 (realces originais).

${ }^{265}$ Idem, ibidem, p. 234.
} 
legitimidade pautada em representação democrática. ${ }^{266}$ Não obstante, esse argumento funda uma série de outras discussões, de maior profundidade.

A alegada falta de representatividade direta não se presta adequadamente a contestar a existência de toda e qualquer legitimidade da Corte, mas, antes, leva a perquirir tanto a respeito dos limites da jurisdição constitucional como a respeito dos motivos pelos quais as decisões ali proferidas deveriam ser consideradas preponderantes sobre as escolhas legislativas (ainda que provisoriamente). Segue-se, com isso, uma discussão a respeito de porquê o controle de constitucionalidade se mostra uma sede mais adequada à garantia de pré-compromissos e à escolha de políticas fundamentais. A doutrina passa a exigir, assim, uma argumentação que justifique a revisão judicial a despeito de encerrar um fórum de debate apartado dos canais políticos ordinários.

Refutando a ideia de controle de constitucionalidade, Jeremy Waldron ${ }^{267}$ entende que não há motivos suficientes que permitam concluir que a atuação da Corte coloque a democracia em uma melhor situação e vença problemas sensíveis quanto a desacordos que pautam a imensa maioria das escolhas políticas - ainda que em sede de direitos fundamentais. A existência de desacordos seria idiossincrática a qualquer sociedade, e a transferência da decisão a um órgão tão restrito quanto pouco representativo em verdade militaria em desfavor das premissas do jogo democrático, que envolvem a necessidade da prevalência da vontade da maioria. O controle de constitucionalidade, assim, não se justificaria do ponto de vista substancial, no sentido de que seria uma seara mais adequada para tomadas de decisões dentro do jogo democrático. Do mesmo modo, argumenta que a atuação dos Tribunais Constitucionais pauta-se, igualmente, na regra da maioria simples a decisão vencedora é aquela que conta com o maior número de votos dos membros da Corte -, razão pela qual não haveria que se falar em uma atuação verdadeiramente contramajoritária. ${ }^{268}$ Existindo sempre dissenso quanto às escolhas possíveis e adequadas e sobre a forma de se avaliar tais escolhas frente aos compromissos constitucionais, e

${ }^{266}$ TAVARES, André Ramos. Tribunal e jurisdição constitucional, op. cit., p. 72.

${ }^{267}$ WALDRON, Jeremy, op. cit., pp. 1359 e ss. Para uma análise a respeito da teoria de Jeremy Waldron a respeito do controle de constitucionalidade, ver: MENDES, Conrado Hübner. Controle de constitucionalidade e democracia, op. cit., pp. 81 e ss.

${ }^{268}$ Consoante esclarece Conrado Hüber Mendes: “A Suprema Corte não seria, para Waldron, uma instituição contra-majoritária. Ao contrário, toma suas decisões por maioria, ou seja, com base na maioria simples. Além disso, apesar de os juízes apoiarem suas decisões em longos arrazoados, a qualidade a decisão não tem impacto nenhum no peso de seu voto. Não vale mais por ter feito uma pesquisa erudita, por ter um argumento coerente; será somente mais um voto a se somar aos outros. O voto mais eloqüente conta a mesma coisa que um medíocre para a decisão final. (...) [I]ndependentemente da qualidade ou mérito substantivo da decisão, a maioria simples continua a vencer." MENDES, Conrado Hübner. Controle de constitucionalidade $e$ democracia, op. cit., p. 102. 
pautando-se a democracia na ideia da prevalência da maioria, seria mais adequado reforçar o próprio processo político que relegar decisões a outro órgão que, ao fim e ao cabo, não oferece maiores garantias a respeito da retidão de suas escolhas.

John Hart Ely ${ }^{269}$ também parte da premissa de que há no controle de constitucionalidade um elemento de negação à premissa democrática do autogoverno da maioria - no sentido de que o povo deve ter a prerrogativa de escolher as políticas sob as quais se desenvolve a sociedade. Afirma, assim, que o grande problema relativo à revisão judicial reside na ideia de que um corpo não eleito e que não conta com responsabilidade política significativa acaba por indicar aos representantes do povo a maneira pela qual devem governar, o que no mais das vezes envolve afirmar que eles não podem governar como gostariam. ${ }^{270}$ Diferencia, nesse contexto, a atuação judicial em casos não constitucionais da atuação em casos constitucionais, concluindo que a problemática, nos últimos, decorre de que a decisão proferida não está sujeita a qualquer "correção" por meio do processo legiferante ordinário. $\mathrm{O}$ autor desenvolve $\mathrm{e}^{271}$, a partir da famosa nota de rodapé n. 4 do caso United States vs. Carolene $e^{272}$, a ideia de um controle de constitucionalidade que não se baseia em um viés substantivo, no sentido de que caberia às Cortes definir os verdadeiros valores constitucionais e a forma pela qual podem ser aplicados e interpretados, mas sim em um caráter procedimental, competindo à Corte controlar o próprio processo político decisório - seara na qual tais escolhas devem ser feitas -, averiguando se ele garante a abertura dos canais de participação e não tolhe do processo decisório minorias que, ainda que ao final sejam vencidas, devem ter direito de se fazer representar e de participar do debate. ${ }^{273}$

\footnotetext{
${ }^{269}$ ELY, John Hart. Democracy and distrust: a theory of judicial review. Cambridge: Harvard University Press, 1980.

${ }^{270}$ Idem, ibidem, pp. 4-5.

${ }^{271}$ Idem, ibidem, pp. 73 e ss.

${ }^{272}$ Segundo Oscar Vilhena Vieira, analisando a obra de John Ely Hart: "Referida nota aponta em primeiro lugar que os juízes devem sempre fazer uma leitura da Constituição muito próxima ao texto. Em segundo lugar, avaliar se os canais de participação política que levaram à elaboração da norma impugnada em face do Tribunal estavam abertos. Terceiro, se o processo político tem discriminado grupos minoritários insulares, ou se seus resultados terão impacto discriminatório sobre esses mesmos grupos, levando à fragilização do processo democrático." VIEIRA, Oscar Vilhena. A Constituição e sua reserva de Justiça (um ensaio sobre os limites materiais do poder de reforma), op. cit., p. 215.

${ }^{273}$ Ronald Dworkin aponta, nesse sentido, as proposições sobre as quais pauta-se a teoria de Ely: "(1) A revisão judicial deve ter em vista o processo da legislação, não o resultado isolado desse processo. (2) Ela deve avaliar esse processo segundo o padrão da democracia. (3) A revisão baseada no processo, portanto, é compatível com a democracia, ao passo que a revisão baseada na substância, que tem em vista os resultados, é antagônica a elas. (4) O Tribunal, portanto, erra quando cita um valor substantivo putativamente fundamental para justificar a revogação de uma decisão legislativa." DWORKIN, Ronald. Uma questão de princípio. São Paulo: Martins Fontes, 2005, p. 81
} 
A teoria de Ely é alvo de críticas ${ }^{274}$, em especial porque ao rechaçar uma concepção substantiva de revisão judicial e ao apregoar que o controle de constitucionalidade se atenha ao processo legiferante, ignora que a Corte deve fazer juízos morais, éticos e normativos a respeito de qual é a melhor forma de se tutelar os preceitos democráticos no processo político. Não haveria como evitar, portanto, algum juízo substantivo por parte do Tribunal. ${ }^{275}$

A despeito disso, o posicionamento de Ely permite a problematização a respeito da seara adequada para a tomada de decisões políticas substantivas e para a eleição de políticas fundamentais, na medida em que propõe uma limitação às possibilidades de intervenção da jurisdição constitucional dentro de um conceito que visa a garantir a primazia dos canais ordinários de legiferação.

No outro extremo, e defendendo uma visão substantiva do controle de constitucionalidade, Ronald Dworkin apresenta argumentos em favor da completa embora não exclusiva - deferência de competência revisional ao Judiciário. ${ }^{276}$ Dworkin desenvolve a ideia de que os indivíduos possuem direitos morais contra o Estado além daqueles que o ordenamento garante de maneira expressa, e que se pautam, sobretudo, na ideia de que todos devem ser tratados como iguais pelo governo. ${ }^{277} \mathrm{~A}$ proteção e a efetivação de tais direitos, por sua vez, envolvem a tomada de decisões de princípio, em oposição a decisões de política - isto é, “decisões sobre que direitos as pessoas têm em nosso sistema constitucional, não decisões sobre como se promove melhor o bem-estar geral" 278 -, que muitas vezes não são adequadamente alocadas no processo decisório político-majoritário. Ademais, entende serem fracas as objeções que sustentam que o

\footnotetext{
${ }^{274}$ Cf. VIEIRA, Oscar Vilhena. A Constituição e sua reserva de Justiça (um ensaio sobre os limites materiais do poder de reforma), op. cit., pp. 218 e ss.

${ }^{275}$ Nesse sentido, contesta Ronald Dworkin: "O argumento de Ely de que o Tribunal pode evitar questões de substância apoiando suas decisões na melhor concepção de democracia seria então auto-anulador. Pelo menos uma vez Ely reconhece (como deve e tem de reconhecer) que o Tribunal precisa definir qual é para si a melhor concepção de democracia e, assim, fazer novos julgamentos políticos de algum tipo. Ele tem apenas dois argumentos a favor do programa que descreve: que os tribunais estão bastante habilitados para fazer julgamentos sobre o processo justo, mas muito mal habilitados para fazer julgamentos políticos substantivos, e que julgamentos feitos em tribunal sobre processo são compatíveis com a democracia, ao passo que julgamentos feitos em tribunal sobre substância não são. Se o Tribunal não pode fazer julgamentos sobre processo que Ely recomenda sem fazer os julgamentos sobre substância que ele condena, então sua teria será distorcida por seus próprios argumentos." DWORKIN, Ronald. Uma questão de princípio, op. cit., pp. 8485.

${ }^{276}$ Para uma análise a respeito do posicionamento de Dworkin sobre o tema, ver: MENDES, Conrado Hübner. Controle de constitucionalidade e democracia, op. cit., pp. 33 e ss.

${ }^{277}$ Idem, ibidem, pp. 100-103; e DWORKIN, Ronald. Levando os direitos a sério. São Paulo: WMF Martins Fontes, 2010, pp. 205 e ss.

${ }^{278}$ DWORKIN, Ronald. Uma questão de princípio, op. cit., p. 101.
} 
Judiciário não deveria participar na conformação substantiva do ordenamento jurídico por lhe faltar representatividade democrática - em razão do que seria mais justo deixar a tomada de decisões sensíveis às instituições efetivamente representativas, que expressariam melhor a vontade da maioria. Conclui, nesse sentido, que esse raciocínio

\begin{abstract}
ignora o fato de que as decisões a respeito dos direitos contra a maioria não questões que devam, por razões de equidade, ser deixadas a cargo da maioria. $\mathrm{O}$ constitucionalismo - a teoria segundo a qual os poderes da maioria devem ser limitados para que se protejam os direitos individuais - pode ser uma teoria política boa ou má, mas foi adotada pelos Estados Unidos, e não parece justo ou coerente permitir que a maioria julgue em causa própria. ${ }^{279}$
\end{abstract}

Com isso, sustenta o autor que o controle de constitucionalidade, para além de permitir uma tutela mais efetiva dos direitos morais dos indivíduos perante o Estado garantindo inclusive uma proteção contra escolhas indevidas das maiorias -, faz com o que questões fundamentais de moralidade política sejam discutidas e debatidas fora do âmbito do poder político e dentro do fórum do princípio - i.e., relativo à definição dos direitos que as pessoas possuem. Esse processo ocorreria tanto no âmbito dos tribunais como fora dele, com o que haveria o desenvolvimento e o fortalecimento do compromisso democrático. ${ }^{280}$ Aponta Conrado Hübner Mendes, entretanto, que a ideia de Dworkin vai além e apoia-se na premissa de que compete à jurisdição constitucional buscar as respostas corretas aos problemas que lhe são postos. ${ }^{281}$ Sintetizando o pensamento de Dworkin, esclarece que este

\footnotetext{
não se incomoda com o risco de que a Corte erre. Falhas acontecem, e a possibilidade do erro, tanto pelo juiz quanto pelo legislador, é simétrica. A Corte alça a discussão para o plano dos princípios. Importam, antes, o compromisso e a atitude, não a resposta. $\mathrm{O}$ fórum do princípio, para que se proteja da batalha da política cotidiana, compromete-se com a disciplina do argumento.

Numa democracia, é interessante que haja alguma instituição assim, comprometida com o princípio e cobrada por isso. A Corte não se legitima somente quando acerta, mas sempre que explicitamente tente fazê-lo. A essência da integridade constitucional é a atitude hercúlea de encontrar o melhor argumento, que desafia e vence todos os outros, não o consenso sobre a decisão verdadeira num caso concreto. Mesmo que errem, esse ambiente seria louvável. ${ }^{282}$
}

\footnotetext{
${ }^{279}$ DWORKIN, Ronald. Levando os direitos a sério, op. cit., pp. 222-223.

${ }^{280}$ DWORKIN, Ronald. Uma questão de princípio, op. cit., pp. 102-103.

${ }^{281}$ MENDES, Conrado Hübner. Controle de constitucionalidade e democracia, op. cit., p. 78.

${ }^{282}$ Idem, ibidem, p. 79.
} 
Os posicionamentos acima expostos de maneira muito sintética permitem, sobretudo, desenvolver o debate a respeito da relevância e do papel da função de controle do Poder Judiciário dentro do contexto das regras do jogo democrático, no sentido de buscar uma compatibilização que justifique um maior ou menor grau de ingerência judicial.

O maior embate se dá pelo fato de que a democracia envolve tanto um elemento procedimental, no sentido de que compete à maioria estabelecer - por intermédio representantes eleitos que possuam responsiveness e accountability - as políticas que regem a sociedade, quanto um elemento substantivo, que impõe o reconhecimento da imperatividade da proteção dos direitos das minorias.

A jurisdição constitucional busca sua legitimidade, em grande medida, nesse viés substantivo da democracia ${ }^{283}$, sob o fundamento de que o princípio da maioria empregado nos canais políticos de produção normativa pode se desviar dos compromissos constitucionais. A proteção das minorias e a tutela da Constituição contra miopias do grupo dominante se prestariam, assim, a fortalecer a própria democracia. Esse raciocínio possui grande parcela de verdade. Ao se proceder dessa forma, entretanto, corre-se o risco de arrefecer a outra faceta democrática, com a transferência de poder decisório para um órgão que não possui representatividade democrática direta e não presta contas de suas escolhas. Nesse aspecto, consoante bem pondera Conrado Hübner Mendes, o argumento de Waldron permanece especialmente provocativo: “[q]uando do desacordo irresoluto, não há

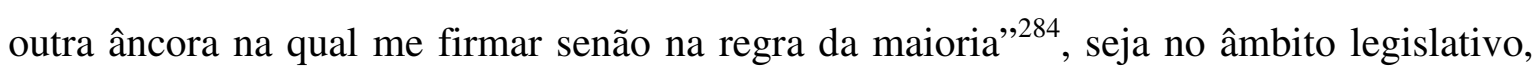
seja no âmbito de uma Corte Constitucional.

O fato de não haver mecanismos que permitam afirmar, de maneira objetiva e substantiva, que a ponderação do Tribunal Constitucional seja mais adequada que aquela feita pela maioria política, não retira, contudo, a importância do controle de constitucionalidade para o fortalecimento da democracia. A jurisdição constitucional, em verdade, permite o aprimoramento das premissas democráticas. ${ }^{285}$

\footnotetext{
${ }^{283}$ MENDES, Conrado Hübner. Controle de constitucionalidade e democracia, op. cit., p. 84.

${ }^{284}$ Idem, ibidem, p. 181.

${ }^{285}$ Segundo Paulo Hamilton Siqueira Junior: “[A] Jurisdição Constitucional é um instrumento de controle político, sendo certo que sua existência contribui para o aprimoramento da democracia. A Jurisdição Constitucional se coaduna perfeitamente com o Estado Democrático e Social de Direito, na medida em que se torna instrumento eficaz para compatibilizar preceitos do Estado Liberal com os do Estado Social. A Constituição tem essa função. Logo, a existência de um órgão com a finalidade da implementação e da guarda dos preceitos constitucionais, sem a presença das paixões políticas, é indispensável. (...) A
} 
A despeito de não se poder dizer que a jurisdição constitucional leva sempre e necessariamente a uma melhor decisão, não há como se negar que ela efetivamente submete as escolhas tomadas pelos atores políticos a um novo crivo, em um contexto menos politizado e em que se exige um maior ônus argumentativo na análise da dimensão jurídica da Constituição. E o argumento de Dworkin defere especial atenção a esse fator. Se por um lado o controle de constitucionalidade pode transparecer mera sobreposição de escolhas a respeito de questões controversas - e em relação às quais sempre haverá desacordo -, por outro parece inegável que este mecanismo fortalece a discussão jurídica e política a respeito das possibilidades admitidas em um sistema constitucional, ao mesmo tempo em que oferece uma via de proteção contra possíveis arbitrariedades da maioria política.

Consoante conclui Oscar Vilhena Vieira, talvez neste último elemento resida a maior importância da revisão judicial no contexto democrático, ao permitir que pela fundamentação de suas decisões as Cortes fomentem uma discussão pública a respeito do alcance e dos limites das disposições constitucionais e promovam a proteção da reserva de justiça da Constituição. ${ }^{286}$ Menos que garantir a resposta correta, portanto, o controle de constitucionalidade se insere no contexto democrático ao aumentar o diálogo interinstitucional e ao exigir maiores justificativas às escolhas das maiorias.

A harmonia entre esses fatores é condicionada, especialmente, pela política da Corte e pela previsão de regras que delimitem melhor sua atuação. Entre os extremos da autocontenção e do ativismo judicial reside uma ampla gama de possibilidades de cotejo entre a proteção de um viés mais procedimental ou mais substantivo de democracia, cujo ponto de equilíbrio acaba por ser definido pelo próprio Tribunal.

Muito embora os contornos institucionais relativos às competências dos Poderes estatais possam assumir diversas nuances, pode acontecer (como ocorre no Brasil) que, no contexto do diálogo interinstitucional, à decisão proferida pela Corte Constitucional se

\footnotetext{
democracia sobrevive e se legitima pela resolução dos conflitos e controle do poder, aspectos que estão ligados à Jurisdição Constitucional que produz o consenso social, outro pilar democrático. A presença do conflito afeta o sistema democrático. A resolução das alterações sociais reafirmam a democracia e a paz social. A Jurisdição Constitucional é consectário lógico da democracia, na medida em que o controle caminha ao lado desse regime. O desenvolvimento da democracia é proporcional ao sistema de controle (...)." SIQUEIRA JUNIOR, Paulo Hamilton. "Jurisdição Constitucional Democrática", in: Revista do Curso de Direito do Centro Universitário das Faculdades Metropolitanas Unidas, v.20, n.28 (2006) p. 82.

${ }^{286}$ VIEIRA, Oscar Vilhena. A Constituição e sua reserva de Justiça (um ensaio sobre os limites materiais do poder de reforma), op. cit., pp. 268-270.
} 
atribua um peso maior, como se realmente resultasse da atuação da última instância responsável pela guarda e efetividade da Constituição.

Em especial por lhe competir realizar o controle das emendas à Constituição, o equilíbrio na compatibilização entre a revisão judicial e os princípios democráticos exige especial cautela do Supremo Tribunal Federal. A possibilidade, que o ordenamento lhe dá, de imunizar sua ratio decidendi através do discurso das cláusulas pétreas e de controlar suas próprias competências - o que lhe permite, por exemplo que defina os casos em que pode a Corte suprir omissões do legislador mediante prolação de decisões com efeitos aditivos - atribui inegável poder de sobrepor, de maneira praticamente definitiva, suas escolhas políticas (ainda que revestidas no discurso jurídico) àquelas resultantes do processo legiferante. E isso se desenvolve mesmo em um contexto normativo em que, em tese, o legislador não está vinculado às ponderações da jurisdição constitucional.

Conquanto seja louvável a intenção jurisprudencial de buscar aprimorar o conteúdo de justiça das normas do ordenamento e de garantir uma efetiva proteção a minorias alijadas do processo decisório, não se pode olvidar que a democracia também envolve o respeito e a proteção das escolhas das maiorias, ao menos quando não se mostrem patentemente conflitantes com preceitos constitucionais. O elemento crítico reside, assim, na prudência da análise de se estar diante de clara inconstitucionalidade ou diante do simples desejo de se reformar uma política, por decisão pretoriana, pela imposição de outra visão política que, na concepção do Tribunal, pareça mais garantista ou mais condizente com os ditames constitucionais. Relegar a busca do ponto ótimo do ordenamento e de sua reserva de justiça à alta instância Judicial deve enfrentar, necessariamente, a questão sobre a legitimidade desse órgão para representar os anseios sociais.

Se duas opções são defensáveis e apresentam-se plausíveis dentro de um diálogo constitucional, deve-se exigir um maior esforço argumentativo da Corte para que ela possa justificar a sobreposição de sua valoração àquela da maioria. $\mathrm{O}$ argumento da melhor adequação, para este propósito, pode ser tão subjetivo quanto perigoso.

O controle de constitucionalidade exercido pelo Supremo Tribunal Federal inegavelmente se insere na realidade democrática brasileira da Constituição de 1988. O desenvolvimento da relação entre Corte e promoção da democracia depende, entretanto, da fixação de parâmetros e limites mais claros ao exercício da função de fiscalização, sem os quais se corre o risco do estigma de um ativismo exacerbado que desconsidera ao extremo 
o direito da maioria em estabelecer as decisões fundamentais do Estado e as políticas delas decorrentes. O direito de escolha da maioria certamente não lhe permite desrespeitar a reserva de justiça da Constituição, violar os pré-compromissos e, consequentemente, negar às minorias o gozo de direitos fundamentais positivados. O mérito e o desafio da atuação do Supremo Tribunal Federal estão em identificar esses pontos de conflito e readequar as escolhas das maiorias (seja atuando como fiscal negativo ou proferindo decisões com efeitos aditivos). Não se pode sob esse pretexto, contudo, ignorar que o desacordo é ínsito às escolhas políticas, e que deve ser assegurada à maioria uma grande autonomia na tomada de posicionamentos a esse respeito. 


\section{CONCLUSÃO}

As diversas transformações por que passaram os paradigmas do Estado de Direito ao longo do século passado atribuíram uma nova dimensão às funções exercidas pelo Poder Judiciário. O anseio de consolidação de sociedades mais democráticas foi acompanhado, de um lado, pela ampliação do âmbito de incidência das Constituições, que passam a se preocupar com a positivação de princípios, direitos e garantias que sirvam de baliza à atividade estatal, e, de outro lado, pela sedimentação de sistemas de controle de constitucionalidade.

A institucionalização de mecanismos de controle normativo em favor do Judiciário decorre de escolha dos atores políticos que desenham o arranjo constitucional, seja no intuito de sinalizar um maior comprometimento com a supremacia da Constituição e com as limitações que ela impõe à atividade estatal, seja no anseio de garantir novos canais de legitimação ou de contestação de políticas adotadas por maiorias, ou ainda mesmo para retirar do âmbito político - em favor da seara judicial - uma série de questões políticas sensíveis sobre as quais se torna praticamente impossível o consenso. Não obstante, uma vez iniciado o processo de judicialização da política, deflagra-se uma rápida expansão da influência deste Poder no contexto político-decisório.

Essa expansão decorre, em grande parte, das novas responsabilidades assumidas pelo Judiciário, e em especial pelas Cortes Constitucionais, no anseio de garantir a efetividade dos preceitos constitucionais. Torna-se, com isso, codemandado, junto com o Legislativo e com o Executivo, na consecução das metas impostas ao Estado na promoção de uma sociedade mais justa. Passa a cumprir tal desígnio mediante o exercício de uma fiscalização mais intensa do processo de tomada de decisões políticas.

Os sistemas de revisão judicial surgem, por excelência, para resolver problemas institucionais, ligados aos limites de atuação dos órgãos e entes estatais, por exemplo. $\mathrm{O}$ exercício do controle de constitucionalidade, certamente, sempre acarreta uma ingerência política por parte do Judiciário e sempre reflete no processo de escolhas políticas. Ainda assim, enquanto se esteja no âmbito de conflitos dessa natureza, tais efeitos tendem a ser menos sensíveis, haja vista que resolvem problemas estruturais de competência que não refletem diretamente na definição dos direitos que os indivíduos possuem. 
No entanto, uma vez consolidada sua atividade fiscalizatória no âmbito de conflitos institucionais, quando então o Judiciário já se sente confortável no manejo de questões de cunho político, há uma implacável tendência a que este Poder assuma também a incumbência de promover a efetividade de direitos fundamentais constitucionalizados. Sua participação no processo de escolhas feitas pelas maiorias governantes, assim, se desenvolve num ritmo crescente. As Cortes Constitucionais são instadas a fiscalizar o próprio conteúdo do processo legiferante com base em um sem número de ponderações que são admitidas no cotejo entre os mais diversos direitos fundamentais. As minorias e demais grupos que não conseguem fazer valer suas preferências nos canais legislativos ordinários socorrerem-se das instâncias judiciais como forma de contestar as decisões tomadas pela maioria. Nesta seara, a ingerência política do Judiciário tende a ser mais controvertida, na medida em que lhe permite confrontar e sobrepor suas concepções àquelas feitas pelo legislador no tocante à definição do próprio conteúdo essencial de direitos fundamentais.

Conforme se buscou demonstrar, a política institucional do Judiciário - em especial de sua Corte Constitucional - desempenha papel central na definição do nível de ingerência deste Poder. As Cortes oscilam, no mais das vezes, de um posicionamento de autocontenção, especialmente verificável quando do período inicial de sedimentação de sua função de controle, a um posicionamento mais ativista, quando então verdadeiramente transformam o escopo do controle de constitucionalidade. Em primeiro lugar, pelo fato de que no exercício da competência de veto, no sentido de rechaçar do ordenamento normas reputadas inconstitucionais, busca-se impor de maneira mais intensa a leitura que o próprio órgão de controle faz dos preceitos constitucionais, o que aumenta o ônus do Legislativo de justificar suas decisões. Em segundo lugar, em razão de se passar a proferir decisões com efeitos aditivos e/ou substitutivos, seja fixando interpretações que condicionam a aplicação de determinada norma, seja preenchendo vazios normativos deixados pelo legislador. Resta evidenciado, portanto, uma atividade jurisdicional com caráter normativo, que busca readequar e corrigir supostas falhas existentes nas decisões tomadas pelos atores políticos.

No contexto brasileiro, o Supremo Tribunal Federal tornou-se copartícipe do processo político e da definição de políticas nacionais. A ampliação de sua função de controle sob a vigência da Constituição de 1988, bem como o desenvolvimento de uma política institucional mais ativista ao longo da última década fizeram com que o órgão se 
tornasse o fórum por excelência para contestação de decisões políticas fundamentais. Sua intervenção política trilhou, grosso modo, o mesmo caminho acima indicado. De início, sua atuação, no exercício da função de controle, ocupava-se principalmente por questões relativas à separação de Poderes, ao federalismo e ao controle do sistema políticopartidário, quando então assumia um posicionamento mais voltado à autocontenção. Ao longo dos últimos anos, no entanto, sua agenda passou a ser tomada por demandas ligadas à proteção de direitos fundamentais, que não raras vezes demandavam sua atuação em matérias sobre as quais o Legislativo evitava tomar um posicionamento efetivo.

Essa nova agenda, que se somou à anteriormente existente, mudou a própria concepção pela qual o Supremo Tribunal Federal avaliava temas mais tradicionais ligados à conformação do sistema político. A mudança em sua jurisprudência no tocante à questão da fidelidade partidária é exemplo claro disso, tendo a Corte instituído uma nova causa de perda de mandato parlamentar não prevista na Constituição. A discussão a respeito dos limites de sua função de controle é alvo de debates que se repetem nos casos que atraem maior atenção social e midiática. Não obstante, verifica-se que a Corte atualmente entendese legitimada a atuar como "legislador positivo", conforme comumente mencionam os Ministros, especialmente quando se esteja diante de uma omissão legislativa sensível, que tolha o exercício de algum direito fundamental, ou da necessidade de se retificar o âmbito de incidência de uma norma ou limitar as interpretações que admite.

Mais que um participante do processo político decisório, o Supremo Tribunal Federal avoca para si o papel de dar maior efetividade à Constituição, com o que se verifica que busca aprimorar o ordenamento jurídico mediante o exercício do controle de constitucionalidade - o que atenua, é claro, a liberdade de conformação das maiorias governantes. Para tanto, e sendo a própria Corte quem possui competência para definir sua competência para interferir no processo político, estende e amplia livremente o escopo dos mecanismos de controle de constitucionalidade, a exemplo de sua recente jurisprudência que dá novos contornos ao mandado de injunção.

O legislador, em tese, está imune à ratio decidendi exposta em decisões de controle abstrato de constitucionalidade e, assim, pode livremente reinserir no ordenamento uma norma reputada inconstitucional ou outra que se baseie em premissas semelhantes. Não obstante, atos de recalcitrância legislativa são passíveis de novos e sucessivos controles por parte do Judiciário, abrindo espaço para sobreposições de decisões legislativas e judiciais. 
Esse embate se desenvolve dentro do contexto de um diálogo interinstitucional entre Judiciário, Executivo e Legislativo, de modo que o primeiro não atua livre de influência dos demais. Entretanto, o sistema brasileiro parece atribuir prevalência às decisões proferidas pelo Supremo Tribunal Federal, a despeito da mencionada imunidade, em tese, do legislador em relação às razões de decidir apresentadas pela Corte, especialmente em razão de se atribuir ao Supremo Tribunal Federal até mesmo a função de controlar a atividade do Poder Constituinte derivado. Em vista disso, ao manejar a proteção e o resguardo de cláusulas pétreas, que contam com status de superconstitucionalidade, suas decisões acabam por se revestir de um discurso imunizante contra o qual nem mesmo o legislador constitucional pode se desvencilhar sem riscos de submeter-se a novo controle de constitucionalidade. A Corte acaba por esboçar, com isso, argumentos a respeito dos próprios limites últimos admitidos em nosso ordenamento, ampliando com isso os paradigmas de constitucionalidade.

Conforme já se afirmou, o Supremo Tribunal Federal se tornou um dos atores que participam ativamente do processo de escolhas de políticas nacionais. Casos emblemáticos a respeito do abortamento de fetos anencéfalos, da união estável homoafetiva e da utilização de células-tronco em pesquisas científicas mostram que seus membros entendem que faz parte do compromisso do órgão garantir a efetividade de direitos fundamentais, mesmo que para tanto tenha de fazer escolhas em prejuízo daquelas feitas pelo legislador, ou então para suprir aquelas não feitas pelo legislador. Por outro lado, o controle que realiza especialmente no tocante ao nosso sistema político-partidário, a exemplo dos casos relativos à cláusula de desempenho e à fidelidade partidária, mostram que a Corte busca aprimorar as instituições democráticas.

Não obstante, essa atuação, que envolve a anulação, a retificação ou a imposição de políticas por via judicial, deve necessariamente passar pela discussão a respeito da legitimidade do Judiciário para fazer suas ponderações prevalecerem àquelas das maiorias governantes - que, por extensão, representam a maioria da população. Conforme se argumentou neste trabalho, a democracia envolve tanto a prevalência das escolhas feitas pelas maiorias quanto a proteção e o resguardo das minorias contra decisões que firam preceitos constitucionais basilares. A jurisdição constitucional, nesse sentido, deve buscar sua legitimidade num equilíbrio entre esses elementos, de modo a tutelar as prerrogativas da maioria ao mesmo tempo em que resguarda os direitos das minorias. 
A jurisdição constitucional, com isso, impõe uma readequação e uma redefinição no tocante ao compartilhamento da função de tomada de decisões políticas fundamentais. O Supremo Tribunal Federal força sua participação nesse contexto mediante o exercício do controle de constitucionalidade, de modo que a compreensão desse processo deve, sobretudo, levar à melhor definição dos limites de sua função de resguardar a Constituição, para que o anseio da Corte em efetivar uma sociedade mais justa e democrática não abale a própria premissa democrática da necessidade de se manter um equilíbrio entre os Poderes. 


\section{REFERÊNCIAS BIBLIOGRÁFICAS}

ABRAMOVICH, Víctor; AÑON, María José; COURTIS, Christian. Derechos sociales: instrucciones de uso. México: Fontamara, 2003.

AMARAL JÚNIOR, José Levi Mello do (coord.). Estado de Direito e ativismo judicial. São Paulo: Quartier Latin, 2010.

. "Inconstitucionalidade sem parâmetro no Supremo", disponível em:

$<$ http://www.conjur.com.br/2013-dez-29/analise-constitucional-inconstitucionalidade-

parametro-supremo $>$ (último acesso em 02.01.2014).

- "O constitucionalismo", in: FRANCISCO, José Carlos (coord. e coautor). Neoconstitucionalismo e atividade jurisdicional: do passivismo ao ativismo judicial. Belo Horizonte: Del Rey, 2012, pp. 3-16.

" "Sobre a organização de poderes em Montesquieu: comentários ao

Capítulo VI do Livro XI de O Espírito das Leis”, in: Revista dos Tribunais, v. 868 (fev. 2008), pp. 53-68.

ÁVILA, Humberto Bergmann. "Neoconstitucionalismo: entre a 'Ciência do Direito' e o 'Direito da Ciência'”, in: Revista Eletrônica de Direito do Estado, n. 17 (2009), disponível em <http://www.revistas.unifacs.br/index.php/redu/article/download/679/507> (último acesso em 20.10.2013).

BARROSO, Luiz Roberto. "Judicialização, ativismo judicial e legitimidade democrática, disponível em

<http://www.oab.org.br/editora/revista/users/revista/1235066670174218181901.pdf>

(último acesso em 24.11.2013).

BICKEL, Alexander M. The least dangerous branch: the Supreme Court at the bar of politics. $2^{a}$ edição. New Heaven: Yale University Press, 1986.

BITTENCOURT, Carlos Alberto Lúcio. O controle jurisdicional da constitucionalidade das leis. Rio de Janeiro: Forense, 1968. 
CANOTILHO, José Joaquim Gomes; MENDES, Gilmar Ferreira; SARLET, Ingo Wolfgang; STRECK, Lênio Luiz (coords.). Comentários à Constituição do Brasil. São Paulo: Saraiva/Almedina, 2013.

CAPPELLETTI, Mauro. Juízes legisladores?. Porto Alegre: Sergio Antonio Fabris Editor, 1999. The judicial process in comparative perspective. Oxford: Calendon Press, 1989.

CARBONELL, Miguel (ed.). Neoconstitucionalismo(s). $4^{\text {a }}$ edição. Madri: Trotta, 2009.

CASPER, Jonathan D. "The Supreme Court and national policy making", in: The American Political Science Review, v. 70, n. 1 (mar. 1976), pp. 50-63.

DAHL, Robert. "Decision-making in a democracy: the Supreme Court as a national policy-maker" in: Journal of Public Law, n. 6 (1957), pp. 279-295.

DAVID, René. Os grandes sistemas do direito contemporâneo. $3^{\mathrm{a}}$ edição. São Paulo: Martins Fontes, 1996.

DIMOULIS, Dimitri. Positivismo Jurídico: introdução a uma teoria do direito e defesa do pragmatismo jurídico-político. São Paulo: Método, 2006.

DIMOULIS, Dimitri; LUNARDI, Soraya. Curso de processo constitucional: controle de constitucionalidade e remédios constitucionais. São Paulo: Atlas, 2011.

DWORKIN, Ronald. Levando os direitos a sério. São Paulo: WMF Martins Fontes, 2010. . Uma questão de princípio. São Paulo: Martins Fontes, 2005.

EDLIN, Douglas E. "Judicial Review without a Constitution”, in: Polity, v. 38, n. 3 (jul. 2006), pp. 345-368.

ELY, John Hart. Democracy and distrust: a theory of judicial review. Cambridge: Harvard University Press, 1980.

FARIA, José Eduardo Campos de Oliveira (org.). Direitos humanos, direitos sociais e Justiça. São Paulo: Malheiros, 1994. 
" "Introdução: o Judiciário e o desenvolvimento sócio-econômico", in: FARIA, José Eduardo Campos de Oliveira (org.). Direitos humanos, direitos sociais e Justiça. São Paulo: Malheiros, 1994, pp. 11-29.

FAVOREU, Louis. As Cortes Constitucionais. São Paulo: Landy Editora, 2004.

FERRAJOLI, Luigi. "Estado Social y Estado de Derecho", in: ABRAMOVICH, Víctor; AÑON, María José; COURTIS, Christian. Derechos sociales: instrucciones de uso. México: Fontamara, 2003, pp. 11-21.

FERRAZ JÚNIOR, Tércio Sampaio. "O Judiciário frente à divisão de poderes: um princípio em decadência?”, in: Revista USP, n. 21 (mar./mai. 1994), pp. 12-21.

FERRAZ, Anna Candida da Cunha. Processos informais de mudança da Constituição: mutações constitucionais e mutações inconstitucionais. São Paulo: Max Limonad, 1986.

FERREIRA FILHO, Manoel Gonçalves. O Poder Constituinte. $4^{\mathrm{a}}$ edição. São Paulo: Saraiva, 2005.

Do Processo Legislativo. $5^{\text {a }}$ edição. Saraiva: São Paulo, 2002.

- "O Papel Político do Judiciário e suas Implicações", in:

FRANCISCO, José Carlos (coord. e coautor). Neoconstitucionalismo e atividade jurisdicional: do passivismo ao ativismo judicial. Belo Horizonte: Del Rey, 2012, pp. 221241

- "O sistema constitucional brasileiro e as recentes inovações no controle de constitucionalidade (leis $n^{\circ} 9.868$, de 10 de novembro e $n^{\circ} 9.882$, de 3 de dezembro de 1999).”, in: Revista de Direito Administrativo, n. 220 (abr./jun. 2000), pp. 117.

FRANCISCO, José Carlos (coord. e coautor). Neoconstitucionalismo e atividade jurisdicional: do passivismo ao ativismo judicial. Belo Horizonte: Del Rey, 2012.

GINSBURG, Tom. Judicial review in new democracies: constitutional courts in asian cases. Nova York: Cambridge University Press, 2008. 
" "The global spread of constitutional review", in: WHITTINGTON, Keith E.; KELEMEN, R. Daniel; CALDEIRA, Gregory A. (eds.). The Oxford Handbook of Law and Politics. Nova York: Oxford University Press, 2008, pp. 81-98.

GRABER, Mark A. "The nonmajoritarian difficulty: Legislative deference to the Judiciary”, in: Studies in American Political Development, v. 7 (1993), pp. 35-73.

HILBINK, Lisa. “The constituted nature of constituents' interests: historical and ideational factors in judicial empowerment”, in: Political Research Quarterly, v. 62, n. 4 (dez. 2009), pp. 781-797.

HIRSCHL, Ran. "The judicialization of mega-politics and the rise of political courts", in: Annual Review of Political Science, v. 11 (jun. 2008), pp. 93-118.

"The political origins of judicial empowerment through constitutionalization: lessons from Israel's constitutional revolution", in: Comparative Politics, v. 33, n. 3 (2001), pp. 315-335.

Towards juristocracy: the origins and consequences of the new constitutionalism. Cambridge: Harvard University Press, 2004.

KELSEN, Hans. Jurisdição constitucional. São Paulo: Martins Fontes, 2003.

LAFER, Celso. A reconstrução dos direitos humanos: um diálogo com o pensamento de Hannah Arendt. São Paulo: Companhia das Letras, 1988.

LAURENTIIS, Lucas Catib de. "Efeitos do julgamento e coisa julgada em Ações Declaratórias de Constitucionalidade: ativismo judicial não declarado", in: AMARAL JÚNIOR, José Levi Mello do (coord.). Estado de Direito e ativismo judicial. São Paulo: Quartier Latin, 2010.

LEAL, Roger Stiefelmann. "A incorporação das súmulas vinculantes à jurisdição constitucional brasileira: alcance e efetividade em face do regime legal da repercussão geral e da proposta de revisão jurisprudencial sobre a interpretação do art. 52, X, da Constituição", in: Revista de Direito Administrativo, v. 261 (set./dez. 2012), pp. 179-201. O efeito vinculante na jurisdição constitucional. São Paulo:

Saraiva, 2006. 
LOEWENSTEIN, Karl. Teoría de la Constitución. $2^{\mathrm{a}}$ edição. Barcelona: Ediciones Ariel, 1970.

LOPES, José Reinaldo Lima. "Direito subjetivo e direitos sociais: o dilema do Judiciário no Estado Social de Direito”, in: FARIA, José Eduardo Campos de Oliveira (org.). Direitos humanos, direitos sociais e Justiça. São Paulo: Malheiros, 1994, pp. 113-143.

MADISON, James; HAMILTON, Alexander; JAY, John. Os Artigos Federalistas 17871788: edição integral. Rio de Janeiro: Nova Fronteira, 1993.

MARTINS, Leonardo (org.). Cinqüenta anos de jurisprudência do Tribunal Constitucional Federal Alemão. Tradução de Beatriz Henning et al. Montevideo: Konrad Adenauer Stiftung, 2005.

MATTEUCCI, Nicola. Organización del poder y libertad: historia del constitucionalismo moderno. Madri: Trotta, 1998.

MENDES, Conrado Hübner. Controle de constitucionalidade e democracia. Rio de Janeiro: Elsevier, 2008.

Direitos fundamentais, separação de poderes e deliberação. São

Paulo: Saraiva, 2011.

MENDES, Gilmar Ferreira. Direitos fundamentais e controle de constitucionalidade. $2^{\mathrm{a}}$ edição. São Paulo: Celso Bastos Editor, 1999.

Jurisdição constitucional: o controle abstrato de normas no Brasil e na Alemanha. $5^{\text {a }}$ edição. São Paulo: Saraiva, 2005.

MIRANDA, Jorge. Manual de Direito Constitucional. Tomo II. $3^{\text {a }}$ edição. Coimbra: Coimbra, 1996.

MONTESQUIEU, Charles Louis de Secondat, baron de la Brède et de. O espírito das leis, tradução de Fernando Henrique Cardoso e Leôncio Martins Rodrigues. Brasília: UnB, 1995.

MORAES, Alexandre de. Constituição do Brasil interpretada e legislação constitucional. $8^{a}$ edição. São Paulo: Atlas, 2011. 
NEVES, Marcelo. "Constitucionalização simbólica”, in: CANOTILHO, José Joaquim Gomes; MENDES, Gilmar Ferreira; SARLET, Ingo Wolfgang; STRECK, Lênio Luiz (coords.). Comentários à Constituição do Brasil. São Paulo: Saraiva/Almedina, 2013, pp. 67-74.

PEIXOTO, Leonardo Scofano Damasceno. Supremo Tribunal Federal: composição e indicação de seus ministros. Rio de Janeiro: Forense; São Paulo: Método, 2012.

QUEIROZ, Cristina. Interpretação constitucional e poder judicial: sobre a epistemologia da construção constitucional. Coimbra: Coimbra Editora, 2000.

RAMOS, Elival da Silva. Ativismo Judicial: parâmetros dogmáticos. São Paulo: Saraiva, 2010.

. Controle de constitucionalidade no Brasil: perspectivas e evolução. São Paulo: Saraiva, 2010.

SANCHÍS, Luis Pietro. "Neoconstitucionalismo y ponderacion judicial" in: CARBONELL, Miguel (ed.). Neoconstitucionalismo(s). $4^{\circ}$ edição. Madri: Trotta, 2009, pp. $123-158$.

SHAPIRO, Martin. "Judicialization of politics in the United States", in: International Political Science Review, v. 15, n. 2 (abr. 1994), pp. 101-112

SHAPIRO, Martin; STONE SWEET, Alec. On Law Politics and Judicialization, Nova York: Oxford University Press, 2002.

SILVA, José Afonso da. O constitucionalismo brasileiro (evolução institucional). São Paulo: Malheiros, 2011.

SILVA, Roberto Baptista Dias. Manual de Direito Constitucional. Barueri: Manole, 2007.

SILVA, Virgílio Afonso da. "Interpretação Conforme a Constituição: entre a trivialidade e a centralização judicial”, in: Revista Direito GV, v. 2, n.1 (jan./jul. 2006), pp. 191-210

- "O Judiciário e as políticas públicas: entre transformação social e obstáculo à realização dos direitos sociais", in: SOUZA NETO, Cláudio Pereira; SARMENTO, Daniel (coords.). Direitos Sociais: fundamentos, judicialização e direitos 
sociais em espécie. Rio de Janeiro: Lumen Juris, 2008, pp. 587-599.

SIQUEIRA JUNIOR, Paulo Hamilton. "Jurisdição Constitucional Democrática", in: Revista do Curso de Direito do Centro Universitário das Faculdades Metropolitanas Unidas, v. 20, n. 28 (2006) pp. 72-84.

SOUZA NETO, Cláudio Pereira; SARMENTO, Daniel (coords.). Direitos Sociais: fundamentos, judicialização e direitos sociais em espécie. Rio de Janeiro: Lumen Juris, 2008 .

TATE, C. Nael; VALLINDER, Torbjörn (eds.). The Global Expansion of Judicial Power. Nova York: New York University Press, 1995.

TAVARES, André Ramos. Teoria da justiça constitucional. Tese de livre docência. São Paulo: Universidade de São Paulo, 2003.

Tribunal e jurisdição constitucional. São Paulo: Celso Bastos Editor, 1998.

TUSHNET, Mark. "Law and prudence in the law of justiciability: the transformation and disappearance of the political question doctrine", in: North Caroline Law Review, v. 80 (maio 2009), pp. 1203-1236.

The new constitutional order. Princeton: Princeton University Press, 2003.

VIEIRA, Oscar Vilhena. A Constituição e sua reserva de Justiça (um ensaio sobre os limites materiais do poder de reforma). São Paulo: Malheiros, 1999.

Supremo Tribunal Federal: jurisprudência política. São Paulo: Editora Revista dos Tribunais, 1994.

WALDRON, Jeremy. "The core of the case against judicial review", in: The Yale Law Journal, v. 115, n. 6 (2006), pp. 1346-1406.

WHITTINGTON, Keith E.; KELEMEN, R. Daniel; CALDEIRA, Gregory A. (eds.). The Oxford Handbook of Law and Politics. Nova York: Oxford University Press, 2008. 